\title{
Molecular Spin State Switching and Photochromism in the Red and Near Infrared with $\mathrm{Ni}$ (II) Chlorin and $\mathrm{Ni}$ (II) Bacteriochlorin
}

Vanessa Wellm ${ }^{[\mathrm{a}]}$, Christian Näther ${ }^{[\mathrm{b}]}$ and Rainer Herges ${ }^{[\mathrm{a}] *}$

[a] Otto-Diels-Institute of Organic Chemistry, University of Kiel, Otto-Hahn-Platz 4, Kiel D-24118, Germany.

[b] Institute of Inorganic Chemistry, University of Kiel, Max-Eyth-Straße 2, Kiel D-24118, Germany.

*rherges@oc.uni-kiel.de

Table of Contents

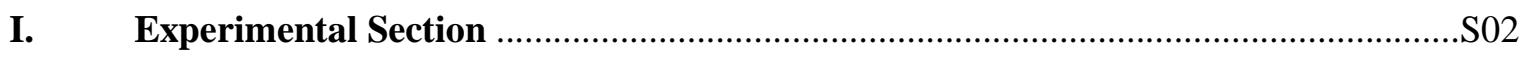

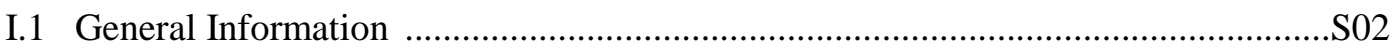

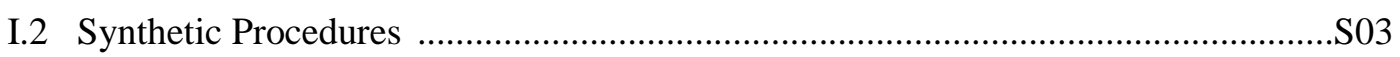

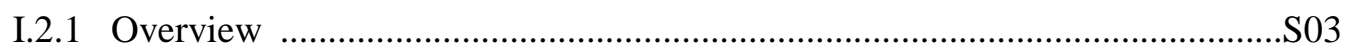

I.2.2 Synthesis of Porphyrin Precursors 4-H $\mathbf{H}_{2}$ and 4-Ni .......................................S06

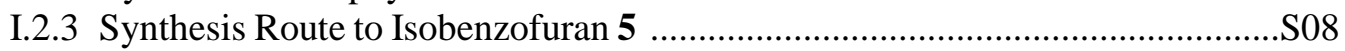

I.2.4 Synthesis of Ni(II) Chlorin Precursors 6a-Ni and 6b-Ni ...................................S09

I.2.5 Synthesis Route to Ni(II) Bacteriochlorin Precursor 7-Ni ...............................S10

I.2.6 Synthesis of Record Players 10a, 10b and 11 ...............................................S14

I.2.7 Synthesis of Dendronized Record Players 12a, 12b and $\mathbf{1 3}$.............................S18

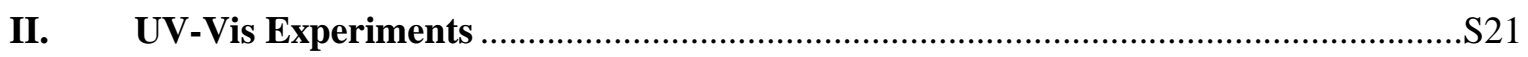

II.1 Extinction Coefficients of Platforms .......................................................................S21

II.2 Coordination-Induced Spin State Switch of Platforms and RPs with

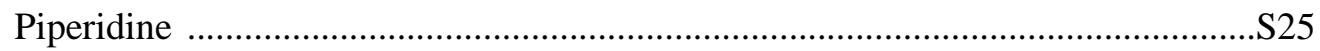

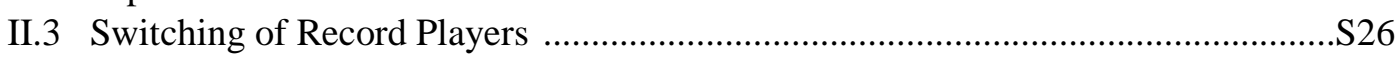

II.4 Long-term Switching Stability of Record Players .............................................S32

II.5 Thermal Half-Lifes of Record Players ................................................................ 34

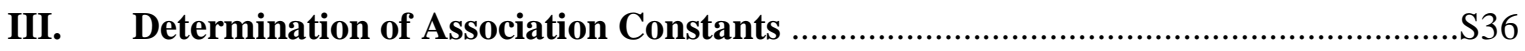

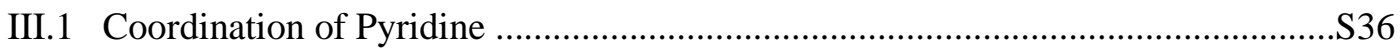

III.2 Coordination of Ethyl Isonicotinate .................................................................S43

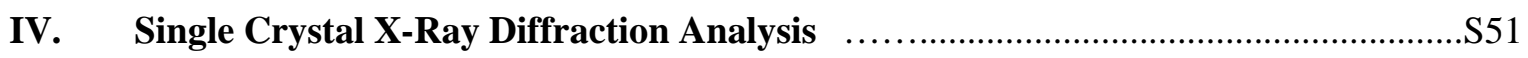

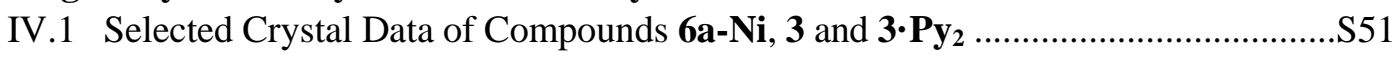

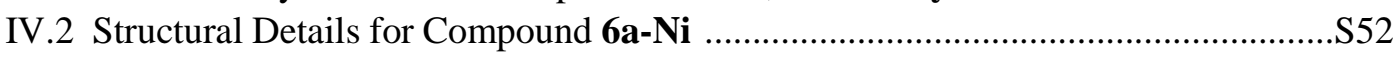

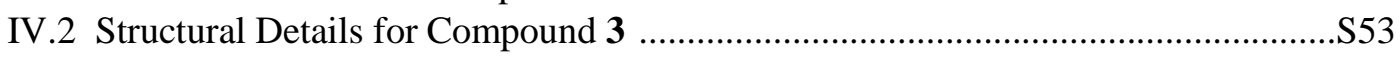

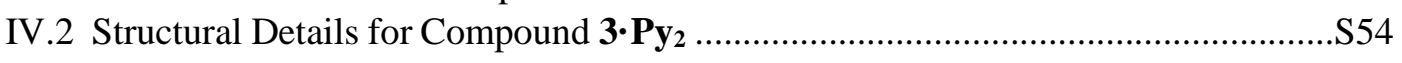

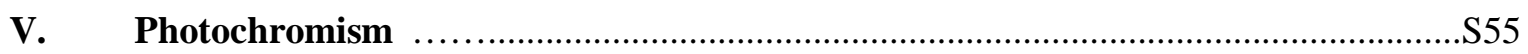

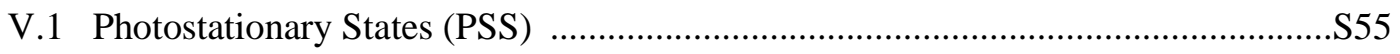

V.2 Switching Efficiencies - Percentage of the Paramagnetic Species .........................S56

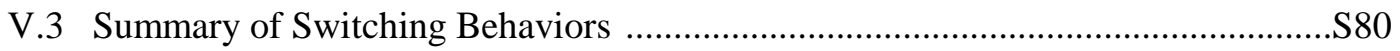

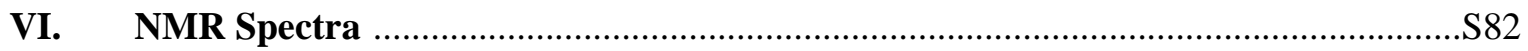

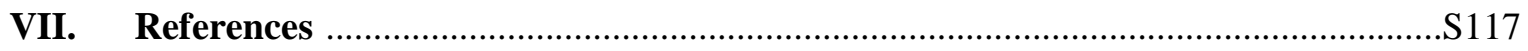




\section{Experimental Section}

\section{I.1 General Information}

Commercially available solvents and starting materials were used as received. Benzene was dried over sodium/benzophenone. Column chromatography was carried out using 0.040-0.063 mm mesh silica gel (Merck). $R_{\mathrm{f}}$ values were determined by thin layer chromatography on Polygram ${ }^{\circledR}$ Sil $\mathrm{G} / \mathrm{UV}_{254}$ (Macherey-Nagel, $0.2 \mathrm{~mm}$ particle size).

NMR spectra were measured in Schott Economic NMR tubes using deuterated solvents (Deutero). The degree of deuteration is given in parentheses. Chemical shifts are calibrated to residual protonated solvent signals $\left({ }^{1} \mathrm{H}: \delta\left(\right.\right.$ acetone- $\left.\mathrm{d}_{6}\right)=2.05 \mathrm{ppm}, \delta\left(\mathrm{CDCl}_{3}\right)=7.26 \mathrm{ppm}, \delta(\mathrm{MeOD})=3.31 \mathrm{ppm}$; deuteration grade $99.8 \%$ ). Reference for ${ }^{19} \mathrm{~F}$ NMR spectra is $\mathrm{CFCl}_{3}$ to which the spectrometer frequency is calibrated. The signal multiplicities are abbreviated as s (singlet), $\mathrm{d}$ (doublet), $\mathrm{t}$ (triplet), q (quartet), quint (quintet), m (multiplet) and br (broad signal). ${ }^{19} \mathrm{~F}$ NMR spectra were measured ${ }^{1} \mathrm{H}$-decoupled. For ${ }^{1} \mathrm{H}$ and ${ }^{13} \mathrm{C}$ NMR signal assignment we performed HSQC and HMBC. Measurements were performed with a Bruker AC $200\left({ }^{1} \mathrm{H}\right.$ NMR: $\left.200 \mathrm{MHz}\right)$, Bruker DRX $500\left({ }^{1} \mathrm{H}\right.$ NMR: $500 \mathrm{MHz},{ }^{13} \mathrm{C}$ NMR: $126 \mathrm{MHz},{ }^{19} \mathrm{~F}$ NMR: $470 \mathrm{MHz},{ }^{11} \mathrm{~B}$ NMR: $\left.160 \mathrm{MHz}\right)$ and Bruker AV $600\left({ }^{1} \mathrm{H}\right.$ NMR: $600 \mathrm{MHz},{ }^{13} \mathrm{C}$ NMR: $151 \mathrm{MHz}$ ). For datasets of record player 10a, 10b, 11, 12a and 12b trifluoroacetic acid-d (TFAd, 10-20 $\mu \mathrm{L}$ ) was added to the deuterated solvent to suppress intermolecular coordination.

The electro spray ionization (ESI) high resolution (HR) mass spectra were measured with a Q Exactive Plus mass spectrometer provided by Thermo Scientific.

Infrared spectra were recorded on a Perkin-Elmer ATR spectrometer with a Golden-Gate-DiamondATR A531-G for neat samples. Signal intensities were abbreviated with w (weak), m (medium), s (strong) and vs (very strong). Broad signals are additionally labeled with br.

UV-visible absorption spectra were recorded on a PerkinElmer Lambda 650 spectrophotometer using quartz cells of $1 \mathrm{~cm}$ path length.

Irradiation experiments were performed with LED light sources provided by Sahlmann Photochemical Solutions. The red LED light sources (620 and $720 \mathrm{~nm}$ ) were built in-house. The light intensities in $1 \mathrm{~cm}$ distance to the light source were measured:

\begin{tabular}{|c|c|c|c|c|c|}
\hline Light source & $\begin{array}{c}620 \mathrm{~nm} \\
(3 \mathrm{LEDs})\end{array}$ & $\begin{array}{c}720 \mathrm{~nm} \\
(4 \mathrm{LEDs})\end{array}$ & $\begin{array}{c}420 \mathrm{~nm} \\
(4 \cdot 3 \mathrm{LEDs})\end{array}$ & $\begin{array}{c}505 \mathrm{~nm} \\
(4 \cdot 3 \mathrm{LEDs})\end{array}$ & $\begin{array}{c}385 \mathrm{~nm} \\
(4 \cdot 3 \mathrm{LEDs})\end{array}$ \\
\hline Light intensity [mW] & 40 & 70 & $4 \cdot 30=120$ & $4 \cdot 30=120$ & $4 \cdot 40=160$ \\
\hline
\end{tabular}

No melting points were measured because retro Diels Alder reaction already occurs over $50{ }^{\circ} \mathrm{C}$.

For ultrafiltration a glass cell of Merck Millipore with an Ultracel ${ }^{\circledR}$ regenerated cellulose membrane (cut-off: $1000 \mathrm{~g} / \mathrm{mol}$ ) was used. 


\section{I.2 Synthetic Procedures}

\section{I.2.1 Overview}

First, for the determination of association constants of the coordination of different pyridine derivatives the chlorin and bacteriochlorin platforms 2 and 3 (Fig. S1) were synthesized using a procedure of PETERS et al. ${ }^{1}$ The association constants were compared with the already known coordination of pyridine to $\mathrm{Ni}(\mathrm{II})$ porphyrin $\mathbf{1}$.
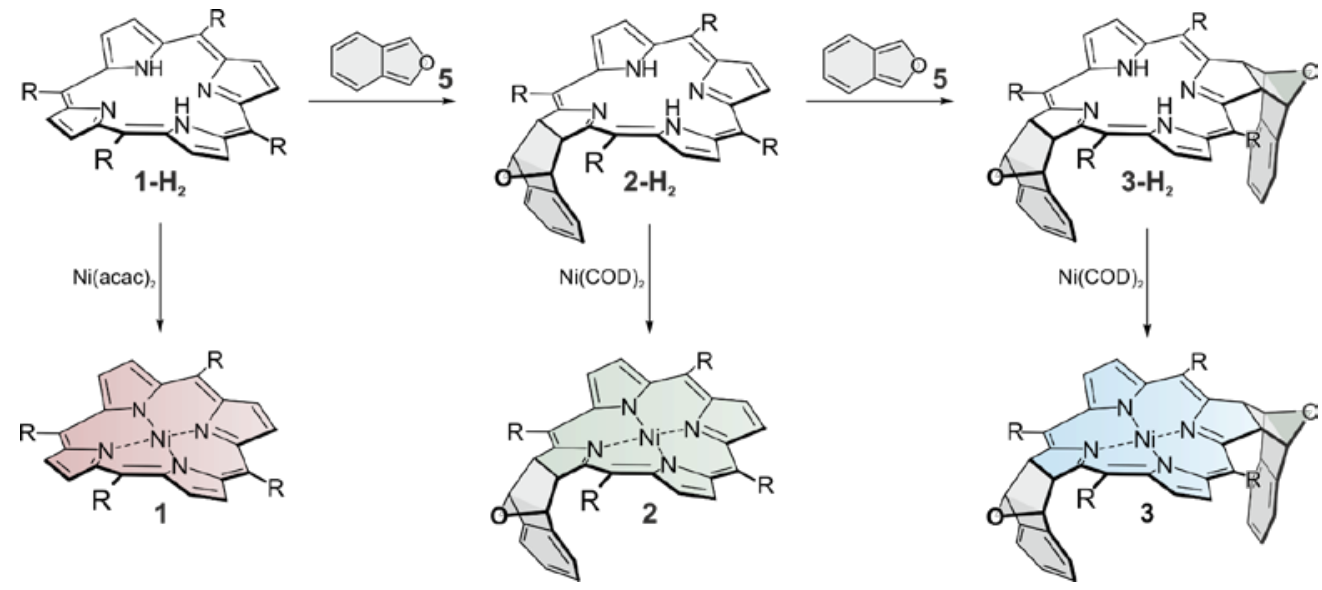

Fig. S1 Synthesis of Ni(II) platforms 1, 2 and $3\left(\mathrm{R}=\mathrm{C}_{6} \mathrm{~F}_{5}\right)$.

The Ni(II) porphyrin precursors $\mathbf{4}$ and $\mathbf{4}-\mathbf{H}_{2}$ were synthesized using the method of Heitmann et al. ${ }^{2}$ Starting from these compounds $\mathrm{Ni}(\mathrm{II})$ chlorins $\mathbf{6 a}-\mathbf{N i}$ and $\mathbf{6 b}-\mathbf{N i}$ and $\mathrm{Ni}(\mathrm{II})$ bacteriochlorin 7-Ni are prepared using a Diels Alder reaction and metal insertion referring to procedures of PETERS et al. ${ }^{1,3}$ Isobenzofuran 5 was synthesized based on publications of Naito $^{4}$ and Arendt $^{5}$ et al. summarized in a publication of Peters et al. ${ }^{6}$ Suzuki cross coupling reactions to record player 10a, 10b and $\mathbf{1 1}$ are derived from a method of DoMMASCHK et al. ${ }^{7}$ The azopyridine switching unit $\mathbf{9}$ was prepared according to previously published procedures. ${ }^{7}$ Fig. S2 and S3 show the corresponding reaction schemes. 

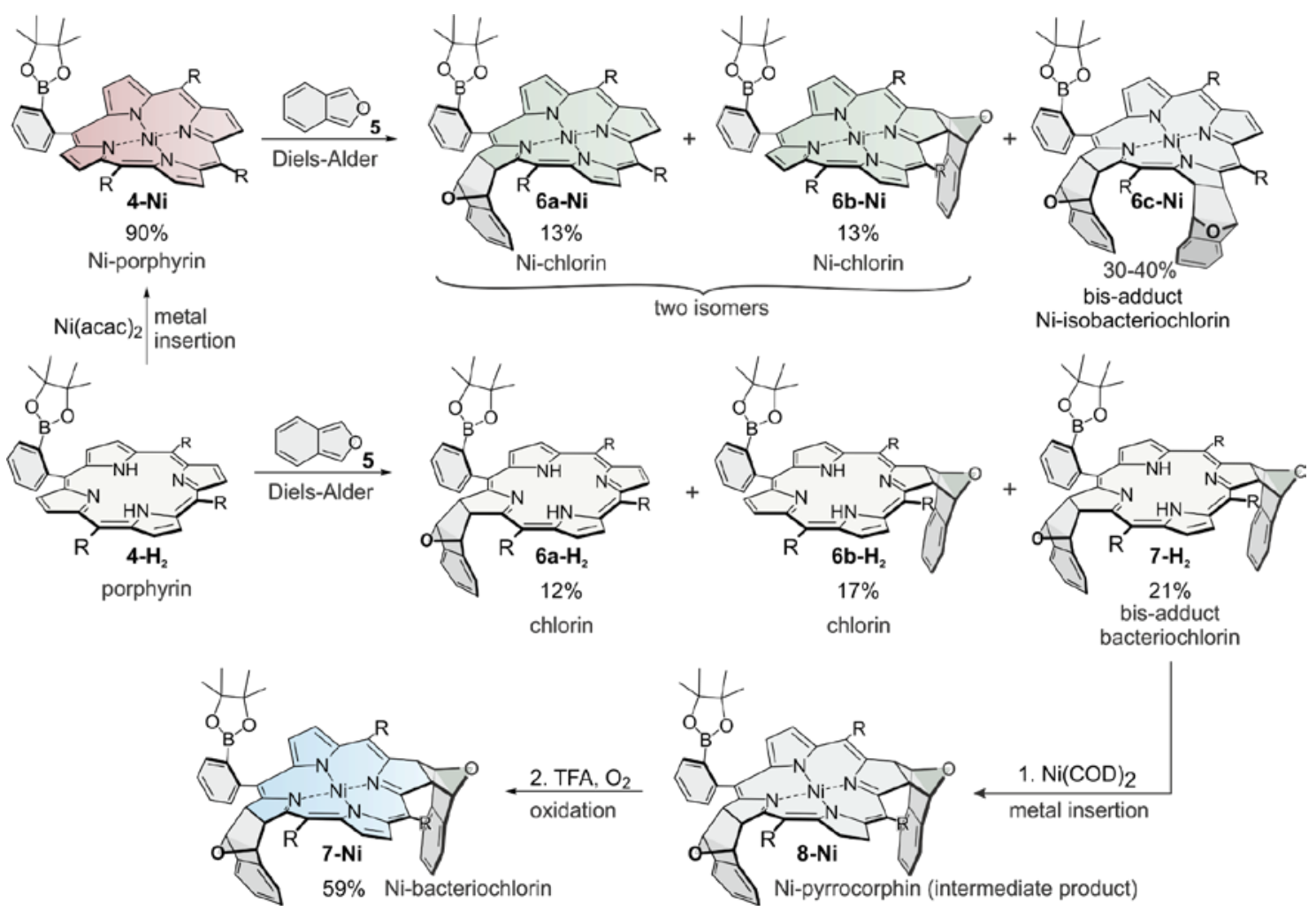

Fig. S2 Synthesis of $\mathrm{Ni(II)}$ chlorin and $\mathrm{Ni(II)}$ bacteriochlorin platforms $\mathbf{6 a - N i}, \mathbf{6 b}-\mathbf{N i}$ and 7-Ni $\left(\mathrm{R}=\mathrm{C}_{6} \mathrm{~F}_{5}\right)$.
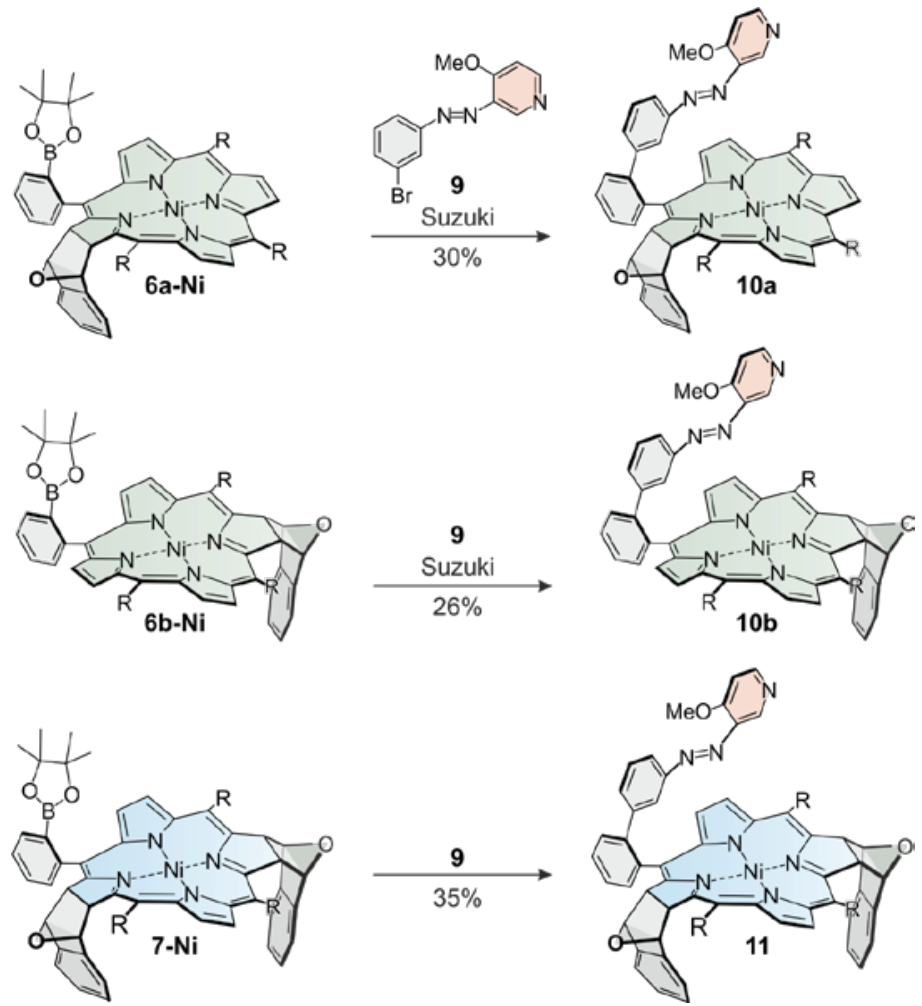

Fig. S3 Suzuki cross coupling reactions to record player $\mathbf{1 0 a}, \mathbf{1 0 b}$ and $\mathbf{1 1}\left(\mathrm{R}=\mathrm{C}_{6} \mathrm{~F}_{5}\right)$. 
Glycerols of the second generation [G2.0]-OH were synthesized using a procedure of HAAG et al. ${ }^{8}$ and were connected to the record player based on a publication of DOMMASCHK et al. ${ }^{9}$ The reaction scheme is shown in Fig. S4.
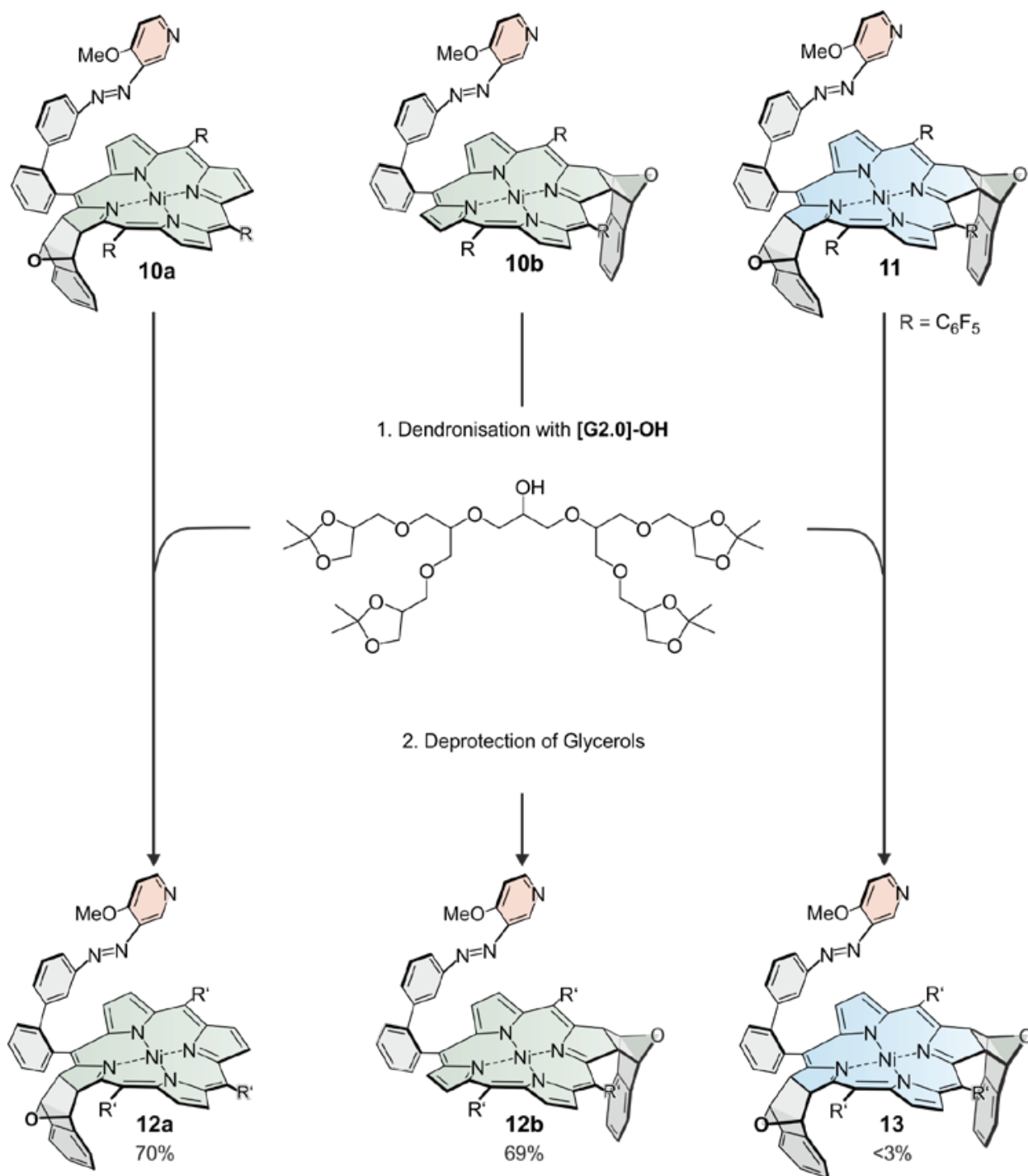

1. Dendronisation with [G2.0]-OH<smiles>CC1(C)OCC(COCC(COCC2COC(C)(C)O2)OCC(O)COC(COCC2COC(C)(C)O2)COCC2COC(C)(C)O2)O1</smiles>

2. Deprotection of Glycerols
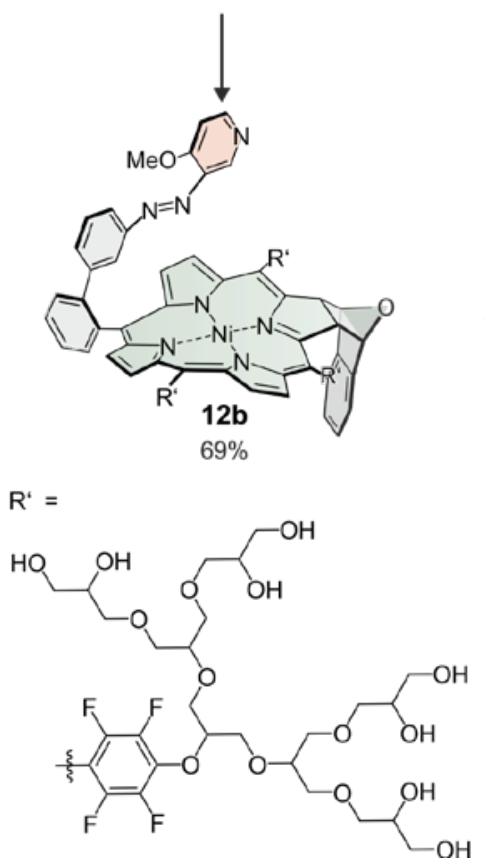

Fig. S4 Synthesis of dendronized record players 12a, 12b and 13. 


\section{I.2.2 Synthesis of Porphyrin Precursors 4-H2 and 4-Ni}

Synthesis of 5-(Phenyl-2'-(boronic acid pinacol ester))-10,15,20-tris(pentafluorophenyl)porphyrin $\left(4-\mathrm{H}_{2}\right)$

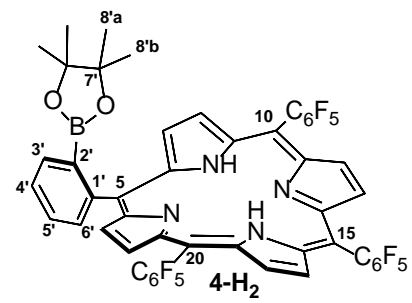

Pentafluorobenzaldehyde ( $910 \mu \mathrm{L}, 1.48 \mathrm{~g}, 7.75 \mathrm{mmol}$ ), 2-formylphenylboronic acid pinacol ester (560 $\mu \mathrm{L}, 2.54 \mathrm{mmol})$ and borontrifluoride diethylester etherate $(0.15 \mathrm{~mL}, 1.18 \mathrm{mmol})$ were dissolved in degassed dichloromethane ( $400 \mathrm{~mL})$. Freshly distilled pyrrol $(700 \mu \mathrm{L}, 10.1 \mathrm{mmol})$ was added. The reaction mixture was stirred $21 \mathrm{~h}$ at $37^{\circ} \mathrm{C}$ in an oil bath. $p$-Chloranil (2.24 g, $\left.9.11 \mathrm{mmol}\right)$ was added and stirring was continued for $23 \mathrm{~h}$ at $37{ }^{\circ} \mathrm{C}$ in an oil bath. The reaction mixture was filtered over diatomaceous earth and the solvent was removed under reduced pressure. The crude product was purified by column chromatography on silica gel ( $n$-pentane/dichloromethane $9: 1 \rightarrow 7: 3, R_{f}(7: 3)=0.17$ ). A purple solid was obtained (619 mg, $613 \mu \mathrm{mol}, 24 \%$, Lit. ${ }^{2}:$ 24\%).

${ }^{1}$ H NMR (500 MHz, acetone-d $\mathbf{d}_{6}, 300$ K): $\delta$ = 9.31 (s, br, 4H, $H$-pyrrol,), 9.18 (s, br, 2H, $H$-pyrrol), 8.90 (d, ${ }^{3} \mathrm{~J}=3.56 \mathrm{~Hz}, 2 \mathrm{H}, H$-pyrrol), 8.34-8.29 (m, 1H, H-6'), 8.23-8.18 (m, 1H, H-3'), 7.94-7.87 (m, 2H, H-4', H-5'), 0.14 (s, 12H, H-8'a, H-8'b), -2.75 (br. s, 2H, H-N-pyrrol) ppm.

${ }^{19}$ F NMR (470 MHz, acetone-d ${ }_{6}, 300$ K): $\delta=-139.80$ to -139.92 (m, 2F, Por-Ar-o-F), -138.96 (dd, ${ }^{3} J=23.6 \mathrm{~Hz},{ }^{4} J=7.83 \mathrm{~Hz}, 2 \mathrm{~F}$, Por-Ar-o-F), -139.17 (dd, ${ }^{3} J=23.7 \mathrm{~Hz},{ }^{4} J=7.70 \mathrm{~Hz}, 2 \mathrm{~F}$, Por-Ar-oF), -154.75 (t, ${ }^{3} J=20.5$ Hz, 3F, Por-Ar-p-F), -163.56 to -163.78 (m, 6F, Por-Ar-m-F) ppm.

${ }^{11}$ B NMR (160 MHz, acetone-d 6 , 300 K): $\delta=31.80$ (s, 1B, -BPin) ppm. 
Synthesis of 5-(Phenyl-2'-(boronic acid pinacol ester))-10,15,20-tris(pentafluorophenyl)Ni(II)porphyrin (4-Ni)

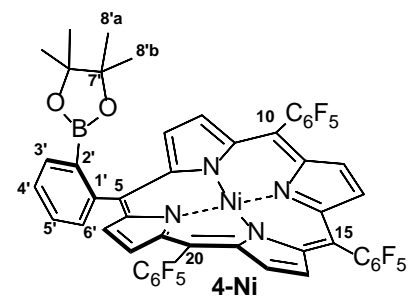

The metal free porphyrin precursor $\mathbf{4}-\mathbf{H}_{2}$ (619 $\left.\mathrm{mg}, 613 \mu \mathrm{mol}\right)$ was dissolved in toluene $(200 \mathrm{~mL})$. Nickel(II)acetylacetonate (1.60 g, $6.15 \mathrm{mmol})$ was added. The reaction mixture was stirred under reflux for $3 \mathrm{~d}$ in an oil bath. The solvent was removed under reduced pressure. The crude product was purified by column chromatography on silica gel ( $n$-pentane/dichloromethane $7: 3, R_{f}(7: 3)=0.31$ ). A purple solid was obtained (586 mg, $549 \mu \mathrm{mol}, 90 \%$, Lit. ${ }^{2}$ : 93\%).

${ }^{1} \mathbf{H}$ NMR (500 MHz, acetone-d 6 , 300 K): $\delta=$ 9.19-9.16 (m, br, 4H, H-pyrrol), 9.05 (d, ${ }^{3} J=4.98 \mathrm{~Hz}$, 2H, $H$-pyrrol), 8.80 (d, ${ }^{3} J=4.96 \mathrm{~Hz}, 2 \mathrm{H}, H$-pyrrol), 8.25 (dd, ${ }^{3} J=7.43 \mathrm{~Hz},{ }^{4} J=1.21 \mathrm{~Hz}, 1 \mathrm{H}, H-6$ '), 8.07 (dd, ${ }^{3} J=7.44 \mathrm{~Hz},{ }^{4} J=1.38 \mathrm{~Hz}, 1 \mathrm{H}, H-3$ '), 7.87 (td, ${ }^{3} J=7.55 \mathrm{~Hz},{ }^{4} J=1.58 \mathrm{~Hz}, 1 \mathrm{H}, H-5$ '), 7.82 (td, ${ }^{3} J=7.55 \mathrm{~Hz},{ }^{4} J=1.22 \mathrm{~Hz}, 1 \mathrm{H}, H-4$ '), 0.14 (s, 12H, H-8'a, $H-8$ 'b) ppm.

${ }^{19}$ F NMR (470 MHz, acetone-d 6 , 300 K): $\delta=-138.89$ (dd, ${ }^{3} J=23.7 \mathrm{~Hz},{ }^{4} J=7.61 \mathrm{~Hz}, 1 \mathrm{~F}$, Por-Ar-OF), -139.06 to -139.24 (m, 5F, Por-Ar-o-F), -154.80 (t, ${ }^{3} \mathrm{~J}=20.4 \mathrm{~Hz}, 3 \mathrm{~F}$, Por-Ar-p-F), -163.44 to -163.68 (m, 6F, Por-Ar-m-F) ppm.

${ }^{11}$ B NMR (160 MHz, acetone-d 6 , 300 K): $\delta=31.42$ (s, 1B, -BPin) ppm. 


\section{I.2.3 Synthesis Route to Isobenzofuran 5}

\section{Synthesis of 1,3-Dihydro-1-methoxyisobenzofuran ${ }^{5,6}$}

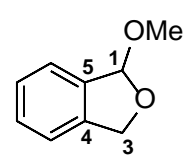

2,3-Dichloro-5,6-dicyano-1,4-benzoquinone (DDQ) (19.4 g, 85.5 mmol) were suspended under nitrogen atmosphere in dry dichloromethane. First phthalan $(7.20 \mathrm{~mL}, 7.91 \mathrm{~g}, 65.8 \mathrm{mmol})$ and then dry methanol (3.60 mL, $88.8 \mathrm{mmol}$ ) was added. The suspension was stirred for $17 \mathrm{~h}$ at room temperature. The reaction was quenched with a saturated aq. sodium hydrogen carbonate solution $(400 \mathrm{~mL})$ and filtered over celite. The filter cake was washed with a saturated aq. sodium hydrogen carbonate solution (200 mL) and with dichloromethane $(200 \mathrm{~mL})$. The aqueous phase was extracted two times with dichloromethane. The combined organic layers were dried over magnesium sulfate and the solvent was removed under reduced pressure. The crude product was purified by column chromatography on silica gel (cyclohexane/ethyl acetate 9:1, $\left.R_{f}=0.32\right)$. A colorless oil was obtained (8.67 g, 57.7 mmol, 88\%, Lit. ${ }^{5}:$ 85\%).

${ }^{1} \mathbf{H}$ NMR (200 MHz, $\mathbf{C D C l}_{3}, 300$ K): $\delta=7.75-7.28$ (m, 4H, $H$-phenyl), 6.19 (d, ${ }^{3} J=2.15 \mathrm{~Hz}, 1 \mathrm{H}, H-1$ ), 5.23 (dd, ${ }^{3} J=12.7 \mathrm{~Hz},{ }^{4} J=2.15 \mathrm{~Hz}, 1 \mathrm{H}, H-3$ ), 5.05 (d, ${ }^{3} J=12.7 \mathrm{~Hz}, 1 \mathrm{H}, H-3$ '), 3.44 (s, 3H, OMe) ppm.

\section{In situ Synthesis of Isobenzofuran $5^{4,6}$}

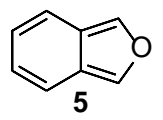

Diisopropylamine (2.50 mL, $1.80 \mathrm{~g}, 17.8 \mathrm{mmol}$ ) was dissolved in dry benzene (17.5 mL) and cooled down to $0^{\circ} \mathrm{C}$ in an ice bath. $2.5 \mathrm{M} \mathrm{N}$-butyl lithium in $n$-hexane $(7.10 \mathrm{~mL}, 17.7 \mathrm{mmol})$ was added dropwise over 10 minutes. The reaction was stirred for additional 5 minutes at $0{ }^{\circ} \mathrm{C}$. After warming up to room temperature 1,3-Dihydro-1-methoxyisobenzofuran $(1.04 \mathrm{~g}, 6.93 \mathrm{mmol}$, dissolved in dry benzene $(7.5 \mathrm{~mL})$ ) was added dropwise over 15 minutes. The reaction was stirred for additional 5 minutes at room temperature. The reaction was quenched with a saturated aq. ammonium chloride solution $(20 \mathrm{~mL})$. The organic layer was washed twice with water $(20 \mathrm{~mL})$ and dried over magnesium sulfate. The filtrate ( $85 \mathrm{~mL}$ benzene in total) was used in situ for Diels Alder reactions. 


\section{I.2.4 Synthesis of Ni(II) Chlorin Precursors 6a-Ni and 6b-Ni}

Synthesis of 5-(Phenyl-2'-(boronic acid pinacol ester))-10,15,20-tris(pentafluorophenyl)-Ni(II)chlorin (6a-Ni and 6b-Ni)
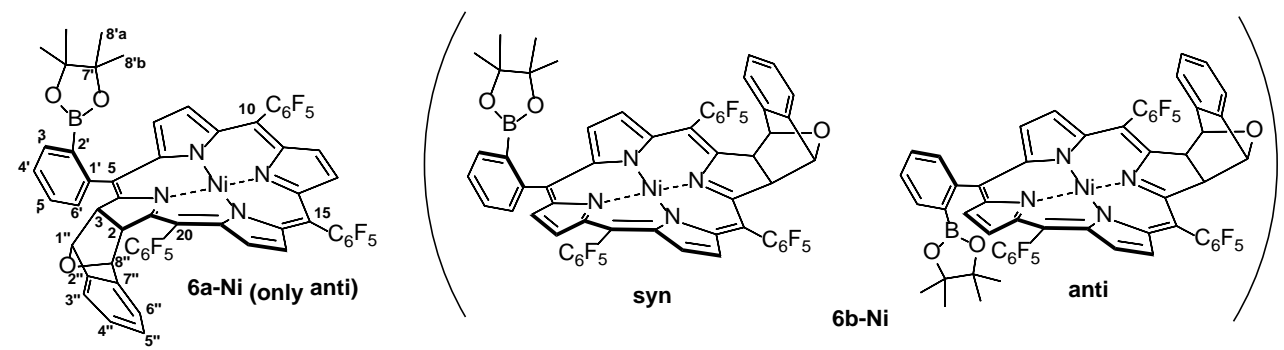

The Ni(II) porphyrin precursor 4-Ni $(414 \mathrm{mg}, 388 \mu \mathrm{mol})$ was dissolved in an in situ prepared isobenzofuran 5 solution in benzene $(85 \mathrm{~mL}$ ) (see I.2.2, 18 equivalents of 1,3-Dihydro-1methoxyisobenzofuran were used relative to compound 4-Ni). The reaction mixture was stirred for $16 \mathrm{~h}$ at $70{ }^{\circ} \mathrm{C}$ in an oil bath. The solvent was removed under reduced pressure. The crude product was purified by column chromatography on silica gel (n-pentane/dichloromethane $7: 3 \rightarrow 6: 4 \rightarrow 1: 1 \rightarrow 4: 6, R_{f}(6: 4)=$ 0.11 (6a-Ni) and 0.21 (6b-Ni)). A green solid was obtained (6a-Ni: $60.2 \mathrm{mg}, 50.8 \mu \mathrm{mol}, 13 \%$, 6b-Ni: $60.0 \mathrm{mg}, 50.6 \mu \mathrm{mol}, 13 \%)$.

The following NMR data analysis only refers to $\mathbf{6 a - N i , ~ b e c a u s e ~} \mathbf{6 b}-\mathbf{N i}$ is a mixture of two isomers (syn and anti, ratio 4:6) with a doubled data set in the NMR spectrum (cf. chapter VI).

FT IR (layer): $\tilde{v}=2923$ (w), 1651 (w), 1593 (w), 1526 (w), 1518 (s), 1487 (s), 1438 (m), 1350 (s), 1316 (m), 1274 (w), 1143 (m), 1062 (s), 1009 (m), 986 (vs), 946 (s), 839 (s), 754 (s), 701 (m), 661 (m), $593(\mathrm{~m}), 545(\mathrm{w}), 402(\mathrm{~m}) \mathrm{cm}^{-1}$.

${ }^{1} \mathrm{H}$ NMR (500 MHz, CDCl 3 , 300 K): $\delta=8.26\left(\mathrm{~d},{ }^{3} J=4.90 \mathrm{~Hz}, 1 \mathrm{H}\right.$, Pyrrol-H), $8.16\left(\mathrm{~d},{ }^{3} J=4.72 \mathrm{~Hz}\right.$, 2H, Pyrrol- $H$ ), 8.14 (d, ${ }^{3} J=4.81 \mathrm{~Hz}, 1 \mathrm{H}$, Pyrrol- $H$ ), 8.07 (d, ${ }^{3} J=4.96 \mathrm{~Hz}, 1 \mathrm{H}$, Pyrrol- $H$ ), 8.05 (dd, $\left.{ }^{3} J=7.57 \mathrm{~Hz},{ }^{4} J=1.02 \mathrm{~Hz}, 1 \mathrm{H}, H-6{ }^{\prime}\right), 8.01$ (dd, $\left.{ }^{3} J=4.78 \mathrm{~Hz},{ }^{4} J=1.95 \mathrm{~Hz}, 1 \mathrm{H}, H-3{ }^{\prime}\right), 7.99$ (d, ${ }^{3} J=7.46 \mathrm{~Hz}, 1 \mathrm{H}$, Pyrrol- $H$ ), 7.84 (td, ${ }^{3} J=7.50 \mathrm{~Hz},{ }^{4} J=1.32 \mathrm{~Hz}, 1 \mathrm{H}, H-4$ ), 7.70 (td, ${ }^{3} J=7.53 \mathrm{~Hz}$, $\left.{ }^{4} J=0.77 \mathrm{~Hz}, 1 \mathrm{H}, H-5^{\prime}\right), 6.45$ (d, ${ }^{3} J=7.30 \mathrm{~Hz}, 1 \mathrm{H}, H-3$ "), 6.33 (d, ${ }^{3} J=7.37 \mathrm{~Hz}, 1 \mathrm{H}, H-6$ "), 5.99 (t, $\left.{ }^{3} J=7.40 \mathrm{~Hz}, 1 \mathrm{H}, H-4 "\right), 5.91$ (t, ${ }^{3} J=7.43 \mathrm{~Hz}, 1 \mathrm{H}, H-5$ "), 5.47 (d, $\left.{ }^{3} J=5.64 \mathrm{~Hz}, 1 \mathrm{H}, \mathrm{H}-8^{\prime \prime}\right), 5.45$ (dd, ${ }^{4} J=5.68 \mathrm{~Hz}, 1 \mathrm{H}, \mathrm{H}-3$ ), 5.39 (d, ${ }^{3} J=5.70 \mathrm{~Hz}, 1 \mathrm{H}, \mathrm{H}-1$ "), 5.13 (dd, ${ }^{3} J=9.48 \mathrm{~Hz},{ }^{4} J=5.64 \mathrm{~Hz}, 1 \mathrm{H}, \mathrm{H}-2$ ), 0.56 (s, 6H, $H-8$ 'a), 0.40 (s, 6H, $H-8 ' b)$ ppm.

${ }^{13} \mathbf{C}\left\{{ }^{1} \mathbf{H}\right\}$ NMR (125 MHz, $\mathbf{C D C l}_{3}, 300$ K): $\delta=144.5,141.8,140.5,135.2,132.6,132.6,131.6,131.5$, 130.0, 130.0, 128.0, 128.0, 127.6, 126.8, 126.0, 126.0, 119.8, 118.8, 83.2, 82.9, 54.0, 52.8, 23.9, 23.9 ppm, C atoms of the porphyrin and perfluorinated meso aryl substituents are not detectable because of the low concentration. 
${ }^{19}$ F NMR (470 MHz, $\left.\mathbf{C D C l}_{3}, \mathbf{3 0 0} \mathbf{K}\right): \delta=-135.75$ (dd, ${ }^{3} \mathrm{~J}=24.2 \mathrm{~Hz},{ }^{4} \mathrm{~J}=7.05 \mathrm{~Hz}, 1 \mathrm{~F}$, Por-Ar-oF), -137.84 (dd, ${ }^{3} J=24.0 \mathrm{~Hz},{ }^{4} J=7.40 \mathrm{~Hz}, 1 \mathrm{~F}$, Por-Ar-o-F), -137.90 to -138.29 (m, 4F, Por-Ar-oF), $-152.10\left(\mathrm{t},{ }^{3} J=20.7 \mathrm{~Hz}, 1 \mathrm{~F}\right.$, Por-Ar-p-F), $-152.90\left(\mathrm{t},{ }^{3} \mathrm{~J}=20.8 \mathrm{~Hz}, 1 \mathrm{~F}\right.$, Por-Ar-p-F), -153.01 (t, ${ }^{3} J=$ $21.0 \mathrm{~Hz}, 1 \mathrm{~F}$, Por-Ar-p-F), -160.54 to -160.81 (m, 2F, Por-Ar-m-F), -162.02 to -162.28 (m, 4F, Por-Ar$m-F)$ ppm.

${ }^{11}$ B NMR (160 MHz, $\mathbf{C D C l}_{3}, 300$ K): $\delta=31.05$ (s, 1B, -BPin) ppm.

MS (6a-Ni and 6b-Ni, ESI-TOF, acetone): m/z (\%) = 1184.15 (99) [M] $]^{+}, 1167.15$ (2) [Misobenzofurane $]^{+}$.

HR MS (6a-Ni and 6b-Ni, ESI-TOF, acetone): $\mathrm{m} / \mathrm{z}[\mathrm{M}]^{\cdot+}$ calcd for $\mathrm{C}_{58} \mathrm{H}_{30} \mathrm{O}_{3} \mathrm{~N}_{4}{ }^{10} \mathrm{BF}_{15}{ }^{58} \mathrm{Ni}, 1183.1556$; found 1183.1541 (-1.23 ppm).

UV vis (6a-Ni, $\left.\mathrm{CH}_{3} \mathrm{CN}\right): \lambda_{\max }(\lg \varepsilon)=409$ (5.07), 503 (3.68), 578 (3.80), 617 (4.44) nm. UV-vis (6b-Ni, $\left.\mathrm{CH}_{3} \mathrm{CN}\right): \lambda_{\max }(\lg \varepsilon)=405$ (5.08), 494 (3.63), 570 (3.80), 612 (4.54) nm.

As side product (blue solid) in this reaction a mixture of isomers of the isobacteriochlorin precursor 6c-Ni was obtained $\left(\mathrm{R}=\mathrm{C}_{6} \mathrm{~F}_{5}\right)$ :

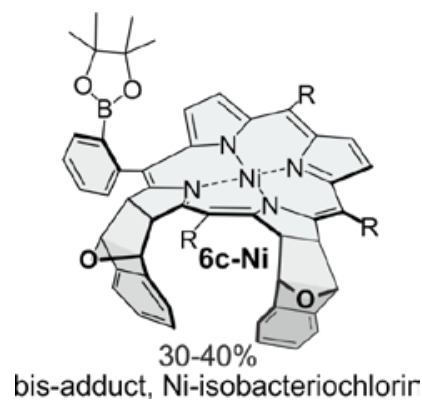

Yield: 6c-Ni: 152.8-203.8 mg, 117-156 $\mu \mathrm{mol}, 30-40 \%$.

MS (ESI-TOF, acetone): $\mathrm{m} / \mathrm{z}(\%)=1302.19(43)[\mathrm{M}]^{+}$.

HR MS (ESI-TOF, acetone): $\mathrm{m} / \mathrm{z}[\mathrm{M}]^{\cdot+}$ calcd for $\mathrm{C}_{66} \mathrm{H}_{36} \mathrm{O}_{4} \mathrm{~N}_{4}{ }^{10} \mathrm{BF}_{15}{ }^{58} \mathrm{Ni}, 1301.1974$; found 1301.1983 (+0.65 ppm).

\section{I.2.5 Synthesis Route to Ni(II) Bacteriochlorin Precursor 7-Ni}

Synthesis of 5-(Phenyl-2'-(boronic acid pinacol ester))-10,15,20-tris(pentafluorophenyl)bacteriochlorin $\left(7-\mathrm{H}_{2}\right)$

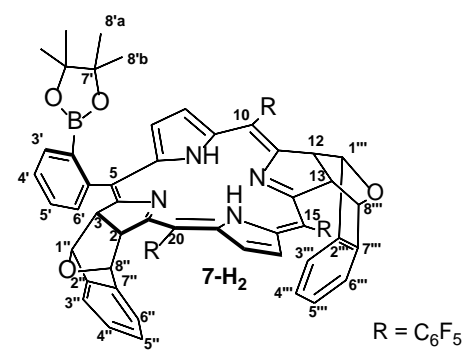


The metal free porphyrin precursor 4-H $\mathbf{4}(1.97 \mathrm{~g}, 1.95 \mathrm{mmol})$ was dissolved in an in situ prepared isobenzofuran 5 solution in benzene $(140 \mathrm{~mL}$ ) (see I.2.2, 18 equivalents of 1,3-Dihydro-1methoxyisobenzofuran were used relative to compound $\mathbf{4}-\mathbf{H}_{2}$ ). The reaction mixture was stirred for $41 \mathrm{~h}$ at $70{ }^{\circ} \mathrm{C}$ in an oil bath. The solvent was removed under reduced pressure. The crude product was purified by column chromatography on silica gel (n-pentane/dichloromethane $1: 1 \rightarrow 8: 2 \rightarrow \mathrm{DCM}, R_{f}(D C M)=$ 0.64. An olive-green solid was obtained (515 mg, $413 \mathrm{mmol}$, 21\%).

FT IR (layer): $\tilde{v}=3391$ (w), 2974 (w),1775 (w), 1651 (w), 1587 (m), 1520 (s), 1493 (s), 1434 (m), 1349 (s), 1315 (m), 1273 (m), 1213 (w), 1186 (w), 1144 (m), 1039 (s), 985 (s), 912 (s), 824 (vs), 746 (s), 724 (s), 685 (s), 621 (s), 575 (s), 535 (m), 435 (m) cm-1.

${ }^{1} \mathbf{H}$ NMR (500 MHz, $\left.\mathbf{C D C l}_{3}, \mathbf{3 0 0} \mathbf{~ K}\right): \delta=8.16\left(\mathrm{dd},{ }^{3} J=7.55 \mathrm{~Hz},{ }^{4} J=1.30 \mathrm{~Hz}, 1 \mathrm{H}, H-3\right.$ ), 8.10 (d, $\left.{ }^{3} J=7.55 \mathrm{~Hz}, 1 \mathrm{H}, H-6^{\prime}\right), 8.01$ (dd, ${ }^{3} J=4.62 \mathrm{~Hz},{ }^{4} J=1.65 \mathrm{~Hz}, 1 \mathrm{H}, H$-pyrrole), 7.95-7.87 (m, 4H, $H$-pyrrole, $H$-5'), 7.77 (td, ${ }^{3} J=7.55 \mathrm{~Hz},{ }^{4} J=1.03 \mathrm{~Hz}, 1 \mathrm{H}, H-4$ '), 6.36 (d, $\left.{ }^{3} J=7.26 \mathrm{~Hz}, 1 \mathrm{H}, H-3 "\right), 6.26$ 6.19 (m, 3H, H-6", H-3"', H-6"'), 5.75 (t, $\left.{ }^{3} J=7.30 \mathrm{~Hz}, 1 \mathrm{H}, H-4 "\right), 5.67$ (t, $\left.{ }^{3} J=7.31 \mathrm{~Hz}, 1 \mathrm{H}, H-5 "\right), 5.65-$ 5.58 (m, 3H, $H-4$ "', $H-5$ "', $H-1$ "), 5.45 (br.s, 2H, $H-1 " ', H-8 " '), 5.42-5.36$ (m, 3H, $H-3, H-8 ", H-13$ ), 5.21 (dd, ${ }^{3} J=10.8 \mathrm{~Hz},{ }^{4} J=0.99 \mathrm{~Hz}, 1 \mathrm{H}, H-12$ ), 5.16 (d, ${ }^{3} J=5.73 \mathrm{~Hz}, 1 \mathrm{H}, H-2$ ), 0.51 (s, 6H, H-8'a), 0.37 (s, 6H, $H-8$ 'b), -2.71 (s, 1H, H-N-pyrrole), -2.85 (s, 1H, H-N-pyrrole) ppm.

${ }^{13} \mathbf{C}\left\{{ }^{1} \mathbf{H}\right\}$ NMR (125 MHz, $\left.\mathbf{C D C l}_{3}, \mathbf{3 0 0} \mathbf{K}\right): \delta=146.2,142.3,141.3,135.3,134.4,131.4,129.8,128.0$, 126.3, 125.2, 125.1, 125.0, 124.9, 122.1, 120.3, 119.9, 119.8, 119.4, 119.3, 118.8, 83.4, 82.5, 82.5), 82.5, 57.5, 56.7, 55.5, 55.3, 24.1, $23.6 \mathrm{ppm}, \mathrm{C}$ atoms of the porphyrin and perfluorinated meso aryl substituents are not detectable because of the low concentration.

${ }^{19}$ F NMR (470 MHz, $\left.\mathbf{C D C l}_{3}, \mathbf{3 0 0} \mathbf{K}\right): \delta=-135.89\left(\mathrm{dd},{ }^{3} \mathrm{~J}=23.6 \mathrm{~Hz},{ }^{4} \mathrm{~J}=6.59 \mathrm{~Hz}, 1 \mathrm{~F}\right.$, Por-Ar-oF), -136.08 (td, ${ }^{3} J=26.4 \mathrm{~Hz},{ }^{4} J=6.32 \mathrm{~Hz}, 2 \mathrm{~F}$, Por-Ar-o-F), -137.35 (dd, ${ }^{3} J=24.2 \mathrm{~Hz},{ }^{4} J=7.25 \mathrm{~Hz}$, 1F, Por-Ar-o-F), -137.76 (dd, ${ }^{3} J=24.4 \mathrm{~Hz},{ }^{4} J=7.60 \mathrm{~Hz}, 1 \mathrm{~F}$, Por-Ar-o-F), -138.89 (dd, ${ }^{3} J=23.9 \mathrm{~Hz}$, ${ }^{4} J=7.40 \mathrm{~Hz}, 1 \mathrm{~F}$, Por-Ar-o-F), -153.32 (t, ${ }^{3} J=21.0 \mathrm{~Hz}, 1 \mathrm{~F}$, Por-Ar-p-F), -152.47 (t, ${ }^{3} \mathrm{~J}=21.0 \mathrm{~Hz}, 1 \mathrm{~F}$, Por-Ar-p-F), -152.64 (t, ${ }^{3} J=21.0 \mathrm{~Hz}, 1 \mathrm{~F}$, Por-Ar-p-F), -160.57 to -160.82 (m, 2F, Por-Ar-m-F), -160.95 to -161.25 (m, 4F, Por-Ar-m-F) ppm.

${ }^{11}$ B NMR (160 MHz, $\mathbf{C D C l}_{3}, 300$ K): $\delta=30.23$ (s, 1B, -BPin) ppm.

MS (ESI-TOF, acetone): $\mathrm{m} / \mathrm{z} \quad(\%)=1010.2 \quad(13) \quad[\mathrm{M}-2 \cdot \text { Isobenzofuran }]^{+}, \quad 1128.2$ (13) [M-1·Isobenzofuran] $]^{+}, 1246.3(99)[\mathrm{M}]^{+}$.

HR MS (ESI-TOF, acetone): $\mathrm{m} / \mathrm{z}[\mathrm{M}]^{\cdot+}$ calcd for $\mathrm{C}_{66} \mathrm{H}_{38} \mathrm{O}_{4} \mathrm{~N}_{4}{ }^{11} \mathrm{BF}_{15}, 1245.2777$; found 1245.2782 (+0.3 ppm).

As side products in this reaction the chlorin precursors $6 \mathbf{a}-\mathbf{H}_{\mathbf{2}}$ and $\mathbf{6 b}-\mathbf{H}_{\mathbf{2}}$ were obtained: 

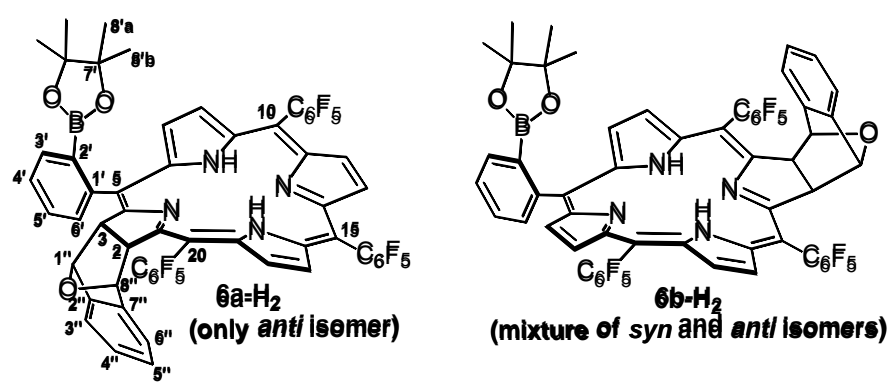

Yield: $\mathbf{6 a}-\mathbf{H}_{2}: 264.0 \mathrm{mg}, 234 \mu \mathrm{mol}, 12 \%$.

6b-H2: 373.7 mg, $331 \mu \mathrm{mol}, 17 \%$;

$\mathbf{R}_{f}$ (n-pentane/dichlomethane, 6:4): $0.09\left(\mathbf{6 a}-\mathbf{H}_{2}\right)$ and $0.23\left(\mathbf{6 b}-\mathbf{H}_{2}\right)$.

FT IR (layer): $\tilde{v}=2924$ (w), 1650 (w), 1579 (m), 1518 (s), 1494 (s), 1351 (s), 1318 (m), 1143 (m), 1041 (s), 987 (vs), 949 (s), 925 (s), 839 (s), 819 (s), 751 (s), 692 (s), 662 (m), 635 (m), 577 (m), 524 (m), $458(\mathrm{~m}), 410(\mathrm{~m}) \mathrm{cm}^{-1}$.

The following NMR data analysis only refers to $\mathbf{6 a}-\mathbf{H}_{2}$, because $\mathbf{6 b}-\mathbf{H}_{2}$ is a mixture of two isomers (syn and anti) with a doubled data set in the NMR spectrum (cf. chapter VI).

${ }^{1}$ H NMR (500 MHz, CDCl 3 , 300 K): $\delta=8.65\left(\mathrm{~d},{ }^{3} J=4.80 \mathrm{~Hz}, 1 \mathrm{H}\right.$, Pyrrol- $H$ ), $8.54\left(\mathrm{~d},{ }^{3} \mathrm{~J}=4.90 \mathrm{~Hz}\right.$, 1H, Pyrrol- $H$ ), 8.47 (d, ${ }^{3} J=4.50 \mathrm{~Hz}, 1 \mathrm{H}$, Pyrrol- $H$ ), 8.44 (d, ${ }^{3} J=4.50 \mathrm{~Hz}, 1 \mathrm{H}$, Pyrrol-H), 8.39-8.34 (m, 2H, Pyrrol-H), 8.24 (dd, ${ }^{3} J=7.59 \mathrm{~Hz},{ }^{4} J=1.34 \mathrm{~Hz}, 1 \mathrm{H}, H-3^{\prime}$ ), 8.21 (d, ${ }^{3} J=7.50 \mathrm{~Hz}, 1 \mathrm{H}, H-6$ '), 7.98 (td, $\left.{ }^{3} J=7.50 \mathrm{~Hz},{ }^{4} J=1.48 \mathrm{~Hz}, 1 \mathrm{H}, H-5^{\prime}\right), 7.84\left(\mathrm{td},{ }^{3} J=7.59 \mathrm{~Hz},{ }^{4} J=1.05 \mathrm{~Hz}, 1 \mathrm{H}, H-4^{\prime}\right), 6.61$ (d, $\left.{ }^{3} J=7.35 \mathrm{~Hz}, 1 \mathrm{H}, H-3 "\right), 6.48$ (d, $\left.{ }^{3} J=7.24 \mathrm{~Hz}, 1 \mathrm{H}, H-6 "\right), 5.94$ (dd, ${ }^{3} J=8.71 \mathrm{~Hz},{ }^{4} J=5.74 \mathrm{~Hz}, 1 \mathrm{H}, H-8$ ), $5.91\left(\mathrm{td},{ }^{3} J=7.34 \mathrm{~Hz},{ }^{4} J=0.86 \mathrm{~Hz}, 1 \mathrm{H}, H-4 "\right), 5.84\left(\mathrm{td},{ }^{3} J=7.41 \mathrm{~Hz},{ }^{4} J=0.82 \mathrm{~Hz}, 1 \mathrm{H}, H-5 "\right), 5.56$ (dd, ${ }^{3} J=8.71 \mathrm{~Hz},{ }^{4} J=5.81 \mathrm{~Hz}, 1 \mathrm{H}, H-7$ ), 5.48 (d, $\left.{ }^{3} J=5.62 \mathrm{~Hz}, 1 \mathrm{H}, H-1 "\right), 5.25$ (d, $\left.{ }^{3} J=5.74 \mathrm{~Hz}, 1 \mathrm{H}, H-8 "\right)$, 0.44 (s, 6H, H-8'a), 0.29 (s, 6H, H-8'b), -2.40 (s, 1H, $H$-N-pyrrole), -2.56 (s, $1 \mathrm{H}, H$-N-pyrrole) ppm.

${ }^{13} \mathbf{C}\left\{{ }^{1} \mathbf{H}\right\}$ NMR (125 MHz, $\left.\mathbf{C D C l}_{3}, \mathbf{3 0 0} \mathbf{K}\right): \delta=146.5,142.6,141.5,135.7,134.3,132.0,132.0,131.7$, 129.9, 128.1, 126.9, 126.8, 126.8, 125.9, 125.8, 123.0, 119.9, 119.2, 83.3, 82.8, 82.8, 58.1, 56.7, 24.1, $23.6 \mathrm{ppm}, \mathrm{C}$ atoms of the porphyrin and perfluorinated meso aryl substituents are not detectable because of the low concentration.

${ }^{19}$ F NMR (470 MHz, $\left.\mathbf{C D C l}_{3}, 300 \mathrm{~K}\right): \delta=-135.38\left(\mathrm{dd},{ }^{3} \mathrm{~J}=24.0 \mathrm{~Hz},{ }^{4} \mathrm{~J}=7.29 \mathrm{~Hz}, 1 \mathrm{~F}\right.$, Por-Ar-OF), -137.26 (dd, ${ }^{3} J=24.0 \mathrm{~Hz},{ }^{4} J=7.40 \mathrm{~Hz}, 1 \mathrm{~F}$, Por-Ar-o-F), -137.41 to -137.54 (m, 2F, Por-Ar-oF), -137.60 (dd, ${ }^{3} J=24.0 \mathrm{~Hz},{ }^{4} J=7.66 \mathrm{~Hz}, 1 \mathrm{~F}$, Por-Ar-o-F), -138.65 (dd, ${ }^{3} J=24.0 \mathrm{~Hz},{ }^{4} J=6.60 \mathrm{~Hz}$, 1F, Por-Ar-o-F), -152.02 (t, ${ }^{3} J=20.8 \mathrm{~Hz}, 1 \mathrm{~F}$, Por-Ar-p-F), -152.70 (t, ${ }^{3} J=20.9 \mathrm{~Hz}, 1 \mathrm{~F}$, Por-Ar-pF), -152.86 (t, ${ }^{3} J=20.8 \mathrm{~Hz}, 1 \mathrm{~F}$, Por-Ar-p-F), -160.36 (td, ${ }^{3} J=22.3 \mathrm{~Hz},{ }^{4} J=7.65 \mathrm{~Hz}, 1 \mathrm{~F}$, Por-Ar-mF), -160.66 (td, ${ }^{3} J=22.4 \mathrm{~Hz},{ }^{4} J=7.76 \mathrm{~Hz}, 1 \mathrm{~F}$, Por-Ar-m-F), -162.24 (td, ${ }^{3} J=21.6 \mathrm{~Hz}, 2 \mathrm{~F}$, Por-Ar- $m-$ F), -162.39 (td, ${ }^{3} J=22.4 \mathrm{~Hz},{ }^{4} J=7.04 \mathrm{~Hz}, 2 \mathrm{~F}$, Por-Ar-m-F) ppm.

${ }^{11}$ B NMR (160 MHz, $\mathbf{C D C l}_{3}, 300$ K): $\delta=32.00$ (s, 1B, -BPin) ppm. 
MS (6a-H $\mathbf{H}_{2}$ and 6b-H2, ESI-TOF, acetone): $\mathrm{m} / \mathrm{z}(\%)=1129.2(40)[\mathrm{M}+\mathrm{H}]^{+}$.

HR MS (6a- $\mathbf{H}_{2}$ and $\left.\mathbf{6 b}-\mathbf{H}_{2}, \mathbf{E S I}\right): \mathrm{m} / \mathrm{z}[\mathrm{M}+\mathrm{H}]^{+}$calcd for $\mathrm{C}_{58} \mathrm{H}_{33} \mathrm{~N}_{4} \mathrm{O}_{3}{ }^{10} \mathrm{BF}_{15}, 1128.2437$; found 1128.2427 (-0.92 ppm).

\section{Synthesis of 5-(Phenyl-2'-(boronic acid pinacol ester))-10,15,20-tris(pentafluorophenyl)-Ni(II)-} bacteriochlorin (7-Ni )

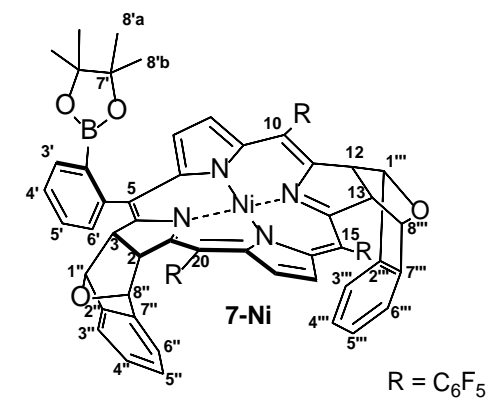

In the glove box the metal free bacteriochlorin precursor $\mathbf{7 - \mathbf { H } _ { 2 }}$ (203 $\mathrm{mg}, 162 \mu \mathrm{mol}$ ) and bis(cyclooctadiene)nickel(0) (163 mg, $593 \mu \mathrm{mol})$ were dissolved in toluene $(100 \mathrm{~mL})$. The reaction mixture was stirred for $1.5 \mathrm{~h}$ at room temperature under a nitrogen atmosphere. The solvent was removed under reduced pressure. To oxidize the pyrrocorphin 8-Ni (side product, blue colored) back to the bacteriochlorin 7-Ni (magenta colored) the mixture (pink) was dissolved in chloroform (500 mL). Trifluoroacetic acid $(0.25 \mathrm{~mL})$ was added. The reaction mixture was stirred in a buffled flask under an oxygen atmosphere for $16 \mathrm{~h}$ at room temperature. The solvent was removed under reduced pressure. The crude product was purified by column chromatography on silica gel (dichloromethane, $R_{f}=0.65$ ). A magenta solid was obtained (125 mg, $96.2 \mu \mathrm{mol}, 59 \%$ ).

FT IR (layer): $\tilde{v}$ = 2932 (w), 2251 (w), 1651 (w), 1594 (w), 1520 (s), 1486 (s), 1435 (m), 1347 (s), 1317 (m), 1175 (s), 1061 (s), 977 (vs), 930 (s), 887 (m), 840 (s), 790 (m), 752 (s), 692 (s), 662 (s), 634 (m), 592 (s), 559 (m), $492(\mathrm{~m}), 4208 \mathrm{~m}) \mathrm{cm}^{-1}$.

${ }^{1} \mathbf{H}$ NMR (500 MHz, CDCl 3,300 K): $\delta=8.06\left(\mathrm{~d},{ }^{3} J=7.60 \mathrm{~Hz}, 1 \mathrm{H}, H-3^{\prime}\right), 7.94\left(\mathrm{~d},{ }^{3} \mathrm{~J}=4.77 \mathrm{~Hz}, 1 \mathrm{H}, \mathrm{H}-\right.$ Pyrrol), 7.93 (dd, ${ }^{3} J=7.54 \mathrm{~Hz},{ }^{4} J=1.15 \mathrm{~Hz}, 1 \mathrm{H}, H-6$ '), 7.83 (td, ${ }^{3} J=7.59 \mathrm{~Hz},{ }^{4} J=1.41 \mathrm{~Hz}, 1 \mathrm{H}, H-4^{\prime}$ ), 7.69-7.66 (m, 3H, H-Pyrrol), 7.64 (td, ${ }^{3} J=7.57 \mathrm{~Hz},{ }^{4} J=1.03 \mathrm{~Hz}, 1 \mathrm{H}, H-5$ ), 6.42 (d, ${ }^{3} J=7.04 \mathrm{~Hz}, 1 \mathrm{H}$, $H-3 "), 6.32$ (d, $\left.{ }^{3} J=7.40 \mathrm{~Hz}, 1 \mathrm{H}, H-6 "\right), 6.28$ (d, $\left.{ }^{3} J=7.18 \mathrm{~Hz}, 2 \mathrm{H}, H-3^{\prime \prime \prime} / 6{ }^{\prime \prime}\right), 6.13$ (t, ${ }^{3} J=7.40 \mathrm{~Hz}, 1 \mathrm{H}$, $H-4$ "' or 5"'), 6.10 (t, ${ }^{3} J=7.24 \mathrm{~Hz}, 1 \mathrm{H}, H-4 " '$ or $\left.5 " '\right), 6.06$ (t, $\left.{ }^{3} \mathrm{~J}=7.07 \mathrm{~Hz}, 1 \mathrm{H}, H-4 "\right), 6.03$ (t, ${ }^{3} \mathrm{~J}=7$. $40 \mathrm{~Hz}, 1 \mathrm{H}, H-5 "), 5.45$ (d, $\left.{ }^{3} J=5.28 \mathrm{~Hz}, 1 \mathrm{H}, H-1{ }^{\prime \prime}\right), 5.33$ (d, $\left.{ }^{3} \mathrm{~J}=5.44 \mathrm{~Hz}, 1 \mathrm{H}, H-1 "\right), 5.31$ (d, $\left.{ }^{3} J=5.73 \mathrm{~Hz}, 1 \mathrm{H}, H-8 " '\right), 5.27$ (d, $\left.{ }^{3} J=5.14 \mathrm{~Hz}, 1 \mathrm{H}, H-8 "\right), 5.15$ (dd, ${ }^{3} J=9.91 \mathrm{~Hz},{ }^{3} J=5.58 \mathrm{~Hz}, 1 \mathrm{H}, H-$ 3), 5.04 (dd, ${ }^{3} J=9.84 \mathrm{~Hz},{ }^{3} J=5.36 \mathrm{~Hz}, 1 \mathrm{H}, H-13$ ), 4.97 (dd, ${ }^{3} J=9.90 \mathrm{~Hz},{ }^{3} J=5.36 \mathrm{~Hz}, 1 \mathrm{H}, H-12$ ), 4.81 (dd, ${ }^{3} J=9.89 \mathrm{~Hz},{ }^{3} J=5.57 \mathrm{~Hz}, 1 \mathrm{H}, H-2$ ), 0.42 (s, 6H, $H-8$ 'a), 0.33 (s, 6H, $H-8$ 'b) ppm.

${ }^{13} \mathbf{C}\left\{{ }^{1} \mathbf{H}\right\}$ NMR (151 MHz, $\left.\mathbf{C D C l}_{3}, \mathbf{3 0 0} \mathbf{K}\right): \delta=143.8,140.8,140.8,140.7,135.1,132.5,131.9,129.9$, 129.3, 127.9, 125.8, 125.7, 125.5, 125.5, 125.5, 125.4, 119.9, 119.5, 119.2, 118.5, 115.4, 83.3, 82.7, 
82.5, 82.5, 82.4, 54.7, 52.5, 52.0, 51.0, $23.8 \mathrm{ppm}, \mathrm{C}$ atoms of the porphyrin and perfluorinated meso aryl substituents are not detectable.

${ }^{19}$ F NMR (470 MHz, CDCl 3 , 300 K): $\delta=-135.89\left(\mathrm{dd},{ }^{3} J=23.9 \mathrm{~Hz},{ }^{4} \mathrm{~J}=6.56 \mathrm{~Hz}, 1 \mathrm{~F}\right.$, Por-Ar-oF), -136.50 (dd, ${ }^{3} J=23.9 \mathrm{~Hz},{ }^{4} J=7.25 \mathrm{~Hz}, 1 \mathrm{~F}$, Por-Ar-o-F), -137.20 (dd, ${ }^{3} J=24.3 \mathrm{~Hz},{ }^{4} J=7.24 \mathrm{~Hz}$, 1F, Por-Ar-o-F), -137.56 (dd, ${ }^{3} J=24.2 \mathrm{~Hz},{ }^{4} J=6.69 \mathrm{~Hz}, 1 \mathrm{~F}$, Por-Ar-o-F), -137.68 (dd, ${ }^{3} J=24.2 \mathrm{~Hz}$, ${ }^{4} J=7.21 \mathrm{~Hz}, 1 \mathrm{~F}$, Por-Ar-o-F), -138.00 (dd, ${ }^{3} J=23.9 \mathrm{~Hz},{ }^{4} J=7.21 \mathrm{~Hz}, 1 \mathrm{~F}$, Por-Ar-o-F), -152.42 (t, ${ }^{3} J=20.8 \mathrm{~Hz}, 1 \mathrm{~F}$, Por-Ar-p-F), -152.66 (t, ${ }^{3} J=21.0 \mathrm{~Hz}, 1 \mathrm{~F}$, Por-Ar-p-F), -152.74 (t, ${ }^{3} J=21.0 \mathrm{~Hz}, 1 \mathrm{~F}$, Por-Ar-p-F), -160.66 (td, ${ }^{3} J=22.6 \mathrm{~Hz},{ }^{4} J=7.79 \mathrm{~Hz}, 1 \mathrm{~F}$, Por-Ar- $m-F$ ), -160.84 (td, ${ }^{3} J=22.2 \mathrm{~Hz}$, ${ }^{4} J=7.40 \mathrm{~Hz}, 1 \mathrm{~F}$, Por-Ar-m-F), -161.02 to -161.29 (m, 4F, Por-Ar-m-F) ppm.

${ }^{11}$ B NMR (160 MHz, CDCl 3 , 300 K): $\delta=30.27$ (s, 1B, -BPin) ppm.

MS (ESI-TOF, acetone): $\mathrm{m} / \mathrm{z}(\%)=1302.19(43)[\mathrm{M}]^{+}$.

HR MS (ESI-TOF, acetone): $\mathrm{m} / \mathrm{z}[\mathrm{M}]^{\cdot+}$ calcd for $\mathrm{C}_{66} \mathrm{H}_{36} \mathrm{O}_{4} \mathrm{~N}_{4}{ }^{10} \mathrm{BF}_{15}{ }^{58} \mathrm{Ni}, 1301.1974$; found 1301.1983 (+0.65 ppm).

UV vis $\left(\mathrm{CH}_{3} \mathrm{CN}\right): \lambda_{\max }(\lg \varepsilon)=341$ (4.66), 401 (4.87), 517 (4.10), 615 (3.77), 756 (4.83) nm.

\section{I.2.6 Synthesis of Record Players 10a, 10b and 11}

\section{Synthesis of 5-(Biphenylazo-4-methoxypyridine)-10,15,20-tris(pentafluorophenyl)nickel(II)- chlorin (10a and 10b)}

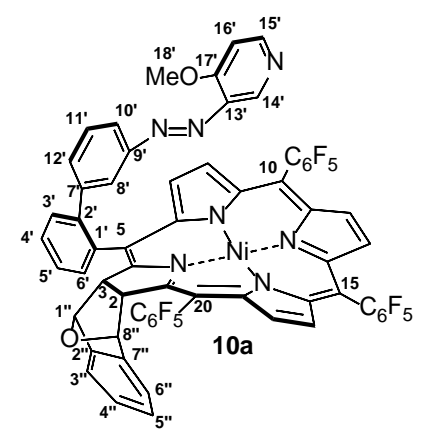

The Ni(II)chlorin precursor 6a-Ni (60.2 mg, 50.8 pmol), 3-(3-bromophenylazo)-4-methoxypyridine (9) (22.3 mg, $76.2 \mu \mathrm{mol}), \mathrm{Pd}\left(\mathrm{PPh}_{3}\right)_{4}(8.00 \mathrm{mg}, 6.92 \mu \mathrm{mol})$ and potassium bicarbonate (24.6 mg, $178 \mu \mathrm{mol}$ ) were weighted out and were set under nitrogen. Toluene $(16 \mathrm{~mL})$, ethanol $(5 \mathrm{~mL})$ and water $(3.6 \mathrm{~mL})$ were added. The reaction mixture was stirred for $90 \mathrm{~h}$ at $40^{\circ} \mathrm{C}$ in an oil bath. Ethyl acetate $(20 \mathrm{~mL})$ and water $(20 \mathrm{~mL}$ ) were added. The aqueous layer was extracted twice with ethyl acetate (each $20 \mathrm{~mL}$ ). The organic layer was dried over magnesium sulfate and evaporated to dryness. The crude product was purified via column chromatography on silica gel (cyclohexane/ethyl acetate, 3:2, $R_{\mathrm{f}}=0.26$ (trans), $R_{\mathrm{f}}$ $=0.71$ (cis)) and the desired product was obtained as green solid (19.1 mg, $15.9 \mu \mathrm{mol}, 30 \%)$. 
${ }^{1}$ H NMR (500 MHz, Aceton-d $\mathbf{d}_{6}+10$ L TFA, 300 K): $\delta=8.95$ (d, ${ }^{3} J=6.22 \mathrm{~Hz}, 1 \mathrm{H}, H-15$ ), 8.71 (d, ${ }^{3} J=4.89 \mathrm{~Hz}, 1 \mathrm{H}, H$-pyrrol), 8.65 (dd, ${ }^{3} J=7.50 \mathrm{~Hz},{ }^{4} J=1.04 \mathrm{~Hz}, 1 \mathrm{H}, H-3$ ), 8.56 (d, ${ }^{3} \mathrm{~J}=4.95 \mathrm{~Hz}, 1 \mathrm{H}$, $H$-pyrrol), 8.55 (d, ${ }^{3} J=4.95 \mathrm{~Hz}, 1 \mathrm{H}, H$-pyrrol), 8.52 (d, $1 \mathrm{H}, H$-pyrrol), 8.51 (s, $1 \mathrm{H}, H$-14'), 8.49 (d, ${ }^{3} J=4.76 \mathrm{~Hz}, 1 \mathrm{H}, H$-pyrrol), 8.18 (d, ${ }^{3} J=4.85 \mathrm{~Hz}, 1 \mathrm{H}, H$-pyrrol), 8.07 (td, ${ }^{3} J=7.56 \mathrm{~Hz},{ }^{4} J=1.31 \mathrm{~Hz}$, $\left.1 \mathrm{H}, H-4^{\prime}\right), 7.97\left(\mathrm{td},{ }^{3} J=7.56 \mathrm{~Hz},{ }^{4} J=1.22 \mathrm{~Hz}, 1 \mathrm{H}, H-5^{\prime}\right), 7.87$ (dd, $\left.{ }^{3} J=7.57 \mathrm{~Hz},{ }^{4} J=1.27 \mathrm{~Hz} .1 \mathrm{H}, H-6^{\prime}\right)$, 7.85 (d, ${ }^{3} J=6.87 \mathrm{~Hz}, 1 \mathrm{H}, H-16$ '), 7.49 (s, $1 \mathrm{H}, H-8$ ), 7.37 (d, ${ }^{3} J=7.86 \mathrm{~Hz}, 1 \mathrm{H}, H-10^{\prime}$ ), 7.10 (d, ${ }^{3} J=7.79 \mathrm{~Hz}, 1 \mathrm{H}, H-12$ ), 6.95 (t, $\left.{ }^{3} J=7.83 \mathrm{~Hz}, 1 \mathrm{H}, H-11^{\prime}\right), 6.41$ (d, ${ }^{3} J=6.85 \mathrm{~Hz}, 1 \mathrm{H}, H-3$ "), 6.03 (d, $\left.{ }^{3} J=6.56 \mathrm{~Hz}, 1 \mathrm{H}, H-6 "\right)$, 5.79-5.73 (m, 2H, H-4", $\left.H-5 "\right), 5.51$ (d, $\left.{ }^{3} J=5.64 \mathrm{~Hz}, 1 \mathrm{H}, H-1 "\right), 5.44$ (d, ${ }^{3} J=5.49 \mathrm{~Hz}, 1 \mathrm{H}, H-8$ "), 5.18 (dd, $\left.{ }^{3} J=9.44 \mathrm{~Hz},{ }^{4} J=5.63 \mathrm{~Hz}, 1 \mathrm{H}, H-3\right), 5.09$ (dd, ${ }^{3} J=9.44 \mathrm{~Hz}$, $\left.{ }^{4} J=5.61 \mathrm{~Hz}, 1 \mathrm{H}, H-2\right), 3.99$ (s, $1 \mathrm{H}, H-18$ ') ppm.

${ }^{13} \mathbf{C}\left\{{ }^{1} \mathrm{H}\right\}$ NMR (125 MHz, Aceton-d 6 + 10 HL TFA, 300 K): $\delta=169.0,152.6,145.0,143.1,143.0$, 142.8, 142.2, 139.7, 138.1, 136.6, 134.9, 133.5, 133.2, 131.4, 131.2, 130.7, 129.8, 129.7, 129.6, 129.1, 128.0, 126.4, 126.2, 124.4, 123.2, 120.1, 119.7, 112.4, 83.8, 83.4, 59.0, 55.7, 52.3 ppm, carbon atoms of the porphyrin and of the fluorinated meso substituents couldn't be detected due to low concentration.

${ }^{19}$ F NMR (470 MHz, Aceton-d $6+10 \mu \mathrm{L}$ TFA, 300 K): $\delta=-137.73\left(\mathrm{dd},{ }^{3} J=23.8 \mathrm{~Hz},{ }^{4} J=6.89 \mathrm{~Hz}\right.$, $1 F$, Por-Ar-o-F), -139.11 (dd, ${ }^{3} J=23.9 \mathrm{~Hz},{ }^{4} J=7.34 \mathrm{~Hz}, 1 \mathrm{~F}$, Por-Ar-o-F), -139.17 to -139.38 (m, 2F, Por-Ar-o-F), -139.87 (dd, ${ }^{3} J=23.7 \mathrm{~Hz},{ }^{4} \mathrm{~J}=6.20 \mathrm{~Hz}, 1 \mathrm{~F}$, Por-Ar-o-F), -139.98 (dd, ${ }^{3} J=23.7 \mathrm{~Hz}$, ${ }^{4} J=6.88 \mathrm{~Hz}, 1 \mathrm{~F}$, Por-Ar-o-F), -154.59 (t, ${ }^{3} J=20.7 \mathrm{~Hz}, 1 \mathrm{~F}$, Por-Ar-p-F), -154.80 to -155.04 (m, 2F, PorAr-p-F), -161.60 (td, ${ }^{3} J=22.1 \mathrm{~Hz},{ }^{4} J=7.93 \mathrm{~Hz}, 1 \mathrm{~F}$, Por-Ar-m-F), -162.37 (td, ${ }^{3} J=22.1 \mathrm{~Hz},{ }^{4} \mathrm{~J}=7.53$ Hz, 1F, Por-Ar-m-F), -163.14 to -163.40 (m, 2F, Por-Ar-m-F), -163.40 to -163.63 (m, 2F, Por-Ar-m-F) ppm.

MS (ESI-ToF, $\left.\mathrm{CHCl}_{3}\right): \mathrm{m} / \mathrm{z}(\%)=1270.1(77)[\mathrm{M}+\mathrm{H}]^{+}$.

HR MS (ESI-TOF, $\mathrm{CHCl}_{3}$ ): m/z [M+H] $]^{+}$calcd for $\mathrm{C}_{64} \mathrm{H}_{29} \mathrm{O}_{2} \mathrm{~N}_{7} \mathrm{~F}_{15}{ }^{58} \mathrm{Ni}$, 1270.1491; found 1270.1483 (-0.68 ppm).

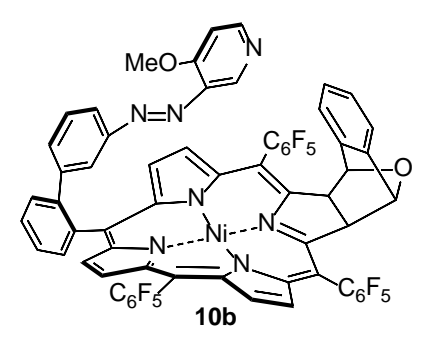

The Ni(II)chlorin precursor 6b-Ni (60.0 mg, 50.6 mol), 3-(3-bromophenylazo)-4-methoxypyridine (9) (22.2 mg, $75.9 \mu \mathrm{mol}), \mathrm{Pd}\left(\mathrm{PPh}_{3}\right)_{4}(8.00 \mathrm{mg}, 6.92 \mu \mathrm{mol})$ and potassium bicarbonate (24.5 mg, $177 \mu \mathrm{mol}$ ) were weighted out and were set under nitrogen. Toluene $(16 \mathrm{~mL})$, ethanol $(5 \mathrm{~mL})$ and water $(3.6 \mathrm{~mL})$ were added. The reaction mixture was stirred for $90 \mathrm{~h}$ at $40{ }^{\circ} \mathrm{C}$ in an oil bath. Ethyl acetate $(20 \mathrm{~mL})$ and water $(20 \mathrm{~mL})$ were added. The aqueous layer was extracted twice with ethyl acetate (each $20 \mathrm{~mL}$ ). 
The organic layer was dried over magnesium sulfate and evaporated to dryness. The crude product was purified via column chromatography on silica gel (cyclohexane/ethyl acetate, 3:2, $R_{\mathrm{f}}=0.26$ (trans), $R_{\mathrm{f}}$ $=0.71$ (cis)) and the desired product was obtained as green solid (16.9 mg, $13.3 \mu \mathrm{mol}, 26 \%$ ).

MS (ESI-ToF, $\left.\mathrm{CHCl}_{3}\right): \mathrm{m} / \mathrm{z}(\%)=1270.1(77)[\mathrm{M}+\mathrm{H}]^{+}$.

HR MS (ESI-TOF, $\mathrm{CHCl}_{3}$ ): $\mathrm{m} / \mathrm{z}[\mathrm{M}+\mathrm{H}]^{+}$calcd for $\mathrm{C}_{64} \mathrm{H}_{29} \mathrm{O}_{2} \mathrm{~N}_{7} \mathrm{~F}_{15}{ }^{58} \mathrm{Ni}, 1270.1491$; found 1270.1483 (-0.68 ppm).

There is only a NMR data analysis for 10a, because $\mathbf{1 0 b}$ is a mixture of two isomers (syn and anti) with a doubled data set in the spectrum with too much overlapping signals (cf. chapter VI).

\section{Synthesis of 5-(Biphenylazo-4-methoxypyridine)-10,15,20-tris(pentafluorophenyl)nickel(II)-}

\section{bacteriochlorin (11)}

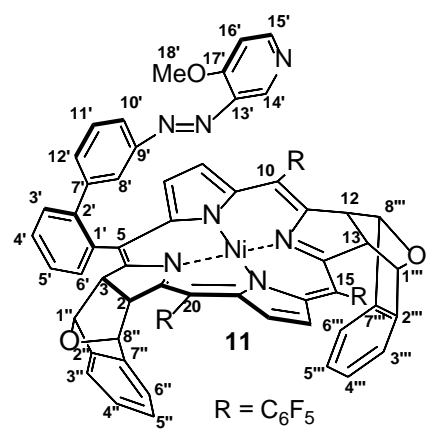

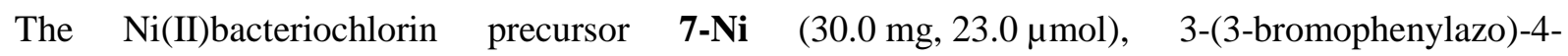
methoxypyridine (9) (10.1 mg, $34.5 \mu \mathrm{mol}), \mathrm{Pd}\left(\mathrm{PPh}_{3}\right)_{4}(8.00 \mathrm{mg}, 6.92 \mu \mathrm{mol})$ and potassium bicarbonate (11.1 mg, $80.5 \mu \mathrm{mol})$ were weighted out and were set under nitrogen. Toluene $(8 \mathrm{~mL})$, ethanol $(2.5 \mathrm{~mL})$ and water $(1.8 \mathrm{~mL})$ were added. The reaction mixture was stirred for $68 \mathrm{~h}$ at $40{ }^{\circ} \mathrm{C}$ in an oil bath. Ethyl acetate $(20 \mathrm{~mL})$ and water $(20 \mathrm{~mL})$ were added. The aqueous layer was extracted twice with ethyl acetate (each $20 \mathrm{~mL}$ ). The organic layer was dried over magnesium sulfate and evaporated to dryness. The crude product was purified via column chromatography on silica gel (cyclohexane/ethyl acetate, 3:2, $R_{\mathrm{f}}=0.14$ ) and the desired product was obtained as magenta solid (11.1 mg, $7.99 \mu \mathrm{mol}, 35 \%)$.

${ }^{1}$ H NMR (500 MHz, Aceton-d $\mathbf{d}_{6}+\mathbf{1 0} \boldsymbol{\mu L}$ TFA, 300 K): $\delta=8.07$ (br. s, $1 \mathrm{H}, H-15$ '), 7.98 (s, $1 \mathrm{H}$, $H$-pyrrol), 7.96 (d, ${ }^{3} J=4.85 \mathrm{~Hz}, 1 \mathrm{H}, H$-pyrrol), 7.88 (d, ${ }^{3} J=7.54 \mathrm{~Hz}, 1 \mathrm{H}, H-3$ '), 7.85 (d, ${ }^{3} J=7.45 \mathrm{~Hz}$, 1H, $H-6$ '), 7.75 (t, $\left.{ }^{3} J=7.53 \mathrm{~Hz}, 1 \mathrm{H}, H-4^{\prime}\right), 7.68$ (t, ${ }^{3} J=7.53 \mathrm{~Hz}, 1 \mathrm{H}, H-5$ '), 7.37 (s, 1H, $H-14$ '), 7.32 (t, ${ }^{3} J=7.49 \mathrm{~Hz}, 1 \mathrm{H}, H-5$ ') $) 7.30$ (t, ${ }^{3} J=7.45 \mathrm{~Hz}, 1 \mathrm{H}, H-5$ ', '), 7.25 (s, 2H, $H$-pyrrol, $H-8$ ') 7.17 (d, ${ }^{3} J=7.21 \mathrm{~Hz}, 1 \mathrm{H}, H-6$ '”'), 7.14 (d, ${ }^{3} J=7.27 \mathrm{~Hz}, 1 \mathrm{H}, H-6$ ') 7.12 (br. s, $1 \mathrm{H}, H-11$ '), 7.08 (br. S, $1 \mathrm{H}$, $H-16$ '), 6.87 (t, ${ }^{3} J=7.56 \mathrm{~Hz}, 1 \mathrm{H}, H-4$ ') $), 6.86$ (t, ${ }^{3} J=7.56 \mathrm{~Hz}, 1 \mathrm{H}, H-4$ ' ') $), 6.75$ (d, ${ }^{3} J=7.46 \mathrm{~Hz}, 1 \mathrm{H}$, $H$-3' ' '), 6.71 (d, ${ }^{3} J=7.38 \mathrm{~Hz}, 1 \mathrm{H}, H-3^{\text {'’ }), ~} 6.62$ (d, ${ }^{3} J=4.58 \mathrm{~Hz}, 1 \mathrm{H}, H$-pyrrol), 6.39 (br. s, $1 \mathrm{H}, H-10$ '), 5.28 (d, ${ }^{3} J=4.64 \mathrm{~Hz}, 1 \mathrm{H}, H-8$ ' ') $), 5.07$ (d, ${ }^{3} \mathrm{~J}=5.50 \mathrm{~Hz}, 1 \mathrm{H}, H-1$ '”), 5.04 (d, ${ }^{3} \mathrm{~J}=5.51 \mathrm{~Hz}, 1 \mathrm{H}, H-1$ ', '), 4.99 (d, ${ }^{3} J=4.63 \mathrm{~Hz}, 1 \mathrm{H}, H-8$ ') $), 4.85$ (br. s, $1 \mathrm{H}, H-12$ '), 4.16 (dd, ${ }^{3} J=7.58 \mathrm{~Hz}, 1 \mathrm{H}, H-12$ ), 4.10 (s, 3H, 
$H$-18'), 4.07 (dd, ${ }^{3} J=7.50 \mathrm{~Hz}, 1 \mathrm{H}, H-13$ ), 4.00 (dd, ${ }^{3} J=7.90 \mathrm{~Hz},{ }^{4} J=5.96 \mathrm{~Hz}, 1 \mathrm{H}, H-3$ ), 3.17 (dd, $\left.{ }^{3} J=7.92 \mathrm{~Hz},{ }^{4} \mathrm{~J}=4.81 \mathrm{~Hz}, 1 \mathrm{H}, H-2\right) \mathrm{ppm}$.

${ }^{13} \mathbf{C}\left\{{ }^{1} \mathbf{H}\right\}$ NMR (125 MHz, Aceton-d $\mathbf{d}_{6}+10 \mu \mathrm{L}$ TFA, 300 K): $\delta=158.1,157.4,154.2,141.8,139.8$, 139.6, 138.7, 138.6, 138.3, 136.8, 136.5, 135.5, 133.7, 133.1, 132.1, 130.6, 129.4, 128.6, 128.4, 128.1, 127.2, 126.3, 125.9, 124.0, 121.8, 121.3, 120.4, 119.9, 119.8, 113.0, 110.7, 106.4, 81.9, 81.7, 81.5, 81.5, 57.6, 55.5, 55.0, 48.2, $50.4 \mathrm{ppm}$, carbon atoms of the porphyrin and of the fluorinated meso substituents couldn't be detected due to low concentration.

${ }^{19}$ F NMR (470 MHz, CDCl $_{3}+10$ LL TFA, 300 K): $\delta=-134.77\left(\mathrm{~d},{ }^{3} \mathrm{~J}=19.7 \mathrm{~Hz}, 1 \mathrm{~F}\right.$, Por-Ar-oF), -136.19 (d, ${ }^{3} J=22.0 \mathrm{~Hz}, 1 \mathrm{~F}$, Por-Ar-o-F), -136.43 (d, ${ }^{3} J=17.1 \mathrm{~Hz}, 1 \mathrm{~F}$, Por-Ar-o-F), -136.71 (d, ${ }^{3} J$ $=22.0 \mathrm{~Hz}, 1 \mathrm{~F}$, Por-Ar-o-F), -139.28 (d, ${ }^{3} J=22.0 \mathrm{~Hz}, 2 \mathrm{~F}$, Por-Ar-o-F), -147.37 (t, ${ }^{3} J=20.6 \mathrm{~Hz}, 1 \mathrm{~F}$, PorAr-p-F), -147.81 (t, ${ }^{3} J=21.0 \mathrm{~Hz}, 1 \mathrm{~F}$, Por-Ar-p-F), -147.90 (t, ${ }^{3} J=19.7 \mathrm{~Hz}, 1 \mathrm{~F}$, Por-Ar-p-F), -159.66 (td, ${ }^{3} J=21.9 \mathrm{~Hz},{ }^{4} J=6.33 \mathrm{~Hz}, 1 \mathrm{~F}$, Por-Ar-m-F), -157.31 (td, ${ }^{3} J=21.5 \mathrm{~Hz},{ }^{4} J=6.96 \mathrm{~Hz}, 1 \mathrm{~F}$, Por-Ar-mF), -157.73 (td, ${ }^{3} J=21.1 \mathrm{~Hz},{ }^{4} J=6.98 \mathrm{~Hz}, 2 \mathrm{~F}$, Por-Ar-m-F), -158.29 (t, ${ }^{3} J=20.6 \mathrm{~Hz}, 1 \mathrm{~F}$, Por-Ar-mF), -158.55 (td, ${ }^{3} J=22.2 \mathrm{~Hz},{ }^{4} J=6.43 \mathrm{~Hz}, 1 \mathrm{~F}$, Por-Ar-m-F) ppm.

MS (ESI-ToF, $\left.\mathrm{CHCl}_{3}\right): \mathrm{m} / \mathrm{z}(\%)=1388.2(15)[\mathrm{M}+\mathrm{H}]^{+}$.

HR MS (ESI-TOF, $\mathrm{CHCl}_{3}$ ): $\mathrm{m} / \mathrm{z}[\mathrm{M}+\mathrm{H}]^{+}$calcd for $\mathrm{C}_{72} \mathrm{H}_{35} \mathrm{O}_{3} \mathrm{~N}_{7} \mathrm{~F}_{15}{ }^{58} \mathrm{Ni}$, 1388.1910; found 1388.1909 (-0.05 ppm). 


\section{I.2.7 Synthesis of Dendronized Record Players 12a, $12 b$ and 13}
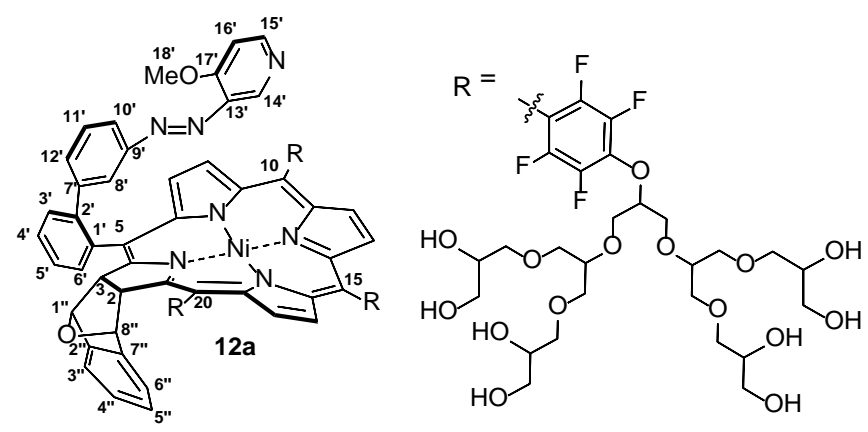

Glycerol dendrimer [G2.0]-OH (20.6 mg, $29.6 \mu \mathrm{mol})$ were added to a suspension of sodium hydride (60\% in mineral oil, $7.40 \mathrm{mg}, 185 \mu \mathrm{mol}$ ) in dry tetrahydrofuran. The mixture was stirred for $30 \mathrm{~min}$ at room temperature. Chlorin record player 10a $(7.70 \mathrm{mg}, 6.06 \mu \mathrm{mol})$ was added. The mixture was stirred $24 \mathrm{~h}$ at room temperature. Water $(20 \mathrm{~mL})$ was added. The aqueous layer was extracted three times with dichloromethane (each $40 \mathrm{~mL}$ ). The organic layer was dried over magnesium sulfate and evaporated to dryness. The crude product was purified via column chromatography on silica gel (dichloromethane/methanol, 97:3, $R_{\mathrm{f}}($ trans $)=0.32, R_{\mathrm{f}}($ cis $\left.)=0.36\right)$. The excess of glycerol dendron could not be removed this way. Therefore, deprotection was carried out subsequently. The dendronized record player was stirred at $30^{\circ} \mathrm{C}$ for 3 days in a mixture of methanol/acetic acid/water (2:2:1) in an oil bath. The solvent was removed under reduced pressure. The crude product containing still free glycerols was purified via ultrafiltration (Merck Millipore Cell with Ultrace ${ }^{\circledR}$ regenerated cellulose membrane, cut-off: $1000 \mathrm{~g} / \mathrm{mol}$, solvent: water) and the desired product was obtained as green oil $(12.0 \mathrm{mg}$, $4.25 \mu \mathrm{mol}, 70 \%)$.

${ }^{1}$ H NMR (600 MHz, MeOD + $20 \mu$ L TFA, 300 K): $\delta=9.20$ (br. s, $1 \mathrm{H}, H$-pyrrol), 9.15 (br. s, 1H, $H$-pyrrol), 9.07 (br. s, 1H, $H$-pyrrol), 9.05-8.99 (m, 2H, $H$-pyrrol, $H$-pyridine- $\mathrm{N}^{+}$, 8.98 (br. s, $1 \mathrm{H}$, $H$-pyrrol), 8.91 (d, ${ }^{3} J=4.32 \mathrm{~Hz}, 1 \mathrm{H}, H-14^{\prime}$ ), 8.61 (br. s, $1 \mathrm{H}, H$-pyrrol), 8.55 (d, ${ }^{3} J=7.29 \mathrm{~Hz}, 1 \mathrm{H}, H-3^{\prime}$ ), 8.51 (d, ${ }^{3} J=6.63 \mathrm{~Hz}, 1 \mathrm{H}, H-15$ '), 8.05-7.98 (m, 3H, $H-6$ ', $H-6$ ", $H-3$ "), 7.96-7.83 (m, 4H, $H-5$ ', $H-4$ ', $H$-5", $H-4$ "), 7.45 (d, ${ }^{3} J=7.12 \mathrm{~Hz}, 1 \mathrm{H}, H-12$ '), 7.35 (br. s, $1 \mathrm{H}, H-16$ '), 7.29 (br. s, $\left.1 \mathrm{H}, H-10^{\prime}\right), 7.12$ (br. s, 1H, $H-11$ '), 6.99 (br. s, 1H, $H-8$ '), 6.20 (br. s, $1 \mathrm{H}, H-1$ "), 5.94 (br. s, $1 \mathrm{H}, H-8$ "), 5.66 (br. s, 2H, $H-2$, $H$-3), 5.43-5.35 (m, 3H, $H-\mathrm{C}_{6} \mathrm{~F}_{4} \mathrm{O}-\mathrm{CH}$ ), 4.18-4.08 (m, 12H, $H-\mathrm{C}_{6} \mathrm{~F}_{4} \mathrm{O}-\mathrm{CH}\left(\mathrm{CH}_{2}\right)_{2}$ ), 3.95 (s, $1 \mathrm{H}, H-18$ ), 3.89-3.78 (m, 18H, H-glycerol), 3.76-3.45 (m, 72H, $H$-glycerol) ppm. (OH protons do not appear due to fast exchange)

${ }^{13} \mathbf{C}\left\{{ }^{1} \mathrm{H}\right\}$ NMR (125 MHz, MeOD + $20 \mu \mathrm{L}$ TFA, 300 K): $\delta=168.7,168.6,152.6,144.7,143.5,143.2$, 143.1, 142.5, 142.2, 142.1, 140.1, 138.3, 138.2, 137.0, 136.8, 135.5, 134.9, 134.1, 131.1, 130.8, 130.3 , 129.4, 126.7, 126.3, 122.1, 120.5, 119.7, 112.1, 83.3, 80.1, 74.0, 72.2, 72.0, 71.6, 64.5, 54.5 ppm, carbon atoms of the porphyrin and of the fluorinated meso substituents could not be detected due to low concentration. 
${ }^{19}$ F NMR (470 MHz, MeOD + $20 \mu \mathrm{L}$ TFA, 300 K): $\delta=-139.13$ (m, 1F, Por-Ar-o-F), -140.75 (d, ${ }^{3} J=$ 19.4 Hz, 2F, Por-Ar-o-F), -141.05 to -141.25 (m, 2F, Por-Ar-o-F), -141.65 (d, ${ }^{3} J=17.2 \mathrm{~Hz}, 1 \mathrm{~F}$, Por-Ar$o-F$ ), -154.78 to -154.87 (m, 1F, Por-Ar-m-F), -155.43 to -155.71 (m, 1F, Por-Ar-m-F), -155.91 to 155.99 (m, 1F, Por-Ar-m-F), -156.19 (br. s, 3F, Por-Ar-m-F) ppm.

HR MS (ESI-TOF, MeOH): m/z $[\mathrm{M}+\mathrm{Na}]^{2+}$ calcd for $\mathrm{C}_{127} \mathrm{H}_{157} \mathrm{O}_{47} \mathrm{~N}_{7} \mathrm{~F}_{12}{ }^{58} \mathrm{Ni}$, 1420.4585; found $1420.4609(+1.72 \mathrm{ppm})$.

MS (ESI-ToF, methanol): $\mathrm{m} / \mathrm{z}=1421.46[\mathrm{M}+2 \mathrm{H}+\mathrm{Na}]^{2+}$.
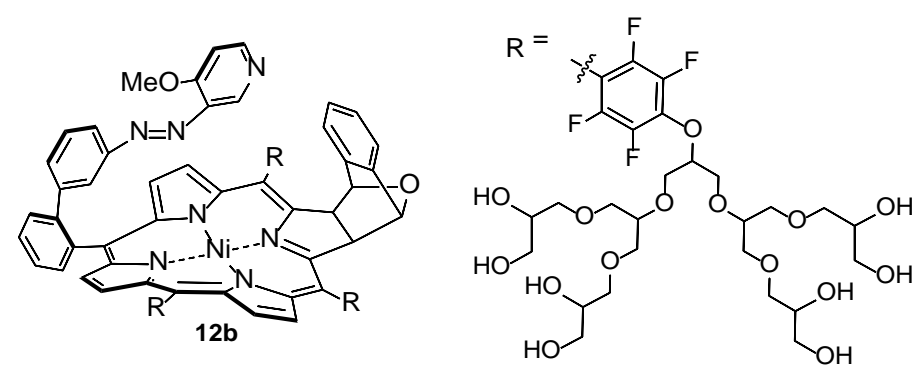

Glycerol dendrimer [G2.0]-OH $(27.1 \mathrm{mg}, 38.9 \mu \mathrm{mol})$ were added to a suspension of sodium hydride (60\% in mineral oil, $10.0 \mathrm{mg}, 250 \mu \mathrm{mol}$ ) in dry tetrahydrofuran. The mixture was stirred for $30 \mathrm{~min}$ at room temperature. Chlorin record player $10 \mathrm{~b}(10.9 \mathrm{mg}, 8.58 \mu \mathrm{mol})$ was added. The mixture was stirred $24 \mathrm{~h}$ at room temperature. Water $(20 \mathrm{~mL})$ was added. The aqueous layer was extracted three times with dichloromethane (each $40 \mathrm{~mL}$ ). The organic layer was dried over magnesium sulfate and evaporated to dryness. The crude product was purified via column chromatography on silica gel (dichloromethane/methanol, 97:3, $R_{\mathrm{f}}$ (trans) $=0.32, R_{\mathrm{f}}($ cis $)=0.37$ ). The excess of glycerol dendron could not be removed this way. Therefore, deprotection was carried out subsequently. The dendronized record player was stirred at $30^{\circ} \mathrm{C}$ for 3 days in a mixture of methanol/acetic acid/water (2:2:1) in an oil bath. The solvent was removed under reduced pressure. The crude product containing still free glycerols was purified via ultrafiltration (Merck Millipore Cell with Ultrace ${ }^{\circledR}$ regenerated cellulose membrane, cut-off: $1000 \mathrm{~g} / \mathrm{mol}$, solvent: water) and the desired product was obtained as green oil (16.7 mg, $5.92 \mu \mathrm{mol}, 69 \%)$.

MS (ESI-ToF, methanol): m/z = $1421.99[\mathrm{M}+2 \mathrm{H}+\mathrm{Na}]^{2+}$.

HR MS (ESI-TOF, MeOH): $\mathrm{m} / \mathrm{z}[\mathrm{M}+\mathrm{Na}]^{2+}$ calcd for $\mathrm{C}_{127} \mathrm{H}_{157} \mathrm{O}_{47} \mathrm{~N}_{7} \mathrm{~F}_{12}{ }^{58} \mathrm{Ni}, 1420.4585$; found 1420.4609 (+1.69 ppm).

There is only a NMR data analysis for 12a, because $\mathbf{1 2 b}$ is a mixture of two isomers (syn and anti) with a doubled data set in the spectrum with too much overlapping signals (cf. chapter VI). 

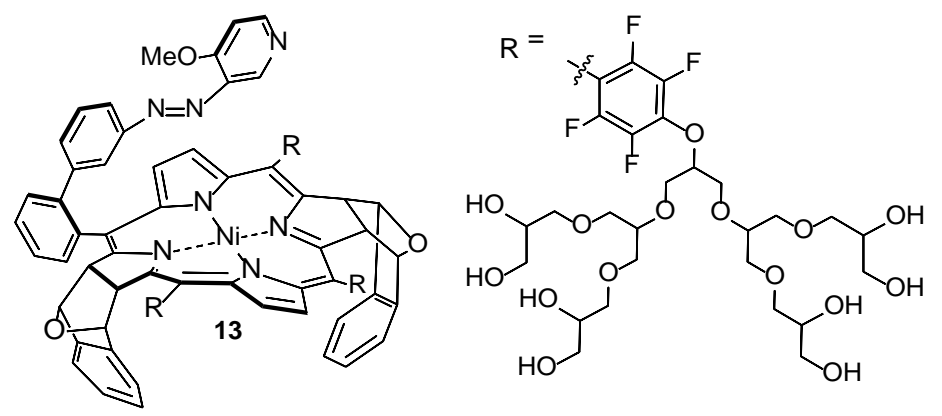

Glycerol dendrimer [G2.0]-OH (23.9 mg, $34.3 \mu \mathrm{mol})$ were added to a suspension of sodium hydride (60\% in mineral oil, $8.20 \mathrm{mg}, 205 \mu \mathrm{mol}$ ) in dry tetrahydrofuran. The mixture was stirred for $30 \mathrm{~min}$ at room temperature. Bacteriochlorin record player 11 (9.40 mg, $6.77 \mu \mathrm{mol})$ was added. The mixture was stirred $24 \mathrm{~h}$ at room temperature. Water $(20 \mathrm{~mL})$ was added. The aqueous layer was extracted three times with dichloromethane (each $40 \mathrm{~mL}$ ). The organic layer was dried over magnesium sulfate and evaporated to dryness. The crude product was purified via column chromatography on silica gel (dichloromethane/methanol, 97:3, $R_{\mathrm{f}}$ (trans) $=0.32, R_{\mathrm{f}}($ cis $)=0.37$ ). The excess of glycerol dendron could not be removed this way. Therefore, deprotection was carried out subsequently. The dendronized record player was stirred at $30^{\circ} \mathrm{C}$ for 3 days in a mixture of methanol/acetic acid/water (2:2:1) in an oil bath. The solvent was removed under reduced pressure. The crude product containing still free glycerols was purified via ultrafiltration (Merck Millipore Cell with Ultrace $l^{\circledR}$ regenerated cellulose membrane, cut-off: $1000 \mathrm{~g} / \mathrm{mol}$, solvent: water). After this, the crude product was purified via column chromatography on C18-silica gel (acetonitrile/water/methanol, 1:1:1, $R_{\mathrm{f}}=0.50$ ) and the desired product was obtained as a magenta oil ( $<0.500 \mathrm{mg}, 0.170 \mu \mathrm{mol},<3 \%)$.

The low yield can be explained by instability of bacteriochlorin record player $\mathbf{1 3}$ in solution (even at room temperature and under irradiation). Therefore, only a few UV-vis-absorption and mass spectra could be measured.

MS (ESI-ToF, methanol): m/z (\%) = $1479.48(20)[\mathrm{M}+\mathrm{Na}]^{2+}$. 


\section{UV-Vis Experiments}

\section{II.1 Extinction Coefficients of Platforms}

For determination of extinction coefficients UV-Vis spectra of compounds $\mathbf{6 a - N i , ~} \mathbf{6 b}-\mathbf{N i}$ and 7-Ni were measured at different concentrations in acetonitrile at $20^{\circ} \mathrm{C}$ (Fig. S5-S7). A comparison of the extinction coefficients is shown in Fig. S8.
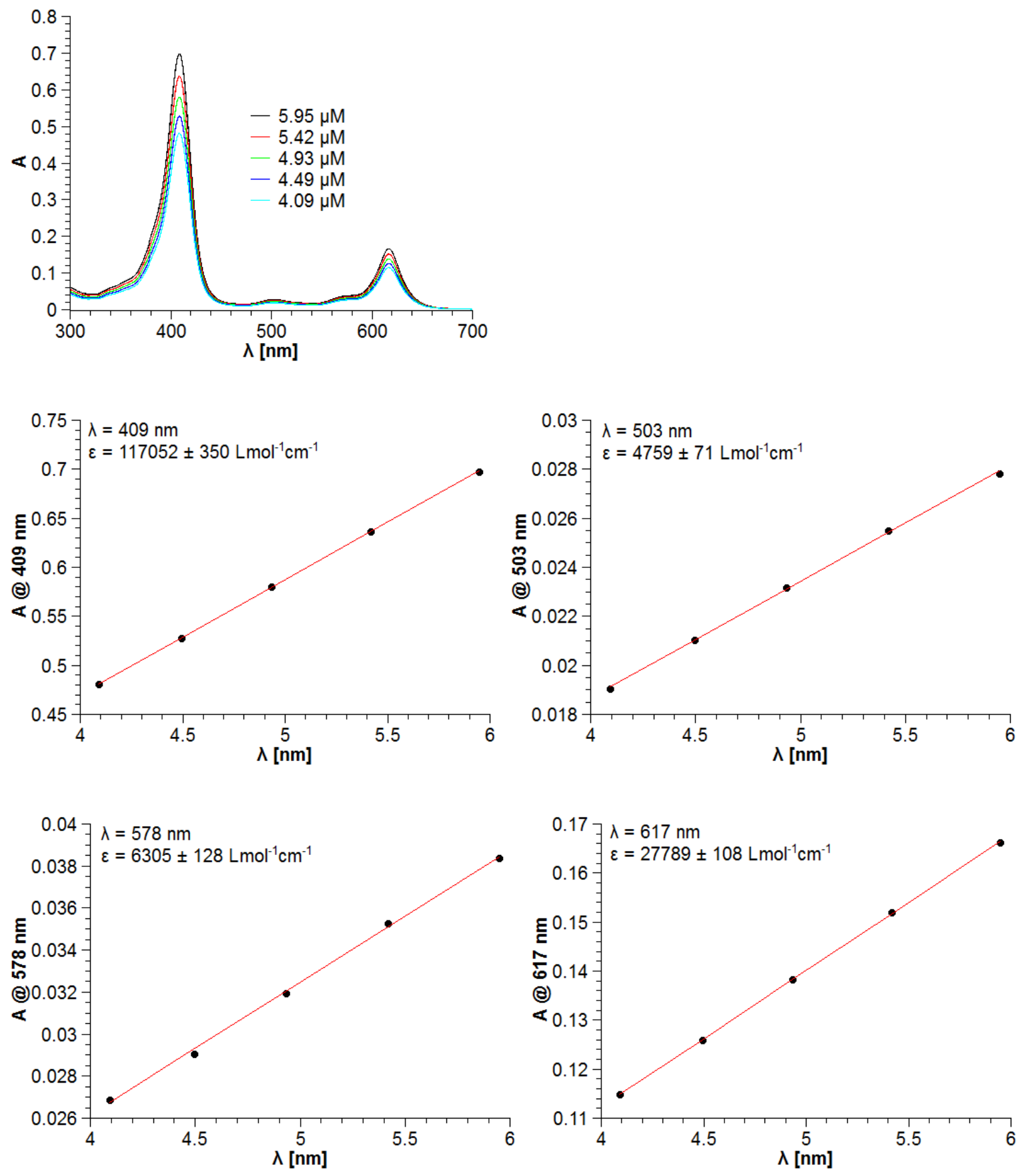

Fig. S5 UV-Vis spectra of 6a-Ni at different concentrations in acetonitrile (top) and extinction coefficients of the bands 409, 503, 578 and $617 \mathrm{~nm}$. 

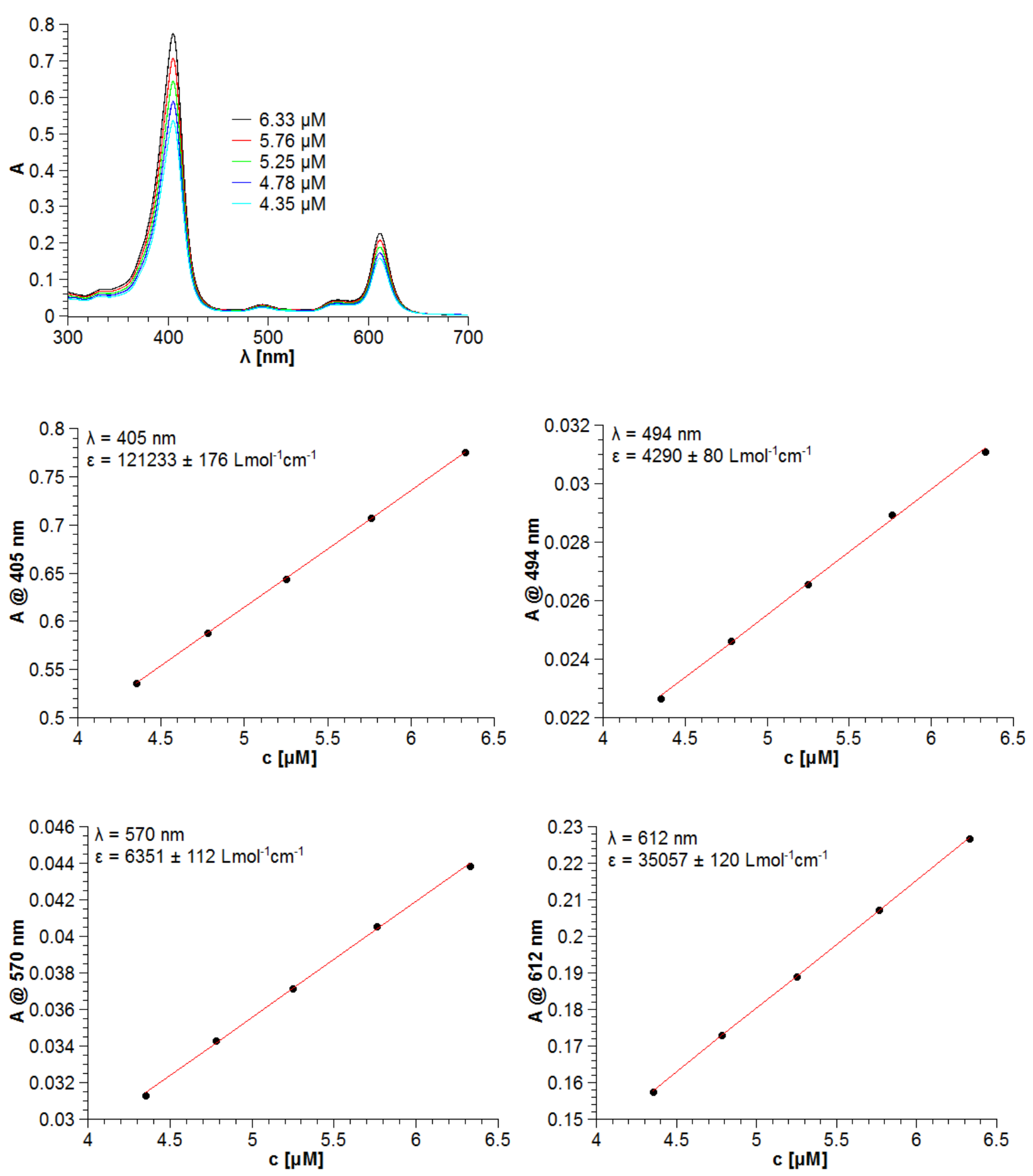

Fig. S6 UV-Vis spectra of $\mathbf{6 b}-\mathbf{N i}$ at different concentrations in acetonitrile (top) and extinction coefficients of the bands 405, 494, 570 and $612 \mathrm{~nm}$. 

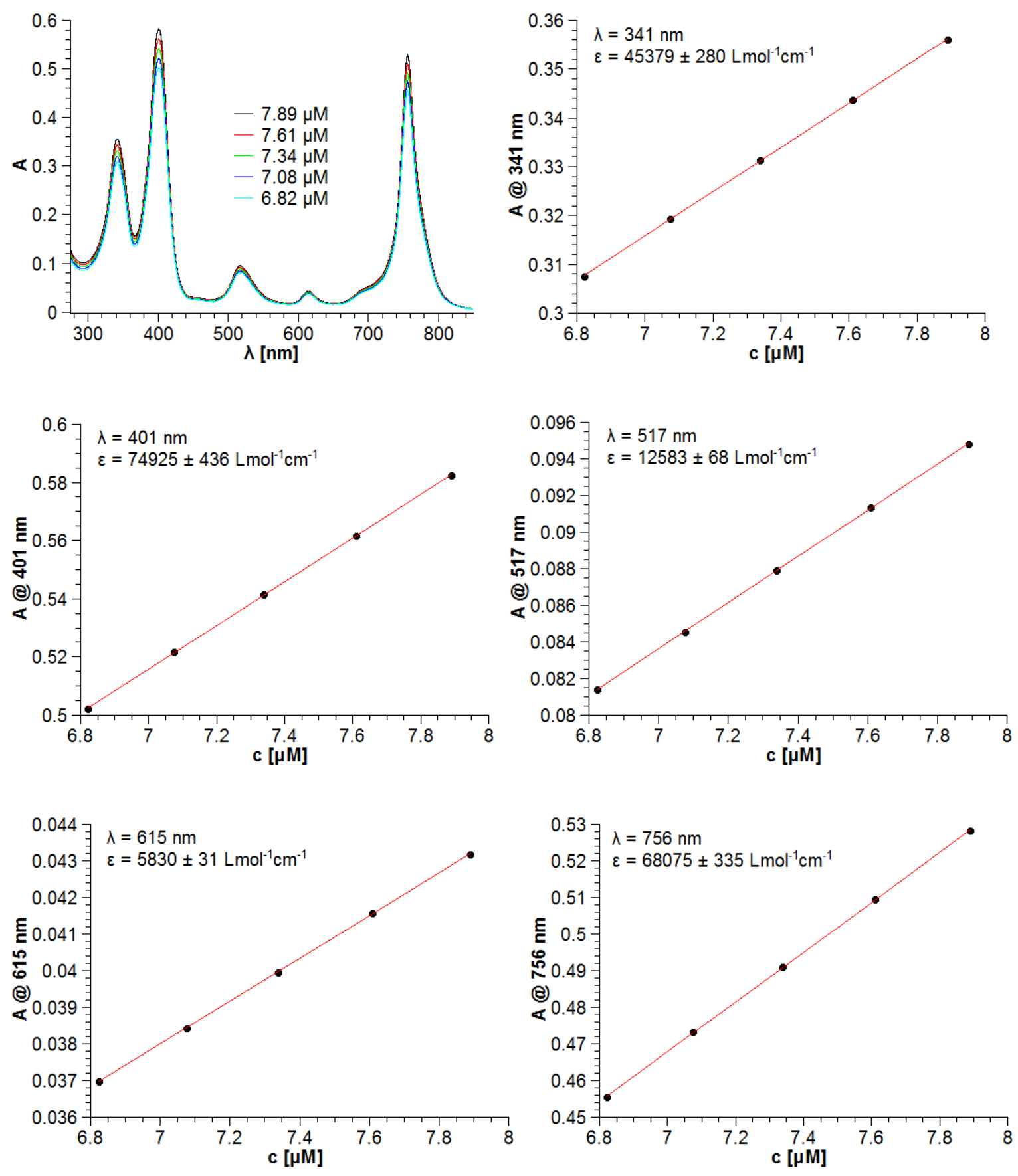

Fig. S7 UV-Vis spectra of 7-Ni at different concentrations in acetonitrile (top, left) and extinction coefficients of the bands 341, 401, 517, 615 and $756 \mathrm{~nm}$. 


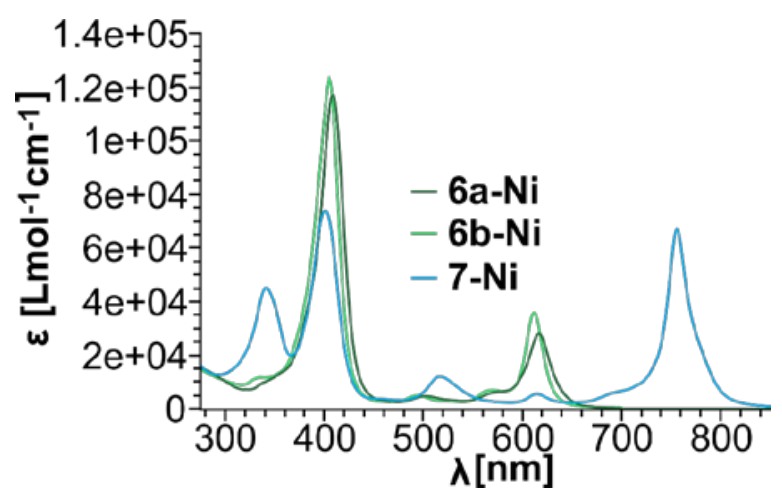

Fig. S8 Comparison of the extinction coefficients of the Ni(II) platforms $\mathbf{6 a}-\mathbf{N i}, \mathbf{6 b}-\mathbf{N i}$ and $7-\mathbf{N i}$ in acetonitrile at $20^{\circ} \mathrm{C}$. 


\section{II.2 Coordination-Induced Spin State Switch of Platforms and RPs with Piperidine}

Interesting for the switching behavior of the record player is the shift of the platforms's Q bands during addition of axial ligands. Upon coordination of piperidine the shift of the Q bands of the chlorins is negligible, while the $\mathrm{Q}$ band of the bacteriochlorins is clearly blue-shifted (Fig. S9).
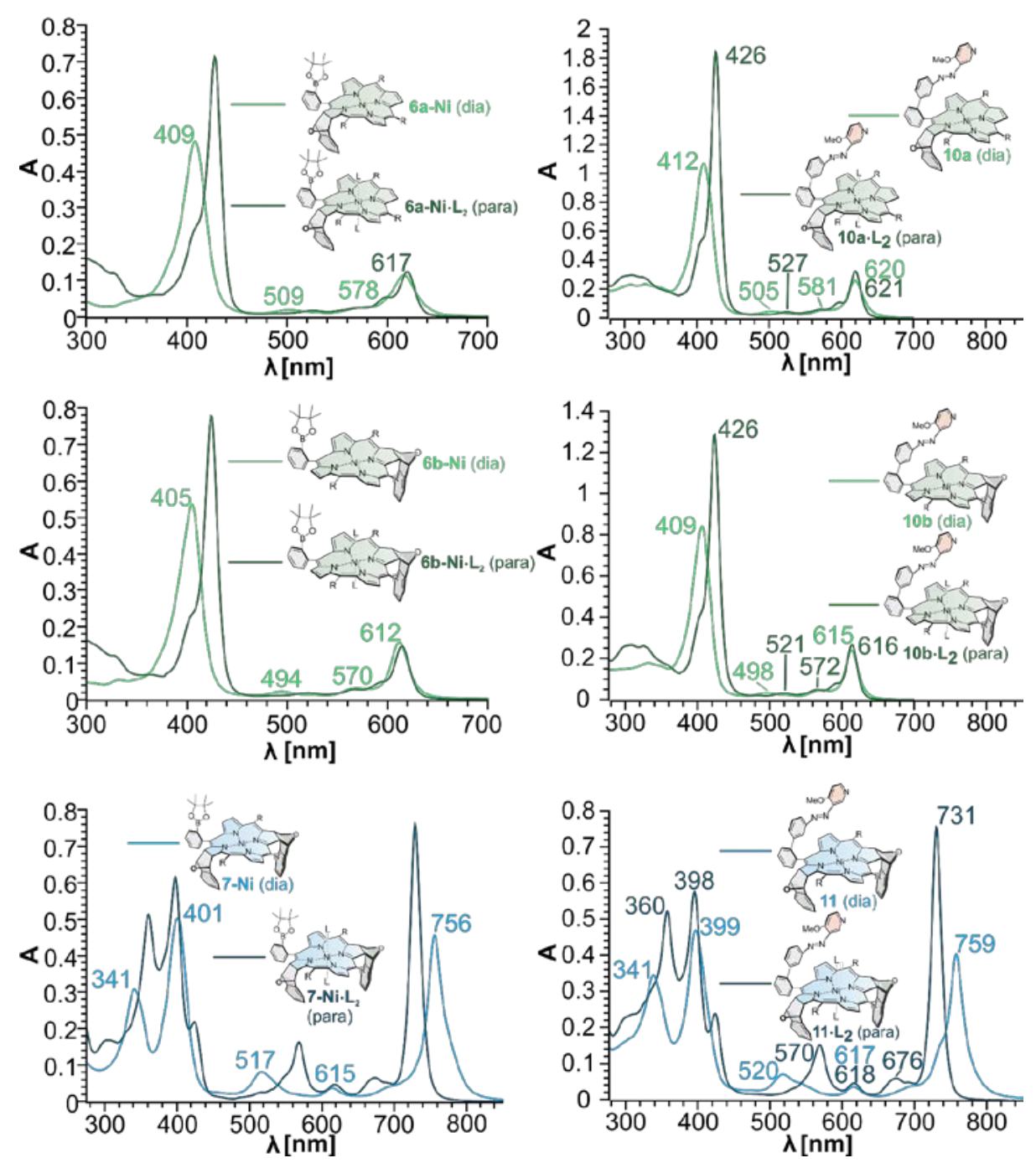

Fig. S9 UV-Vis spectra of the platforms (left: $\mathbf{6 a}-\mathbf{N i}, \mathbf{6 b}-\mathbf{N i}$ and 7-Ni) and of the record players (right: 10a, 10b and 11) in acetonitrile at $20^{\circ} \mathrm{C}$. Upon addition of piperidine (ligand L) the diamagnetic (dia) complexes become paramagnetic (para) and absorption bands are shifted $\left(\mathrm{R}=\mathrm{C}_{6} \mathrm{~F}_{5}\right)$. 


\section{II.3 Switching of Record Players}

Switching experiments were carried out to investigate the switching behavior of compounds 10a, 10b and $\mathbf{1 1}$ in acetonitrile or acetone. While the best wavelength for 'on switching' is $505 \mathrm{~nm}$ for all record players, their 'off switching' wavelengths differ (420 and $620 \mathrm{~nm}$ for chlorin RP 10a and 10b; 385 and $720 \mathrm{~nm}$ for the bacteriochlorin RP 11, Fig. S10).
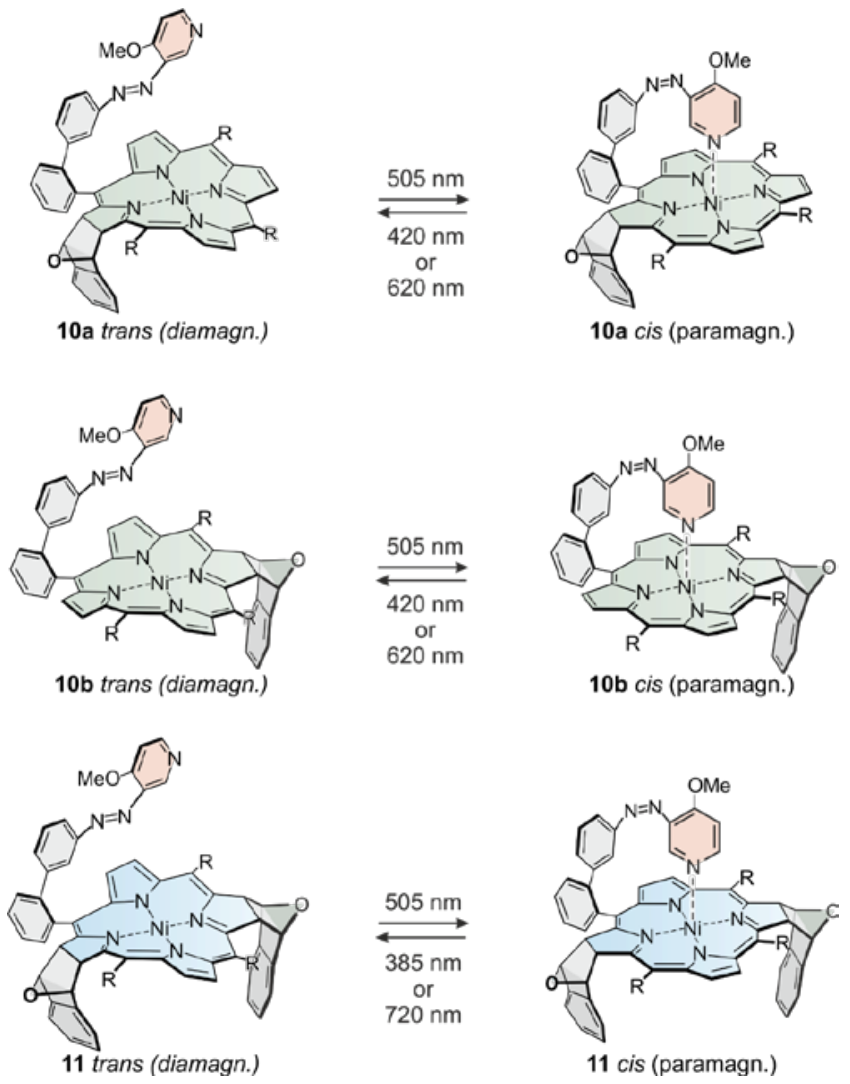

Fig. S10 Best switching wavelengths for record players 10a (top), 10b (mid) and 11 (bottom) based on UV-vis data in acetonitrile and acetone. Upon irradiation with green light the paramagnetic cis isomers (right) are formed. Blue or red light isomerizes the record player back to its trans configuration (left) $\left(\mathrm{R}=\mathrm{C}_{6} \mathrm{~F}_{5}\right)$.

The following Fig. S11-S13 show the UV-vis spectra of the switching behavior of compounds 10a, 10b and $\mathbf{1 1}$ after irradiation with blue, green and red light and after addition of piperidine (paramagnetic square pyramidal or square bipyramidal complex) or trifluoroacetic acid (TFA, diamagnetic square planar complex) in acetone at $25^{\circ} \mathrm{C}$. The spectra with addition of TFA reveal that after irradiation with blue light $\sim 5-10 \%$ of the paramagnetic species are left, which can either be attributed to an incomplete cis-to-trans isomerisation or to an intermolecular coordination behavior, where the trans azopyridine coordinates to a nickel ion of a second record player molecule due to higher association constants (cf. chapter III). 

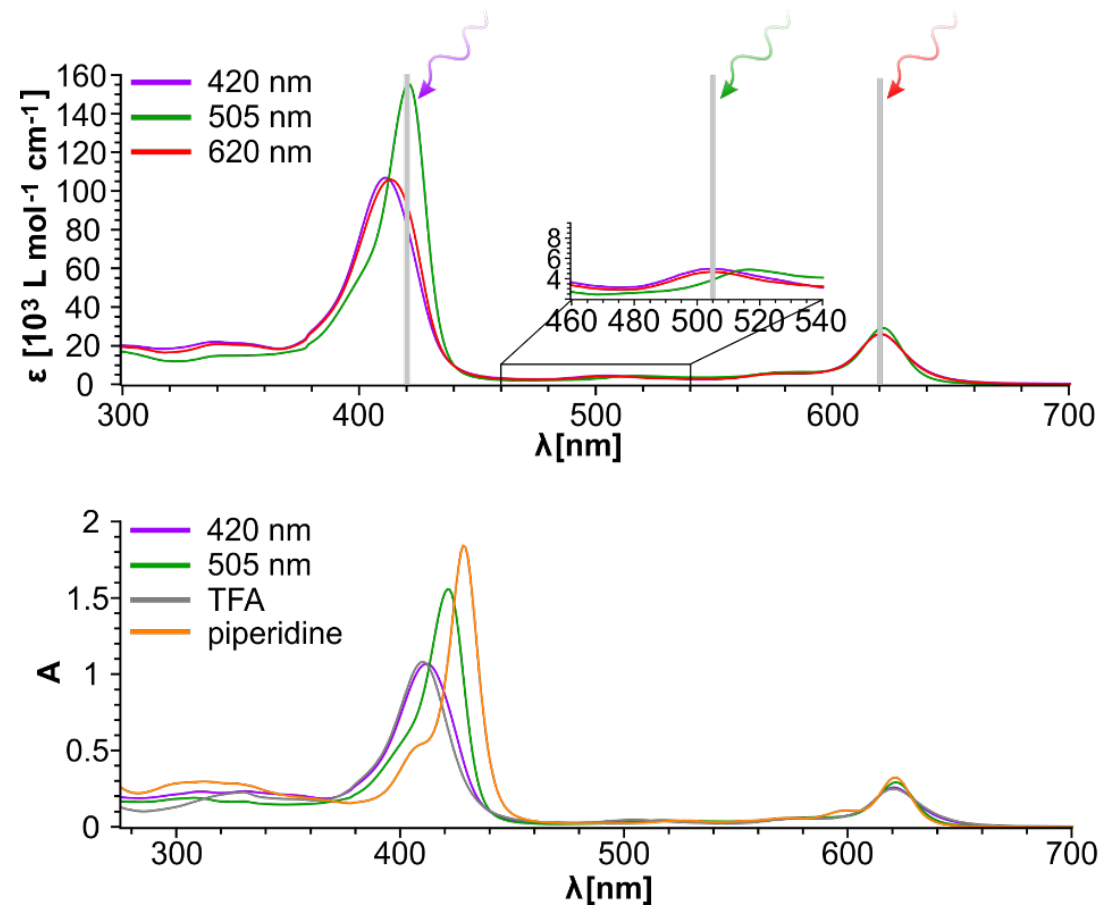

Fig. S11 UV-vis spectra of 10a in acetone at $25^{\circ} \mathrm{C}$ after irradiation with blue $(420 \mathrm{~nm})$, green $(505 \mathrm{~nm})$ and red (620 nm) light (top) in comparison to addition of TFA and piperidine (bottom).
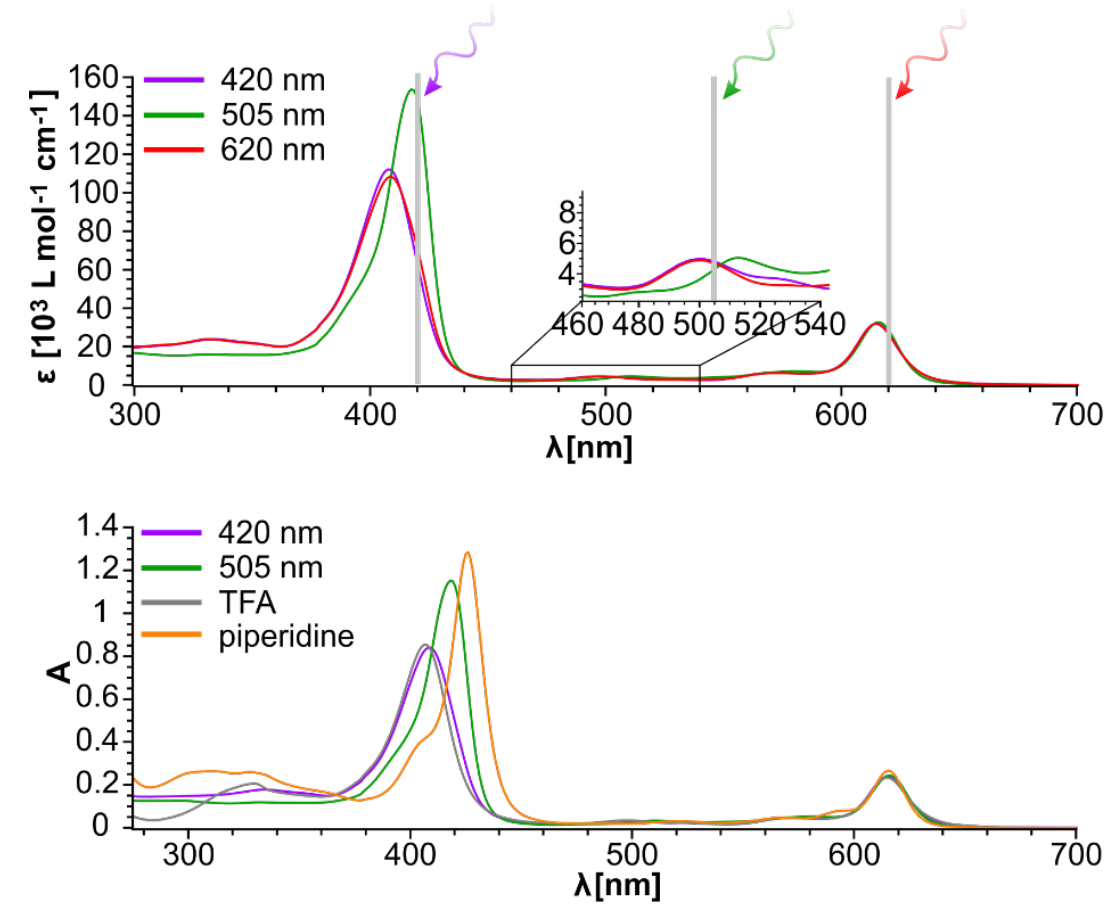

Fig. S12 UV-vis spectra of $\mathbf{1 0 b}$ in acetone at $25^{\circ} \mathrm{C}$ after irradiation with blue $(420 \mathrm{~nm})$, green $(505 \mathrm{~nm})$ and red (620 nm) light (top) in comparison to addition of TFA and piperidine (bottom). 

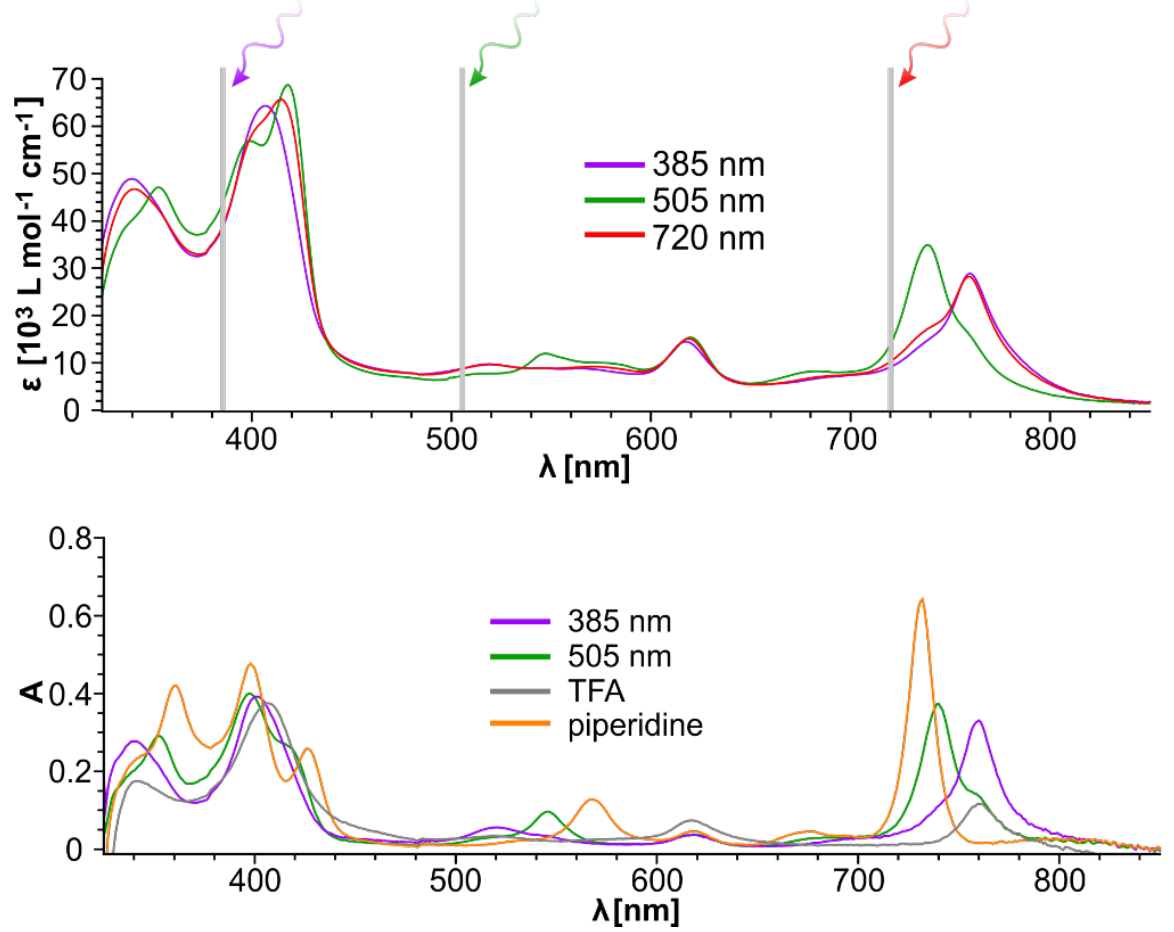

Fig. S13 UV-vis spectra of 11 in acetone at $25^{\circ} \mathrm{C}$ after irradiation with blue $(420 \mathrm{~nm})$, green $(505 \mathrm{~nm})$ and red (720 nm) light (top) in comparison to addition of TFA and piperidine (bottom). 
The following figures show the switching behavior of the dendronized record players 12a, $\mathbf{1 2 b}$ and 13 in water and methanol (Fig. S14-S19). Due to instability of bacteriochlorin record player $\mathbf{1 3}$ in solution (degradation to chlorin RP, even at room temperature and under irradiation) only a few absorption spectra could be measured.
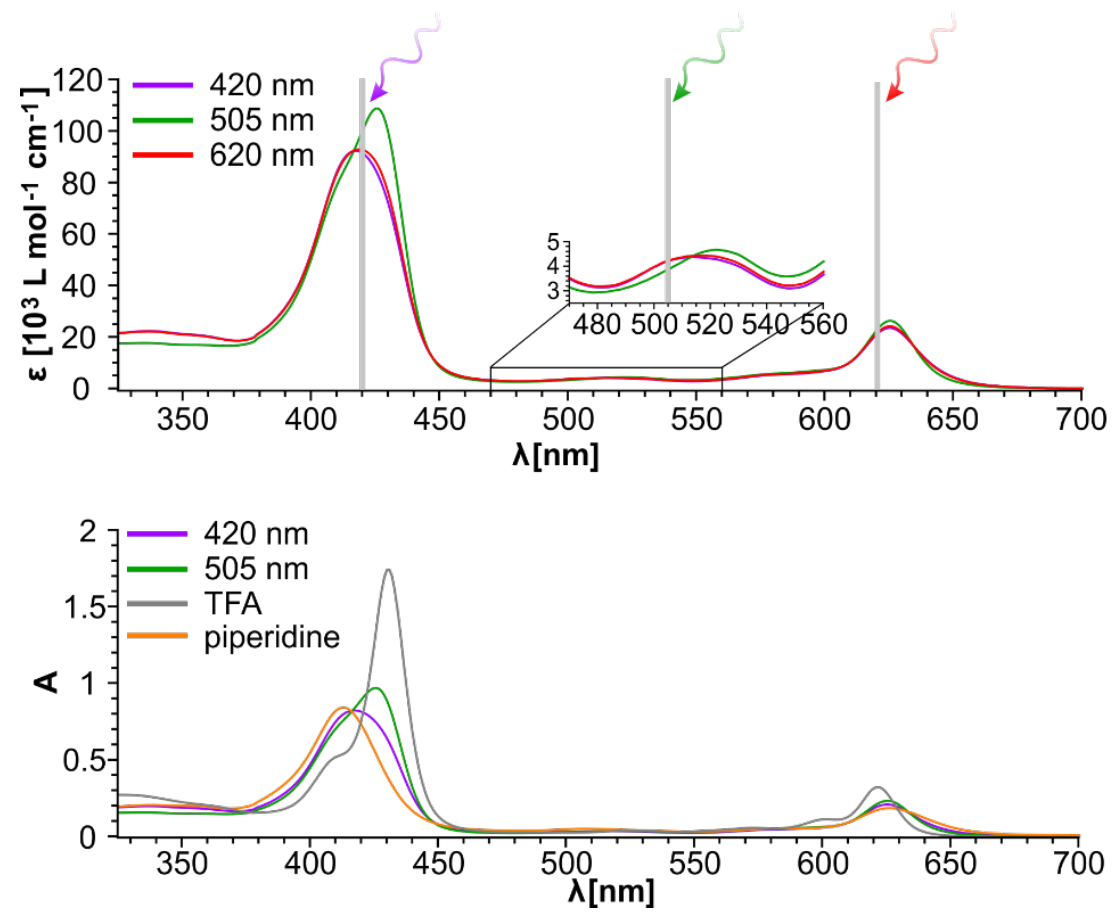

Fig. S14 UV-vis spectra of 12a in water at $25^{\circ} \mathrm{C}$ after irradiation with blue $(420 \mathrm{~nm})$, green $(505 \mathrm{~nm})$ and red (620 nm) light (top) in comparison to addition of TFA and piperidine (bottom).
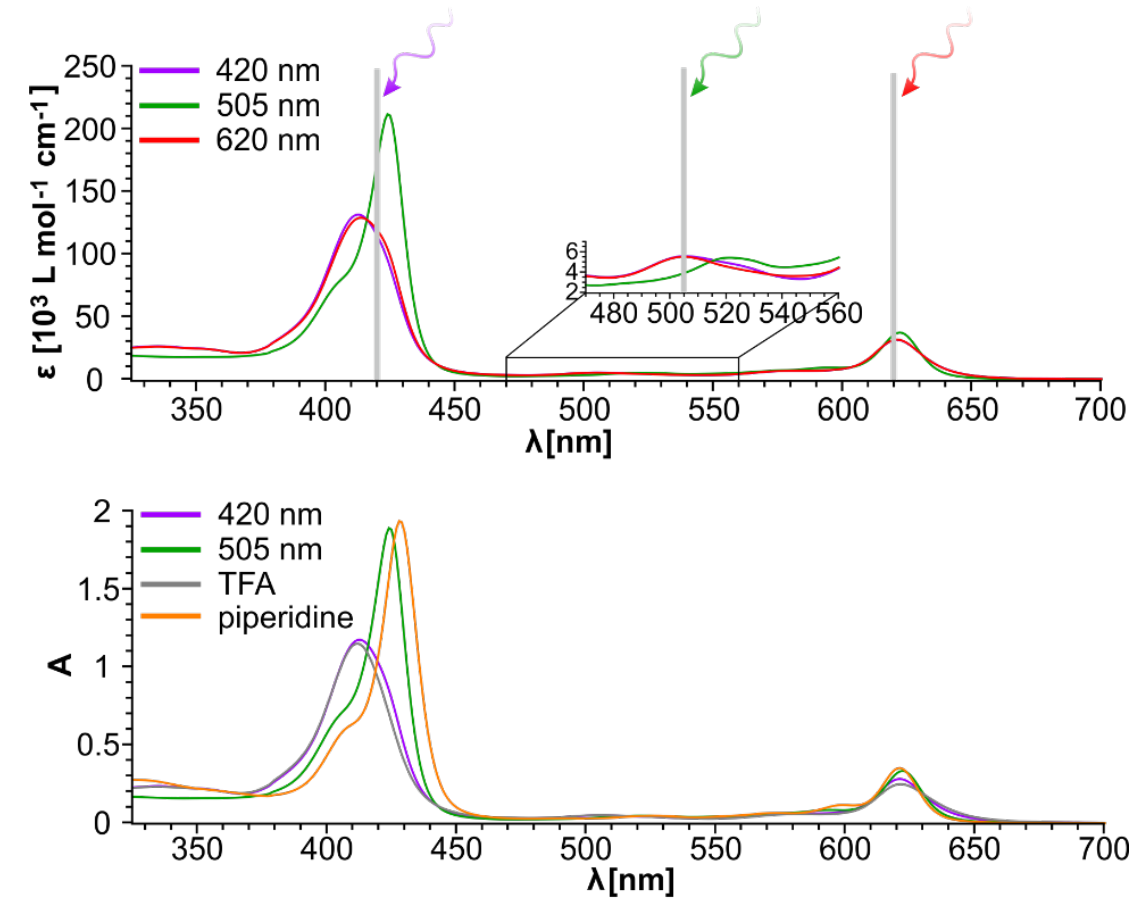

Fig. S15 UV-vis spectra of 12a in methanol at $25^{\circ} \mathrm{C}$ after irradiation with blue (420 nm), green (505 nm) and red (620 nm) light (top) in comparison to addition of TFA and piperidine (bottom). 

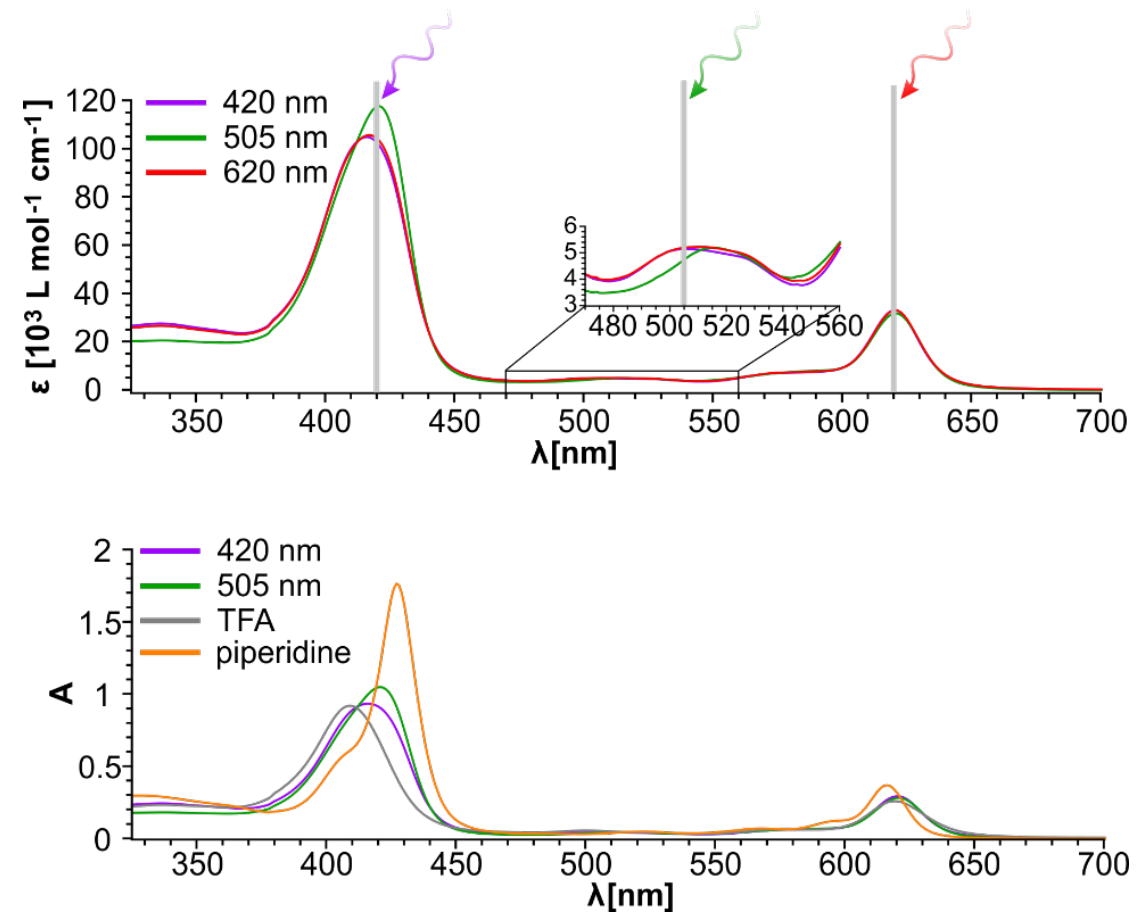

Fig. S16 UV-vis spectra of $\mathbf{1 2 b}$ in water at $25^{\circ} \mathrm{C}$ after irradiation with blue $(420 \mathrm{~nm})$, green $(505 \mathrm{~nm})$ and red (620 nm) light (top) in comparison to addition of TFA and piperidine (bottom).
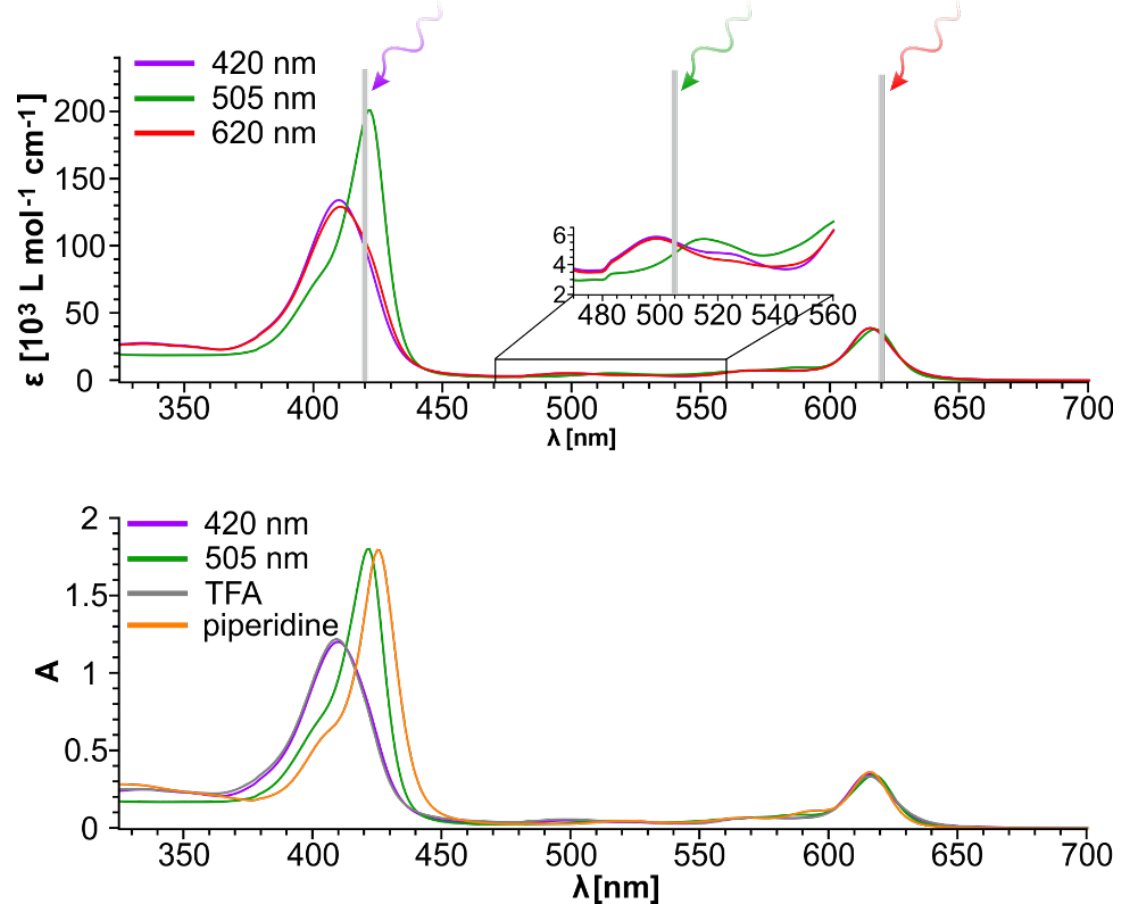

Fig. S17 UV-vis spectra of $\mathbf{1 2 b}$ in methanol at $25^{\circ} \mathrm{C}$ after irradiation with blue (420 nm), green (505 nm) and red (620 nm) light (top) in comparison to addition of TFA and piperidine (bottom). 

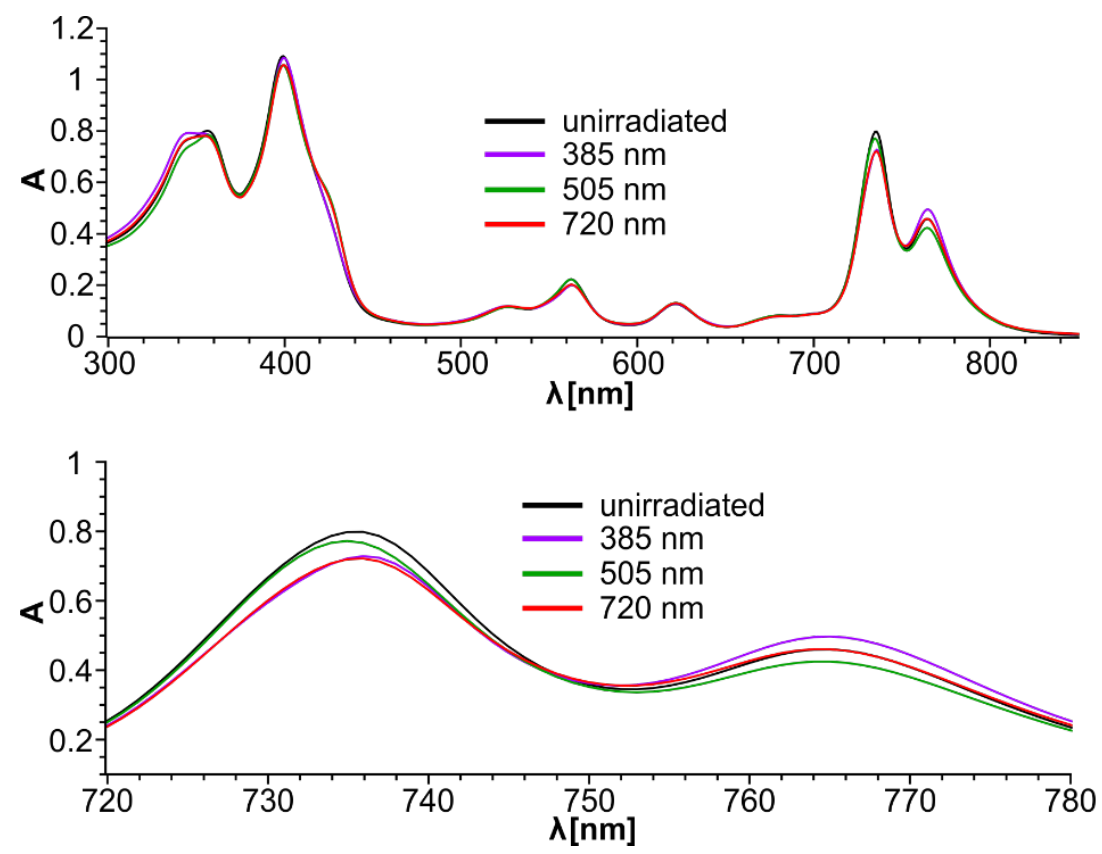

Fig. S18 UV-vis spectra of 13 in water at $25^{\circ} \mathrm{C}$ after irradiation with blue (385 nm), green (505 nm) and red (720 nm) light. Zooming into the Q band region (bottom) show a relatively small switching behavior in water, the bacteriochlorin record player is mostly paramagnetic due to coordination of the solvent. Hence, the water-soluble bacteriochlorin record player $\mathbf{1 3}$ is not suitable for switching experiments. It also shows a relatively fast degradation to the chlorin record player.
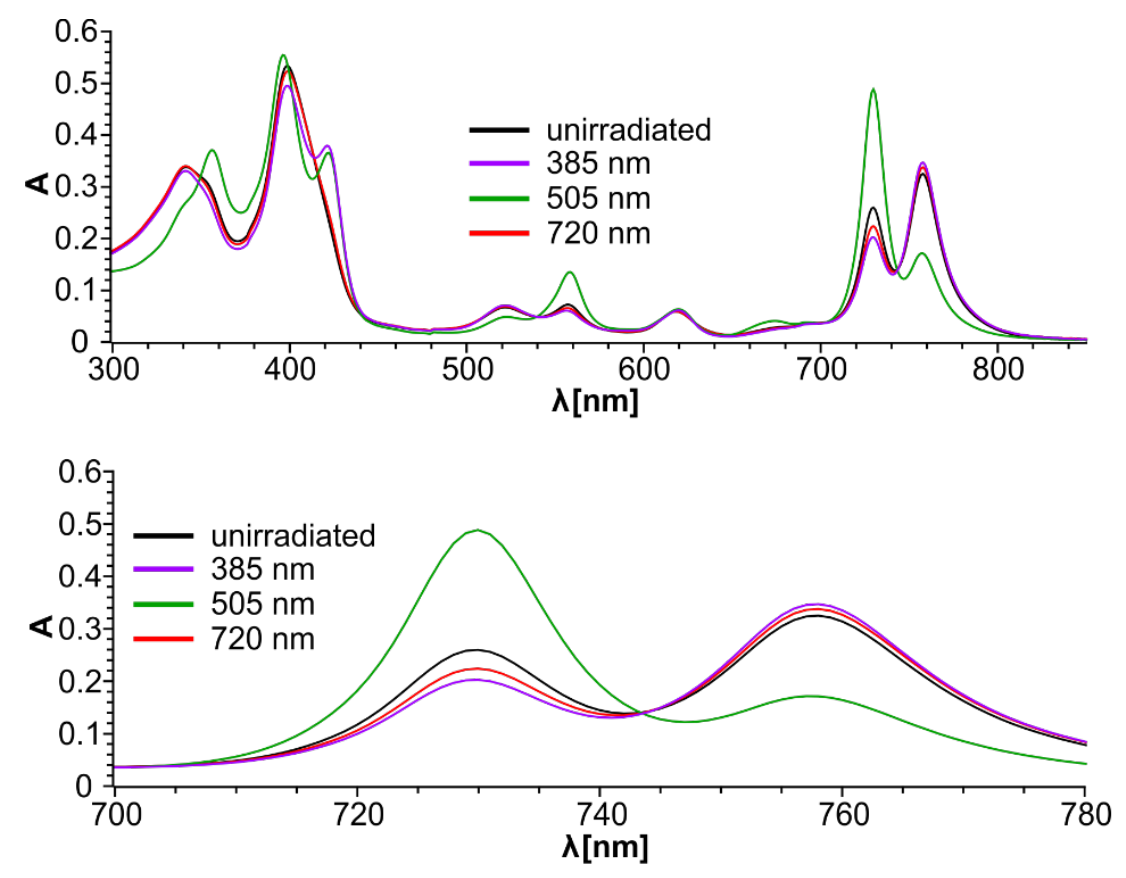

Fig. S19 UV-vis spectra of 13 in methanol at $25^{\circ} \mathrm{C}$ after irradiation with blue (385 nm), green (505 nm) and red $(720 \mathrm{~nm})$ light. Zooming into the $\mathrm{Q}$ band region (bottom) show a better switching behavior in methanol compared to water, but also methanol seems to coordinate to the Ni(II) ion. 


\section{II.4 Long-term Switching Stability of Record Players}

Fatigue experiments were carried out to prove the long-term switching stability of compounds 10a, 10b, 11, 12a and 12b. Measurements were carried out with an in-house built light source with 420 and $505 \mathrm{~nm}$ for the chlorin record players 10a, 10b, 12a and 12b and with a light source with $385 \mathrm{~nm}$ and $505 \mathrm{~nm}$ for the bacteriochlorin record player 11. First, the sample was switched to its "off" state by irradiation with $420 \mathrm{~nm}$ for two minutes (chlorin RP 10a, 10b, 12a and 12b) or with $385 \mathrm{~nm}$ for two minutes (bacteriochlorin RP 11). Then the light source was switched to $505 \mathrm{~nm}$ for two minutes (4 minutes per cycle). In total 100 cycles were measured (Fig. S20-S24). The chlorin record player 10a and 10b showed no fatigue, while bacteriochlorin record player 11 lost $13 \%$ of its switching efficiency after 100 cycles. The switching behavior of the dendronized chlorin record players $12 \mathbf{a}$ and $\mathbf{1 2} \mathbf{b}$ decreased only by 1-2 \% after 100 cycles.
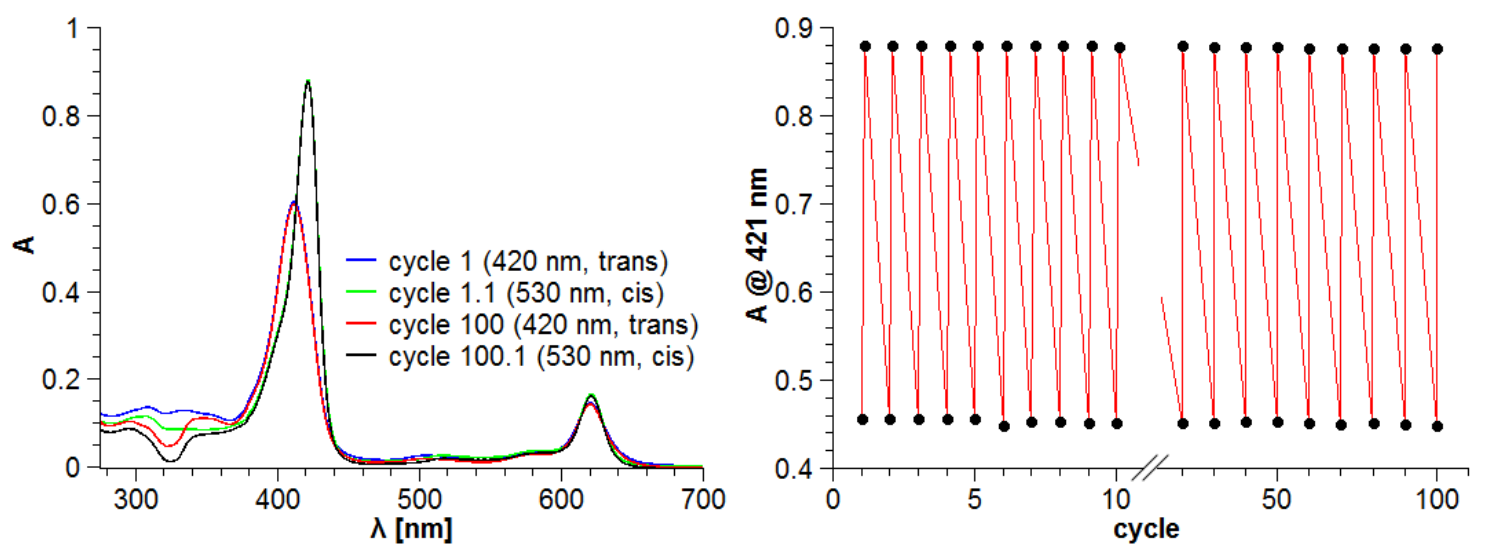

Fig. S20 UV-vis spectra at the start (cycle 1) and after the 100th cycle (left) and the absorption at $421 \mathrm{~nm}$ after several cycles (right) of $\mathbf{1 0 a}$ in acetonitrile at $25^{\circ} \mathrm{C}$.
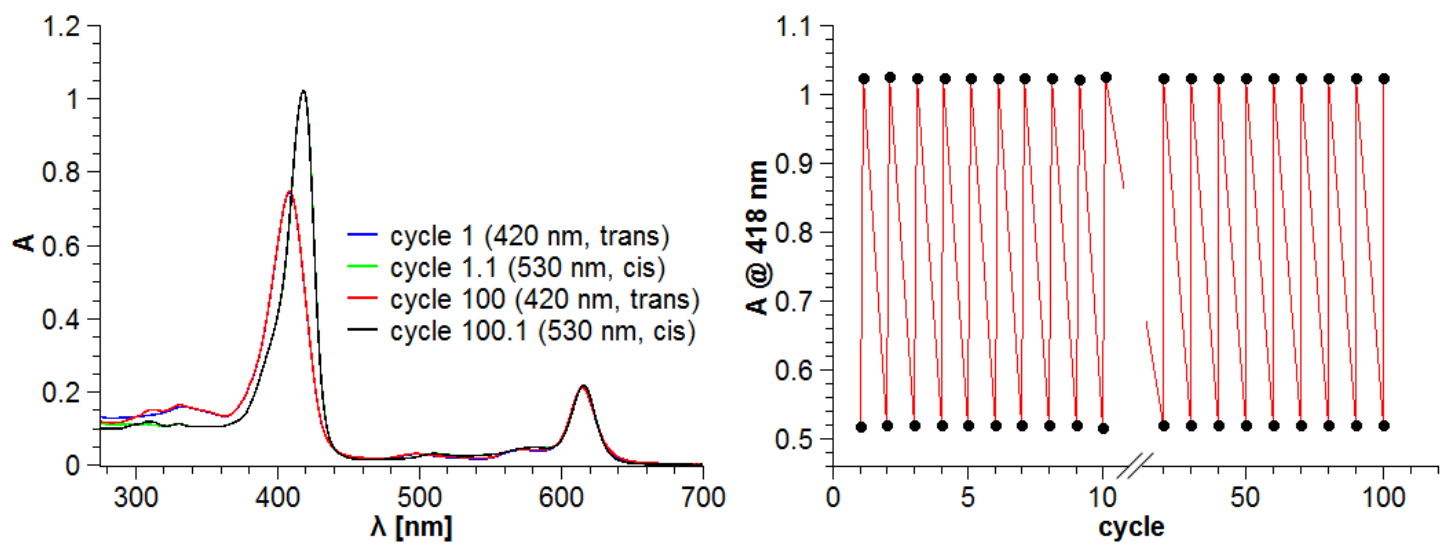

Fig. S21 UV-vis spectra at the start (cycle 1) and after the 100th cycle (left) and the absorption at $418 \mathrm{~nm}$ after several cycles (right) of $\mathbf{1 0 b}$ in acetonitrile at $25^{\circ} \mathrm{C}$. 

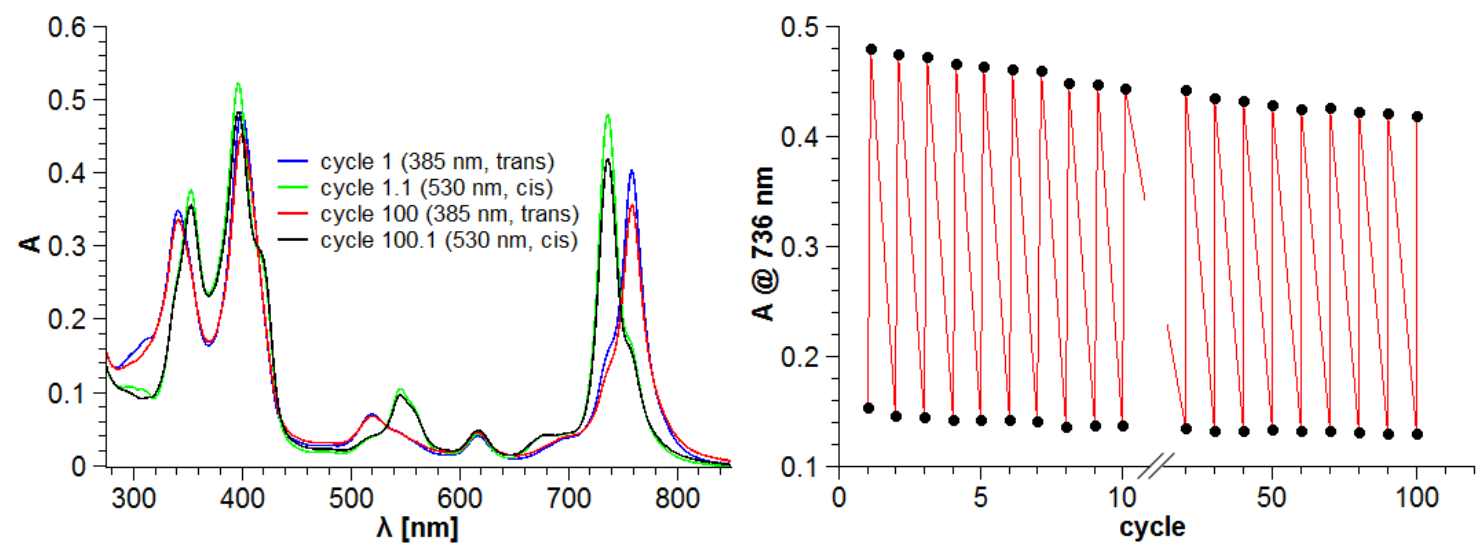

Fig. S22 UV-vis spectra at the start (cycle 1) and after the 100th cycle (left) and the absorption at $736 \mathrm{~nm}$ after several cycles (right) of $\mathbf{1 1}$ in acetonitrile at $25^{\circ} \mathrm{C}$.
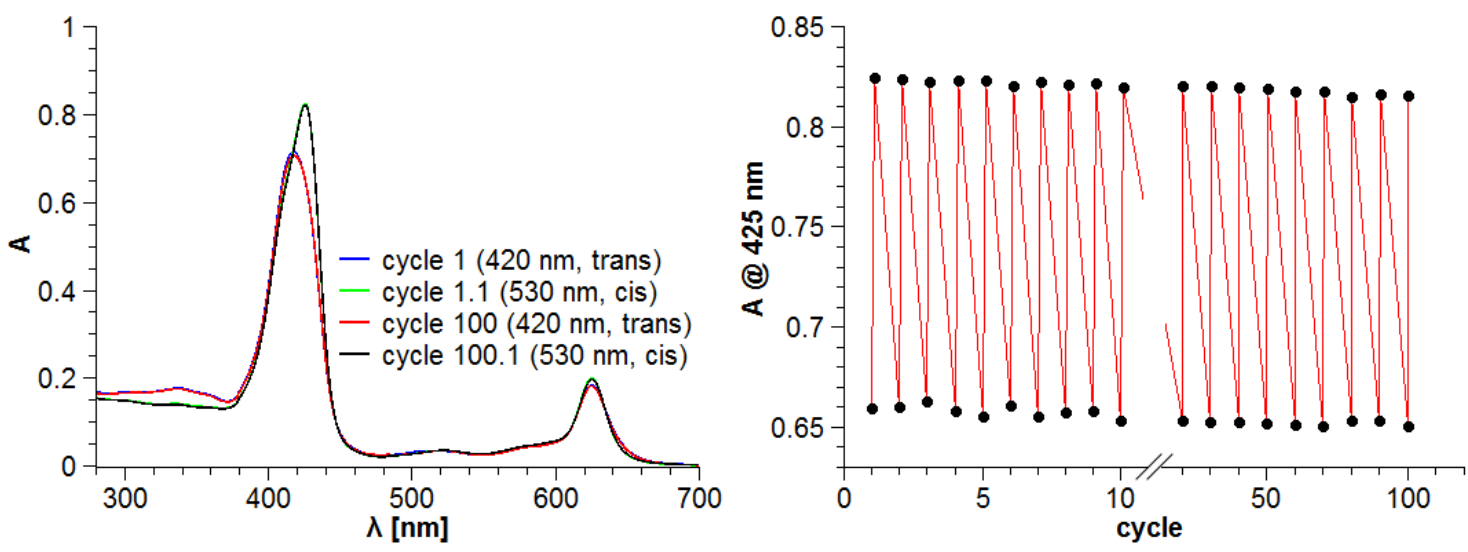

Fig. S23 UV-vis spectra at the start (cycle 1) and after the 100th cycle (left) and the absorption at $425 \mathrm{~nm}$ after several cycles (right) of 12a in water at $25^{\circ} \mathrm{C}$.
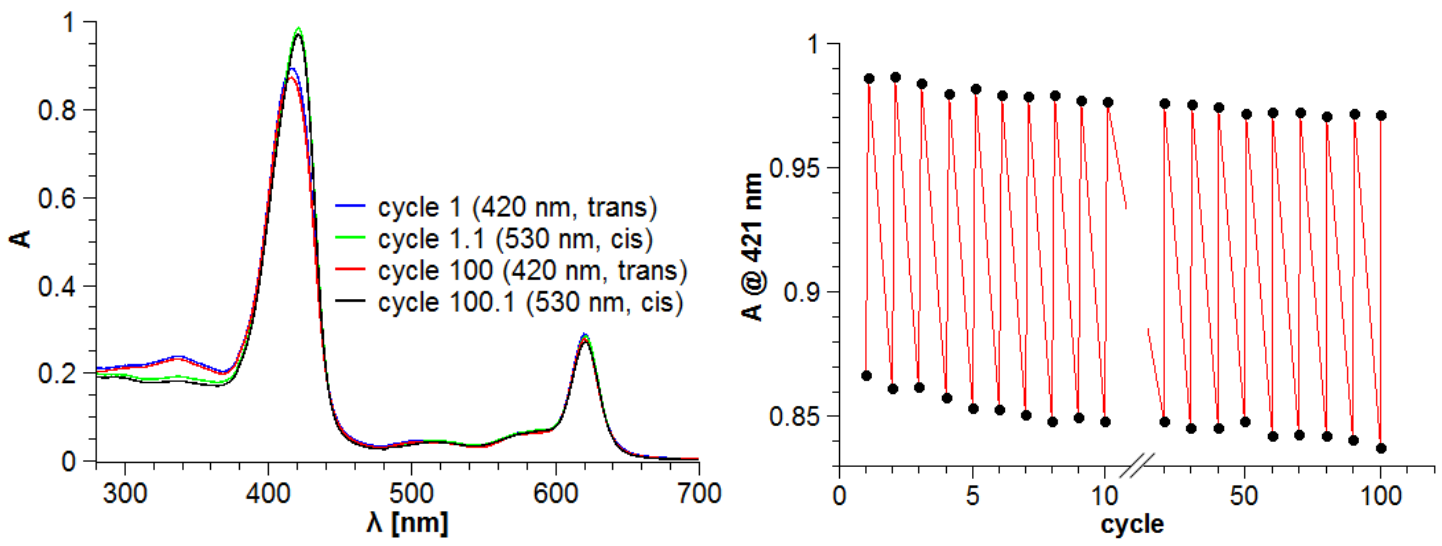

Fig. S24 UV-vis spectra at the start (cycle 1) and after the 100th cycle (left) and the absorption at $421 \mathrm{~nm}$ after several cycles (right) of $\mathbf{1 2 b}$ in water at $25^{\circ} \mathrm{C}$. 


\section{II.5 Thermal Half-lifes of Record Players}

For determination of half-lifes at $25^{\circ} \mathrm{C}$ compounds 10a, 10b and 11 were solved in acetonitrile and filled in a $1 \mathrm{~cm}$ cuvette. The samples were irradiated with green light $(505 \mathrm{~nm})$ for five minutes and the measurement was started immediately. In several time intervals $(\Delta t=15 \mathrm{~min})$ the absorption of the record player's paramagnetic absorption bands was detected. At room temperature no isomerization behavior could be observed. Therefore, temperature was increased to $37^{\circ} \mathrm{C}$ (Fig. S25).
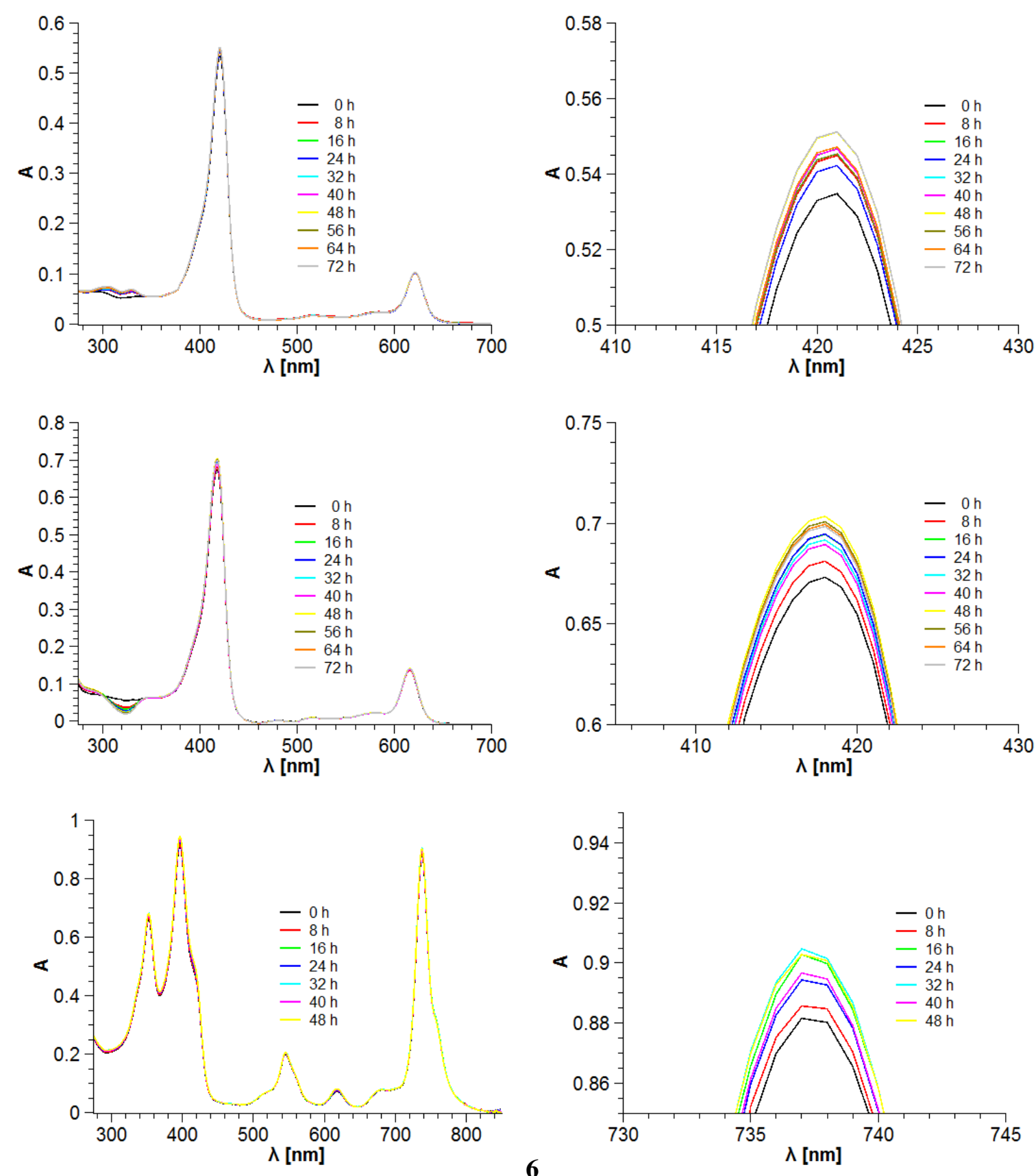

Fig. S25 UV-vis spectra of 10a (top), 10b (mid) and $\mathbf{1 1}$ (bottom) in acetonitrile at $37^{\circ} \mathrm{C}$ after irradiation with $505 \mathrm{~nm}$ for $5 \mathrm{~min}$. For a better overview only spectra in $8 \mathrm{~h}$ intervals are shown. 
The record players 10a, 10b and $\mathbf{1 1}$ showed only negligible changes in their absorption over 3 days. The paramagnetic Soret or Q bands did not decrease at all. No thermal cis-to-trans isomerisation could be observed even at $37^{\circ} \mathrm{C}$. The cis isomers are very stable over several weeks. The absorption partly increases because of concentration enhancement during the measurement (evaporation of the solvent acetonitrile at $37^{\circ} \mathrm{C}$ over several days).

Half-lifes of record player 12a and $\mathbf{1 2 b}$ were measured in water at $37^{\circ} \mathrm{C}$ (Fig. S26). Here, no cis-to-trans isomerization is observable. The absorption also increases slightly over time due to solvent evaporation.
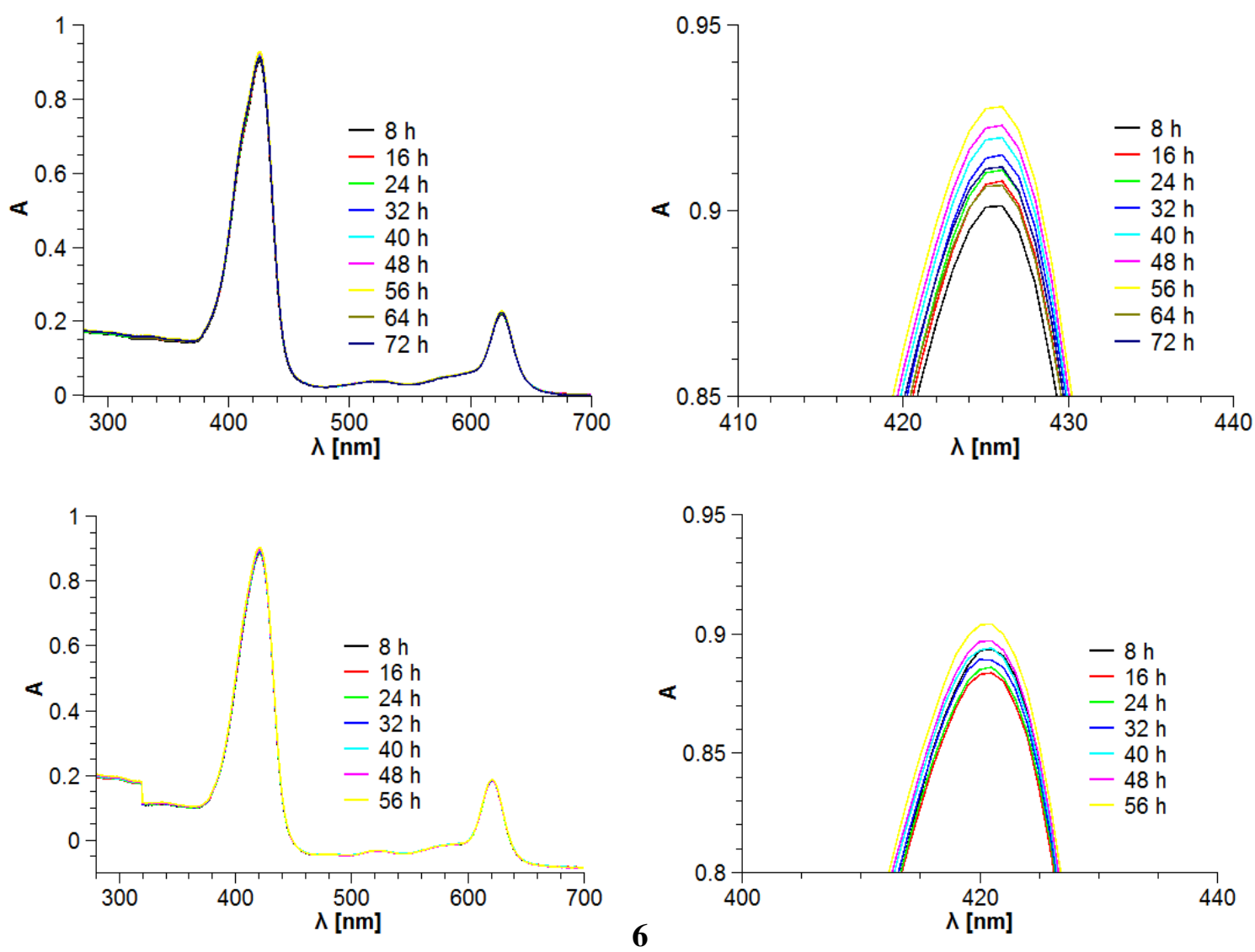

Fig. S26 UV-vis spectra of 12a (top), 12b (bottom) in water at $37^{\circ} \mathrm{C}$ after irradiation with $505 \mathrm{~nm}$ for $5 \mathrm{~min}$. For a better overview only spectra in $8 \mathrm{~h}$ intervals are shown. 


\section{Determination of Association Constants}

\section{III.1 Coordination of Pyridine}

The following equilibria were of interest (explained with the Ni(II) chlorin platform $2\left(\mathrm{Ni}-\mathrm{TPCF}_{20}\right)$ :

$$
\begin{aligned}
& {\left[\mathrm{Ni}-\mathrm{TPCF}_{20}\right]_{\mathrm{LS}}+[\mathrm{Py}] \stackrel{\kappa_{1 S}}{\longleftrightarrow}\left[\mathrm{Ni}-\mathrm{TPCF}_{20} \mathrm{Py}\right]_{\mathrm{HS}}} \\
& {\left[\mathrm{Ni}-\mathrm{TPCF}_{20} \mathrm{Py}\right]_{\mathrm{HS}}+[\mathrm{Py}] \stackrel{\kappa_{2}}{\longleftrightarrow}\left[\mathrm{Ni}-\mathrm{TPCF}_{20} \mathrm{Py}_{2}\right]_{\mathrm{HS}}} \\
& {\left[\mathrm{Ni}-\mathrm{TPCF}_{20}\right]_{\mathrm{LS}}+2[\mathrm{Py}] \stackrel{\beta}{\longleftrightarrow}\left[\mathrm{Ni}-\mathrm{TPCF}_{20} \mathrm{Py}_{2}\right]_{\mathrm{HS}}}
\end{aligned}
$$

with $[\mathrm{Py}]$

$\left[\mathrm{Ni}-\mathrm{TPCF}_{20}\right]_{\mathrm{LS}}$

$\left[\mathrm{Ni}-\mathrm{TPCF}_{20} \mathrm{Py}\right]_{\mathrm{HS}}$

$\left[\mathrm{Ni}-\mathrm{TPCF}_{20} \mathrm{Py}_{2}\right]_{\mathrm{HS}}$

LS

HS pyridine concentration

concentration of the square planar low spin chlorin comlex

concentration of the square pyramidal high spin chlorin complex

concentration of the octahedral high spin chlorin complex low spin

high spin

To investigate the coordination behavior of pyridine association constants of the non-borylated platform 2 were determined by ${ }^{1} \mathrm{H}$ NMR spectroscopy in toluene- $\mathrm{d}_{8}$. Overall, 20 NMR tubes were prepared with a Ni(II) platform concentration of $1.5 \mathrm{mM}$ (Table S1-S2). Upon addition of pyridine the signal of the pyrrole protons shifted downfield (Fig. S27-S28). The average chemical shift of these pyrrole proton signals was measured as a function of the pyridine concentration. Associations constants ( $\mathrm{K}_{1 \mathrm{~S}}$ and $\mathrm{K}_{2}$ ) were obtained from titrations curves using nonlinear fitting based on classical NewtonRaphson method with the excel add-in EST (Equilibrium Speciation Tool) (Table S3-S8, Fig. S29). ${ }^{10}$ The thermodynamic parameters were determined from temperature dependence of the association constants (Fig. S30, Table S9). The following solutions were used:

Ni-TPCF 20 2: The chlorin platform $2(22.08 \mathrm{mg}, 19.21 \mu \mathrm{mol})$ were solved in $8.152 \mathrm{~mL}$ toluene- $\mathrm{d}_{8}(\mathrm{c}=2.357 \mathrm{mM})$.

Pyridin- $\mathbf{d}_{6}$ toluene-d $\mathbf{d}_{\mathbf{8}}$ solution: $20.0 \mu \mathrm{L}$ pyridin- $\mathrm{d}_{6}$ were solved in $980 \mu \mathrm{L}$ toluene- $\mathrm{d}_{8}$. 
Table S1 Titration experiment with Ni-TPCF 20 (2).

\begin{tabular}{|c|c|c|c|c|c|}
\hline Sample & $\mathbf{V}_{\text {Ni-TPCF20 }}[\mu \mathrm{L}]$ & $\mathbf{V}_{\text {pyridin-toluene }}[\mu \mathrm{L}]$ & $\mathbf{V}_{\text {pyridin-d5 }}[\mu \mathrm{L}]$ & $\mathbf{V}_{\text {toluene-d8 }}[\mu \mathrm{L}]$ & $\mathbf{V}_{\text {total }}[\mu \mathrm{L}]$ \\
\hline 1 & 350 & 0.00 & - & 200 & 550 \\
\hline 2 & 350 & 6.00 & - & 194 & 550 \\
\hline 3 & 350 & 6.50 & - & 193.5 & 550 \\
\hline 4 & 350 & 7.50 & - & 192.5 & 550 \\
\hline 5 & 350 & 10.0 & - & 190 & 550 \\
\hline 6 & 350 & 11.5 & - & 188.5 & 550 \\
\hline 7 & 350 & 17.5 & - & 182.5 & 550 \\
\hline 8 & 350 & 25.0 & - & 175 & 550 \\
\hline 9 & 350 & 50.0 & - & 150 & 550 \\
\hline 10 & 350 & 100 & - & 100 & 550 \\
\hline 11 & 350 & - & 3.00 & 197 & 550 \\
\hline 12 & 350 & - & 4.00 & 196 & 550 \\
\hline 13 & 350 & - & 5.00 & 195 & 550 \\
\hline 14 & 350 & - & 7.00 & 193 & 550 \\
\hline 15 & 350 & - & 10.0 & 190 & 550 \\
\hline 16 & 350 & - & 15.0 & 185 & 550 \\
\hline 17 & 350 & - & 20.0 & 180 & 550 \\
\hline 18 & 350 & - & 30.0 & 170 & 550 \\
\hline 19 & 350 & - & 50.0 & 150 & 550 \\
\hline 20 & 350 & - & 75.0 & 125 & 550 \\
\hline
\end{tabular}

Table S2: Concentrations used in the ${ }^{1} \mathrm{H}$ NMR titration experiment with Ni-TPCF 20 (2).

\begin{tabular}{|c|c|c|c|}
\hline Sample & $\mathrm{C}_{\mathrm{Ni}-\mathrm{TPCF} 20}[\mathrm{mmol} / \mathrm{L}]$ & $\mathrm{C}_{\text {pyridin-d6 }}[\mathrm{mmol} / \mathrm{L}]$ & ratio $\mathrm{Ni}^{-\mathrm{TPCF}_{20}}$ /pyridin-d $_{6}$ \\
\hline 1 & 1.50 & 0.00 & 0.00 \\
\hline 2 & 1.50 & 2.70 & 1.80 \\
\hline 3 & 1.50 & 2.93 & 1.95 \\
\hline 4 & 1.50 & 3.38 & 2.25 \\
\hline 5 & 1.50 & 4.51 & 3.00 \\
\hline 6 & 1.50 & 5.18 & 3.45 \\
\hline 7 & 1.50 & 7.88 & 5.26 \\
\hline 8 & 1.50 & 11.26 & 7.51 \\
\hline 9 & 1.50 & 22.53 & 15.02 \\
\hline 10 & 1.50 & 45.05 & 30.03 \\
\hline 11 & 1.50 & 67.58 & 45.05 \\
\hline 12 & 1.50 & 90.10 & 60.06 \\
\hline 13 & 1.50 & 112.63 & 75.08 \\
\hline 14 & 1.50 & 157.68 & 105.11 \\
\hline 15 & 1.50 & 225.26 & 150.16 \\
\hline 16 & 1.50 & 337.89 & 225.24 \\
\hline 17 & 1.50 & 450.52 & 300.32 \\
\hline 18 & 1.50 & 675.78 & 450.48 \\
\hline 19 & 1.50 & 1126.31 & 750.80 \\
\hline 20 & 1.50 & 1689.46 & 1126.21 \\
\hline
\end{tabular}




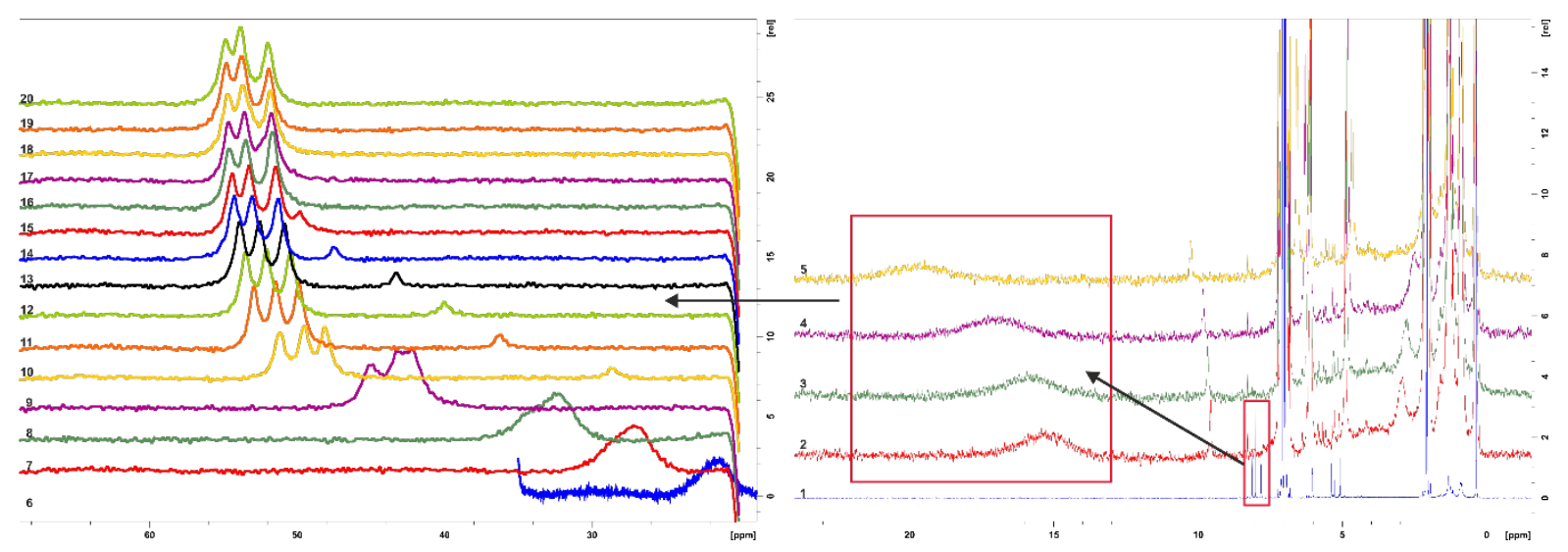

Fig. S27 Pyrrole proton shifts of compound 2 at different pyridine concentrations (samples 1-20) at $298 \mathrm{~K}$.

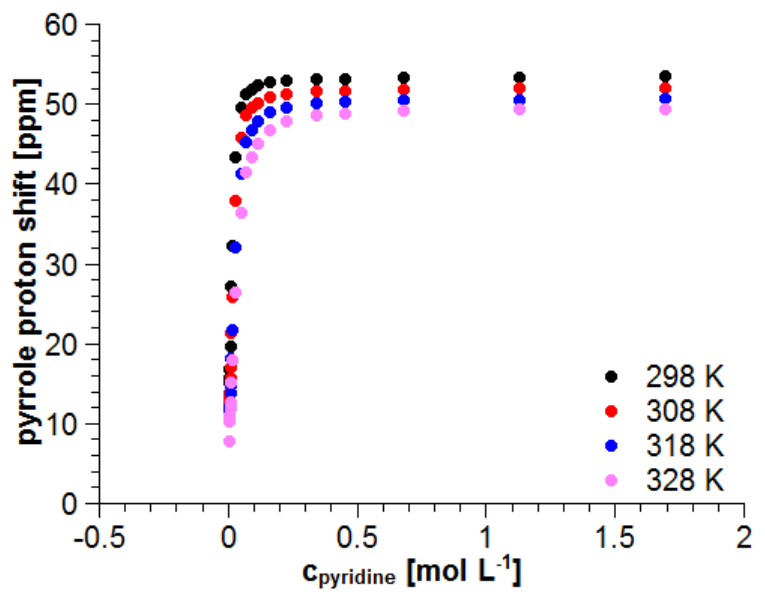

Fig. S28 ${ }^{1} \mathrm{H}$ NMR titration curves of Ni(II) chlorin platform 2 at different temperatures in toluene-d 8 . 
Table S3 Pyrrol proton shift of Ni(II) chlorin 2 at different temperatures and pyridine concentrations measured with ${ }^{1} \mathrm{H}$ NMR ( $\delta$ measured) or determined with excel EST ( $\delta$ EST). The mean square error (MSE) is between 0.493 and 1.790 .

\begin{tabular}{|c|c|c|c|c|c|c|c|c|}
\hline c pyridine & $\mid \begin{array}{c}\mathrm{T}=298 \mathrm{~K} \\
\delta \text { measured } \\
{[\mathrm{ppm}]}\end{array}$ & $\begin{array}{l}\delta \text { EST } \\
{[\mathrm{ppm}]}\end{array}$ & $\mid \begin{array}{c}\mathrm{T}=308 \mathrm{~K} \\
\delta \text { measured } \\
{[\mathrm{ppm}]}\end{array}$ & $\begin{array}{l}\delta \mathrm{EST} \\
{[\mathrm{ppm}]}\end{array}$ & $\begin{array}{c}\mathrm{T}=318 \mathrm{~K} \\
\delta \text { measured } \\
{[\mathrm{ppm}]}\end{array}$ & $\begin{array}{l}\delta \mathrm{EST} \\
{[\mathrm{ppm}]}\end{array}$ & $\mid \begin{array}{c}\mathrm{T}=328 \mathrm{~K} \\
\delta \text { measured } \\
{[\mathrm{ppm}]}\end{array}$ & $\begin{array}{l}\delta \text { EST } \\
{[\mathrm{ppm}]}\end{array}$ \\
\hline 0.0000 & 7.98 & 7.98 & 7.97 & 7.97 & 7.96 & 7.96 & 7.95 & 7.95 \\
\hline 0.0027 & 15.32 & 15.34 & 12.76 & 12.80 & 11.37 & 11.63 & 10.43 & 10.56 \\
\hline 0.0029 & 15.86 & 15.92 & 13.15 & 13.20 & 11.66 & 11.93 & 10.64 & 10.77 \\
\hline 0.0034 & 17.00 & 17.07 & 13.92 & 14.00 & 12.22 & 12.52 & 11.05 & 11.20 \\
\hline 0.0045 & 19.66 & 19.82 & 15.81 & 15.95 & 13.84 & 13.99 & 12.08 & 12.25 \\
\hline 0.0052 & 21.49 & 21.38 & 17.16 & 17.10 & 14.86 & 14.85 & 12.81 & 12.88 \\
\hline 0.0079 & 27.20 & 26.98 & 21.43 & 21.44 & 18.16 & 18.15 & 15.26 & 15.32 \\
\hline 0.0113 & 32.41 & 32.57 & 25.91 & 26.22 & 21.87 & 21.91 & 18.01 & 18.19 \\
\hline 0.0225 & 43.47 & 43.20 & 37.96 & 37.15 & 32.13 & 31.49 & 26.50 & 26.20 \\
\hline 0.0451 & 49.59 & 49.74 & 45.85 & 45.97 & 41.36 & 41.26 & 36.41 & 36.10 \\
\hline 0.0676 & 51.41 & 51.55 & 48.65 & 48.91 & 45.37 & 45.34 & 41.51 & 41.14 \\
\hline 0.0901 & 51.98 & 52.27 & 49.60 & 50.16 & 46.82 & 47.31 & 43.54 & 43.88 \\
\hline 0.1126 & 52.41 & 52.63 & 50.27 & 50.80 & 47.89 & 48.39 & 45.08 & 45.50 \\
\hline 0.1577 & 52.84 & 52.95 & 51.03 & 51.39 & 49.07 & 49.45 & 46.90 & 47.20 \\
\hline 0.2253 & 53.01 & 53.12 & 51.39 & 51.73 & 49.69 & 50.08 & 47.88 & 48.27 \\
\hline 0.3379 & 53.22 & 53.22 & 51.71 & 51.92 & 50.19 & 50.45 & 48.64 & 48.91 \\
\hline 0.4505 & 53.30 & 53.25 & 51.80 & 51.98 & 50.40 & 50.58 & 48.94 & 49.16 \\
\hline 0.6758 & 53.38 & 53.28 & 51.92 & 52.03 & 50.54 & 50.68 & 49.19 & 49.34 \\
\hline 1.1263 & 53.47 & 53.29 & 52.04 & 52.06 & 50.68 & 50.73 & 49.40 & 49.44 \\
\hline 1.6895 & 53.53 & 53.30 & 52.07 & 52.07 & 50.76 & 50.75 & 49.50 & 49.47 \\
\hline MSE & & 0.493 & & 1.790 & & 1.579 & & 1.13 \\
\hline
\end{tabular}

Table S4: Results of the titration experiment of $\mathrm{Ni}-\mathrm{TPCF}_{20} 2$ at $298 \mathrm{~K}$.

\begin{tabular}{|c|c|c|c|}
\hline $\begin{array}{c}\text { Cethyl isonicotinate } \\
\text { [mol/L] }\end{array}$ & $\begin{array}{c}\mathbf{C}_{\mathbf{1 0}} \\
{[\mathbf{m o l} / \mathbf{L}]}\end{array}$ & $\begin{array}{c}\mathbf{C}_{\mathbf{1 0} \cdot \mathbf{P} \mathbf{y}} \\
{[\mathbf{m o l} / \mathbf{L}]}\end{array}$ & $\begin{array}{c}\mathbf{C}_{\mathbf{1 0} \cdot \mathbf{2 P y}} \mathbf{2 P} \\
\mathbf{[ m o l} / \mathbf{L}]\end{array}$ \\
\hline 0 & $1.50 \mathrm{E}-03$ & 0 & 0 \\
\hline $2.42 \mathrm{E}-03$ & $1.26 \mathrm{E}-03$ & $2.08 \mathrm{E}-04$ & $3.59 \mathrm{E}-05$ \\
\hline $2.62 \mathrm{E}-03$ & $1.24 \mathrm{E}-03$ & $2.22 \mathrm{E}-04$ & $4.14 \mathrm{E}-05$ \\
\hline $3.02 \mathrm{E}-03$ & $1.20 \mathrm{E}-03$ & $2.47 \mathrm{E}-04$ & $5.34 \mathrm{E}-05$ \\
\hline $4.03 \mathrm{E}-03$ & $1.11 \mathrm{E}-03$ & $3.04 \mathrm{E}-04$ & $8.74 \mathrm{E}-05$ \\
\hline $4.63 \mathrm{E}-03$ & $1.06 \mathrm{E}-03$ & $3.34 \mathrm{E}-04$ & $1.10 \mathrm{E}-04$ \\
\hline $7.04 \mathrm{E}-03$ & $8.71 \mathrm{E}-04$ & $4.19 \mathrm{E}-04$ & $2.10 \mathrm{E}-04$ \\
\hline $1.01 \mathrm{E}-02$ & $6.86 \mathrm{E}-04$ & $4.73 \mathrm{E}-04$ & $3.41 \mathrm{E}-04$ \\
\hline $2.07 \mathrm{E}-02$ & $3.34 \mathrm{E}-04$ & $4.71 \mathrm{E}-04$ & $6.94 \mathrm{E}-04$ \\
\hline $4.26 \mathrm{E}-02$ & $1.18 \mathrm{E}-04$ & $3.42 \mathrm{E}-04$ & $1.04 \mathrm{E}-03$ \\
\hline $6.50 \mathrm{E}-02$ & $5.78 \mathrm{E}-05$ & $2.56 \mathrm{E}-04$ & $1.19 \mathrm{E}-03$ \\
\hline $8.74 \mathrm{E}-02$ & $3.40 \mathrm{E}-05$ & $2.03 \mathrm{E}-04$ & $1.26 \mathrm{E}-03$ \\
\hline $1.10 \mathrm{E}-01$ & $2.23 \mathrm{E}-05$ & $1.67 \mathrm{E}-04$ & $1.31 \mathrm{E}-03$ \\
\hline $1.55 \mathrm{E}-01$ & $1.17 \mathrm{E}-05$ & $1.24 \mathrm{E}-04$ & $1.36 \mathrm{E}-03$ \\
\hline $2.22 \mathrm{E}-01$ & $5.84 \mathrm{E}-06$ & $8.87 \mathrm{E}-05$ & $1.41 \mathrm{E}-03$ \\
\hline $3.35 \mathrm{E}-01$ & $2.63 \mathrm{E}-06$ & $6.02 \mathrm{E}-05$ & $1.44 \mathrm{E}-03$ \\
\hline $4.48 \mathrm{E}-01$ & $1.49 \mathrm{E}-06$ & $4.55 \mathrm{E}-05$ & $1.45 \mathrm{E}-03$ \\
\hline $6.73 \mathrm{E}-01$ & $6.67 \mathrm{E}-07$ & $3.06 \mathrm{E}-05$ & $1.47 \mathrm{E}-03$ \\
\hline $1.12 \mathrm{E}+00$ & $2.41 \mathrm{E}-07$ & $1.85 \mathrm{E}-05$ & $1.48 \mathrm{E}-03$ \\
\hline $1.69 \mathrm{E}+00$ & $1.08 \mathrm{E}-07$ & $1.24 \mathrm{E}-05$ & $1.49 \mathrm{E}-03$ \\
\hline
\end{tabular}


Table S5: Results of the titration experiment of $\mathrm{Ni}^{-\mathrm{TPCF}_{20}} 2$ at $308 \mathrm{~K}$.

\begin{tabular}{|c|c|c|c|}
\hline $\begin{array}{c}\text { Cethyl isonicotinate } \\
{[\mathbf{m o l} / \mathbf{L}]}\end{array}$ & $\begin{array}{c}\mathbf{C}_{\mathbf{1 0}} \\
{[\mathbf{m o l} / \mathbf{L}]}\end{array}$ & $\begin{array}{c}\mathbf{C}_{\mathbf{1 0} \cdot \mathbf{P y}} \\
{[\mathbf{m o l} / \mathbf{L}]}\end{array}$ & $\begin{array}{c}\mathbf{C}_{\mathbf{1 0} \cdot \mathbf{2 P y}} \\
{[\mathbf{m o l} / \mathbf{L}]}\end{array}$ \\
\hline 0 & $1.50 \mathrm{E}-03$ & 0 & 0 \\
\hline $2.42 \mathrm{E}-03$ & $1.34 \mathrm{E}-03$ & $1.44 \mathrm{E}-04$ & $2.03 \mathrm{E}-05$ \\
\hline $2.62 \mathrm{E}-03$ & $1.32 \mathrm{E}-03$ & $1.54 \mathrm{E}-04$ & $2.35 \mathrm{E}-05$ \\
\hline $3.02 \mathrm{E}-03$ & $1.30 \mathrm{E}-03$ & $1.74 \mathrm{E}-04$ & $3.06 \mathrm{E}-05$ \\
\hline $4.03 \mathrm{E}-03$ & $1.23 \mathrm{E}-03$ & $2.20 \mathrm{E}-04$ & $5.15 \mathrm{E}-05$ \\
\hline $4.63 \mathrm{E}-03$ & $1.19 \mathrm{E}-03$ & $2.45 \mathrm{E}-04$ & $6.58 \mathrm{E}-05$ \\
\hline $7.04 \mathrm{E}-03$ & $1.04 \mathrm{E}-03$ & $3.25 \mathrm{E}-04$ & $1.33 \mathrm{E}-04$ \\
\hline $1.01 \mathrm{E}-02$ & $8.79 \mathrm{E}-04$ & $3.92 \mathrm{E}-04$ & $2.28 \mathrm{E}-04$ \\
\hline $2.07 \mathrm{E}-02$ & $5.08 \mathrm{E}-04$ & $4.56 \mathrm{E}-04$ & $5.36 \mathrm{E}-04$ \\
\hline $4.26 \mathrm{E}-02$ & $2.07 \mathrm{E}-04$ & $3.81 \mathrm{E}-04$ & $9.12 \mathrm{E}-04$ \\
\hline $6.50 \mathrm{E}-02$ & $1.08 \mathrm{E}-04$ & $3.00 \mathrm{E}-04$ & $1.09 \mathrm{E}-03$ \\
\hline $8.74 \mathrm{E}-02$ & $6.50 \mathrm{E}-05$ & $2.44 \mathrm{E}-04$ & $1.19 \mathrm{E}-03$ \\
\hline $1.10 \mathrm{E}-01$ & $4.33 \mathrm{E}-05$ & $2.04 \mathrm{E}-04$ & $1.25 \mathrm{E}-03$ \\
\hline $1.55 \mathrm{E}-01$ & $2.30 \mathrm{E}-05$ & $1.53 \mathrm{E}-04$ & $1.32 \mathrm{E}-03$ \\
\hline $2.22 \mathrm{E}-01$ & $1.16 \mathrm{E}-05$ & $1.11 \mathrm{E}-04$ & $1.38 \mathrm{E}-03$ \\
\hline $3.35 \mathrm{E}-01$ & $5.28 \mathrm{E}-06$ & $7.57 \mathrm{E}-05$ & $1.42 \mathrm{E}-03$ \\
\hline $4.48 \mathrm{E}-01$ & $3.00 \mathrm{E}-06$ & $5.75 \mathrm{E}-05$ & $1.44 \mathrm{E}-03$ \\
\hline $6.73 \mathrm{E}-01$ & $1.35 \mathrm{E}-06$ & $3.88 \mathrm{E}-05$ & $1.46 \mathrm{E}-03$ \\
\hline $1.12 \mathrm{E}+00$ & $4.88 \mathrm{E}-07$ & $2.35 \mathrm{E}-05$ & $1.48 \mathrm{E}-03$ \\
\hline $1.69 \mathrm{E}+00$ & $2.18 \mathrm{E}-07$ & $1.57 \mathrm{E}-05$ & $1.48 \mathrm{E}-03$ \\
\hline & & &
\end{tabular}

Table S6: Results of the titration experiment of $\mathrm{Ni}^{-\mathrm{TPCF}_{20}} \mathbf{2}$ at $318 \mathrm{~K}$.

\begin{tabular}{|c|c|c|c|}
\hline $\begin{array}{c}\text { Cethyl isonicotinate } \\
{[\mathbf{m o l} / \mathbf{L}]}\end{array}$ & $\begin{array}{c}\mathbf{C}_{\mathbf{1 0}} \\
{[\mathbf{m o l} / \mathbf{L}]}\end{array}$ & $\begin{array}{c}\mathbf{C}_{\mathbf{1 0} \cdot \mathbf{P y}} \\
{[\mathbf{m o l} / \mathbf{L}]}\end{array}$ & $\begin{array}{c}\mathbf{C} \mathbf{1 0} \cdot \mathbf{2 P y} \\
{[\mathbf{m o l} / \mathbf{L}]}\end{array}$ \\
\hline 0 & $1.50 \mathrm{E}-03$ & 0 & 0 \\
\hline $2.42 \mathrm{E}-03$ & $1.37 \mathrm{E}-03$ & $1.19 \mathrm{E}-04$ & $9.89 \mathrm{E}-06$ \\
\hline $2.62 \mathrm{E}-03$ & $1.36 \mathrm{E}-03$ & $1.27 \mathrm{E}-04$ & $1.15 \mathrm{E}-05$ \\
\hline $3.02 \mathrm{E}-03$ & $1.34 \mathrm{E}-03$ & $1.45 \mathrm{E}-04$ & $1.51 \mathrm{E}-05$ \\
\hline $4.03 \mathrm{E}-03$ & $1.29 \mathrm{E}-03$ & $1.85 \mathrm{E}-04$ & $2.57 \mathrm{E}-05$ \\
\hline $4.63 \mathrm{E}-03$ & $1.26 \mathrm{E}-03$ & $2.08 \mathrm{E}-04$ & $3.32 \mathrm{E}-05$ \\
\hline $7.04 \mathrm{E}-03$ & $1.14 \mathrm{E}-03$ & $2.87 \mathrm{E}-04$ & $6.97 \mathrm{E}-05$ \\
\hline $1.01 \mathrm{E}-02$ & $1.01 \mathrm{E}-03$ & $3.63 \mathrm{E}-04$ & $1.26 \mathrm{E}-04$ \\
\hline $2.07 \mathrm{E}-02$ & $6.76 \mathrm{E}-04$ & $4.86 \mathrm{E}-04$ & $3.38 \mathrm{E}-04$ \\
\hline $4.26 \mathrm{E}-02$ & $3.33 \mathrm{E}-04$ & $4.85 \mathrm{E}-04$ & $6.82 \mathrm{E}-04$ \\
\hline $6.50 \mathrm{E}-02$ & $1.90 \mathrm{E}-04$ & $4.19 \mathrm{E}-04$ & $8.91 \mathrm{E}-04$ \\
\hline $8.74 \mathrm{E}-02$ & $1.21 \mathrm{E}-04$ & $3.58 \mathrm{E}-04$ & $1.02 \mathrm{E}-03$ \\
\hline $1.10 \mathrm{E}-01$ & $8.33 \mathrm{E}-05$ & $3.09 \mathrm{E}-04$ & $1.11 \mathrm{E}-03$ \\
\hline $1.55 \mathrm{E}-01$ & $4.61 \mathrm{E}-05$ & $2.41 \mathrm{E}-04$ & $1.21 \mathrm{E}-03$ \\
\hline $2.22 \mathrm{E}-01$ & $2.39 \mathrm{E}-05$ & $1.79 \mathrm{E}-04$ & $1.30 \mathrm{E}-03$ \\
\hline $3.35 \mathrm{E}-01$ & $1.11 \mathrm{E}-05$ & $1.25 \mathrm{E}-04$ & $1.36 \mathrm{E}-03$ \\
\hline $4.48 \mathrm{E}-01$ & $6.36 \mathrm{E}-06$ & $9.60 \mathrm{E}-05$ & $1.40 \mathrm{E}-03$ \\
\hline $6.73 \mathrm{E}-01$ & $2.88 \mathrm{E}-06$ & $6.54 \mathrm{E}-05$ & $1.43 \mathrm{E}-03$ \\
\hline $1.12 \mathrm{E}+00$ & $1.05 \mathrm{E}-06$ & $3.99 \mathrm{E}-05$ & $1.46 \mathrm{E}-03$ \\
\hline $1.69 \mathrm{E}+00$ & $4.72 \mathrm{E}-07$ & $2.68 \mathrm{E}-05$ & $1.47 \mathrm{E}-03$ \\
\hline & & &
\end{tabular}


Table S7: Results of the titration experiment of $\mathrm{Ni}^{-\mathrm{TPCF}_{20}} 2$ at $328 \mathrm{~K}$.

\begin{tabular}{|c|c|c|c|}
\hline $\begin{array}{c}\text { Cethyl isonicotinate } \\
{[\mathbf{m o l} / \mathbf{L}]}\end{array}$ & $\begin{array}{c}\mathbf{C}_{\mathbf{1 0}} \\
{[\mathbf{m o l} / \mathbf{L}]}\end{array}$ & $\begin{array}{c}\mathbf{C}_{\mathbf{1 0} \cdot \mathbf{P y}} \\
{[\mathbf{m o l} / \mathbf{L}]}\end{array}$ & $\begin{array}{c}\mathbf{C}_{\mathbf{1 0} \cdot \mathbf{2 P y}} \\
{[\mathbf{m o l} / \mathbf{L}]}\end{array}$ \\
\hline 0.00 & $1.50 \mathrm{E}-03$ & $0.00 \mathrm{E}+00$ & $0.00 \mathrm{E}+00$ \\
\hline $2.42 \mathrm{E}-03$ & $1.41 \mathrm{E}-03$ & $8.87 \mathrm{E}-05$ & $5.26 \mathrm{E}-06$ \\
\hline $2.62 \mathrm{E}-03$ & $1.40 \mathrm{E}-03$ & $9.56 \mathrm{E}-05$ & $6.14 \mathrm{E}-06$ \\
\hline $3.02 \mathrm{E}-03$ & $1.38 \mathrm{E}-03$ & $1.09 \mathrm{E}-04$ & $8.08 \mathrm{E}-06$ \\
\hline $4.03 \mathrm{E}-03$ & $1.34 \mathrm{E}-03$ & $1.41 \mathrm{E}-04$ & $1.39 \mathrm{E}-05$ \\
\hline $4.63 \mathrm{E}-03$ & $1.32 \mathrm{E}-03$ & $1.60 \mathrm{E}-04$ & $1.81 \mathrm{E}-05$ \\
\hline $7.04 \mathrm{E}-03$ & $1.23 \mathrm{E}-03$ & $2.27 \mathrm{E}-04$ & $3.91 \mathrm{E}-05$ \\
\hline $1.01 \mathrm{E}-02$ & $1.13 \mathrm{E}-03$ & $2.96 \mathrm{E}-04$ & $7.30 \mathrm{E}-05$ \\
\hline $2.07 \mathrm{E}-02$ & $8.41 \mathrm{E}-04$ & $4.41 \mathrm{E}-04$ & $2.17 \mathrm{E}-04$ \\
\hline $4.26 \mathrm{E}-02$ & $4.84 \mathrm{E}-04$ & $5.10 \mathrm{E}-04$ & $5.06 \mathrm{E}-04$ \\
\hline $6.50 \mathrm{E}-02$ & $3.02 \mathrm{E}-04$ & $4.80 \mathrm{E}-04$ & $7.18 \mathrm{E}-04$ \\
\hline $8.74 \mathrm{E}-02$ & $2.03 \mathrm{E}-04$ & $4.32 \mathrm{E}-04$ & $8.65 \mathrm{E}-04$ \\
\hline $1.10 \mathrm{E}-01$ & $1.44 \mathrm{E}-04$ & $3.86 \mathrm{E}-04$ & $9.69 \mathrm{E}-04$ \\
\hline $1.55 \mathrm{E}-01$ & $8.32 \mathrm{E}-05$ & $3.13 \mathrm{E}-04$ & $1.10 \mathrm{E}-03$ \\
\hline $2.22 \mathrm{E}-01$ & $4.45 \mathrm{E}-05$ & $2.40 \mathrm{E}-04$ & $1.22 \mathrm{E}-03$ \\
\hline $3.35 \mathrm{E}-01$ & $2.11 \mathrm{E}-05$ & $1.71 \mathrm{E}-04$ & $1.31 \mathrm{E}-03$ \\
\hline $4.48 \mathrm{E}-01$ & $1.23 \mathrm{E}-05$ & $1.33 \mathrm{E}-04$ & $1.35 \mathrm{E}-03$ \\
\hline $6.73 \mathrm{E}-01$ & $5.62 \mathrm{E}-06$ & $9.16 \mathrm{E}-05$ & $1.40 \mathrm{E}-03$ \\
\hline $1.12 \mathrm{E}+00$ & $2.07 \mathrm{E}-06$ & $5.64 \mathrm{E}-05$ & $1.44 \mathrm{E}-03$ \\
\hline $1.69 \mathrm{E}+00$ & $9.31 \mathrm{E}-07$ & $3.81 \mathrm{E}-05$ & $1.46 \mathrm{E}-03$ \\
\hline & & &
\end{tabular}
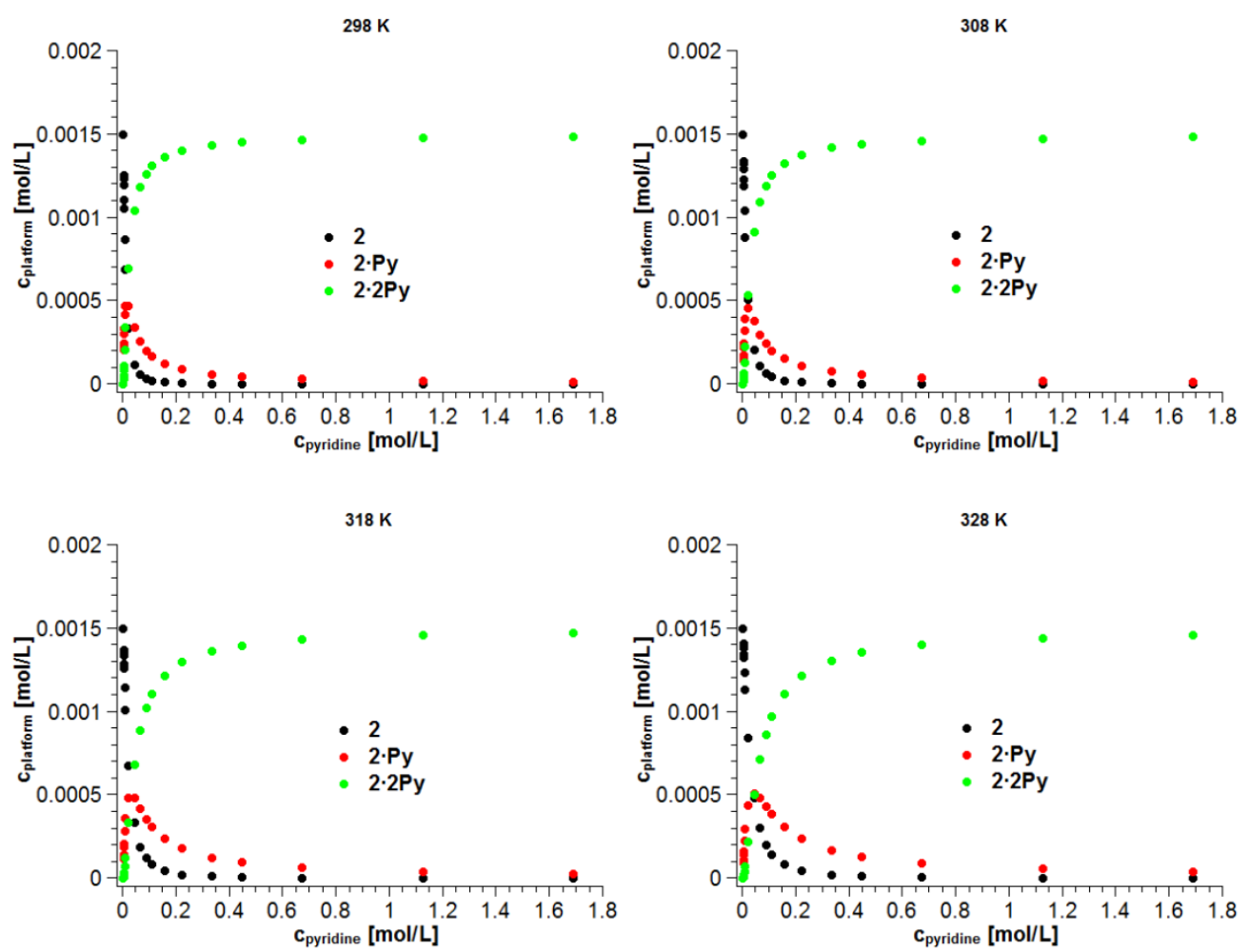

Fig. S29 Concentrations of the complexes 2, 2·Py and 2•2Py as a function of the added pyridine (Py) in the titration experiment in toluene- $\mathrm{d}_{8}$ at different temperatures. 
Table S8 Results for the association constants $\left(\mathrm{K}_{1 \mathrm{~S}}, \mathrm{~K}_{2}\right)$ of $\mathrm{Ni}(\mathrm{II})$ chlorin (2, Ni-TPCF $\left.\mathrm{T}_{20}\right)$ with pyridine at different temperatures.

\begin{tabular}{|c|c|c|c|c|c|}
\hline $\begin{array}{c}\mathbf{T} \\
{[\mathbf{K}]}\end{array}$ & $\begin{array}{c}\mathbf{T}^{-1} \\
{\left[\mathbf{K}^{-1}\right]}\end{array}$ & $\begin{array}{c}\mathrm{K}_{1 \mathrm{~S}} \\
{\left[\mathrm{~L} \mathrm{~mol}^{-1}\right]}\end{array}$ & $\begin{array}{c}\mathrm{K}_{2} \\
{\left[\mathrm{~L} \mathrm{~mol}^{-1}\right]}\end{array}$ & $\ln K_{1 S}$ & $\ln K_{2}$ \\
\hline 298 & 0.003355705 & 68.2 & 71.3 & 4.222445 & 4.266896 \\
\hline 308 & 0.003246753 & 42.8 & 55.9 & 3.756538 & 4.023564 \\
\hline 318 & 0.003144654 & 33.7 & 32.5 & 3.517498 & 3.481240 \\
\hline 328 & 0.00304878 & 24.2 & 22.8 & 3.186353 & 3.126761 \\
\hline
\end{tabular}

Due to temperature dependence of the association constants thermodynamic parameters like $\Delta \mathrm{H}$ and $\Delta \mathrm{S}$ can be determined with equation 1 .

$$
\Delta G=\Delta H-T \Delta S=-R T \cdot \ln K
$$

Solving equation 1 to $\ln \mathrm{K}$ gives the linear equation 2.

$$
\ln K=-\frac{\Delta H}{R} \cdot \frac{1}{T}+\frac{\Delta S}{R}
$$

with the slobe $-\frac{\Delta H}{R}$ and y-intercept $\frac{\Delta S}{R}$.

The plots $\ln \mathrm{K}$ against 1/T are shown in Fig. S30. All values are summarized in table 9.
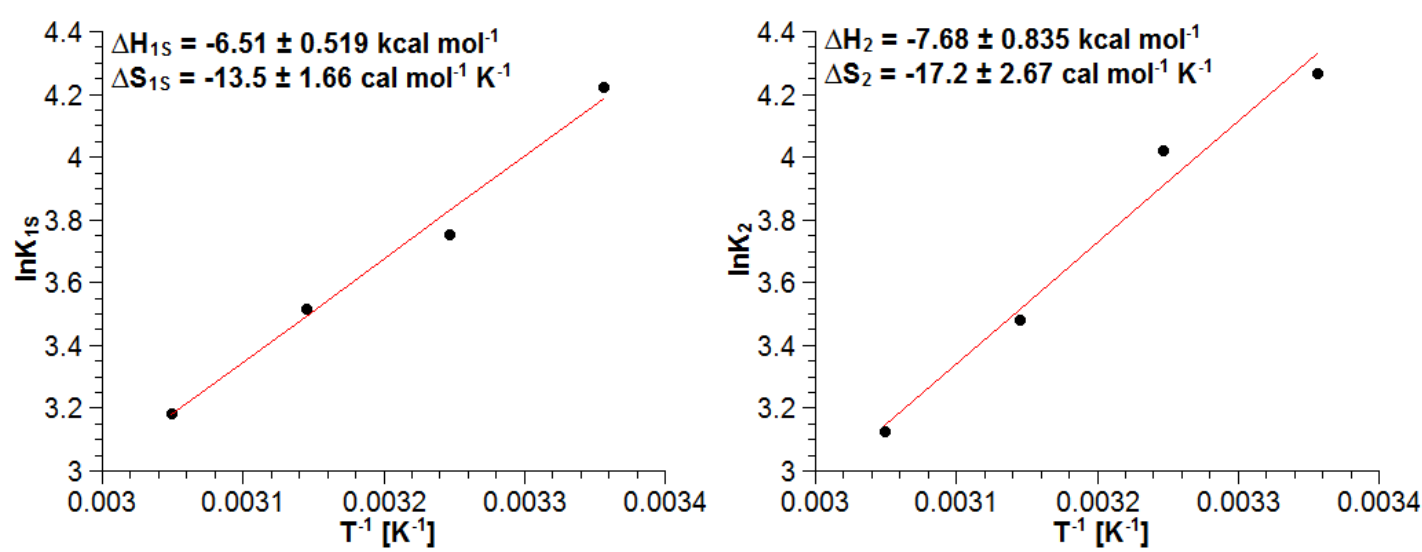

Fig. S30 Plots of $\ln K_{1 S}$ (left) and $\ln K_{2}$ (right) against $1 / T$ for determination of the thermodynamic parameters $\Delta \mathrm{H}$ and $\Delta \mathrm{S}$ for $\mathrm{Ni}(\mathrm{II})$ chlorin 2 . 
Table S9 Determined association constants ( $\mathrm{K}_{1 \mathrm{~s}}, \mathrm{~K}_{2}$ and $\mathrm{K}_{\beta}$ with $\beta=\mathrm{K}_{1 \mathrm{~s}} \cdot \mathrm{K}_{2}$ ) of the coordination of pyridine with EST and thermodynamic parameters of the platforms $\mathbf{1}$ and $\mathbf{2}$.

\begin{tabular}{|c|c|c|c|c|c|}
\hline & $\mathrm{Ni}-\mathbf{T P P F}_{20}{ }^{11}$ & \multicolumn{4}{|c|}{$\mathrm{Ni}-\mathrm{TPCF}_{20}$} \\
\hline temperature [K] & $300^{11}$ & 298 & 308 & 318 & 328 \\
\hline $\mathrm{K}_{1 \mathrm{SS}}\left[\mathbf{L} \cdot \mathbf{m o l}^{-1}\right]$ & 7.8 & 68.2 & 42.8 & 33.7 & 24.2 \\
\hline $\mathbf{K}_{2}\left[\mathbf{L} \cdot \mathbf{m o l}^{-1}\right]$ & 20.5 & 71.3 & 55.9 & 32.5 & 22.8 \\
\hline$\beta\left[\mathbf{L}^{2} \cdot \mathbf{m o l}^{-2}\right]$ & 159.9 & 4863.2 & 2395.4 & 1096.4 & 551.6 \\
\hline$\Delta \mathbf{H}_{1 \mathrm{~s}}\left[\mathrm{kcal} \cdot \mathrm{mol}^{-1}{ }^{-1}\right]$ & -5.3 & \multicolumn{4}{|c|}{$-6.51 \pm 0.519$} \\
\hline 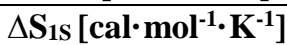 & -13.6 & \multirow{2}{*}{\multicolumn{4}{|c|}{$-13.5 \pm 1.66$}} \\
\hline$\Delta \mathbf{H}_{2}\left[\mathrm{kcal} \cdot \mathrm{mol}^{-1}\right]$ & -6.0 & \multirow{2}{*}{\multicolumn{4}{|c|}{$\frac{-7.68 \pm 0.835}{-172+2.67}$}} \\
\hline$\Delta \mathbf{S}_{2}\left[\mathrm{cal}^{\cdot} \mathbf{m o l}^{-1} \cdot \mathbf{K}^{-1}\right]$ & -13.9 & & & & \\
\hline
\end{tabular}

Unfortunately, the association constants of the coordination of pyridine to bacteriochlorin $\mathbf{3}$ could not be determined with ${ }^{1} \mathrm{H}$ NMR or UV-vis spectroscopy, because the coordination of pyridine ( $\mathrm{pk}_{\mathrm{b}}=8.75$ at $25^{\circ} \mathrm{C}$ ) was too strong. Therefore, the titration experiment was repeated with the weaker ligand ethyl isonicotinate $\left(\mathrm{pk}_{\mathrm{b}}=10.55\right.$ at $\left.25^{\circ} \mathrm{C}\right)$.

\section{III.2 Coordination of Ethyl Isonicotinate}

Due to an insufficient solubility of bacteriochlorin 3 in toluene UV-vis spectroscopy was chosen as detection method instead of ${ }^{1} \mathrm{H}$ NMR spectroscopy. For better comparability UV-vis titration experiments with the ligand ethyl isonicotinate (EtOOC-Py) were done with $\mathrm{Ni}^{-\mathrm{TPCF}_{20}} 2$ and $\mathrm{Ni}-\mathrm{TPBF}_{20} 3$.

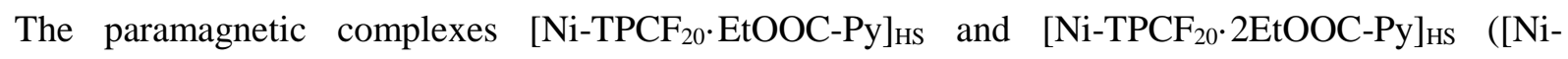
$\mathrm{TPBF}_{20} \cdot$ EtOOC-Py $_{\mathrm{HS}}$ and $\left[\mathrm{Ni}-\mathrm{TPCF}_{20} \cdot 2 \mathrm{EtOOC}-\mathrm{Py}\right]_{\mathrm{Hs}}$ respectively) cannot be observed separately. Assuming their absorption wavelengths and extinction coefficients are almost equal, the overall concentration of the paramagnetic $\mathrm{Ni}(\mathrm{II})$ complexes and the diamagnetic $\mathrm{Ni}(\mathrm{II})$ complex $\left(\mathrm{Ni}-\mathrm{TPCF}_{20}\right.$ or $\mathrm{Ni}-\mathrm{TPBF}_{20}$ ) can be estimated from the decreasing absorption at a specific wavelength ( $409 \mathrm{~nm}$ for platform 2 and $762 \mathrm{~nm}$ for platform 3) by non-linear fitting with the excel add-in EST (Equilibrium Speciation Tool). ${ }^{10}$

The cuvette $(\mathrm{d}=1 \mathrm{~cm})$ was filled with $2500 \mu \mathrm{L}$ of a prepared parent solution of Ni-TPCF 20 or Ni$\mathrm{TPBF}_{20}$ 3. In small steps ethyl isonicotinate was added. Fig. S31 shows the UV titration curves of 
compound 2 and 3 at $293 \mathrm{~K}$. The used concentrations and ligand/platform ratios are given in tables S10 and S11.
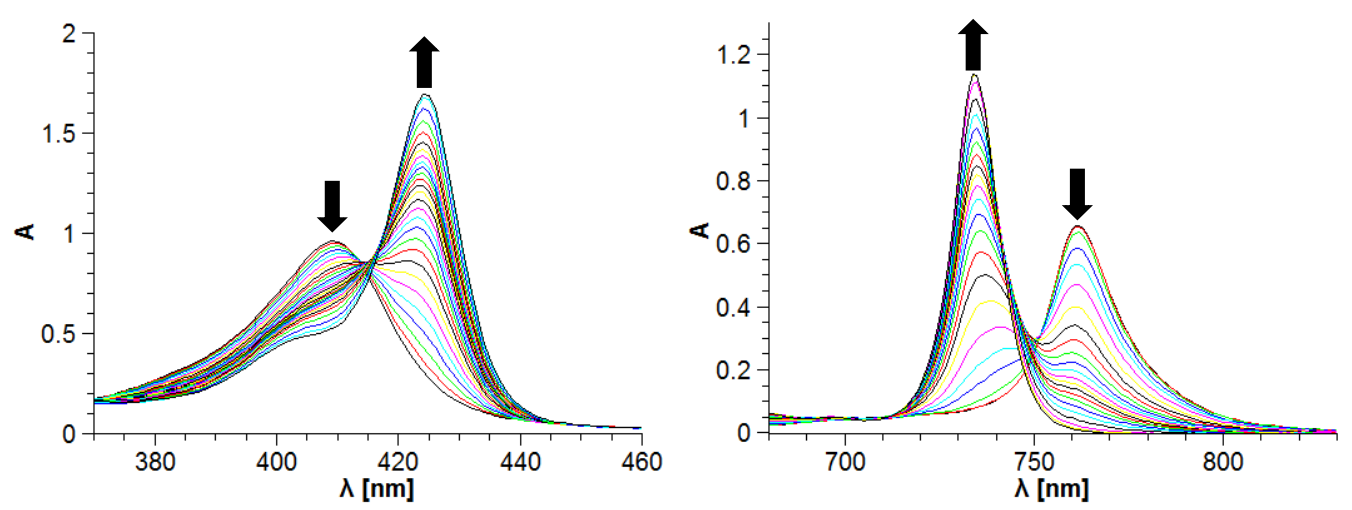

Fig. S31 UV-vis titration experiment of Ni-TPCF 202 (left) and Ni-TPBF 203 (right) at $293 \mathrm{~K}$. For chlorin 2 the band at $409 \mathrm{~nm}$ and for the bacteriochlorin 3 the band at $762 \mathrm{~nm}$ decreases, while the other band increases.

Table S10 Concentrations used in the UV-vis titration experiment with Ni-TPCF 202.

\begin{tabular}{|c|c|c|c|}
\hline Sample & $\mathrm{C}_{\mathrm{Ni}-\mathrm{TPCF} 20}[\mathrm{~mol} / \mathrm{L}]$ & $\mathrm{C}_{\text {ethyl isonicotinate }}[\mathrm{mol} / \mathrm{L}]$ & ratio $\mathrm{Ni}-\mathrm{TPCF}_{20} / \mathrm{ethyl}$ isonicotinate \\
\hline 1 & $8.021 \mathrm{E}-06$ & $0.000 \mathrm{E}+00$ & 0.00 \\
\hline 2 & $8.018 \mathrm{E}-06$ & 1.333E-03 & 166.27 \\
\hline 3 & 8.015E-06 & $2.665 \mathrm{E}-03$ & 332.53 \\
\hline 4 & $8.011 \mathrm{E}-06$ & 3.996E-03 & 498.80 \\
\hline 5 & $8.008 \mathrm{E}-06$ & $5.326 \mathrm{E}-03$ & 665.06 \\
\hline 6 & $8.005 E-06$ & $6.655 \mathrm{E}-03$ & 831.33 \\
\hline 7 & $8.002 \mathrm{E}-06$ & 7.982E-03 & 997.59 \\
\hline 8 & 7.999E-06 & $9.309 \mathrm{E}-03$ & 1163.86 \\
\hline 9 & 7.995E-06 & 1.063E-02 & 1330.12 \\
\hline 10 & 7.992E-06 & $1.196 \mathrm{E}-02$ & 1496.39 \\
\hline 11 & 7.989E-06 & $1.328 \mathrm{E}-02$ & 1662.65 \\
\hline 12 & 7.986E-06 & $1.461 \mathrm{E}-02$ & 1828.92 \\
\hline 13 & 7.983E-06 & 1.593E-02 & 1995.18 \\
\hline 14 & 7.979E-06 & 1.725E-02 & 2161.45 \\
\hline 15 & 7.976E-06 & 1.857E-02 & 2327.71 \\
\hline 16 & 7.973E-06 & $1.988 \mathrm{E}-02$ & 2493.98 \\
\hline 17 & 7.970E-06 & $2.120 \mathrm{E}-02$ & 2660.24 \\
\hline 18 & 7.967E-06 & $2.252 \mathrm{E}-02$ & 2826.51 \\
\hline 19 & 7.964E-06 & 2.383E-02 & 2992.77 \\
\hline 20 & $7.960 \mathrm{E}-06$ & $2.515 \mathrm{E}-02$ & 3159.04 \\
\hline 21 & 7.954E-06 & $2.777 \mathrm{E}-02$ & 3491.57 \\
\hline 22 & 7.948E-06 & 3.039E-02 & 3824.10 \\
\hline 23 & 7.938E-06 & 3.432E-02 & 4322.89 \\
\hline 24 & 7.923E-06 & 4.084E-02 & 5154.22 \\
\hline 25 & 7.891E-06 & $5.380 \mathrm{E}-02$ & 6816.87 \\
\hline 26 & 7.830E-06 & 7.941E-02 & 10142.17 \\
\hline 27 & 7.769E-06 & $1.305 \mathrm{E}-01$ & 16792.77 \\
\hline 28 & 7.680E-06 & $2.056 \mathrm{E}-01$ & 26768.67 \\
\hline 29 & 7.564E-06 & 3.031E-01 & 40069.88 \\
\hline
\end{tabular}


Table S11 Concentrations used in the UV-vis titration experiment with $\mathrm{Ni}^{-\mathrm{TPBF}_{20} 3 .}$

\begin{tabular}{|c|c|c|c|}
\hline Sample & $\mathrm{C}_{\mathrm{Ni}-\mathrm{TPBF} 20}[\mathrm{~mol} / \mathrm{L}]$ & Cethyl isonicotinate $[\mathrm{mol} / \mathrm{L}]$ & ratio $\mathrm{Ni}^{-\mathrm{TPBF}_{20} / \text { ethyl isonicotinate }}$ \\
\hline 1 & $8.013 E-06$ & $0.000 \mathrm{E}+00$ & 0.00 \\
\hline 2 & 7.997E-06 & $2.218 \mathrm{E}-05$ & 2.77 \\
\hline 3 & 7.981E-06 & $2.878 \mathrm{E}-04$ & 36.06 \\
\hline 4 & $7.978 \mathrm{E}-06$ & $8.188 \mathrm{E}-04$ & 102.64 \\
\hline 5 & $7.974 \mathrm{E}-06$ & 1.349E-03 & 169.21 \\
\hline 6 & 7.970E-06 & $2.144 \mathrm{E}-03$ & 269.07 \\
\hline 7 & 7.963E-06 & 3.203E-03 & 402.22 \\
\hline 8 & 7.957E-06 & $4.260 \mathrm{E}-03$ & 535.37 \\
\hline 9 & 7.951E-06 & 5.315E-03 & 668.52 \\
\hline 10 & 7.944E-06 & 6.369E-03 & 801.67 \\
\hline 11 & 7.938E-06 & $7.421 \mathrm{E}-03$ & 934.82 \\
\hline 12 & $7.932 \mathrm{E}-06$ & $8.471 \mathrm{E}-03$ & 1067.97 \\
\hline 13 & $7.925 E-06$ & 9.519E-03 & 1201.12 \\
\hline 14 & 7.919E-06 & 1.057E-02 & 1334.27 \\
\hline 15 & 7.913E-06 & 1.161E-02 & 1467.42 \\
\hline 16 & 7.904E-06 & $1.318 \mathrm{E}-02$ & 1667.14 \\
\hline 17 & $7.891 \mathrm{E}-06$ & $1.526 \mathrm{E}-02$ & 1933.44 \\
\hline 18 & 7.872E-06 & 1.837E-02 & 2332.89 \\
\hline 19 & 7.842E-06 & $2.351 \mathrm{E}-02$ & 2998.64 \\
\hline 20 & 7.781E-06 & 3.369E-02 & 4330.14 \\
\hline 21 & 7.751E-06 & 5.936E-02 & 7658.88 \\
\hline 22 & 7.691E-06 & $1.101 \mathrm{E}-01$ & 14316.35 \\
\hline 23 & $7.575 E-06$ & 2.093E-01 & 27631.31 \\
\hline
\end{tabular}

The results of the titration experiments at different temperatures are shown in tables S12-S17 and Fig. S32 and S33.

Table S12 Results of the titration experiment of Ni-TPCF 202 at $293 \mathrm{~K}$.

\begin{tabular}{|c|c|c|c|c|}
\hline $\begin{array}{c}\text { Cethyl isonicotinate } \\
{[\mathbf{m o l} / \mathbf{L}]}\end{array}$ & $\mathbf{A} @ \mathbf{9} \mathbf{4 0 9} \mathbf{~ n m}$ & $\begin{array}{c}\mathbf{C}_{\mathbf{1 0}} \\
{[\mathbf{m o l} / \mathbf{L}]}\end{array}$ & $\begin{array}{c}\mathbf{C}_{\mathbf{1 0} \cdot \mathbf{E t O o c}-P \mathbf{y}} \\
{[\mathbf{m o l} / \mathbf{L}]}\end{array}$ & $\begin{array}{c}\mathbf{C}_{\mathbf{1 0} \cdot \mathbf{2 E t O O C}-\mathbf{P y}} \\
{[\mathbf{m o l} / \mathbf{L}]}\end{array}$ \\
\hline 0 & 0.95897 & $8.02 \mathrm{e}-06$ & 0 & 0 \\
\hline 0.00133 & 0.946833 & $7.64 \mathrm{e}-06$ & $3.67 \mathrm{e}-07$ & $1.52 \mathrm{e}-08$ \\
\hline 0.00266 & 0.929824 & $7.26 \mathrm{e}-06$ & $6.98 \mathrm{e}-07$ & $5.77 \mathrm{e}-08$ \\
\hline 0.00399 & 0.910153 & $6.89 \mathrm{e}-06$ & $9.94 \mathrm{e}-07$ & $1.23 \mathrm{e}-07$ \\
\hline 0.00532 & 0.889791 & $6.54 \mathrm{e}-06$ & $1.26 \mathrm{e}-06$ & $2.08 \mathrm{e}-07$ \\
\hline 0.00665 & 0.867575 & $6.21 \mathrm{e}-06$ & $1.49 \mathrm{e}-06$ & $3.07 \mathrm{e}-07$ \\
\hline 0.00798 & 0.845997 & $5.89 \mathrm{e}-06$ & $1.70 \mathrm{e}-06$ & $4.20 \mathrm{e}-07$ \\
\hline 0.00931 & 0.825569 & $5.58 \mathrm{e}-06$ & $1.87 \mathrm{e}-06$ & $5.41 \mathrm{e}-07$ \\
\hline 0.0106 & 0.807171 & $5.29 \mathrm{e}-06$ & $2.03 \mathrm{e}-06$ & $6.70 \mathrm{e}-07$ \\
\hline 0.012 & 0.789231 & $5.02 \mathrm{e}-06$ & $2.17 \mathrm{e}-06$ & $8.03 \mathrm{e}-07$ \\
\hline 0.0133 & 0.772844 & $4.77 \mathrm{e}-06$ & $2.28 \mathrm{e}-06$ & $9.40 \mathrm{e}-07$ \\
\hline 0.0146 & 0.758148 & $4.52 \mathrm{e}-06$ & $2.38 \mathrm{e}-06$ & $1.08 \mathrm{e}-06$ \\
\hline 0.0159 & 0.744622 & $4.30 \mathrm{e}-06$ & $2.47 \mathrm{e}-06$ & $1.22 \mathrm{e}-06$ \\
\hline 0.0172 & 0.731832 & $4.08 \mathrm{e}-06$ & $2.54 \mathrm{e}-06$ & $1.36 \mathrm{e}-06$ \\
\hline 0.0186 & 0.719743 & $3.88 \mathrm{e}-06$ & $2.60 \mathrm{e}-06$ & $1.50 \mathrm{e}-06$ \\
\hline 0.0199 & 0.709394 & $3.69 \mathrm{e}-06$ & $2.65 \mathrm{e}-06$ & $1.63 \mathrm{e}-06$ \\
\hline 0.0212 & 0.69971 & $3.51 \mathrm{e}-06$ & $2.69 \mathrm{e}-06$ & $1.77 \mathrm{e}-06$ \\
\hline 0.0225 & 0.692038 & $3.35 \mathrm{e}-06$ & $2.72 \mathrm{e}-06$ & $1.90 \mathrm{e}-06$ \\
\hline 0.0238 & 0.683718 & $3.19 \mathrm{e}-06$ & $2.74 \mathrm{e}-06$ & $2.03 \mathrm{e}-06$ \\
\hline 0.0251 & 0.675444 & $3.04 \mathrm{e}-06$ & $2.76 \mathrm{e}-06$ & $2.15 \mathrm{e}-06$ \\
\hline 0.0278 & 0.664112 & $2.78 \mathrm{e}-06$ & $2.78 \mathrm{e}-06$ & $2.40 \mathrm{e}-06$ \\
\hline 0.0304 & 0.653883 & $2.54 \mathrm{e}-06$ & $2.78 \mathrm{e}-06$ & $2.62 \mathrm{e}-06$ \\
\hline 0.0343 & 0.641239 & $2.23 \mathrm{e}-06$ & $2.76 \mathrm{e}-06$ & $2.94 \mathrm{e}-06$ \\
\hline & & & &
\end{tabular}


Table S13 Results of the titration experiment of Ni-TPCF 20 at $298 \mathrm{~K}$.

\begin{tabular}{|c|c|c|c|c|}
\hline $\begin{array}{c}\text { Cethyl isonicotinate } \\
{[\mathbf{m o l} / \mathbf{L}]}\end{array}$ & $\mathbf{A} @ \mathbf{~} \mathbf{4 0 9} \mathbf{~ n m}$ & $\begin{array}{c}\mathbf{C}_{\mathbf{1 0}} \\
{[\mathbf{m o l} / \mathbf{L}]}\end{array}$ & $\begin{array}{c}\mathbf{C}_{\mathbf{1 0} \cdot \mathbf{E t O O C}-P \mathbf{y}} \\
{[\mathbf{m o l} / \mathbf{L}]}\end{array}$ & $\begin{array}{c}\mathbf{C}_{\mathbf{1 0} \cdot \mathbf{2 E t O O C}-\mathbf{P y}} \\
{[\mathbf{m o l} / \mathbf{L}]}\end{array}$ \\
\hline 0 & 0.309534 & $8.02 \mathrm{e}-06$ & 0 & 0 \\
\hline 0.00133 & 0.349818 & $7.72 \mathrm{e}-06$ & $2.83 \mathrm{e}-07$ & $1.23 \mathrm{e}-08$ \\
\hline 0.00266 & 0.402265 & $7.42 \mathrm{e}-06$ & $5.44 \mathrm{e}-07$ & $4.72 \mathrm{e}-08$ \\
\hline 0.00399 & 0.461836 & $7.13 \mathrm{e}-06$ & $7.83 \mathrm{e}-07$ & $1.02 \mathrm{e}-07$ \\
\hline 0.00532 & 0.525096 & $6.83 \mathrm{e}-06$ & $1.00 \mathrm{e}-06$ & $1.74 \mathrm{e}-07$ \\
\hline 0.00665 & 0.595266 & $6.55 \mathrm{e}-06$ & $1.20 \mathrm{e}-06$ & $2.60 \mathrm{e}-07$ \\
\hline 0.00798 & 0.660364 & $6.27 \mathrm{e}-06$ & $1.38 \mathrm{e}-06$ & $3.58 \mathrm{e}-07$ \\
\hline 0.00931 & 0.725383 & $6.00 \mathrm{e}-06$ & $1.53 \mathrm{e}-06$ & $4.66 \mathrm{e}-07$ \\
\hline 0.0106 & 0.789844 & $5.74 \mathrm{e}-06$ & $1.68 \mathrm{e}-06$ & $5.81 \mathrm{e}-07$ \\
\hline 0.012 & 0.847424 & $5.49 \mathrm{e}-06$ & $1.80 \mathrm{e}-06$ & $7.03 \mathrm{e}-07$ \\
\hline 0.0133 & 0.906413 & $5.25 \mathrm{e}-06$ & $1.91 \mathrm{e}-06$ & $8.29 \mathrm{e}-07$ \\
\hline 0.0146 & 0.958515 & $5.01 \mathrm{e}-06$ & $2.01 \mathrm{e}-06$ & $9.58 \mathrm{e}-07$ \\
\hline 0.0159 & 1.007048 & $4.79 \mathrm{e}-06$ & $2.10 \mathrm{e}-06$ & $1.09 \mathrm{e}-06$ \\
\hline 0.0172 & 1.053231 & $4.58 \mathrm{e}-06$ & $2.17 \mathrm{e}-06$ & $1.22 \mathrm{e}-06$ \\
\hline 0.0186 & 1.095808 & $4.39 \mathrm{e}-06$ & $2.24 \mathrm{e}-06$ & $1.35 \mathrm{e}-06$ \\
\hline 0.0199 & 1.130586 & $4.20 \mathrm{e}-06$ & $2.29 \mathrm{e}-06$ & $1.49 \mathrm{e}-06$ \\
\hline 0.0212 & 1.167348 & $4.01 \mathrm{e}-06$ & $2.34 \mathrm{e}-06$ & $1.62 \mathrm{e}-06$ \\
\hline 0.0225 & 1.19871 & $3.84 \mathrm{e}-06$ & $2.38 \mathrm{e}-06$ & $1.75 \mathrm{e}-06$ \\
\hline 0.0238 & 1.226325 & $3.68 \mathrm{e}-06$ & $2.41 \mathrm{e}-06$ & $1.87 \mathrm{e}-06$ \\
\hline 0.0251 & 1.254066 & $3.53 \mathrm{e}-06$ & $2.44 \mathrm{e}-06$ & $2.00 \mathrm{e}-06$ \\
\hline 0.0278 & 1.304811 & $3.24 \mathrm{e}-06$ & $2.47 \mathrm{e}-06$ & $2.24 \mathrm{e}-06$ \\
\hline 0.0304 & 1.337855 & $2.98 \mathrm{e}-06$ & $2.49 \mathrm{e}-06$ & $2.47 \mathrm{e}-06$ \\
\hline 0.0343 & 1.359573 & $2.65 \mathrm{e}-06$ & $2.50 \mathrm{e}-06$ & $2.79 \mathrm{e}-06$ \\
\hline & & & & \\
\hline & & & & \\
\hline
\end{tabular}

Table S14 Results of the titration experiment of Ni-TPCF 202 at $303 \mathrm{~K}$.

\begin{tabular}{|c|c|c|c|c|}
\hline $\begin{array}{c}\text { Cethyl isonicotinate } \\
{[\mathbf{m o l} / \mathbf{L}]}\end{array}$ & $\mathbf{A}$ @ 409 nm & $\begin{array}{c}\mathbf{C}_{\mathbf{1 0}} \\
{[\mathbf{m o l} / \mathbf{L}]}\end{array}$ & $\begin{array}{c}\mathbf{C}_{\mathbf{1 0} \cdot \mathbf{E t O o c}-\mathbf{P y}} \\
{[\mathbf{m o l} / \mathbf{L}]}\end{array}$ & $\begin{array}{c}\mathbf{C}_{\mathbf{1 0} \cdot \mathbf{2 E t O O C}-\mathbf{P y}} \\
{[\mathbf{m o l} / \mathbf{L}]}\end{array}$ \\
\hline 0 & 0.962339 & $8.02 \mathrm{e}-06$ & 0 & 0 \\
\hline 0.00133 & 0.959448 & $7.79 \mathrm{e}-06$ & $2.20 \mathrm{e}-07$ & $8.38 \mathrm{e}-09$ \\
\hline 0.00266 & 0.955272 & $7.56 \mathrm{e}-06$ & $4.26 \mathrm{e}-07$ & $3.25 \mathrm{e}-08$ \\
\hline 0.00399 & 0.935371 & $7.32 \mathrm{e}-06$ & $6.18 \mathrm{e}-07$ & $7.08 \mathrm{e}-08$ \\
\hline 0.00532 & 0.922975 & $7.09 \mathrm{e}-06$ & $7.98 \mathrm{e}-07$ & $1.22 \mathrm{e}-07$ \\
\hline 0.00665 & 0.907772 & $6.86 \mathrm{e}-06$ & $9.64 \mathrm{e}-07$ & $1.84 \mathrm{e}-07$ \\
\hline 0.00798 & 0.899545 & $6.63 \mathrm{e}-06$ & $1.12 \mathrm{e}-06$ & $2.56 \mathrm{e}-07$ \\
\hline 0.00931 & 0.880487 & $6.40 \mathrm{e}-06$ & $1.26 \mathrm{e}-06$ & $3.36 \mathrm{e}-07$ \\
\hline 0.0106 & 0.862882 & $6.18 \mathrm{e}-06$ & $1.39 \mathrm{e}-06$ & $4.23 \mathrm{e}-07$ \\
\hline 0.012 & 0.851655 & $5.97 \mathrm{e}-06$ & $1.51 \mathrm{e}-06$ & $5.17 \mathrm{e}-07$ \\
\hline 0.0133 & 0.836861 & $5.76 \mathrm{e}-06$ & $1.62 \mathrm{e}-06$ & $6.15 \mathrm{e}-07$ \\
\hline 0.0146 & 0.825832 & $5.55 \mathrm{e}-06$ & $1.71 \mathrm{e}-06$ & $7.17 \mathrm{e}-07$ \\
\hline 0.0159 & 0.813134 & $5.36 \mathrm{e}-06$ & $1.80 \mathrm{e}-06$ & $8.23 \mathrm{e}-07$ \\
\hline 0.0172 & 0.798425 & $5.17 \mathrm{e}-06$ & $1.88 \mathrm{e}-06$ & $9.31 \mathrm{e}-07$ \\
\hline 0.0186 & 0.78714 & $4.98 \mathrm{e}-06$ & $1.95 \mathrm{e}-06$ & $1.04 \mathrm{e}-06$ \\
\hline 0.0199 & 0.773749 & $4.80 \mathrm{e}-06$ & $2.02 \mathrm{e}-06$ & $1.15 \mathrm{e}-06$ \\
\hline 0.0212 & 0.762685 & $4.63 \mathrm{e}-06$ & $2.08 \mathrm{e}-06$ & $1.26 \mathrm{e}-06$ \\
\hline 0.0225 & 0.761001 & $4.47 \mathrm{e}-06$ & $2.13 \mathrm{e}-06$ & $1.37 \mathrm{e}-06$ \\
\hline 0.0238 & 0.751256 & $4.31 \mathrm{e}-06$ & $2.17 \mathrm{e}-06$ & $1.48 \mathrm{e}-06$ \\
\hline 0.0251 & 0.736999 & $4.16 \mathrm{e}-06$ & $2.21 \mathrm{e}-06$ & $1.59 \mathrm{e}-06$ \\
\hline 0.0278 & 0.727134 & $3.87 \mathrm{e}-06$ & $2.27 \mathrm{e}-06$ & $1.81 \mathrm{e}-06$ \\
\hline 0.0304 & 0.713694 & $3.61 \mathrm{e}-06$ & $2.32 \mathrm{e}-06$ & $2.02 \mathrm{e}-06$ \\
\hline 0.0343 & 0.697178 & $3.27 \mathrm{e}-06$ & $2.36 \mathrm{e}-06$ & $2.32 \mathrm{e}-06$ \\
\hline & & & & \\
\hline
\end{tabular}


Table S15 Results of the titration experiment of Ni-TPBF 203 at $293 \mathrm{~K}$.

\begin{tabular}{|c|c|c|c|c|}
\hline $\begin{array}{c}\text { Cethyl isonicotinate } \\
{[\mathbf{m o l} / \mathbf{L}]}\end{array}$ & $\mathbf{A} @ \mathbf{~} \mathbf{4 0 9} \mathbf{~ n m}$ & $\begin{array}{c}\mathbf{C}_{\mathbf{1 0}} \\
{[\mathbf{m o l} / \mathbf{L}]}\end{array}$ & $\begin{array}{c}\mathbf{C}_{\mathbf{1 0} \cdot \mathbf{E t O o c}-P \mathbf{y}} \\
{[\mathbf{m o l} / \mathbf{L}]}\end{array}$ & $\begin{array}{c}\mathbf{C}_{\mathbf{1 0} \cdot \mathbf{2 E t O O C}-\mathbf{P y}} \\
{[\mathbf{m o l} / \mathbf{L}]}\end{array}$ \\
\hline 0 & 0.65718 & $8.01 \mathrm{e}-06$ & 0 & 0 \\
\hline 0.00002 & 0.653797 & $7.97 \mathrm{e}-06$ & $2.70 \mathrm{e}-08$ & $6.75 \mathrm{e}-11$ \\
\hline 0.00029 & 0.635102 & $7.63 \mathrm{e}-06$ & $3.35 \mathrm{e}-07$ & $1.09 \mathrm{e}-08$ \\
\hline 0.00082 & 0.585311 & $7.02 \mathrm{e}-06$ & $8.77 \mathrm{e}-07$ & $8.10 \mathrm{e}-08$ \\
\hline 0.00135 & 0.535077 & $6.44 \mathrm{e}-06$ & $1.33 \mathrm{e}-06$ & $2.02 \mathrm{e}-07$ \\
\hline 0.00214 & 0.468945 & $5.67 \mathrm{e}-06$ & $1.85 \mathrm{e}-06$ & $4.49 \mathrm{e}-07$ \\
\hline 0.00320 & 0.396969 & $4.78 \mathrm{e}-06$ & $2.34 \mathrm{e}-06$ & $8.45 \mathrm{e}-07$ \\
\hline 0.00426 & 0.336947 & $4.05 \mathrm{e}-06$ & $2.64 \mathrm{e}-06$ & $1.27 \mathrm{e}-06$ \\
\hline 0.00532 & 0.290184 & $3.46 \mathrm{e}-06$ & $2.81 \mathrm{e}-06$ & $1.68 \mathrm{e}-06$ \\
\hline 0.00637 & 0.24804 & $2.97 \mathrm{e}-06$ & $2.89 \mathrm{e}-06$ & $2.08 \mathrm{e}-06$ \\
\hline 0.00742 & 0.216533 & $2.58 \mathrm{e}-06$ & $2.92 \mathrm{e}-06$ & $2.44 \mathrm{e}-06$ \\
\hline 0.00847 & 0.190663 & $2.25 \mathrm{e}-06$ & $2.91 \mathrm{e}-06$ & $2.78 \mathrm{e}-06$ \\
\hline 0.00952 & 0.166974 & $1.97 \mathrm{e}-06$ & $2.87 \mathrm{e}-06$ & $3.08 \mathrm{e}-06$ \\
\hline 0.01057 & 0.149981 & $1.75 \mathrm{e}-06$ & $2.82 \mathrm{e}-06$ & $3.36 \mathrm{e}-06$ \\
\hline 0.01161 & 0.134534 & $1.55 \mathrm{e}-06$ & $2.75 \mathrm{e}-06$ & $3.61 \mathrm{e}-06$ \\
\hline 0.01318 & 0.117653 & $1.32 \mathrm{e}-06$ & $2.65 \mathrm{e}-06$ & $3.94 \mathrm{e}-06$ \\
\hline 0.01526 & 0.09916 & $1.07 \mathrm{e}-06$ & $2.50 \mathrm{e}-06$ & $4.31 \mathrm{e}-06$ \\
\hline 0.01837 & 0.079252 & $8.18 \mathrm{e}-07$ & $2.30 \mathrm{e}-06$ & $4.76 \mathrm{e}-06$ \\
\hline 0.02351 & 0.060324 & $5.55 \mathrm{e}-07$ & $1.99 \mathrm{e}-06$ & $5.29 \mathrm{e}-06$ \\
\hline 0.03369 & 0.038935 & $3.02 \mathrm{e}-07$ & $1.56 \mathrm{e}-06$ & $5.92 \mathrm{e}-06$ \\
\hline 0.05936 & 0.020567 & $1.09 \mathrm{e}-07$ & $9.92 \mathrm{e}-07$ & $6.65 \mathrm{e}-06$ \\
\hline 0.11011 & 0.012197 & $3.39 \mathrm{e}-08$ & $5.70 \mathrm{e}-07$ & $7.09 \mathrm{e}-06$ \\
\hline 0.20930 & 0.007865 & $9.60 \mathrm{e}-09$ & $3.07 \mathrm{e}-07$ & $7.26 \mathrm{e}-06$ \\
\hline & & & & \\
\hline
\end{tabular}

Table S16 Results of the titration experiment of Ni-TPBF 203 at $298 \mathrm{~K}$.

\begin{tabular}{|c|c|c|c|c|}
\hline $\begin{array}{c}\text { Cethyl isonicotinate } \\
{[\mathbf{m o l} / \mathbf{L}]}\end{array}$ & $\mathbf{A}$ @ 409 nm & $\begin{array}{c}\mathbf{C}_{\mathbf{1 0}} \\
{[\mathbf{m o l} / \mathbf{L}]}\end{array}$ & $\begin{array}{c}\mathbf{C}_{\mathbf{1 0} \cdot \mathbf{E t O o c}-\mathbf{P y}} \\
{[\mathbf{m o l} / \mathbf{L}]}\end{array}$ & $\begin{array}{c}\mathbf{C}_{\mathbf{1 0} \cdot \mathbf{2 E t O O C}-\mathbf{P y}} \\
{[\mathbf{m o l} / \mathbf{L}]}\end{array}$ \\
\hline 0 & 0.633992 & $8.01 \mathrm{e}-06$ & 0 & 0 \\
\hline 0.00002 & 0.63147 & $7.97 \mathrm{e}-06$ & $2.17 \mathrm{e}-08$ & $5.47 \mathrm{e}-11$ \\
\hline 0.00029 & 0.616044 & $7.7 \mathrm{e}-06$ & $2.72 \mathrm{e}-07$ & $8.89 \mathrm{e}-09$ \\
\hline 0.00082 & 0.57611 & $7.19 \mathrm{e}-06$ & $7.23 \mathrm{e}-07$ & $6.72 \mathrm{e}-08$ \\
\hline 0.00135 & 0.534275 & $6.69 \mathrm{e}-06$ & $1.11 \mathrm{e}-06$ & $1.70 \mathrm{e}-07$ \\
\hline 0.00214 & 0.480946 & $6.00 \mathrm{e}-06$ & $1.58 \mathrm{e}-06$ & $3.85 \mathrm{e}-07$ \\
\hline 0.00320 & 0.420376 & $5.18 \mathrm{e}-06$ & $2.04 \mathrm{e}-06$ & $7.41 \mathrm{e}-07$ \\
\hline 0.00426 & 0.366084 & $4.48 \mathrm{e}-06$ & $2.35 \mathrm{e}-06$ & $1.13 \mathrm{e}-06$ \\
\hline 0.00532 & 0.319951 & $3.88 \mathrm{e}-06$ & $2.54 \mathrm{e}-06$ & $1.53 \mathrm{e}-06$ \\
\hline 0.00637 & 0.277872 & $3.38 \mathrm{e}-06$ & $2.65 \mathrm{e}-06$ & $1.91 \mathrm{e}-06$ \\
\hline 0.00742 & 0.243145 & $2.96 \mathrm{e}-06$ & $2.70 \mathrm{e}-06$ & $2.27 \mathrm{e}-06$ \\
\hline 0.00847 & 0.217603 & $2.61 \mathrm{e}-06$ & $2.72 \mathrm{e}-06$ & $2.61 \mathrm{e}-06$ \\
\hline 0.00952 & 0.194433 & $2.31 \mathrm{e}-06$ & $2.70 \mathrm{e}-06$ & $2.92 \mathrm{e}-06$ \\
\hline 0.01057 & 0.175287 & $2.05 \mathrm{e}-06$ & $2.67 \mathrm{e}-06$ & $3.20 \mathrm{e}-06$ \\
\hline 0.01161 & 0.159156 & $1.84 \mathrm{e}-06$ & $2.62 \mathrm{e}-06$ & $3.45 \mathrm{e}-06$ \\
\hline 0.01318 & 0.138164 & $1.57 \mathrm{e}-06$ & $2.54 \mathrm{e}-06$ & $3.80 \mathrm{e}-06$ \\
\hline 0.01526 & 0.117943 & $1.29 \mathrm{e}-06$ & $2.42 \mathrm{e}-06$ & $4.18 \mathrm{e}-06$ \\
\hline 0.01837 & 0.098409 & $9.88 \mathrm{e}-07$ & $2.23 \mathrm{e}-06$ & $4.65 \mathrm{e}-06$ \\
\hline 0.02351 & 0.076054 & $6.76 \mathrm{e}-07$ & $1.95 \mathrm{e}-06$ & $5.21 \mathrm{e}-06$ \\
\hline 0.03369 & 0.053094 & $3.71 \mathrm{e}-07$ & $1.54 \mathrm{e}-06$ & $5.87 \mathrm{e}-06$ \\
\hline 0.05936 & 0.031797 & $1.35 \mathrm{e}-07$ & $9.84 \mathrm{e}-07$ & $6.63 \mathrm{e}-06$ \\
\hline 0.11011 & 0.020971 & $4.18 \mathrm{e}-08$ & $5.67 \mathrm{e}-07$ & $7.08 \mathrm{e}-06$ \\
\hline 0.20930 & 0.01681 & $1.19 \mathrm{e}-08$ & $3.05 \mathrm{e}-07$ & $7.26 \mathrm{e}-06$ \\
\hline & & & & \\
\hline
\end{tabular}


Table S17 Results of the titration experiment of Ni-TPBF 203 at $303 \mathrm{~K}$.

\begin{tabular}{|c|c|c|c|c|}
\hline $\begin{array}{c}\text { Cethyl isonicotinate } \\
{[\mathbf{m o l} / \mathbf{L}]}\end{array}$ & $\mathbf{A}$ @ $\mathbf{4 0 9} \mathbf{~ n m}$ & $\begin{array}{c}\mathbf{C}_{\mathbf{1 0}} \\
{[\mathbf{m o l} / \mathbf{L}]}\end{array}$ & $\begin{array}{c}\mathbf{C}_{\mathbf{1 0} \cdot \mathbf{E t O O C}-P \mathbf{y}} \\
{[\mathbf{m o l} / \mathbf{L}]}\end{array}$ & $\begin{array}{c}\mathbf{C}_{\mathbf{1 0} \cdot \mathbf{E} \text { Etooc-Py }} \\
{[\mathbf{m o l} / \mathbf{L}]}\end{array}$ \\
\hline 0 & 0.643404 & $8.01 \mathrm{E}-06$ & 0 & 0 \\
\hline 0.00002 & 0.643644 & $7.98 \mathrm{E}-06$ & $1.75 \mathrm{E}-08$ & $2.89 \mathrm{E}-11$ \\
\hline 0.00029 & 0.629626 & $7.75 \mathrm{E}-06$ & $2.21 \mathrm{E}-07$ & $4.73 \mathrm{E}-09$ \\
\hline 0.00082 & 0.601921 & $7.35 \mathrm{E}-06$ & $5.96 \mathrm{E}-07$ & $3.62 \mathrm{E}-08$ \\
\hline 0.00135 & 0.562848 & $6.95 \mathrm{E}-06$ & $9.29 \mathrm{E}-07$ & $9.32 \mathrm{E}-08$ \\
\hline 0.00214 & 0.52072 & $6.39 \mathrm{E}-06$ & $1.36 \mathrm{E}-06$ & $2.16 \mathrm{E}-07$ \\
\hline 0.00320 & 0.465314 & $5.72 \mathrm{E}-06$ & $1.81 \mathrm{E}-06$ & $4.32 \mathrm{E}-07$ \\
\hline 0.00426 & 0.416612 & $5.12 \mathrm{E}-06$ & $2.16 \mathrm{E}-06$ & $6.83 \mathrm{E}-07$ \\
\hline 0.00532 & 0.371335 & $4.58 \mathrm{E}-06$ & $2.41 \mathrm{E}-06$ & $9.53 \mathrm{E}-07$ \\
\hline 0.00637 & 0.336958 & $4.12 \mathrm{E}-06$ & $2.60 \mathrm{E}-06$ & $1.23 \mathrm{E}-06$ \\
\hline 0.00742 & 0.303554 & $3.71 \mathrm{E}-06$ & $2.73 \mathrm{E}-06$ & $1.50 \mathrm{E}-06$ \\
\hline 0.00847 & 0.27463 & $3.35 \mathrm{E}-06$ & $2.81 \mathrm{E}-06$ & $1.77 \mathrm{E}-06$ \\
\hline 0.00952 & 0.239887 & $3.04 \mathrm{E}-06$ & $2.86 \mathrm{E}-06$ & $2.03 \mathrm{E}-06$ \\
\hline 0.01057 & 0.226996 & $2.76 \mathrm{E}-06$ & $2.89 \mathrm{E}-06$ & $2.27 \mathrm{E}-06$ \\
\hline 0.01161 & 0.205665 & $2.52 \mathrm{E}-06$ & $2.90 \mathrm{E}-06$ & $2.50 \mathrm{E}-06$ \\
\hline 0.01318 & 0.182096 & $2.21 \mathrm{E}-06$ & $2.88 \mathrm{E}-06$ & $2.82 \mathrm{E}-06$ \\
\hline 0.01526 & 0.158088 & $1.87 \mathrm{E}-06$ & $2.82 \mathrm{E}-06$ & $3.20 \mathrm{E}-06$ \\
\hline 0.01837 & 0.129359 & $1.48 \mathrm{E}-06$ & $2.70 \mathrm{E}-06$ & $3.69 \mathrm{E}-06$ \\
\hline 0.02351 & 0.097704 & $1.06 \mathrm{E}-06$ & $2.47 \mathrm{E}-06$ & $4.31 \mathrm{E}-06$ \\
\hline 0.03369 & 0.065377 & $6.13 \mathrm{E}-07$ & $2.05 \mathrm{E}-06$ & $5.12 \mathrm{E}-06$ \\
\hline 0.05936 & 0.033649 & $2.36 \mathrm{E}-07$ & $1.39 \mathrm{E}-06$ & $6.13 \mathrm{E}-06$ \\
\hline 0.11011 & 0.018239 & $7.59 \mathrm{E}-08$ & $8.29 \mathrm{E}-07$ & $6.79 \mathrm{E}-06$ \\
\hline 0.20930 & 0.012637 & $2.20 \mathrm{E}-08$ & $4.56 \mathrm{E}-07$ & $7.10 \mathrm{E}-06$ \\
\hline & & & & \\
\hline
\end{tabular}
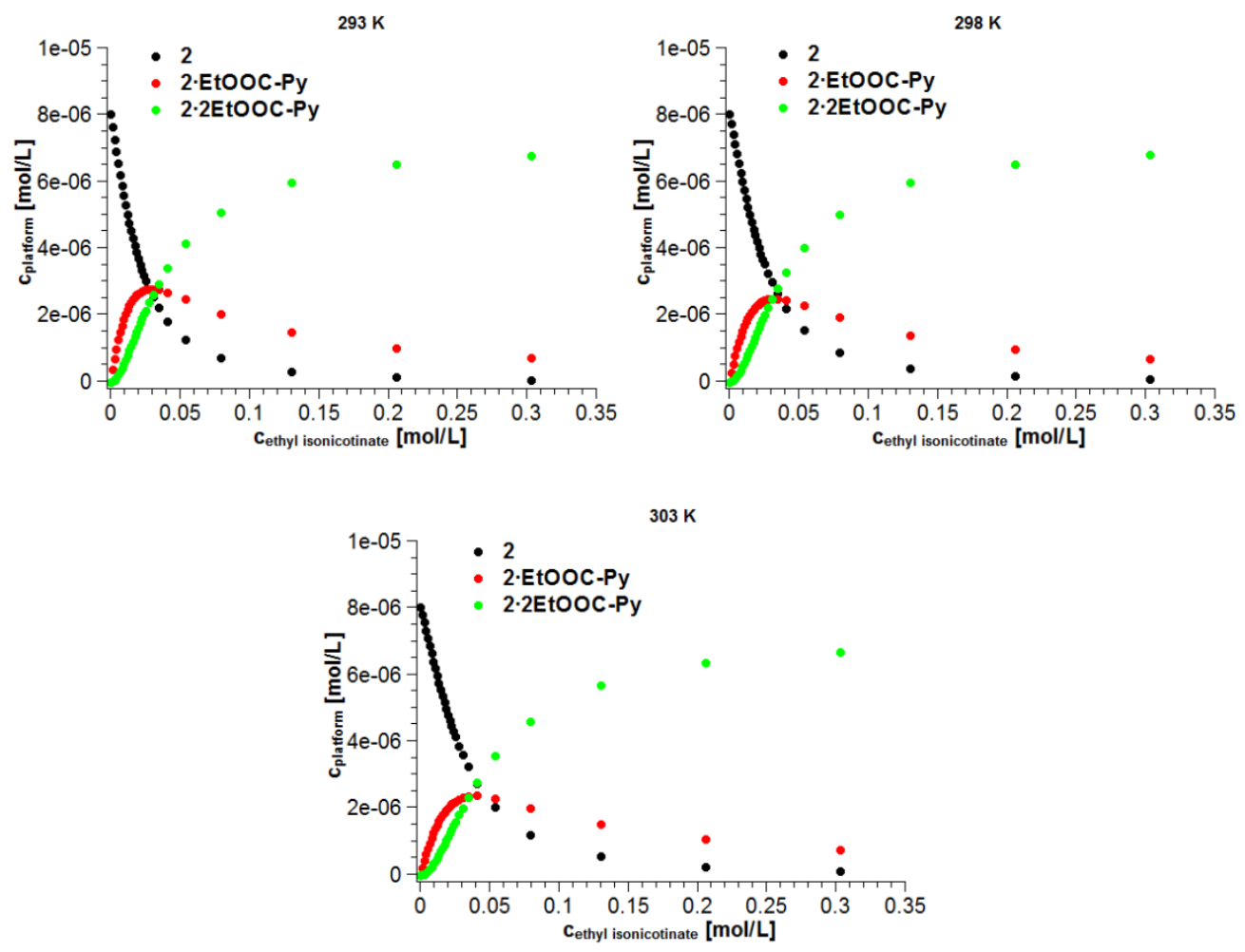

Fig. S32 Concentrations of the complexes 2, 2·EtOOC-Py and 2-2EtOOC-Py as a function of the added ethyl isonicotinate in the titration experiment in toluene at different temperatures. 

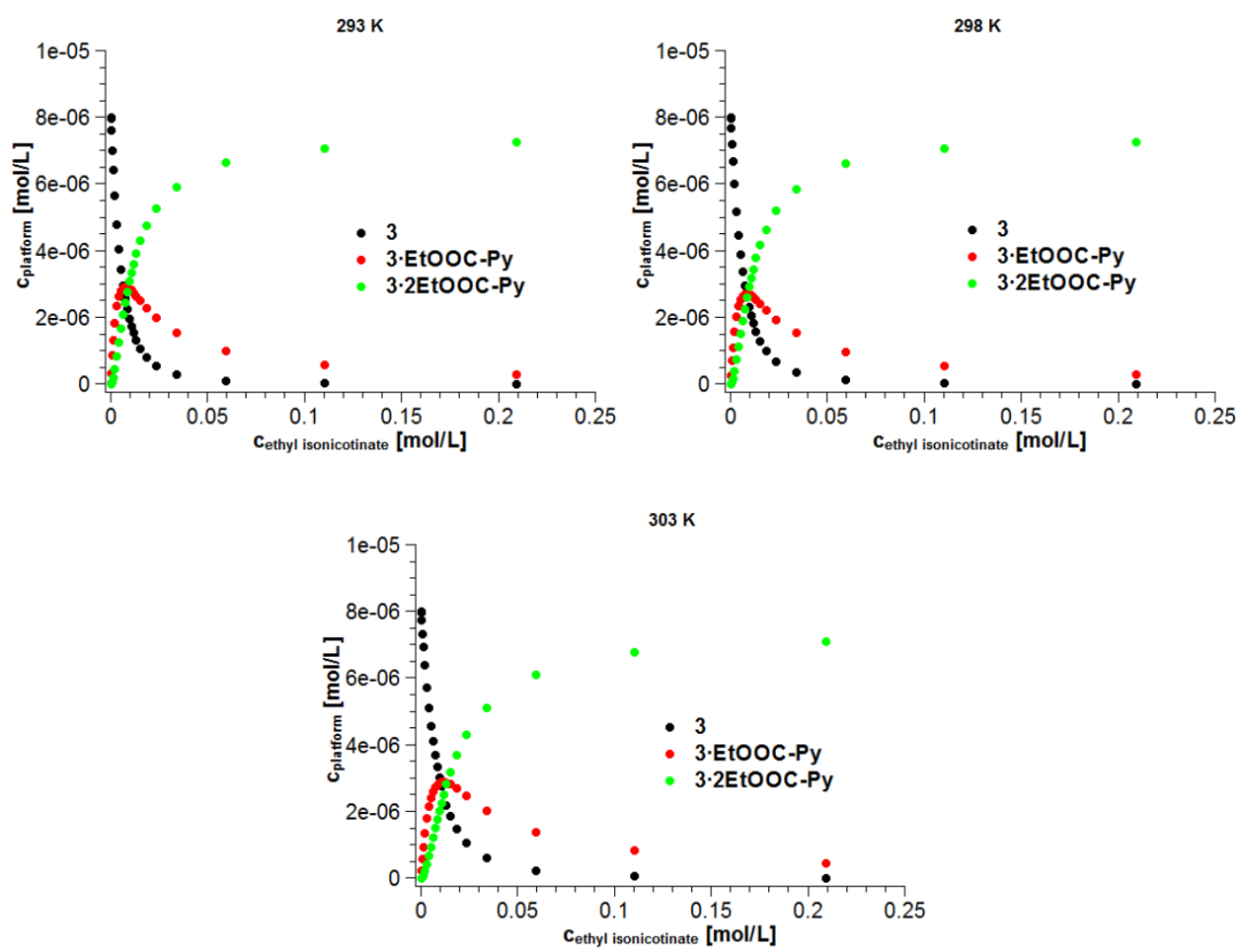

Fig. S33 Concentrations of the complexes 3, 3·EtOOC-Py and 3·2EtOOC-Py as a function of the added ethyl isonicotinate in the titration experiment in toluene at different temperatures.

The values for $K_{1}$ and $K_{2}$ in the titration experiment with ethyl isonicotinate are smaller compared to the corresponding association constants of the coordination of pyridine (table S18).

Table S18 Results for the association constants $\left(\mathrm{K}_{1 \mathrm{~S}}, \mathrm{~K}_{2}\right)$ of Ni(II) chlorin (2, Ni-TPCF 20$)$ and Ni(II) bacteriochlorin $\left(3, \mathrm{Ni}-\mathrm{TPCF}_{20}\right)$ with ethyl isonicotinate at different temperatures.

\begin{tabular}{|c|c|c|c|c|c|}
\hline compound & $\begin{array}{c}\mathbf{T} \\
{[\mathrm{K}]}\end{array}$ & $\begin{array}{c}\mathbf{T}^{-1} \\
{\left[\mathbf{K}^{-1}\right]}\end{array}$ & $\begin{array}{c}\mathrm{K}_{1 \mathrm{~s}} \\
{\left[\mathrm{~L} \mathrm{~mol}^{-1}\right]}\end{array}$ & $\begin{array}{c}\mathrm{K}_{2} \\
{\left[\mathrm{~L} \mathrm{~mol}^{-1}\right]}\end{array}$ & $\ln K_{1 s}$ \\
\hline & 293 & 0.003355705 & 36.09 & 31.01 & 3.585956543 \\
\hline $\mathrm{Ni}-\mathrm{TPCF}_{20}$ & 298 & 0.003246753 & 27.49 & 32.61 & 3.313698742 \\
\hline & 303 & 0.003144654 & 21.14 & 28.66 & 3.051270716 \\
\hline & 293 & 0.003355705 & 152.85 & 112.95 & 5.029449318 \\
\hline $\mathrm{Ni}-\mathrm{TPBF}_{20}$ & 298 & 0.003246753 & 123.05 & 113.54 & 4.812581476 \\
\hline 3 & 303 & 0.003144654 & 99.15 & 74.36 & 4.596611193 \\
\hline
\end{tabular}

The plots $\ln \mathrm{K}$ against 1/T are shown in Fig. S34. All values are summarized in table S19. 

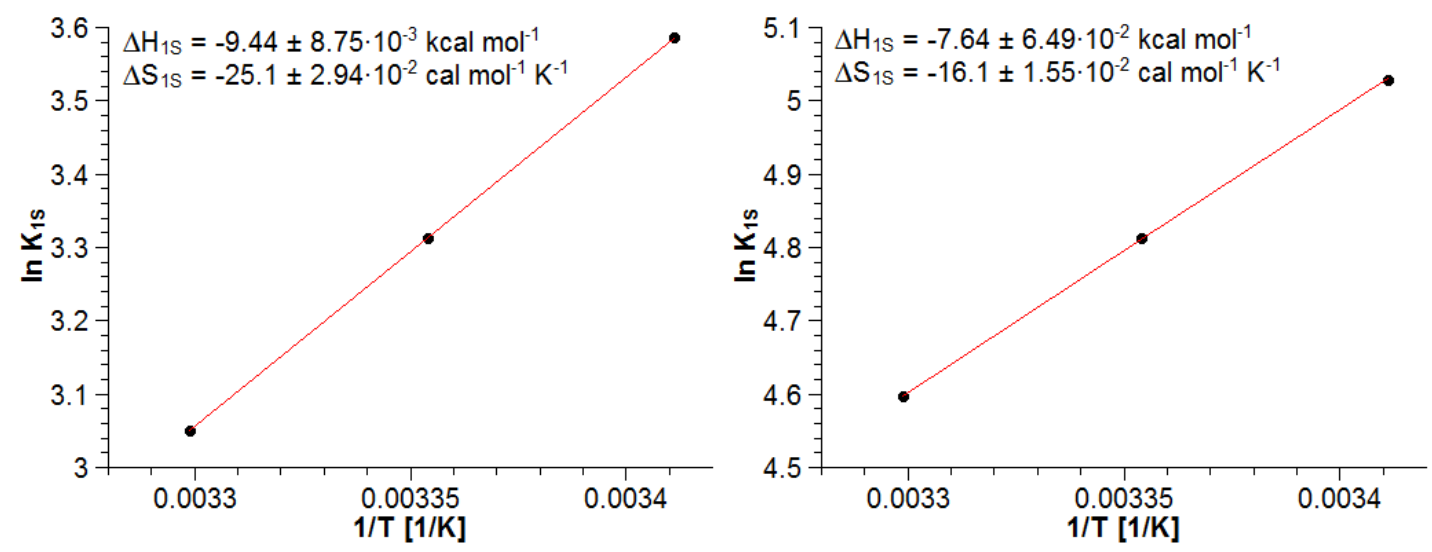

Fig. S34 Plots of $\ln K_{1 s}$ against $1 / T$ for determination of the thermodynamic parameters $\Delta H$ and $\Delta S$ for Ni(II) chlorin 2 (left) and Ni(II) bacteriochlorin 3 (right).

Table S19 Determined association constants $\left(K_{1 S}, K_{2}\right.$ and $K_{\beta}$ with $\left.\beta=K_{1 S} \cdot K_{2}\right)$ of the coordination of ethyl isonicotinate with EST and thermodynamic parameters of the platforms $\mathbf{2}$ and $\mathbf{3}$.

\begin{tabular}{|c|c|c|c|c|c|c|}
\hline \multirow[b]{2}{*}{ temperature [K] } & \multicolumn{3}{|c|}{$\mathrm{Ni}^{-T C_{2}}$} & \multicolumn{3}{|c|}{$\mathrm{Ni}^{-\mathrm{TPBF}_{20}}$} \\
\hline & 293 & 298 & 303 & 293 & 298 & 303 \\
\hline $\mathrm{K}_{1 \mathrm{~S}}\left[\mathrm{~L} \cdot \mathrm{mol}^{-1}\right]$ & 36.09 & 27.49 & 21.14 & 152.85 & 123.05 & 99.15 \\
\hline $\mathrm{K}_{2}\left[\mathrm{~L} \cdot \mathrm{mol}^{-1}\right]$ & 31.01 & 32.61 & 28.66 & 112.95 & 113.54 & 74.36 \\
\hline$\beta\left[\mathbf{L}^{2} \cdot \mathbf{m o l}^{-2}\right]$ & 1119.13 & 896.26 & 605.84 & 17264.32 & 13970.70 & 7372.65 \\
\hline $\begin{array}{c}\Delta \mathbf{H}_{1 \mathrm{~s}} \\
{\left[\mathrm{kcal} \cdot \mathrm{mol}^{-1}\right]}\end{array}$ & \multicolumn{3}{|c|}{$-9.44 \pm 8.75 \cdot 10^{-3}$} & \multicolumn{3}{|c|}{$-7.64 \pm 6.49 \cdot 10^{-2}$} \\
\hline $\begin{array}{c}\Delta \mathbf{S}_{1 \mathrm{~S}} \\
{\left[\mathrm{cal} \cdot \mathbf{m o l}^{-1} \cdot \mathbf{K}^{-1}\right]}\end{array}$ & \multicolumn{3}{|c|}{$-25.1 \pm 2.94 \cdot 10^{-2}$} & \multicolumn{3}{|c|}{$-16.1 \pm 1.55 \cdot 10^{-2}$} \\
\hline
\end{tabular}




\section{Single Crystal X-Ray Diffraction Analysis}

\section{IV.1 Selected Crystal Data of Compounds 6a-Ni, 3 and 3·Py2}

Table 20 Selected crystal data and details of the single crystal structure refinements for compounds 6a-Ni, 3 and $3 \cdot \mathbf{P y}_{2}$

\begin{tabular}{|c|c|c|c|}
\hline compound & Compound 6a-Ni & Compound 3 & Compound $3 \cdot P_{2}$ \\
\hline Formula & $\mathrm{C}_{58} \mathrm{H}_{30} \mathrm{BF}_{15} \mathrm{~N}_{4} \mathrm{NiO}_{3}$ & $\mathrm{C}_{60} \mathrm{H}_{20} \mathrm{~F}_{20} \mathrm{~N}_{4} \mathrm{NiO}_{2}$ & $\mathrm{C}_{70} \mathrm{H}_{30} \mathrm{~F}_{20} \mathrm{~N}_{6} \mathrm{NiO}_{2}$ \\
\hline $\mathrm{MW} / \mathrm{g} \mathrm{mol}^{-1}$ & 1185.38 & 1267.51 & 1425.71 \\
\hline crystal system & Monoclinic & Orthorhombic & Monoclinic \\
\hline space group & $P 2_{1} / C$ & Pnma & $P 2_{1 / n}$ \\
\hline$a / \AA$ & $15.0131(4)$ & 13.9376(3) & $14.0672(3)$ \\
\hline$b / \AA$ & 27.8235(9) & 27.7386(8) & $20.2475(4)$ \\
\hline$c / \AA$ & $14.6178(4)$ & 13.8164(3) & 25.1372(5) \\
\hline$\alpha /^{\circ}$ & 90 & 90 & 90 \\
\hline$\beta / \circ$ & $108.508(2)$ & 90 & $98.422(1)$ \\
\hline$\gamma /{ }^{\circ}$ & 90 & 90 & 90 \\
\hline$V / \AA^{3}$ & $5790.3(3)$ & $5341.6(2)$ & $7082.5(3)$ \\
\hline$T / \mathrm{K}$ & 170 & 170 & 170 \\
\hline$Z$ & 4 & 4 & 4 \\
\hline$D_{\text {calc }} / \mathrm{g} \mathrm{cm}^{-3}$ & 1.360 & 1.576 & 1.560 \\
\hline$\mu / \mathrm{mm}^{-1}$ & 0.429 & 0.483 & 0.387 \\
\hline$\theta_{\max } / \operatorname{deg}$ & 25 & 25.187 & 26 \\
\hline measured refl. & 50668 & 28274 & 67572 \\
\hline unique refl. & 10213 & 4899 & 13857 \\
\hline$R_{\text {int }}$ & 0.1448 & 0.0282 & 0.0693 \\
\hline refl. $\left[F_{0}>4 \sigma\left(F_{0}\right)\right]$ & 6158 & 4319 & 12196 \\
\hline parameters & 793 & 499 & 1001 \\
\hline$R_{1}\left[F_{0}>4 \sigma\left(F_{0}\right)\right]$ & 0.778 & 0.0327 & 0.0642 \\
\hline$w R_{2}$ [all data] & 0.1871 & 0.0852 & 0.1624 \\
\hline GOF & 1.029 & 1.057 & 1.103 \\
\hline$\Delta \rho_{\max / \min } /$ e $\AA^{-3}$ & $0.376 /-0.323$ & $0.245 /-0.297$ & $0.388 /-0.706$ \\
\hline
\end{tabular}

CCDC 2061746 (Compound 3), CCDC 2061747 (Compound 3·Py ) $_{\text {) }}$ and CCDC 2061748

(Compound 6a-Ni) contain the supplementary crystallographic data for this paper. These data can be obtained free charge from the Cambridge Crystallographic Data Centre via http://www.ccdc.cam.ac.uk/data_request/cif.

For crystal preparation a pure sample $(20 \mathrm{mg}$ ) of the following compounds was dissolved in a 1:1 mixture of toluene/dichloromethane (compounds $\mathbf{6 a - N i}$ and 3 ) or in pyridine/dichloromethane (compound $\mathbf{3 \cdot 2 P y}$ ). Within 14 days crystals usable for crystal structure determination were obtained by slow evaporation of the solvent. 


\section{IV.2 Structural Details for Compound 6a-Ni}

Data collection was performed with an IPDS2 from STOE \& CIE using $\mathrm{MoK}_{\alpha}$ radiation $(\lambda=0.17073 \AA)$. The structure was solved with SHELXT and refinement was performed using SHELXL-2018. All non-hydrogen atoms were refined anisotropic. The C-H H atoms were positioned with idealized geometry and refined isotropic with $\mathrm{U}_{\text {iso }}(\mathrm{H})=1.2 \mathrm{Ueq}(\mathrm{C})$ using a riding model. After structure refinement there are some small residual electron density peaks, indicating for disordered solvent. Therefore, its contribution to the electron density was removed using Squeeze in Platon. The low reliability factors can be traced back to the very low scattering power of the crystal.

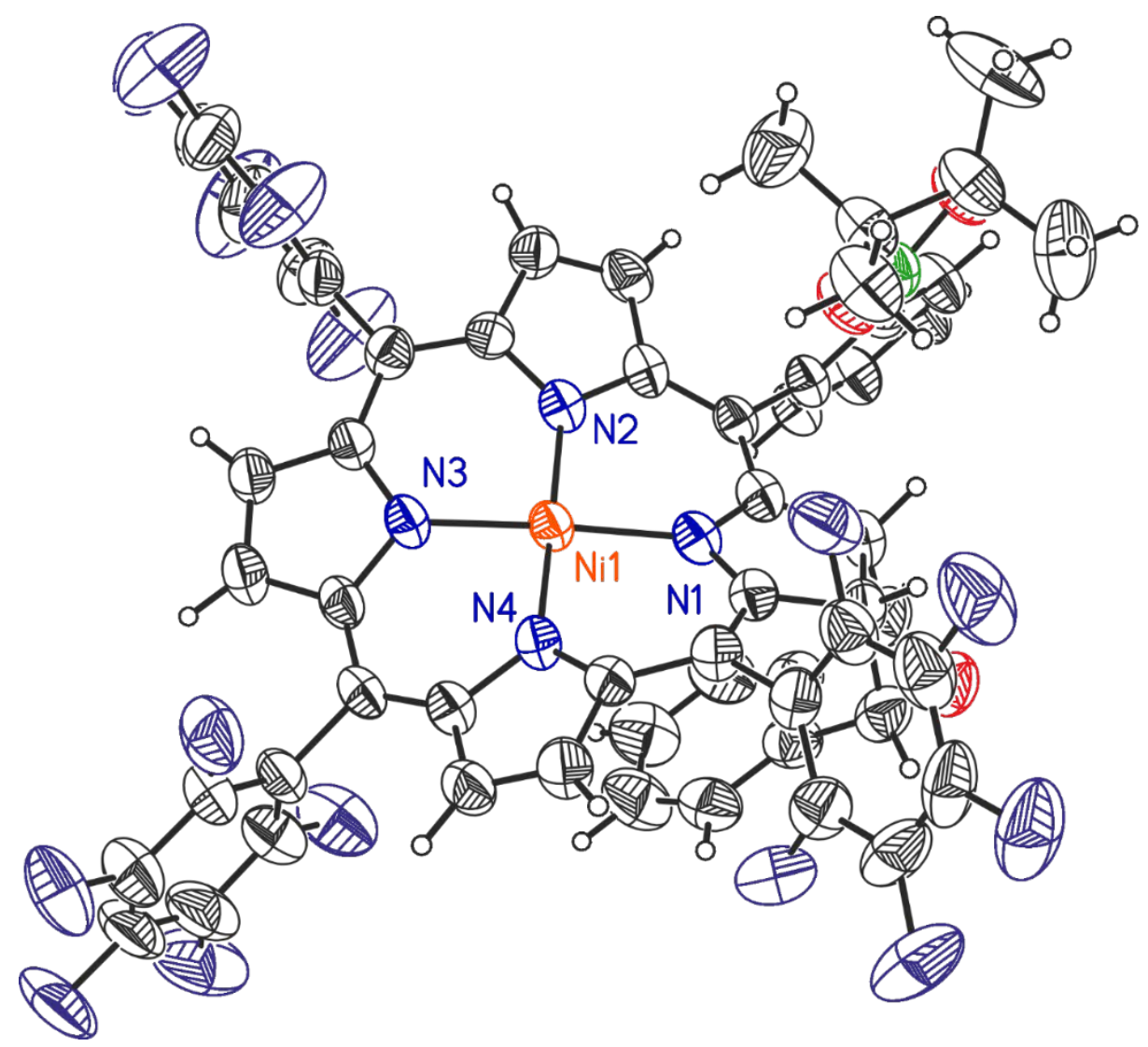

Fig. S35 Crystal structure of 6a-Ni with labeling and displacement ellipsoids drawn at the $50 \%$ probability level. Color codes: Ni: orange, N: blue, F: violet, O: red, B: green.

Table S21 Bond lengths $[\AA]$ and angles $\left[{ }^{\circ}\right]$ for $\mathbf{6 a}-\mathbf{N i}$.

\begin{tabular}{cc|cc}
$\mathrm{Ni}(1)-\mathrm{N}(4)$ & $1.895(4)$ & $\mathrm{Ni}(1)-\mathrm{N}(3)$ & $1.922(4)$ \\
$\mathrm{Ni}(1)-\mathrm{N}(2)$ & $1.903(4)$ & $\mathrm{Ni}(1)-\mathrm{N}(1)$ & $1.930(4)$ \\
$\mathrm{N}(4)-\mathrm{Ni}(1)-\mathrm{N}(2)$ & $174.56(18)$ & $\mathrm{N}(4)-\mathrm{Ni}(1)-\mathrm{N}(1)$ & $89.84(17)$ \\
$\mathrm{N}(4)-\mathrm{Ni}(1)-\mathrm{N}(3)$ & $90.22(16)$ & $\mathrm{N}(2)-\mathrm{Ni}(1)-\mathrm{N}(1)$ & $90.77(17)$ \\
$\mathrm{N}(2)-\mathrm{Ni}(1)-\mathrm{N}(3)$ & $89.65(17)$ & $\mathrm{N}(3)-\mathrm{Ni}(1)-\mathrm{N}(1)$ & $174.93(18)$
\end{tabular}




\section{IV.3 Structural Details for Compound 3}

Data collection was performed with an IPDS2 from STOE \& CIE using $\mathrm{MoK}_{\alpha}$ radiation $(\lambda=0.17073 \AA)$. The structure was solved with SHELXT and refinement was performed using SHELXL-2018. The data were correct for adsorption using X-Red and X-Shape as part of the program package X-Area (Tmin/max: 0.8598/0.9396). All atoms were refined anisotropic. The $\mathrm{C}-\mathrm{H}$ and $\mathrm{N}-\mathrm{H} \mathrm{H}$ atoms were positioned with idealized geometry and refined isotropic with $\mathrm{U}_{\text {iso }}(\mathrm{H})=1.2 \mathrm{Ueq}(\mathrm{C}, \mathrm{N})$ using a riding model. One of the pentafluoro phenyl rings is disordered in two orientations and was refined using a split model using restraints for the geometry (SAME) and for the components of the anisotropic displacement parameters (SIMU, DELU). After structure refinement there are some small residual electron density peaks, indicating for disordered solvent. Therefore, its contribution to the electron density was removed using Squeeze in Platon.

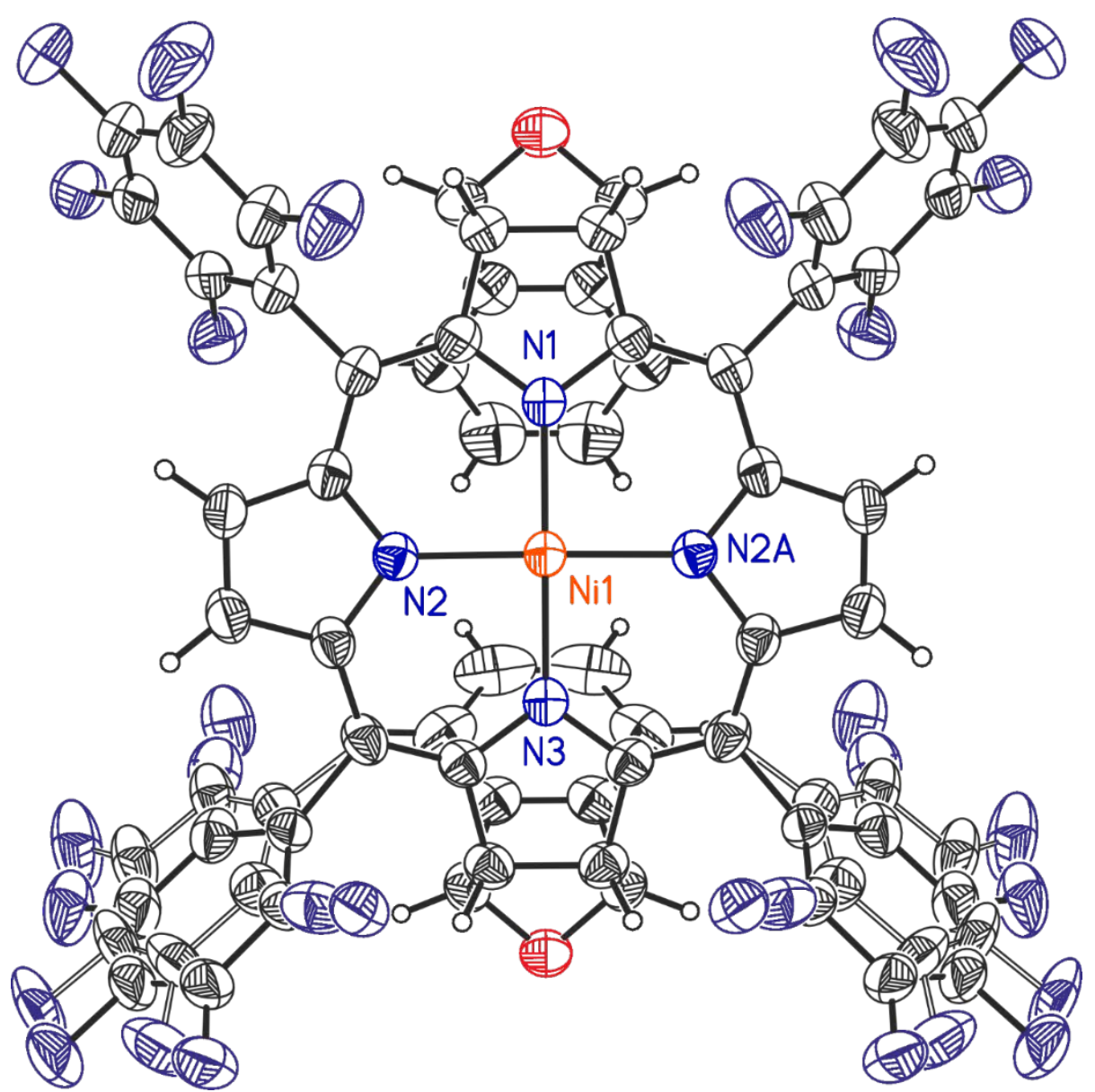

Fig. S36 Crystal structure of 3 with labeling and displacement ellipsoids drawn at the 50\% probability level. Color codes: Ni: orange, N: blue, F: violet, O: red.

Table S22 Bond lengths $[\AA]$ and angles $\left[{ }^{\circ}\right]$ for 3 . Symmetry transformations used to generate equivalent atoms: $A: x,-y+3 / 2, z$.

$\begin{array}{cc}\mathrm{Ni}(1)-\mathrm{N}(2) \mathrm{A} & 1.9437(14) \\ \mathrm{Ni}(1)-\mathrm{N}(2) & 1.9437(14) \\ \mathrm{N}(2) \mathrm{A}-\mathrm{Ni}(1)-\mathrm{N}(2) & 171.12(8) \\ \mathrm{N}(2) \mathrm{A}-\mathrm{Ni}(1)-\mathrm{N}(1) & 90.03(4) \\ \mathrm{N}(2)-\mathrm{Ni}(1)-\mathrm{N}(1) & 90.03(4)\end{array}$

$\begin{array}{cc}\mathrm{Ni}(1)-\mathrm{N}(1) & 1.979(2) \\ \mathrm{Ni}(1)-\mathrm{N}(3) & 1.991(2) \\ \mathrm{N}(2) \mathrm{A}-\mathrm{Ni}(1)-\mathrm{N}(3) & 90.56(4) \\ \mathrm{N}(2)-\mathrm{Ni}(1)-\mathrm{N}(3) & 90.56(4) \\ \mathrm{N}(1)-\mathrm{Ni}(1)-\mathrm{N}(3) & 172.40(8)\end{array}$




\section{IV.4 Structural Details for Compound 3·Py2}

Data collection was performed with an IPDS2 from STOE \& CIE using $\mathrm{MoK}_{\alpha}$ radiation $(\lambda=0.17073 \AA)$. The structure was solved with SHELXT and refinement was performed using SHELXL-2018. The data were correct for adsorption using X-Red and X-Shape as part of the program package X-Area (Tmin/max: 0.8218/0.9718). All atoms were refined anisotropic. The C-H H atoms were positioned with idealized geometry and refined isotropic with $\mathrm{U}_{\text {iso }}(\mathrm{H})=1.2 \mathrm{Ueq}(\mathrm{C}, \mathrm{N})$ using a riding model. The asymmetric unit contain additional three pyridine solvate molecules, of which one is disordered. Because no reasonable split model was found the contribution of the third solvate molecules to the electron density was removed using Squeeze in Platon. However, this molecule was considered in the calculation of the formula and the molecular weight.

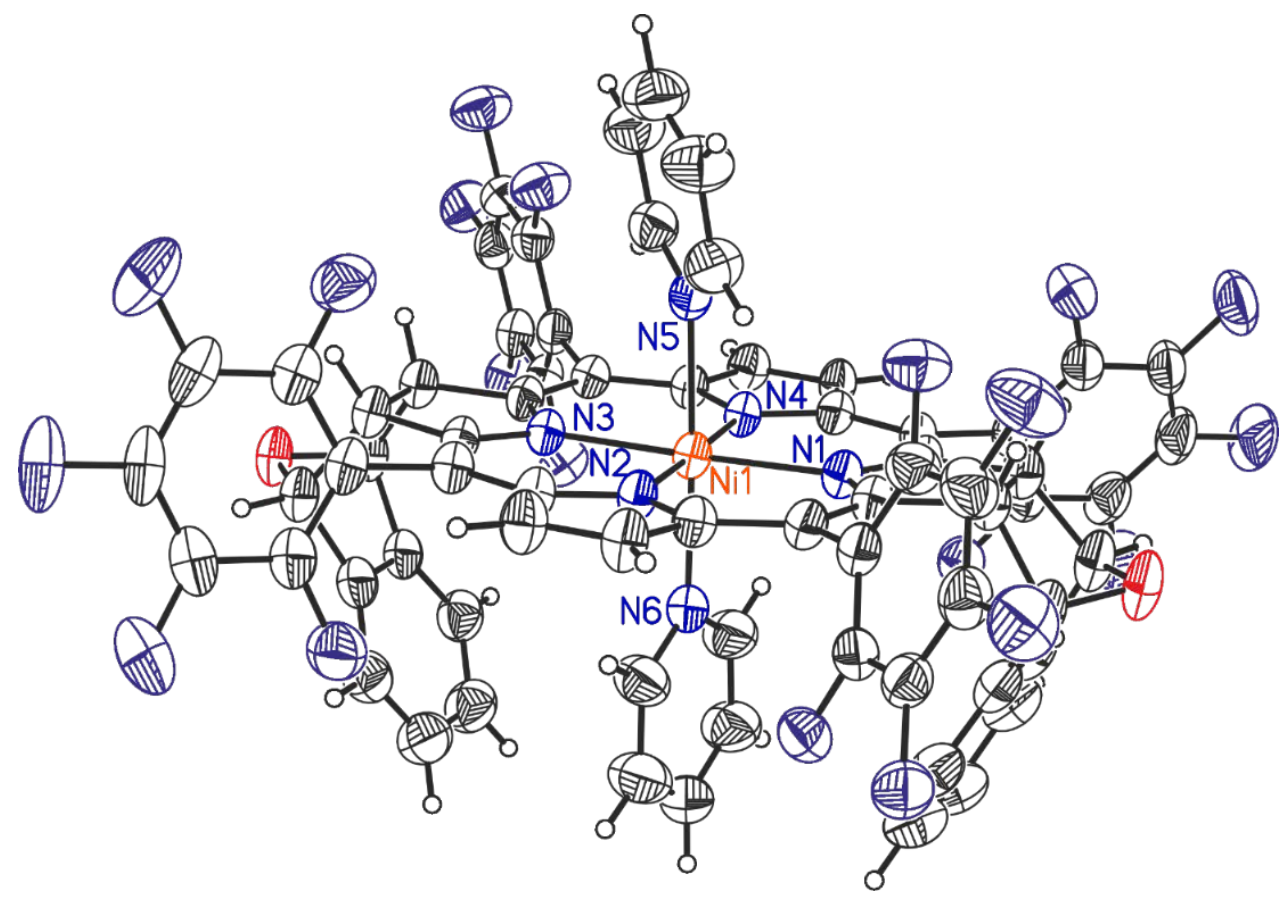

Fig. S37 Crystal structure of $\mathbf{3} \cdot \mathbf{P y} \mathbf{y}_{2}$ with labeling and displacement ellipsoids drawn at the $50 \%$ probability level. Color codes: Ni: orange, N: blue, F: violet, O: red.

Table S23 Bond lengths $[\AA]$ and angles $\left[{ }^{\circ}\right]$ for $\mathbf{3} \cdot \mathbf{P y}$.

$\begin{array}{cc}\mathrm{Ni}(1)-\mathrm{N}(4) & 2.029(3) \\ \mathrm{Ni}(1)-\mathrm{N}(2) & 2.038(3) \\ \mathrm{Ni}(1)-\mathrm{N}(1) & 2.114(2) \\ & \\ \mathrm{N}(4)-\mathrm{Ni}(1)-\mathrm{N}(2) & 178.20(11) \\ \mathrm{N}(4)-\mathrm{Ni}(1)-\mathrm{N}(1) & 89.59(10) \\ \mathrm{N}(2)-\mathrm{Ni}(1)-\mathrm{N}(1) & 90.26(10) \\ \mathrm{N}(4)-\mathrm{Ni}(1)-\mathrm{N}(3) & 90.01(10) \\ \mathrm{N}(2)-\mathrm{Ni}(1)-\mathrm{N}(3) & 90.09(10) \\ \mathrm{N}(1)-\mathrm{Ni}(1)-\mathrm{N}(3) & 178.31(11) \\ \mathrm{N}(4)-\mathrm{Ni}(1)-\mathrm{N}(6) & 90.79(11) \\ \mathrm{N}(2)-\mathrm{Ni}(1)-\mathrm{N}(6) & 91.00(11)\end{array}$

$\begin{array}{cc}\mathrm{Ni}(1)-\mathrm{N}(3) & 2.126(2) \\ \mathrm{Ni}(1)-\mathrm{N}(6) & 2.182(3) \\ \mathrm{Ni}(1)-\mathrm{N}(5) & 2.230(3) \\ & \\ \mathrm{N}(1)-\mathrm{Ni}(1)-\mathrm{N}(6) & 90.40(10) \\ \mathrm{N}(3)-\mathrm{Ni}(1)-\mathrm{N}(6) & 91.25(10) \\ \mathrm{N}(4)-\mathrm{Ni}(1)-\mathrm{N}(5) & 91.21(11) \\ \mathrm{N}(2)-\mathrm{Ni}(1)-\mathrm{N}(5) & 87.00(11) \\ \mathrm{N}(1)-\mathrm{Ni}(1)-\mathrm{N}(5) & 91.07(10) \\ \mathrm{N}(3)-\mathrm{Ni}(1)-\mathrm{N}(5) & 87.29(10) \\ \mathrm{N}(6)-\mathrm{Ni}(1)-\mathrm{N}(5) & 177.53(11)\end{array}$




\section{Photochromism}

\section{V.1 Photostationary States (PSS)}

The isomerization of RPs can also be observed with NMR spectroscopy. By integration of appropriate signals in ${ }^{1} \mathrm{H}$ NMR spectrum the cis-trans-ratio can be determined (Fig. S38-S39). For RP 10b, 12a and 12b no PSS could be determined due to overlapping signals. For sharper signals TFA-d ( $20 \mu \mathrm{L})$ was added after irradiation.
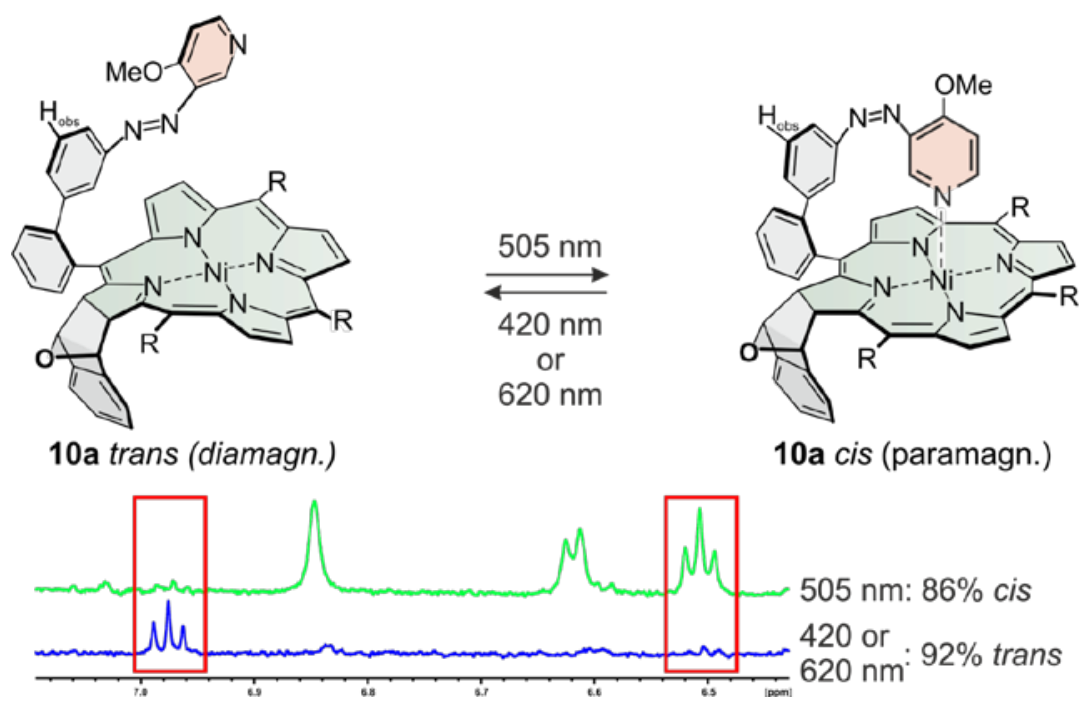

Fig. S38 Photo stationary states at 505 and 420 or $620 \mathrm{~nm}$ of RP 10a observed by ${ }^{1} \mathrm{H}$ NMR spectroscopy in acetone- $\mathrm{d}_{6}\left(\mathrm{R}=\mathrm{C}_{6} \mathrm{~F}_{5}\right)$. The sharp triplet belongs to $\mathrm{H}_{\text {obs }}$ of the trans and cis isomer.

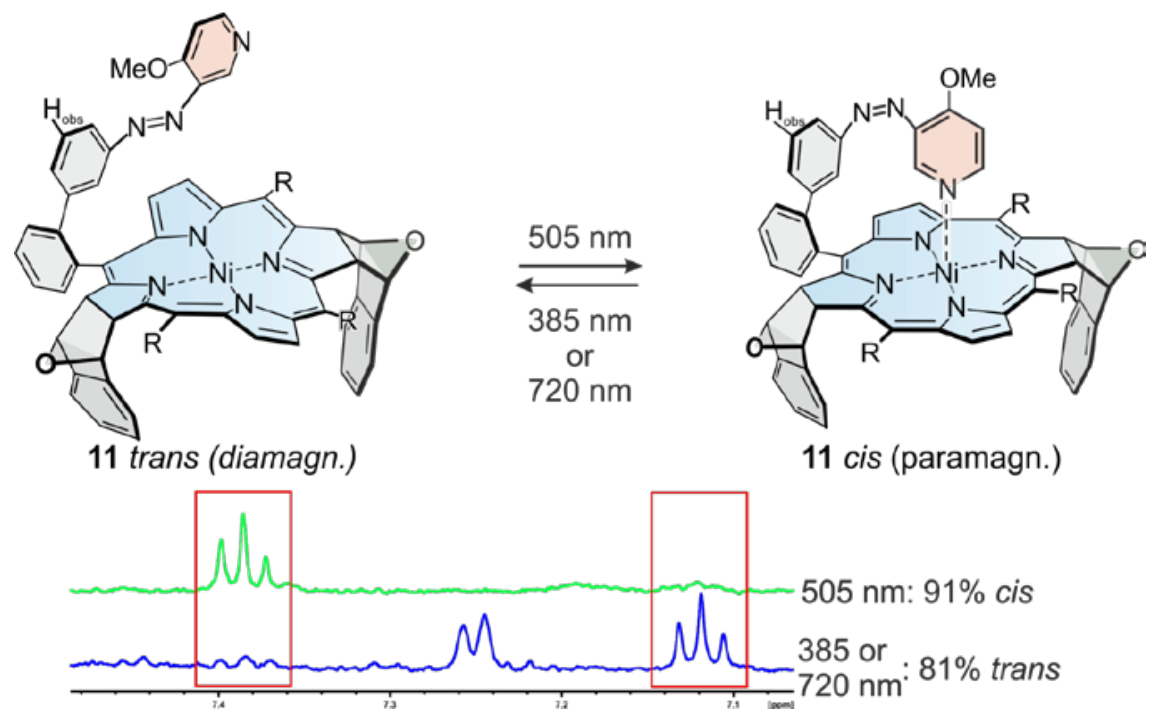

Fig. S39 Photo stationary states at 505 and 385 or $720 \mathrm{~nm}$ of RP 11 observed by ${ }^{1} \mathrm{H}$ NMR spectroscopy in acetone- $\mathrm{d}_{6}\left(\mathrm{R}=\mathrm{C}_{6} \mathrm{~F}_{5}\right)$. The sharp triplet belongs to $\mathrm{H}_{\mathrm{obs}}$ of the trans and cis isomer. 


\section{V.2 Switching Efficiencies - Percentage of the Paramagnetic Species}

To calculate the percentage of the 4- and 5-coordinate species of 10a, 10b, 11, 12a and 12b after irradiation with blue, green or red light the extinction coefficients of all record players were determined. Because of incomplete switching to the trans or cis isomer trifluoracetic acid (TFA) or piperidine was added to calculate the extinction coefficient of the fully diamagnetic (4-coordinate species) and paramagnetic (5- and 6-coordinate species) bands (Fig. S40-S53). We assumed that the extinction coefficients of the 5- and 6-coordinate species are equal.
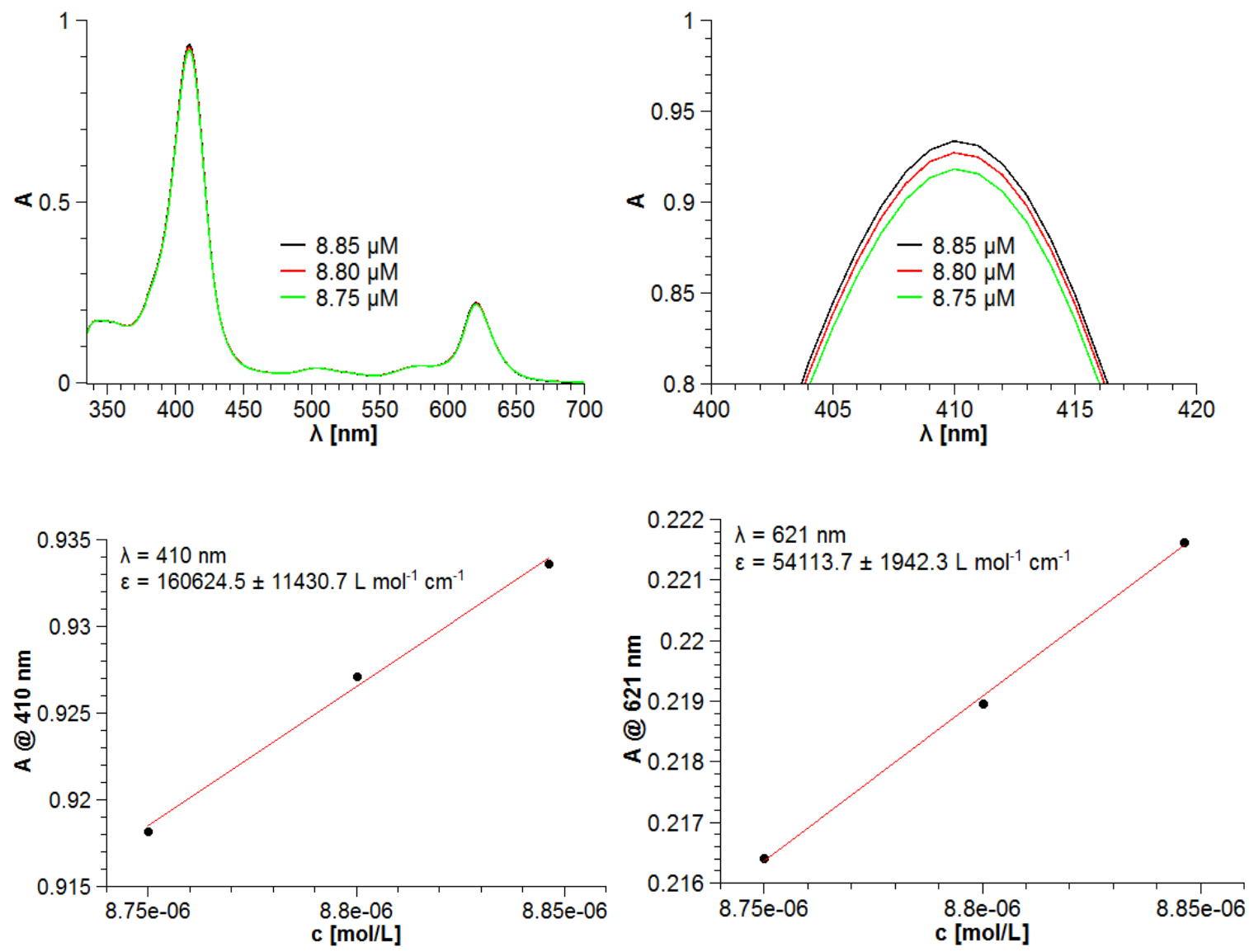

Fig. S40 UV-Vis spectra of 10a at different concentrations in acetone $+11 \%$ TFA (top) and extinction coefficients of the bands 410 and $621 \mathrm{~nm}$. 

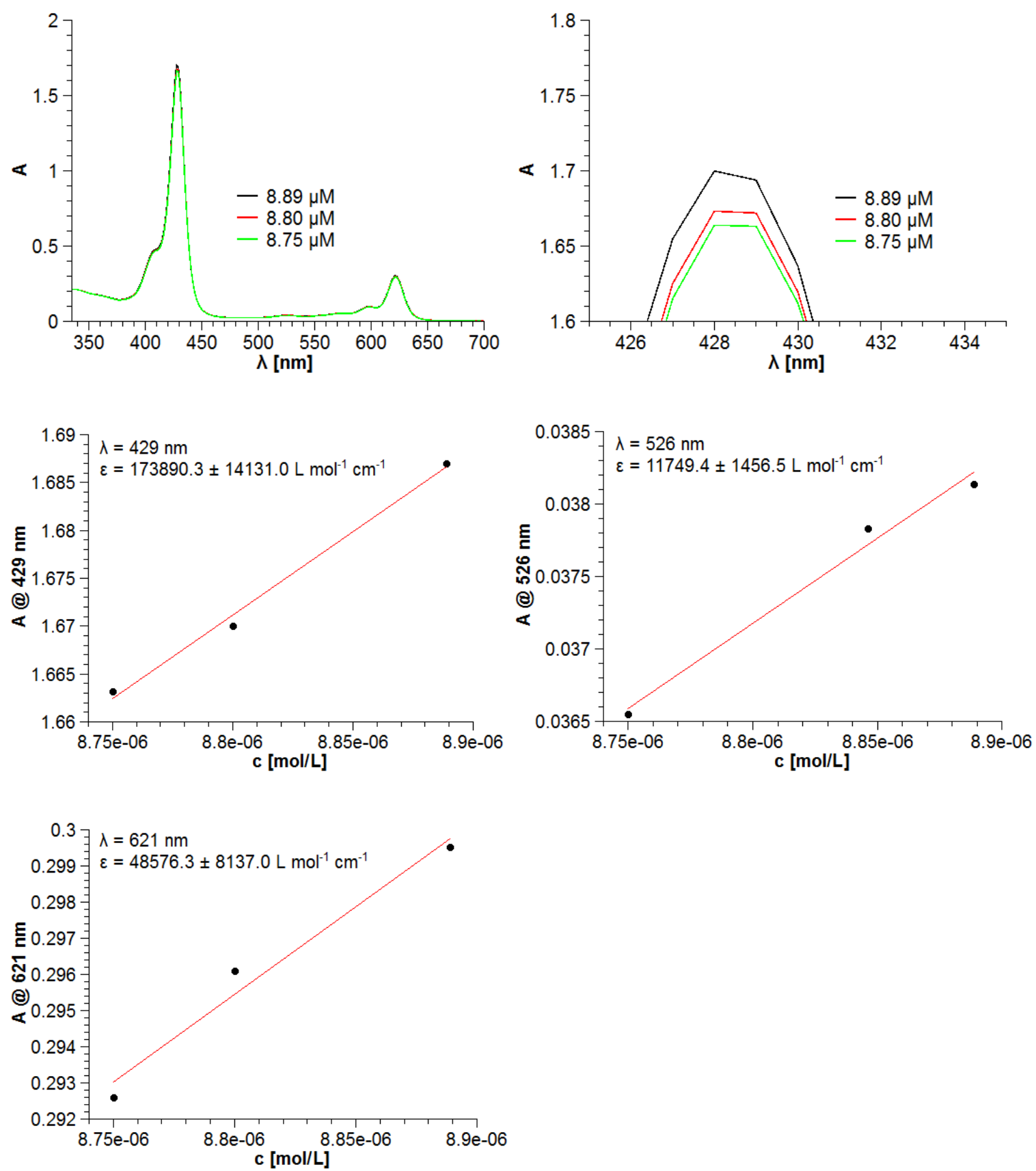

Fig. S41 UV-Vis spectra of 10a at different concentrations in acetone $+11 \%$ piperidine (top) and extinction coefficients of the bands 429, 526, $621 \mathrm{~nm}$. 

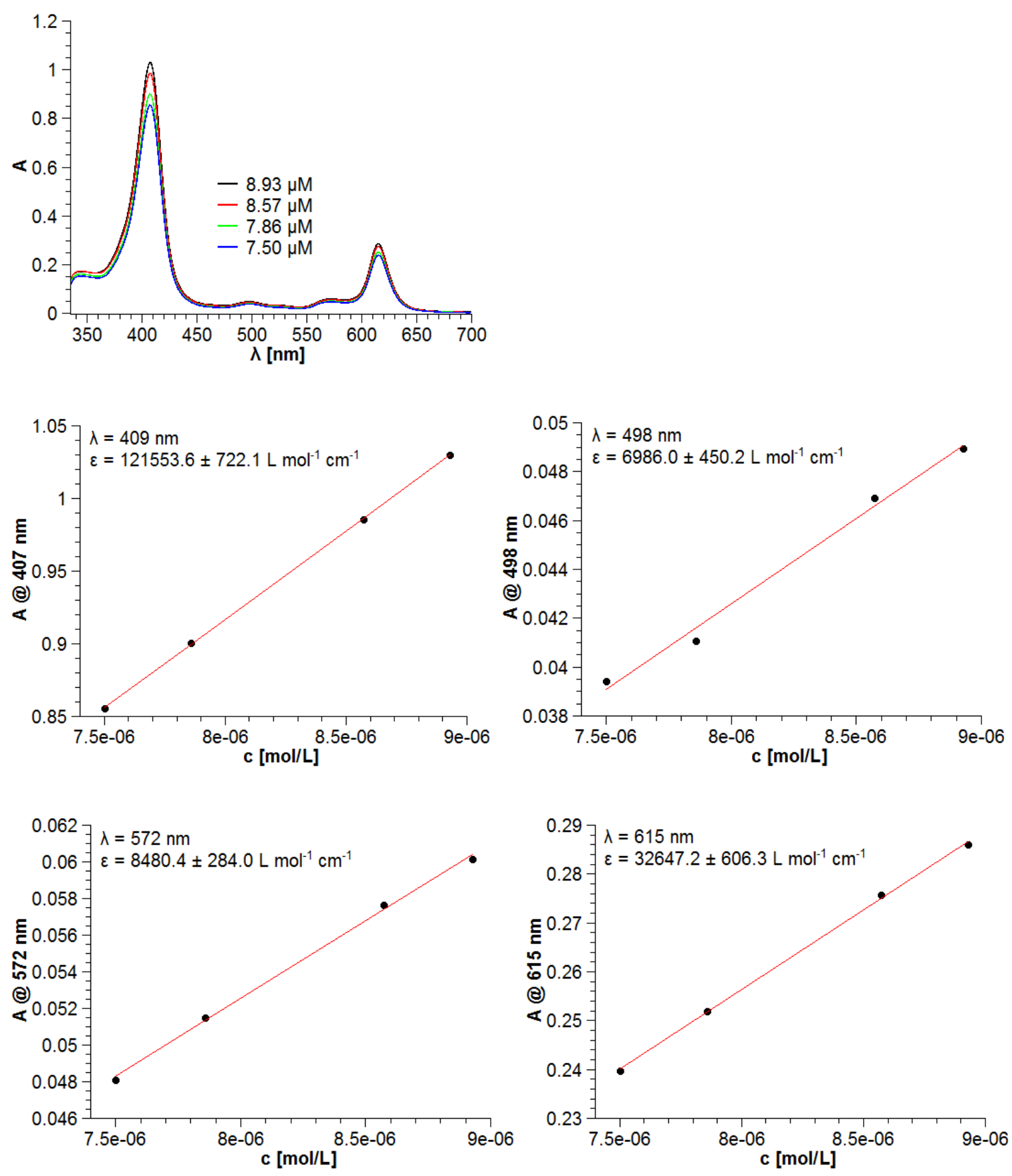

Fig. S42 UV-Vis spectra of $\mathbf{1 0 b}$ at different concentrations in acetone $+11 \%$ TFA (top) and extinction coefficients of the bands 409, 498, 572 and $615 \mathrm{~nm}$. 

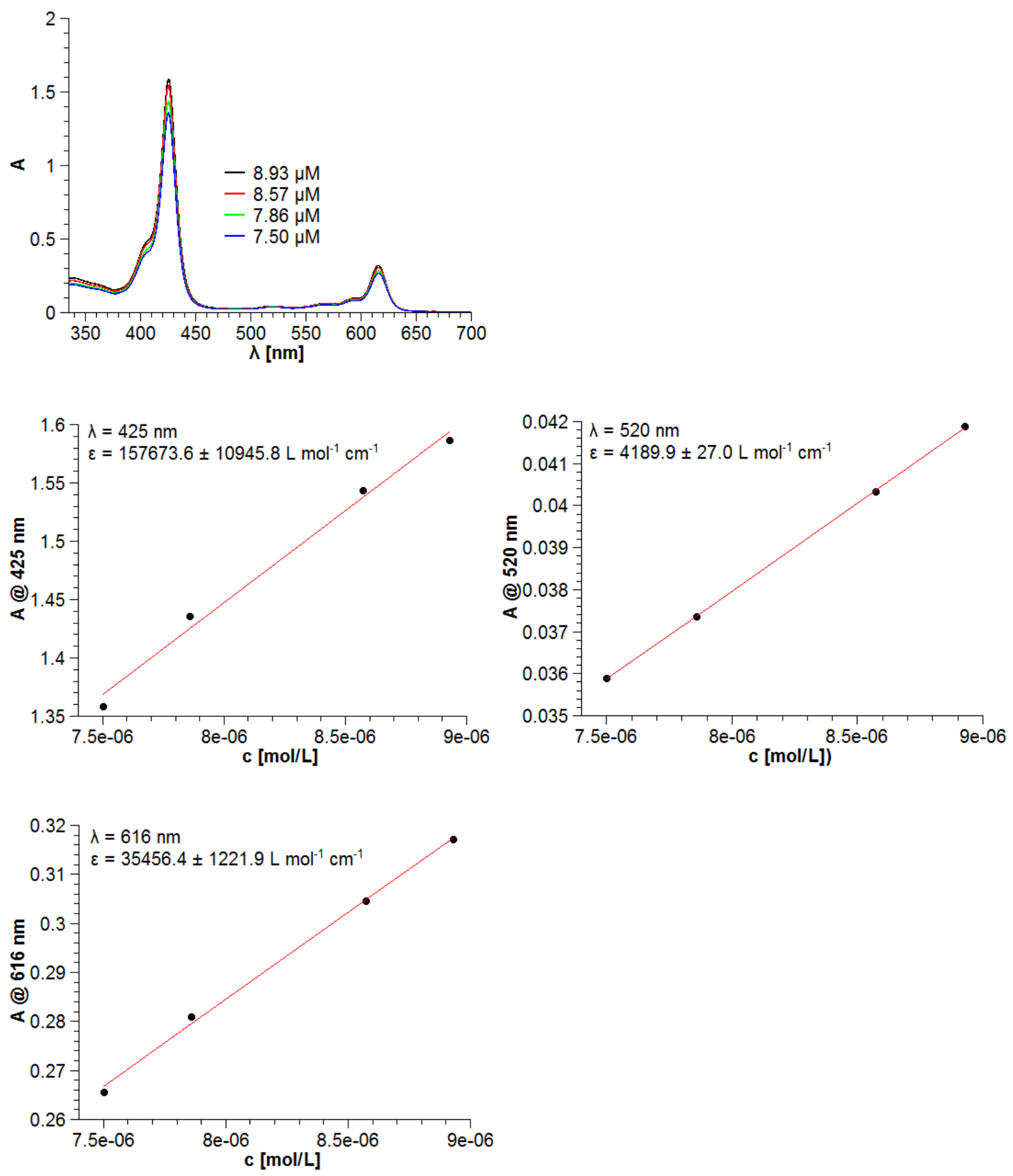

Fig. S43 UV-Vis spectra of $\mathbf{1 0 b}$ at different concentrations in acetone $+11 \%$ piperidine (top) and extinction coefficients of the bands 425, 520, $616 \mathrm{~nm}$. 

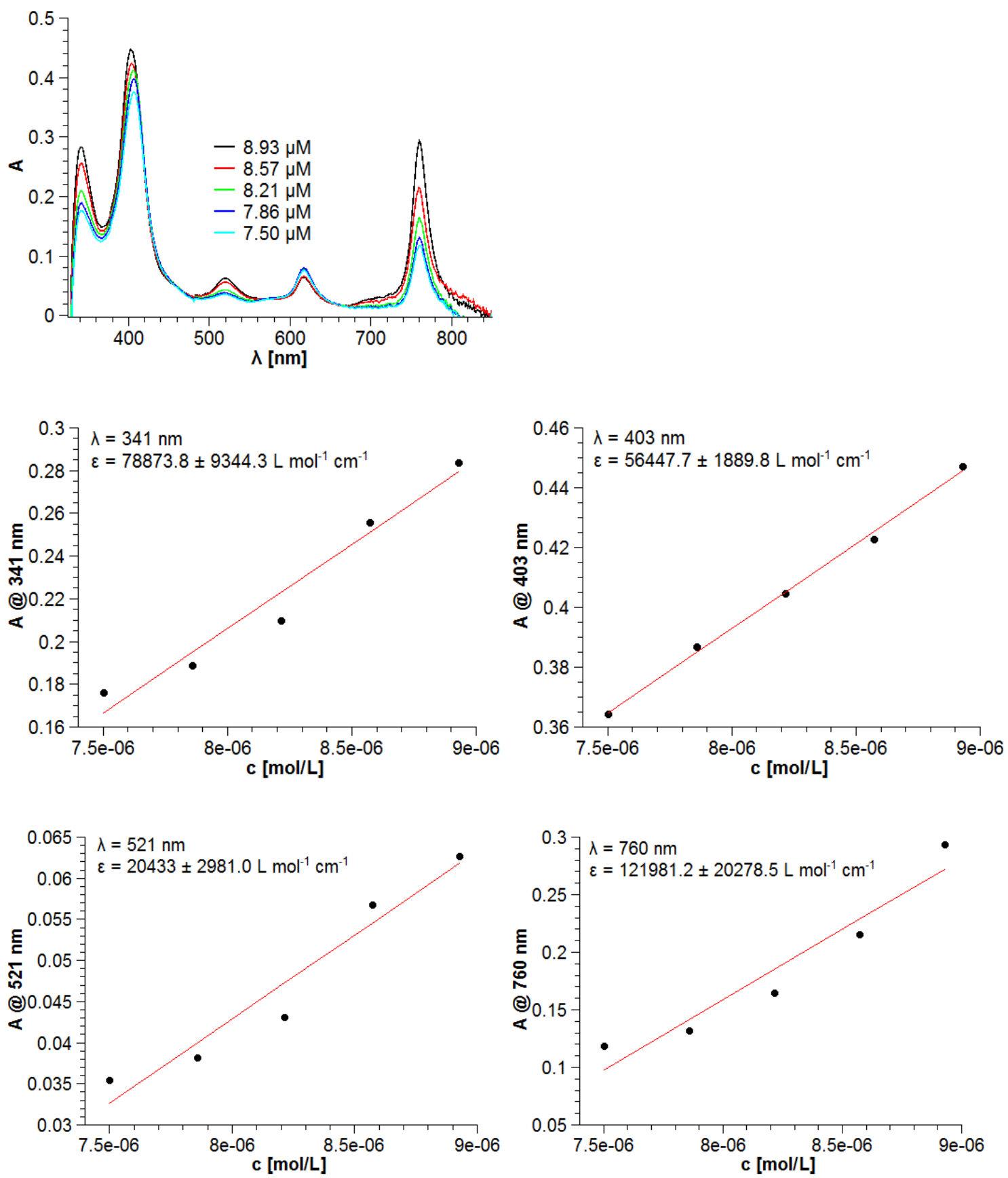

Fig. S44 UV-Vis spectra of $\mathbf{1 1}$ at different concentrations in acetone + 11\% TFA (top) and extinction coefficients of the bands 341, 403, 521 and $760 \mathrm{~nm}$. 

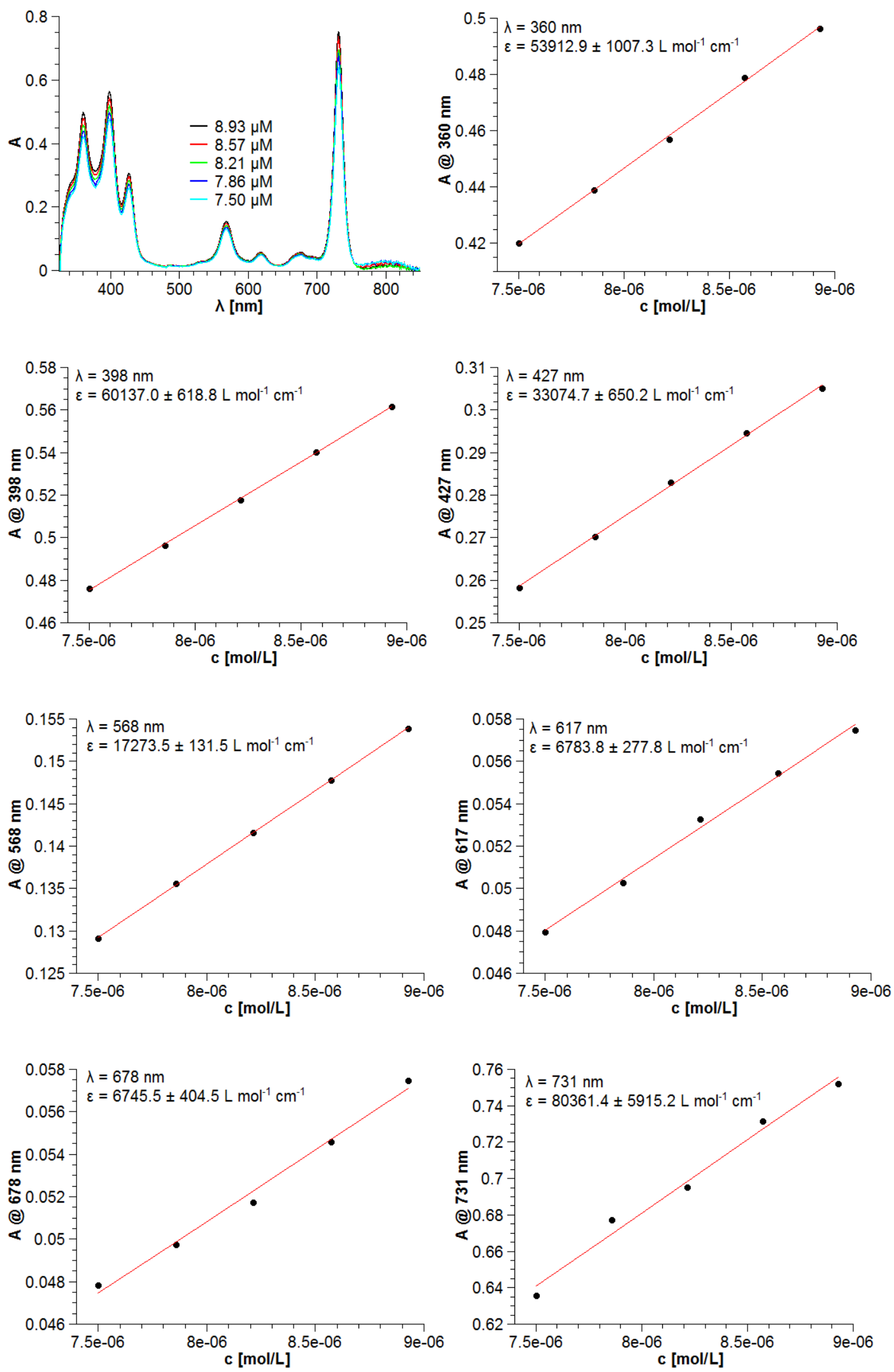

Fig. S45 UV-Vis spectra of $\mathbf{1 1}$ at different concentrations in acetone $+11 \%$ piperidine (top) and extinction coefficients of the bands 360, 398, 427, 568, 617, 678 and $731 \mathrm{~nm}$. 

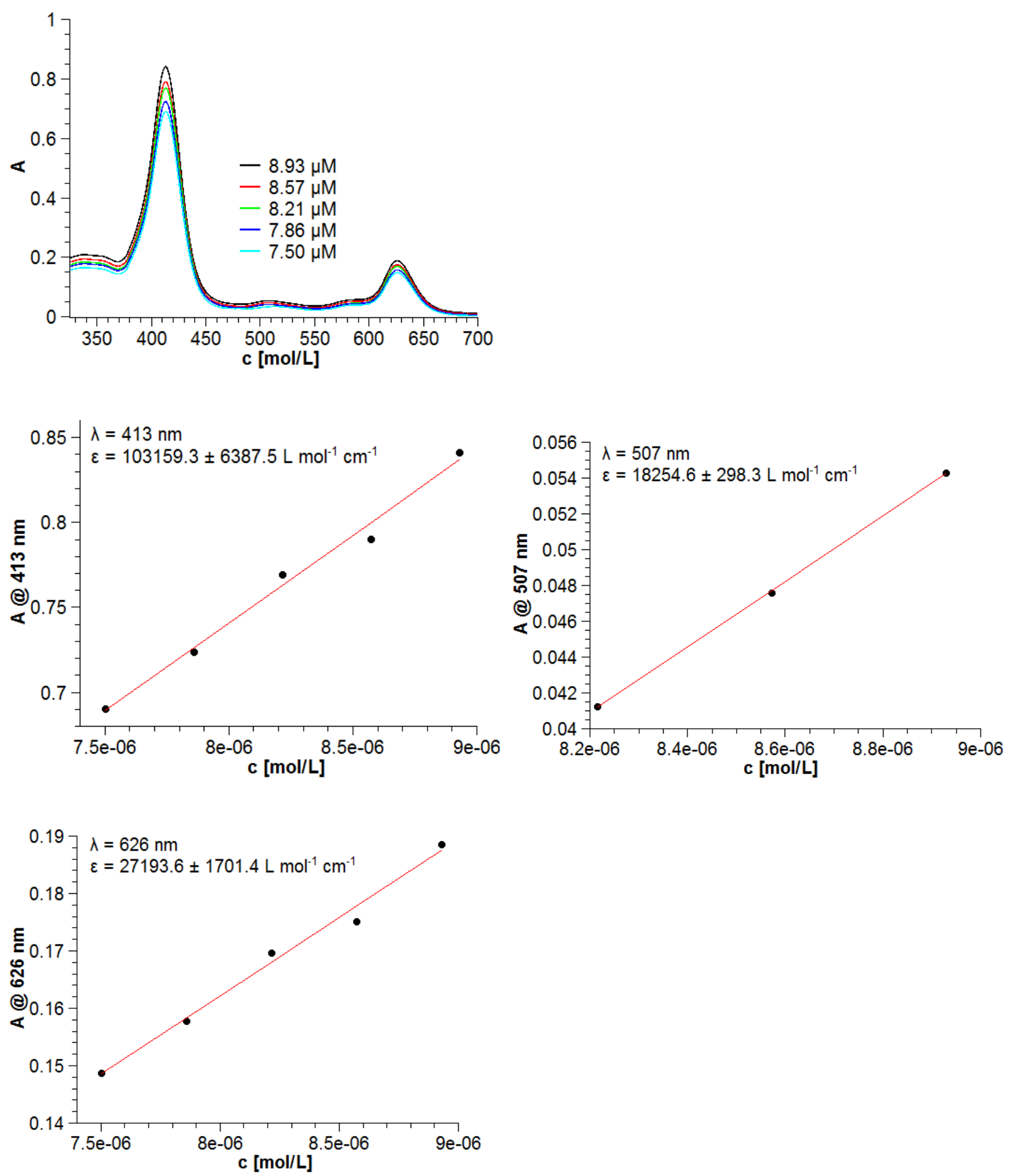

Fig. S46 UV-Vis spectra of 12a at different concentrations in water + 11\% TFA (top) and extinction coefficients of the bands 413, 507, $626 \mathrm{~nm}$. 

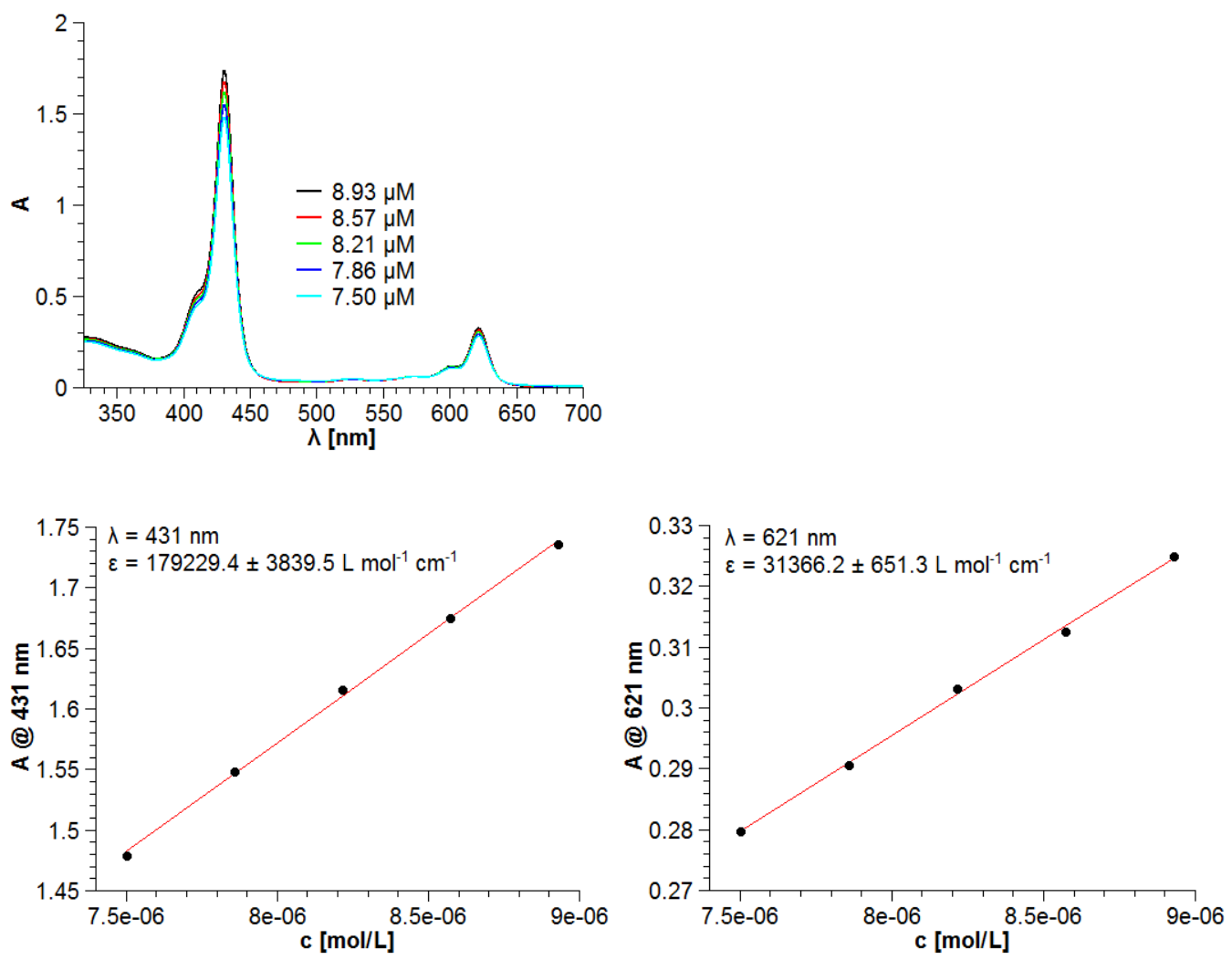

Fig. S47 UV-Vis spectra of 12a at different concentrations in water $+11 \%$ piperidine (top) and extinction coefficients of the bands 431 and $621 \mathrm{~nm}$. 

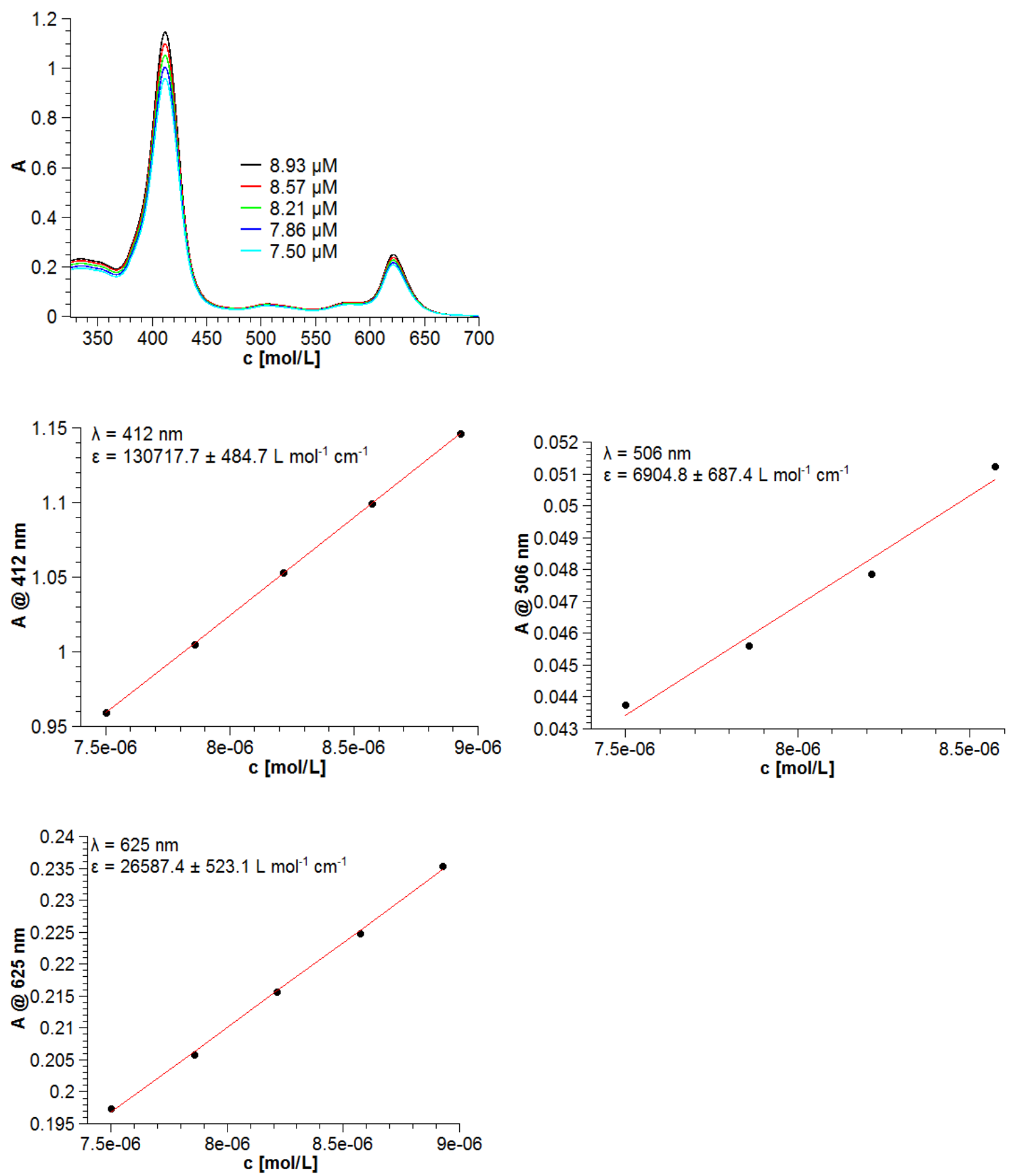

Fig. S48 UV-Vis spectra of 12a at different concentrations in methanol + 11\% TFA (top) and extinction coefficients of the bands 412, 506 and $625 \mathrm{~nm}$. 

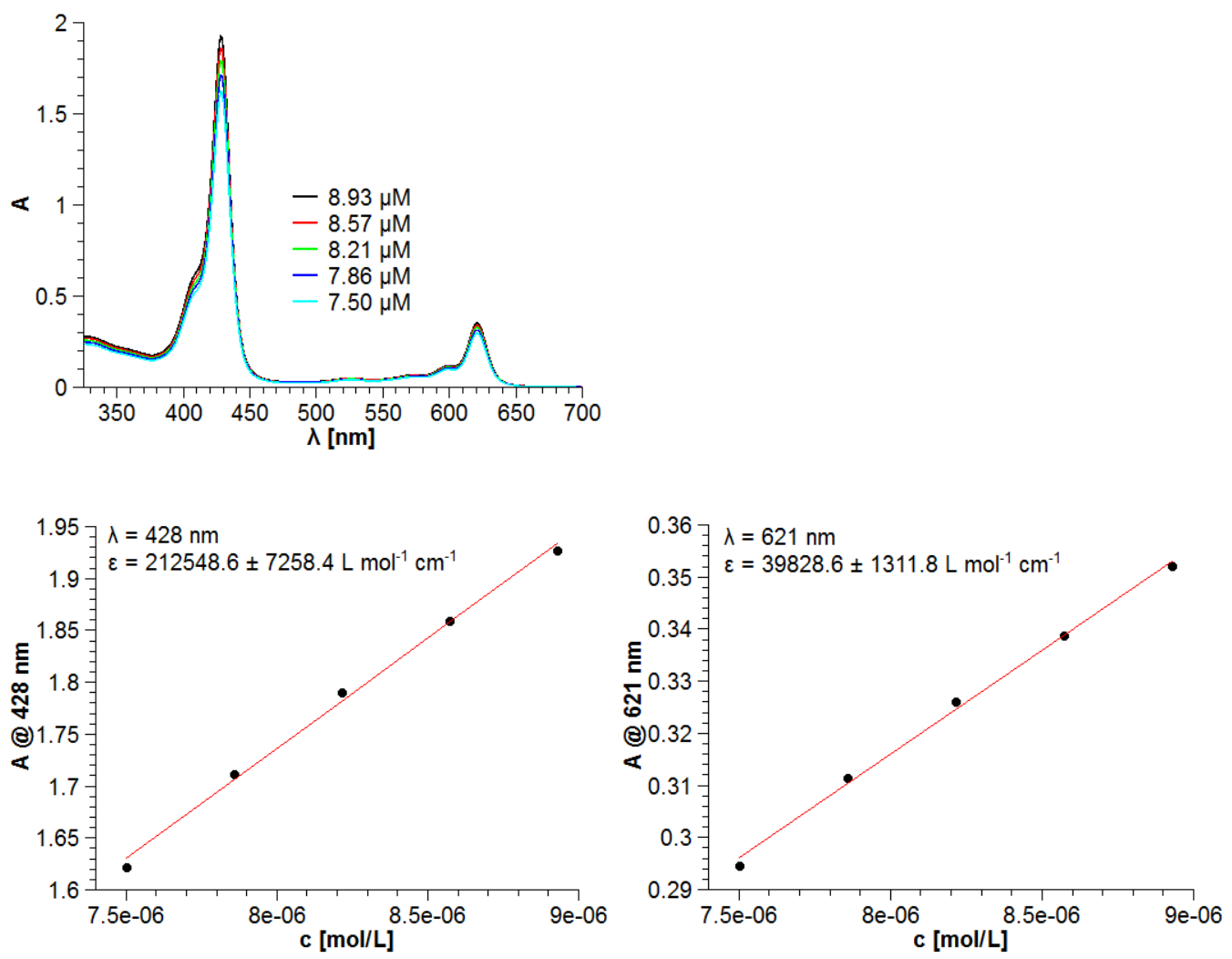

Fig. S49 UV-Vis spectra of 12a at different concentrations in methanol $+11 \%$ piperidine (top) and extinction coefficients of the bands 428 and $621 \mathrm{~nm}$. 

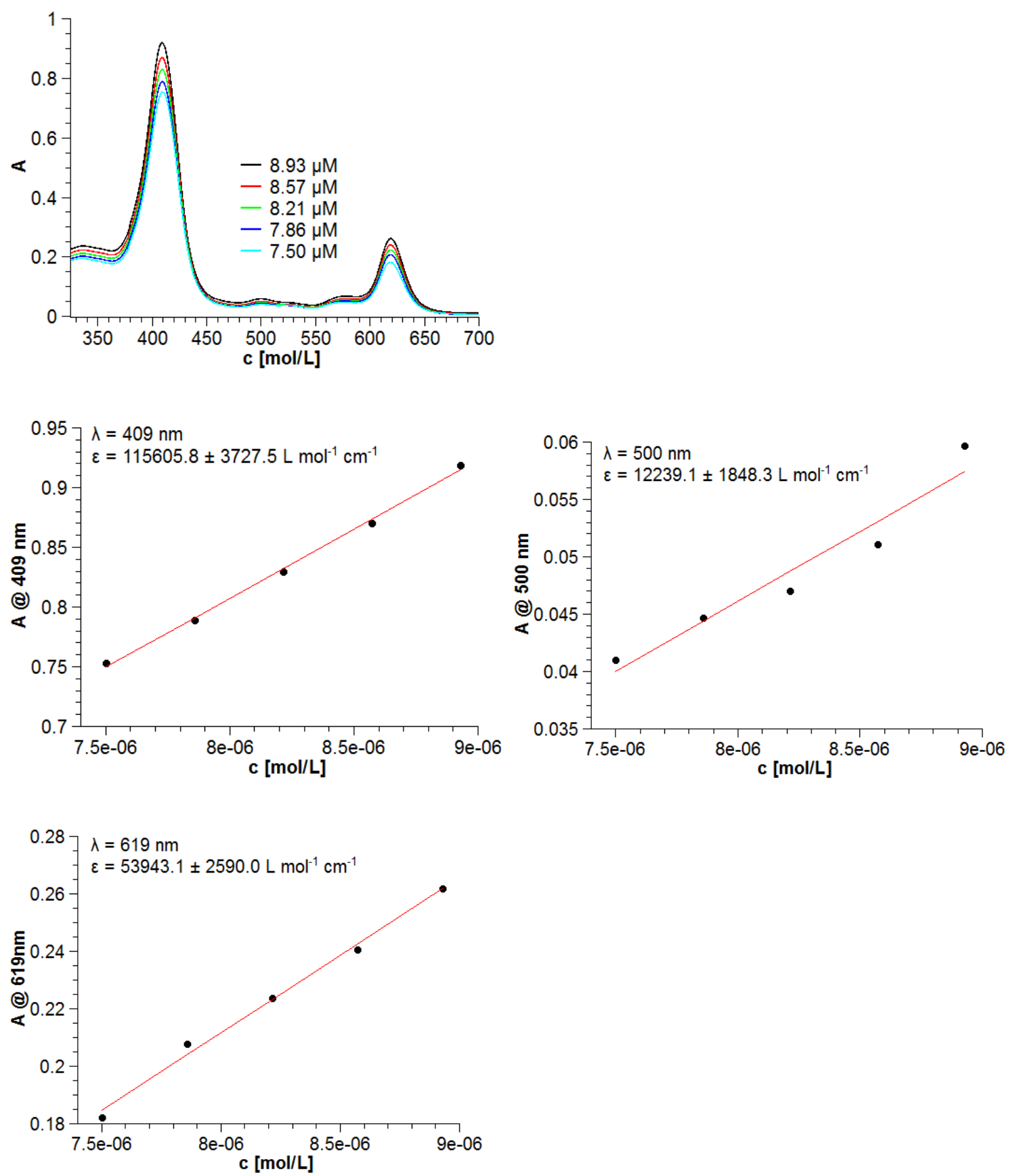

Fig. S50 UV-Vis spectra of $\mathbf{1 2 b}$ at different concentrations in water $+11 \%$ TFA (top) and extinction coefficients of the bands 409, 500, $619 \mathrm{~nm}$. 

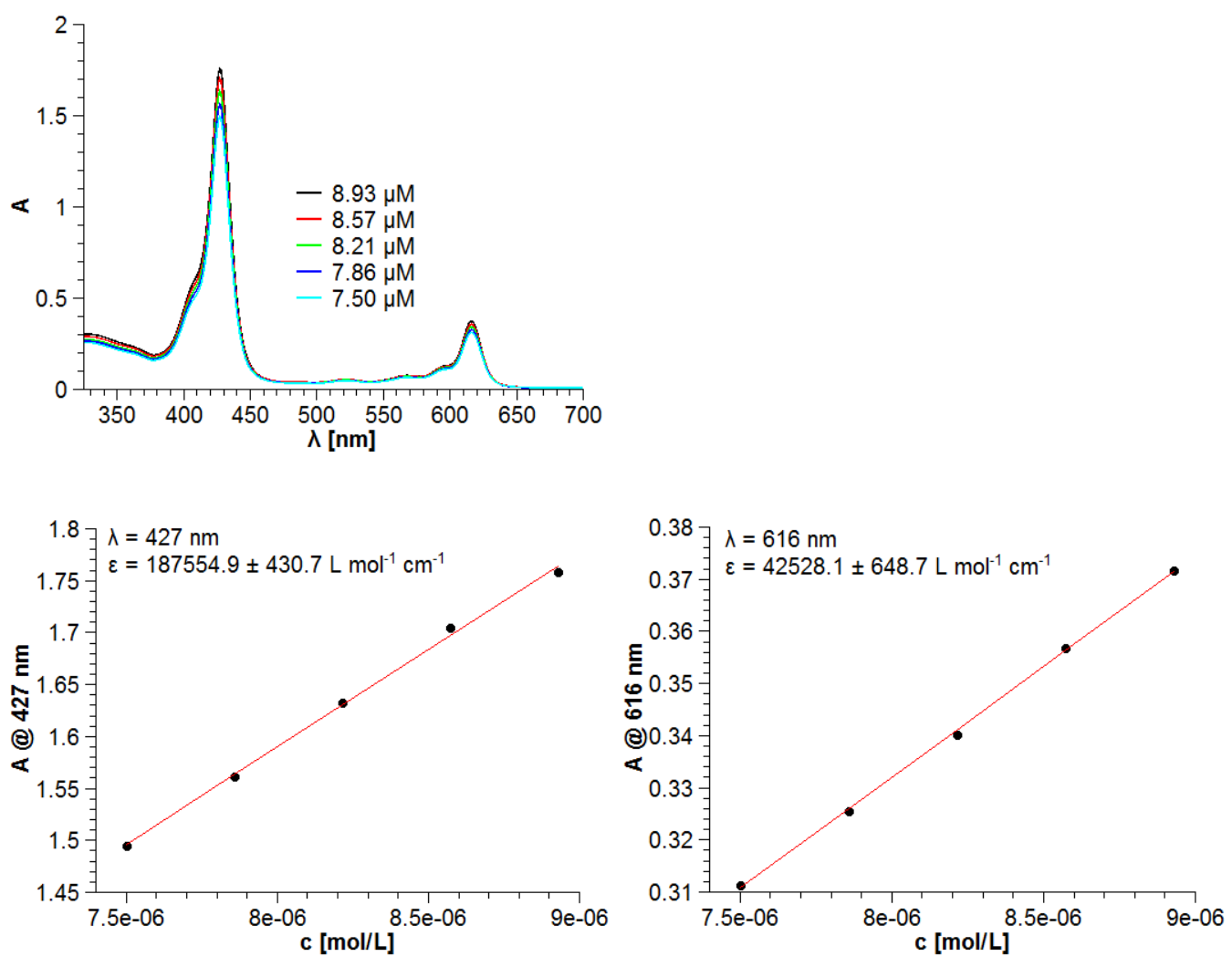

Fig. S51 UV-Vis spectra of $\mathbf{1 2 b}$ at different concentrations in water $+11 \%$ piperidine (top) and extinction coefficients of the bands 427and $616 \mathrm{~nm}$. 

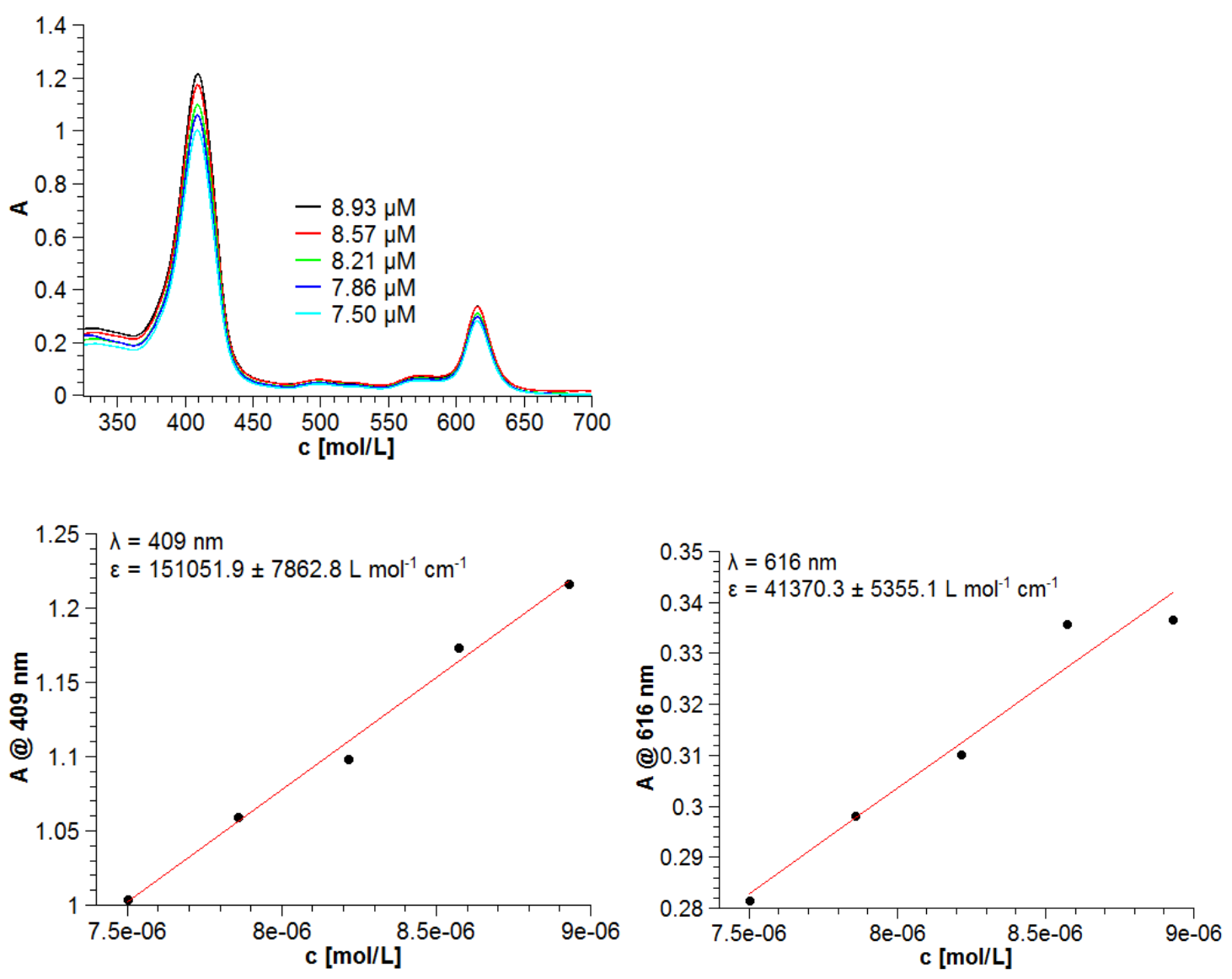

Fig. S52 UV-Vis spectra of $\mathbf{1 2 b}$ at different concentrations in methanol + 11\% TFA (top) and extinction coefficients of the bands 409 and $616 \mathrm{~nm}$. 

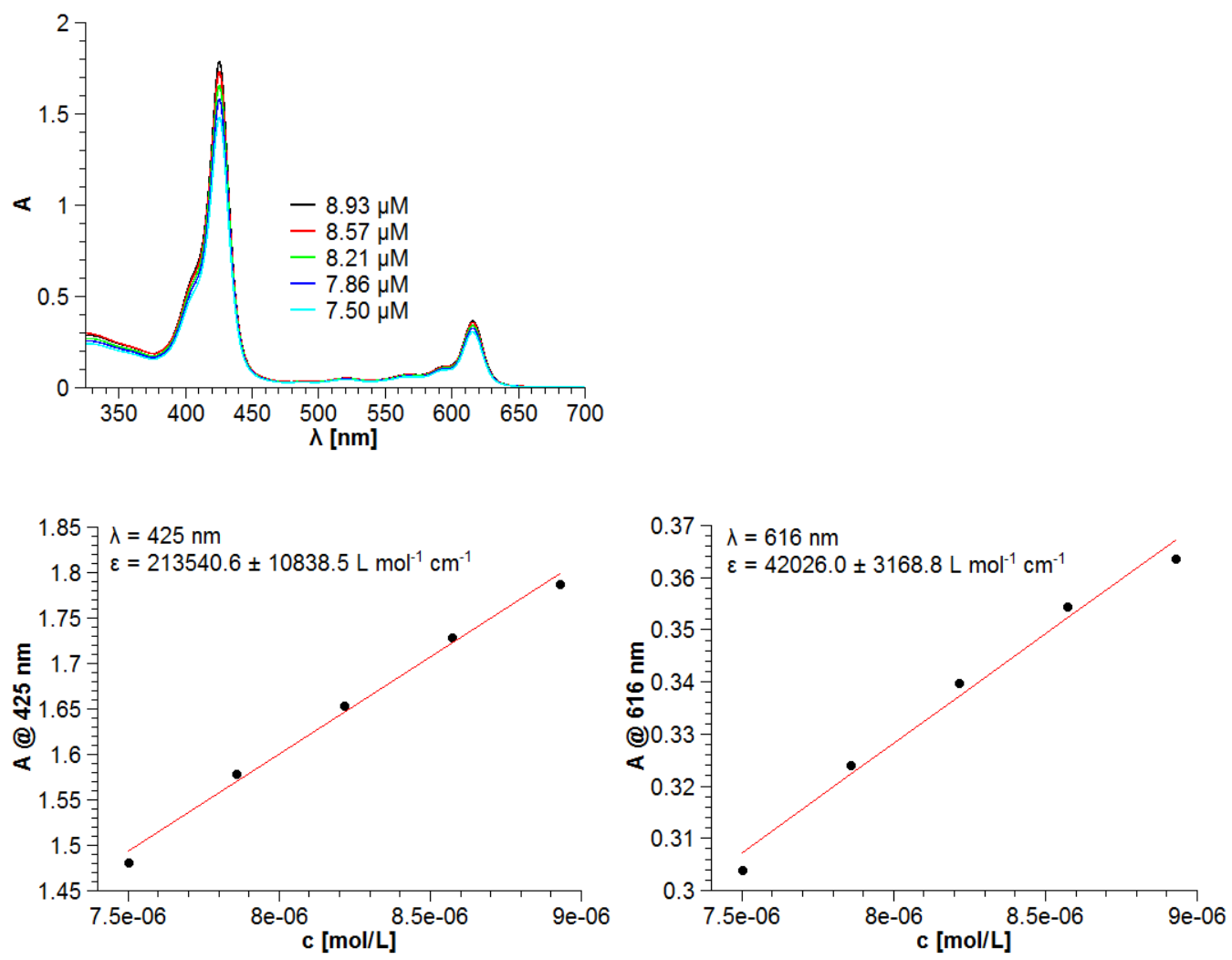

Fig. S53 UV-Vis spectra of $\mathbf{1 2 b}$ at different concentrations in methanol $+11 \%$ piperidine (top) and extinction coefficients of the bands 425 and $616 \mathrm{~nm}$. 
For the calculation of the paramagnetic percentage after switching with green light $(505 \mathrm{~nm})$ the extinction coefficient of a paramagnetic band is needed:

$$
\begin{aligned}
& \varepsilon_{429 \mathrm{~nm}, \text { 10a, acetone }}=173890.3 \mathrm{Lmol}^{-1} \mathrm{~cm}^{-1}(\text { Fig. S41) } \\
& \varepsilon_{425 \mathrm{~nm}, \mathbf{1 0 b} \text {, acetone }}=157673.6 \mathrm{Lmol}^{-1} \mathrm{~cm}^{-1}(\text { Fig. S43) } \\
& \varepsilon_{731 \mathrm{~nm}, 11 \text {, acetone }}=80361.4 \mathrm{Lmol}^{-1} \mathrm{~cm}^{-1} \text { (Fig. S45) } \\
& \varepsilon_{431 \mathrm{~nm}, 12 \mathrm{a}, \text { water }}=179229.4 \mathrm{Lmol}^{-1} \mathrm{~cm}^{-1} \text { (Fig. S47) } \\
& \varepsilon_{428 \mathrm{~nm}, 12 \mathrm{a}, \mathrm{MeOH}}=212548.6 \mathrm{Lmol}^{-1} \mathrm{~cm}^{-1} \text { (Fig. S49) } \\
& \varepsilon_{431 \mathrm{~nm}, 12 \mathrm{~b} \text {, water }}=187554.9 \mathrm{Lmol}^{-1} \mathrm{~cm}^{-1} \text { (Fig. S51) } \\
& \varepsilon_{428 \mathrm{~nm}, 12 \mathbf{b}, \mathrm{MeOH}}=212548.6 \mathrm{Lmol}^{-1} \mathrm{~cm}^{-1} \text { (Fig. S53) }
\end{aligned}
$$

$100 \%$ switching efficiency at a known concentration in a 1cm cuvette will lead to:

$$
\begin{array}{ll}
\text { 10a }(c=8.75 \mu \mathrm{M}): & A_{\text {para max }}=\varepsilon_{429 \mathrm{~nm}} \cdot \mathrm{c} \cdot \mathrm{d}=1.52154 \text { (acetone) } \\
\text { 10b }(\mathrm{c}=7.50 \mu \mathrm{M}): & \mathrm{A}_{\text {para } \max }=\varepsilon_{425 \mathrm{~nm}} \cdot \mathrm{c} \cdot \mathrm{d}=1.18255 \text { (acetone) } \\
\text { 11 }(\mathrm{c}=7.50 \mu \mathrm{M}): & \mathrm{A}_{\text {para } \max }=\varepsilon_{731 \mathrm{~nm}} \cdot \mathrm{c} \cdot \mathrm{d}=0.60271 \text { (acetone) } \\
\text { 12a }(\mathrm{c}=8.93 \mu \mathrm{M}): & \mathrm{A}_{\text {para } \max }=\varepsilon_{431 \mathrm{~nm}} \cdot \mathrm{c} \cdot \mathrm{d}=1.60026 \text { (water) } \\
\text { 12a }(\mathrm{c}=8.93 \mu \mathrm{M}): & \mathrm{A}_{\text {para } \max }=\varepsilon_{431 \mathrm{~nm}} \cdot \mathrm{c} \cdot \mathrm{d}=1.89776 \text { (methanol) } \\
\text { 12b }(\mathrm{c}=8.93 \mu \mathrm{M}): & \mathrm{A}_{\text {para } \max }=\varepsilon_{431 \mathrm{~nm}} \cdot \mathrm{c} \cdot \mathrm{d}=1.67460 \text { (water) } \\
\text { 12b }(\mathrm{c}=8.93 \mu \mathrm{M}): & \mathrm{A}_{\text {para } \max }=\varepsilon_{431 \mathrm{~nm}} \cdot \mathrm{c} \cdot \mathrm{d}=1.90661 \text { (methanol) }
\end{array}
$$

The observed absorption ( $\mathrm{A}_{\mathrm{obs}}$ ) after incomplete switching with green light $(505 \mathrm{~nm})$ is the sum of the absorption of the diamagnetic trans isomer $\left(\mathrm{A}_{\text {dia }}\right)$ and the paramagnetic cis isomer $\left(\mathrm{A}_{\text {para }}\right) \mathrm{x}$ is the percentage of the diamagnetic trans isomer (Fig. S54-S67).

$$
\begin{aligned}
& A_{\text {obs }}=A_{\text {dia }}+A_{\text {para }} \\
& A_{\text {dia }}=A_{\text {dia max }} \cdot x \\
& A_{\text {para }}=A_{\text {para max }} \cdot(1-x) \\
& A_{\text {obs }}=A_{\text {dia max }} \cdot x+A_{\text {para max }} \cdot(1-x) \\
& x=\left(A_{\text {obs }}-A_{\text {para max }}\right) /\left(A_{\text {dias max }}-A_{\text {para max }}\right)
\end{aligned}
$$




\section{Chlorin RP 10a in Acetone}

After irradiation with $505 \mathrm{~nm}$ at $\lambda=421 \mathrm{~nm}$ :

$\mathrm{A}_{\text {obs }}=1.39, \mathrm{~A}_{\text {para } \max }=1.52, \mathrm{~A}_{\text {dia } \max }=0.575$

$\mathrm{x}=(1.39-1.52) /(0.575-1.52)=0.14$

$14 \%$ dia- and $86 \%$ paramagnetic species
After irradiation with $420 \mathrm{~nm}$ at $\lambda=412 \mathrm{~nm}$

8\% paramagnetic species left

After irradiation with $620 \mathrm{~nm}$ at $\lambda=414 \mathrm{~nm}$

$13 \%$ paramagnetic species left

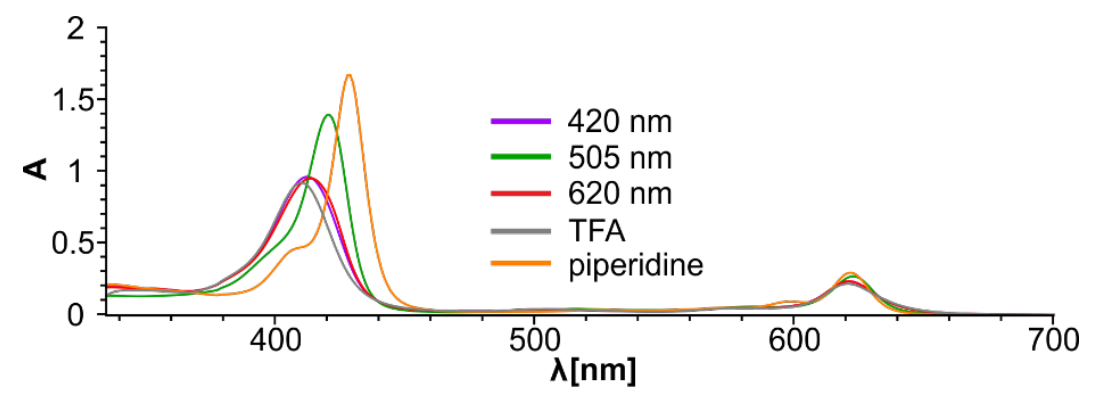

Fig. S54 UV-Vis spectra of 10a in acetone $(8.75 \mu \mathrm{M})$ after irradiation with blue $(420 \mathrm{~nm})$, green (505 nm) and red (620 nm) light and after addition of piperidine and TFA. The amount of paramagnetic species after switching with green light $(505 \mathrm{~nm})$ is $86 \%$.

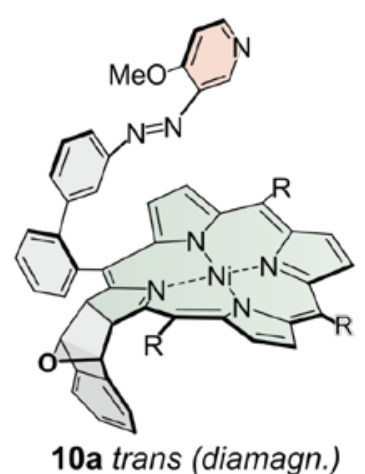

10a trans (diamagn.)

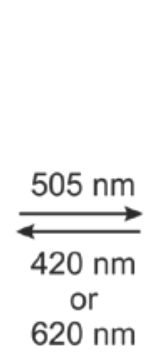

switching

efficiency

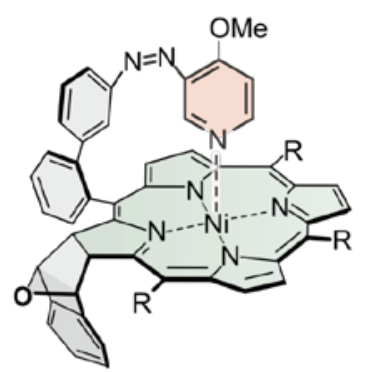

10 a cis (paramagn.)

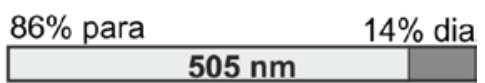

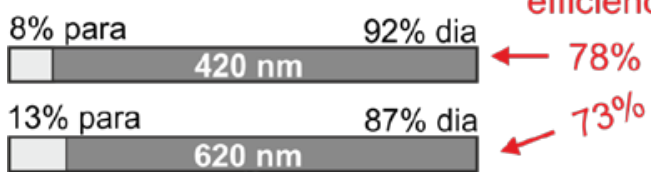

Fig. S55 Percentage of paramagnetic nickel ions after irradiation of 10a $(8.75 \mu \mathrm{M})$ in acetone at $25^{\circ} \mathrm{C}$ with 420, 505 and $620 \mathrm{~nm}$ light $\left(\mathrm{R}=\mathrm{C}_{6} \mathrm{~F}_{5}\right)$. 


\section{Chlorin RP 10b in Acetone}

After irradiation with $505 \mathrm{~nm}$ at $\lambda=417 \mathrm{~nm}$ :

$\mathrm{A}_{\text {obs }}=1.12, \mathrm{~A}_{\text {para } \max }=1.18, \mathrm{~A}_{\text {dia } \max }=0.540$

$\mathrm{x}=(1.12-1.18) /(0.540-1.18)=0.09$

9\% dia- and 91\% paramagnetic species
After irradiation with $420 \mathrm{~nm}$ at $\lambda=409 \mathrm{~nm}$

$<5 \%$ paramagnetic species left

After irradiation with $620 \mathrm{~nm}$ at $\lambda=410 \mathrm{~nm}$

$<5 \%$ paramagnetic species left

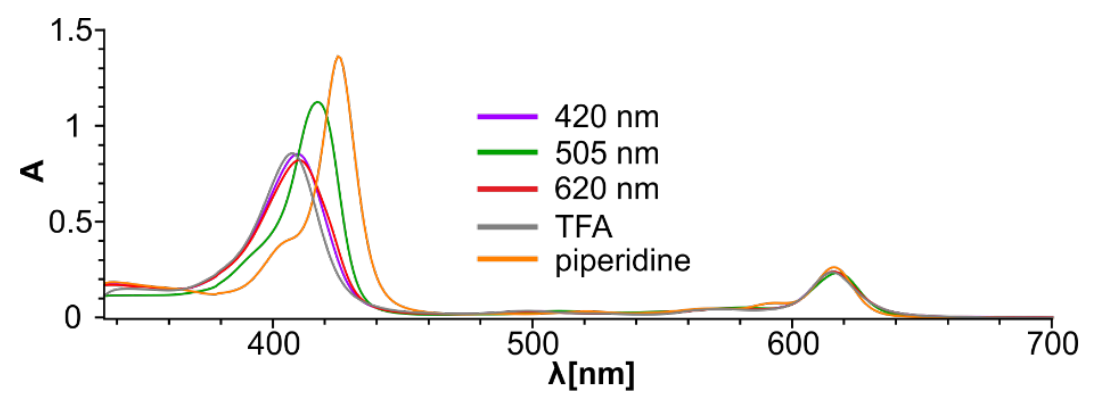

Fig. S56 UV-Vis spectra of $10 \mathrm{~b}$ in acetone $(7.50 \mu \mathrm{M})$ after irradiation with blue $(420 \mathrm{~nm})$, green (505 nm) and red (620 nm) light and after addition of piperidine and TFA. The amount of paramagnetic species after switching with green light $(505 \mathrm{~nm})$ is $91 \%$.

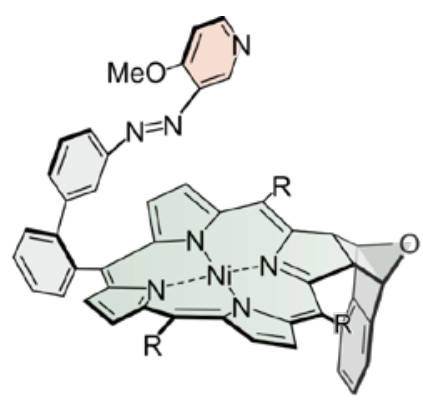

10b trans (diamagn.)

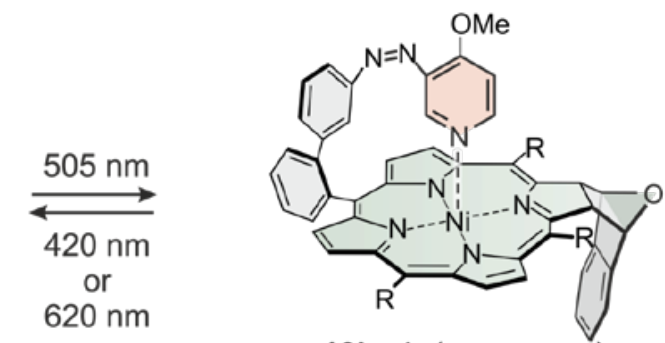

10b cis (paramagn.)

switching

efficiency

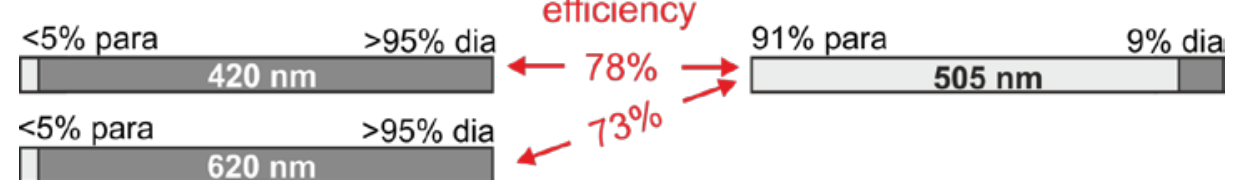

Fig. S57 Percentage of paramagnetic nickel ions after irradiation of $10 \mathrm{~b}(7.50 \mu \mathrm{M})$ in acetone at $25^{\circ} \mathrm{C}$ with 420, 505 and $620 \mathrm{~nm}$ light $\left(\mathrm{R}=\mathrm{C}_{6} \mathrm{~F}_{5}\right)$. 


\section{Bacteriochlorin RP 11 in Acetone}

After irradiation with $505 \mathrm{~nm}$ at $\lambda=740 \mathrm{~nm}$ :

$\mathrm{A}_{\text {obs }}=0.374, \mathrm{~A}_{\text {para } \max }=0.603, \mathrm{~A}_{\text {dia } \max }=0.0228$

$\mathrm{x}=(0.374-0.603) /(0.0228-0.603)=0.39$

$39 \%$ dia- and $61 \%$ paramagnetic species*
After irradiation with $420 \mathrm{~nm}$ at $\lambda=760 \mathrm{~nm}$ :

15\% paramagnetic species left

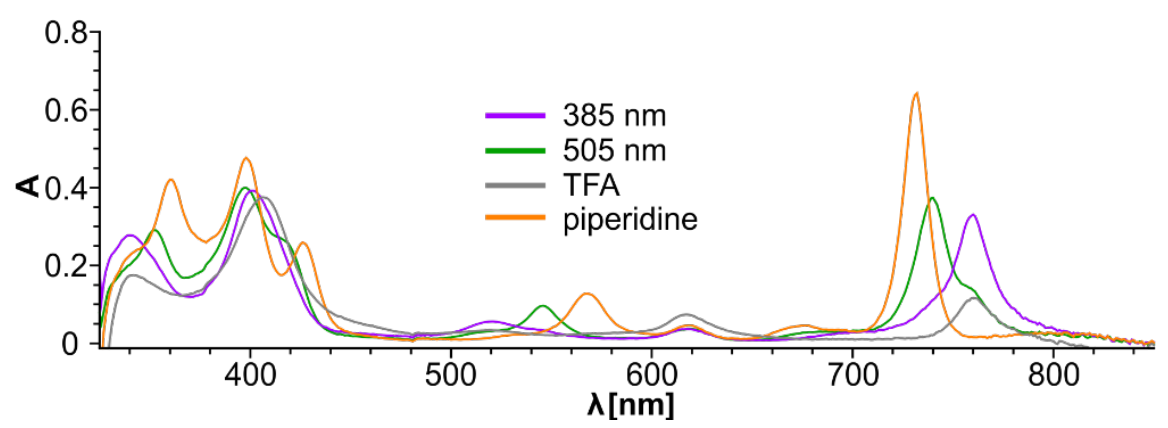

Fig. S58 UV-Vis spectra of $\mathbf{1 1}$ in acetone $(7.50 \mu \mathrm{M})$ after irradiation with blue $(385 \mathrm{~nm})$ and green (505 nm) light. The amount of paramagnetic species after switching with blue light (385 nm) is 15\%.

${ }^{*}$ Our assumption, that both extinction coefficients (5- and 6-coordinated species) are equal, doesn’t fit well for bacteriochlorin record player 11. Therefore, we determine the percentage of the paramagnetic species after irradiation with green light (505 nm, $5 \mathrm{~min}$ ) with ${ }^{1} \mathrm{H}$ NMR spectroscopy in acetone- $\mathrm{d}_{6}$. The integral of the pyrrol protons can be used to determine dia/para ratios. Due to axial coordination the pyrrol protons shift to $50.5 \mathrm{ppm}$. The pyrrol protons of the diamagnetic species appear at $9.2 \mathrm{ppm}$. So, integration of both pyrrol proton signals leads to the desired ratio of paramagnetic and diamagnetic species after on-switching (82\% para and 18\% dia, Fig. S59). 


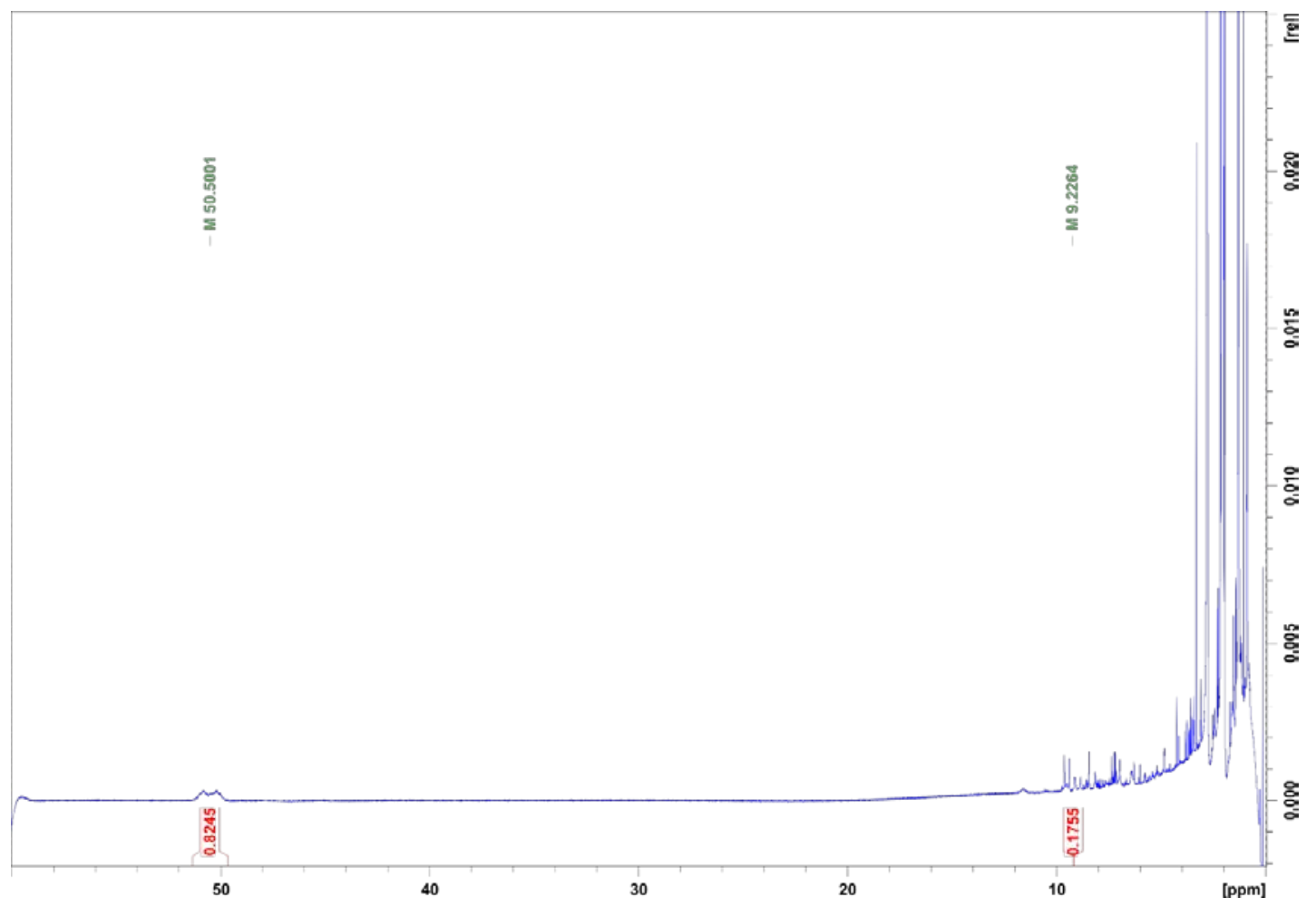

Fig. S59 Percentage of paramagnetic nickel ions upon irradiation of $\mathbf{1 1}(25 \mu \mathrm{M})$ in acetone at $25^{\circ} \mathrm{C}$ with $505 \mathrm{~nm}$ light.

A long-time back switching experiment of compound $\mathbf{1 1}$ in acetone with red light is shown in Fig. S60 and S61. The back switching with red light leads to degradation of bacteriochlorin $\mathbf{1 1}$ to a chlorin (band at $417 \mathrm{~nm}$ ), which is also indicated by the absence of an isosbestic point.

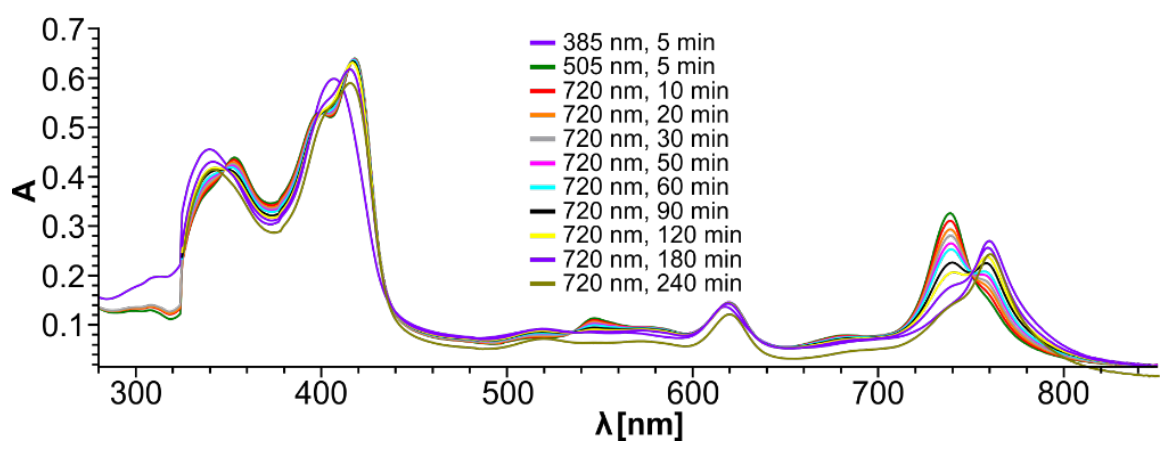

Fig. S60 UV-Vis spectra of $\mathbf{1 1}$ in acetone after irradiation with blue (385 nm), green (505 nm) and red (720 nm) light. 


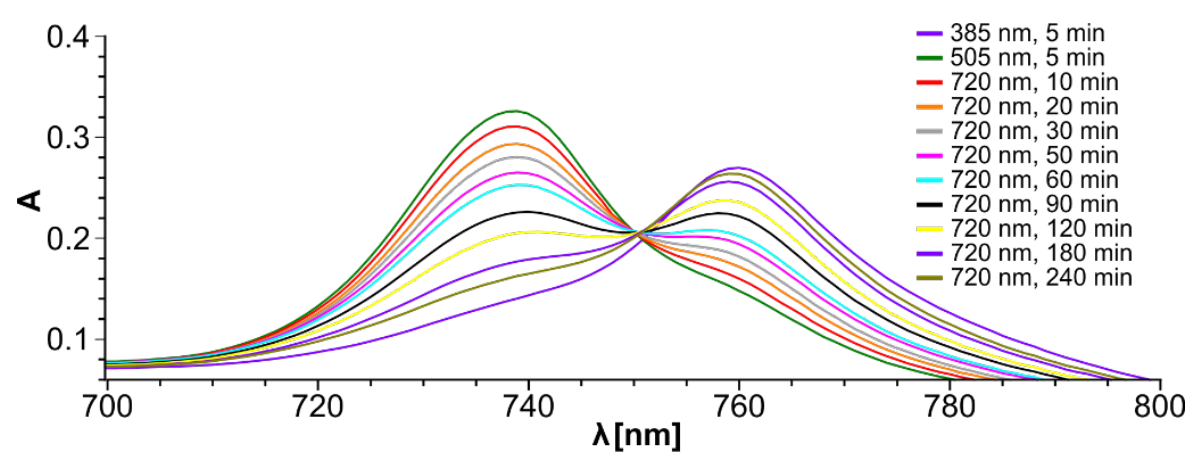

Fig. S61 Zoom into the Q band region of $\mathbf{1 1}$ in acetone after irradiation with blue (385 $\mathrm{nm}$ ), green (505 nm) and red (720 nm) light. After long-time irradiation with $720 \mathrm{~nm}$ light $16 \%$ of the paramagnetic species is left.

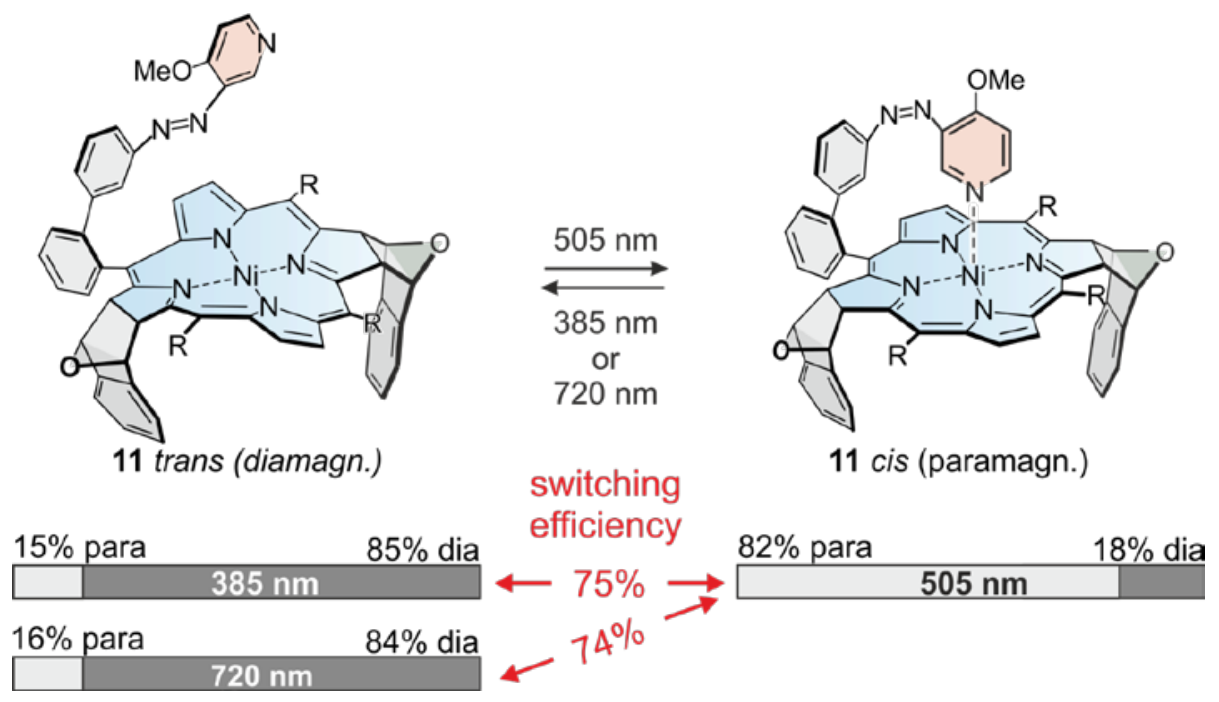

Fig. S62 Percentage of paramagnetic nickel ions upon irradiation of $\mathbf{1 1}(7.50 \mu \mathrm{M})$ in acetone at $25^{\circ} \mathrm{C}$ with 385, 505 and $720 \mathrm{~nm}$ light $\left(\mathrm{R}=\mathrm{C}_{6} \mathrm{~F}_{5}\right)$. 


\section{Chlorin RP G2.0 12a in Water}

After irradiation with $505 \mathrm{~nm}$ at $\lambda=431 \mathrm{~nm}$ :

$\mathrm{A}_{\text {obs }}=0.968, \mathrm{~A}_{\text {para } \max }=1.60, \mathrm{~A}_{\text {dia } \max }=0.532$

$\mathrm{x}=(0.968-1.60) /(0.532-1.60)=0.59$

$59 \%$ dia- and $41 \%$ paramagnetic species
After irradiation with $420 \mathrm{~nm}$ at $\lambda=417 \mathrm{~nm}$ :

95\% dia- and 5\% paramagnetic species

After irradiation with $620 \mathrm{~nm}$ at $\lambda=419 \mathrm{~nm}$ :

94\% dia- and 6\% paramagnetic species

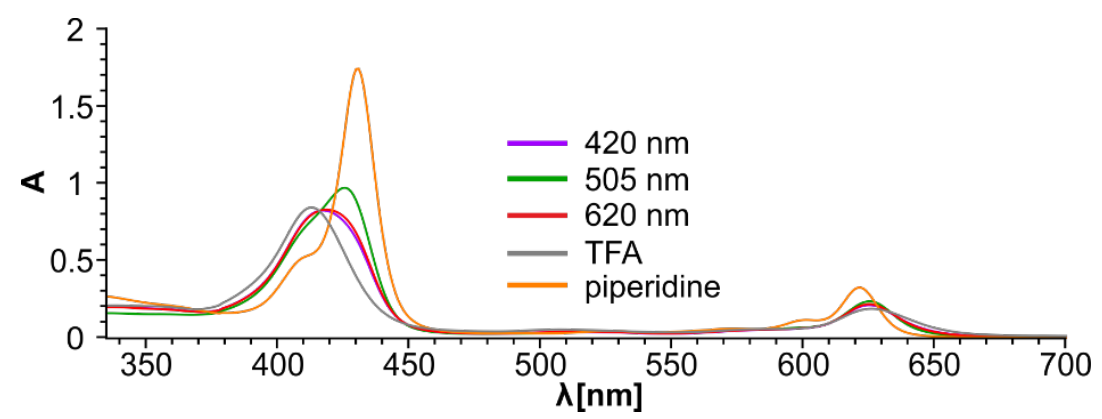

Fig. S63 UV-Vis spectra of 12a in water $(8.93 \mu \mathrm{M})$ after irradiation with blue (420 nm), green (505 nm) and red $(620 \mathrm{~nm})$ light and after addition of piperidine and TFA. The amount of paramagnetic species after switching with green light $(505 \mathrm{~nm})$ is $41 \%$.

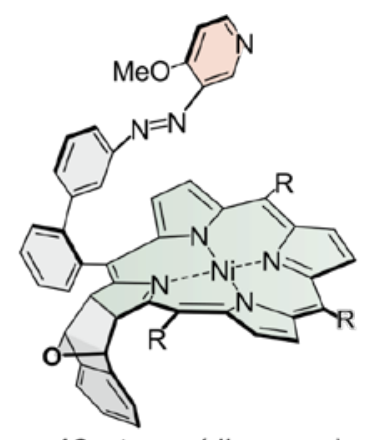

12a trans (diamagn.)

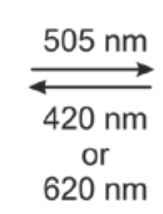

switching efficiency
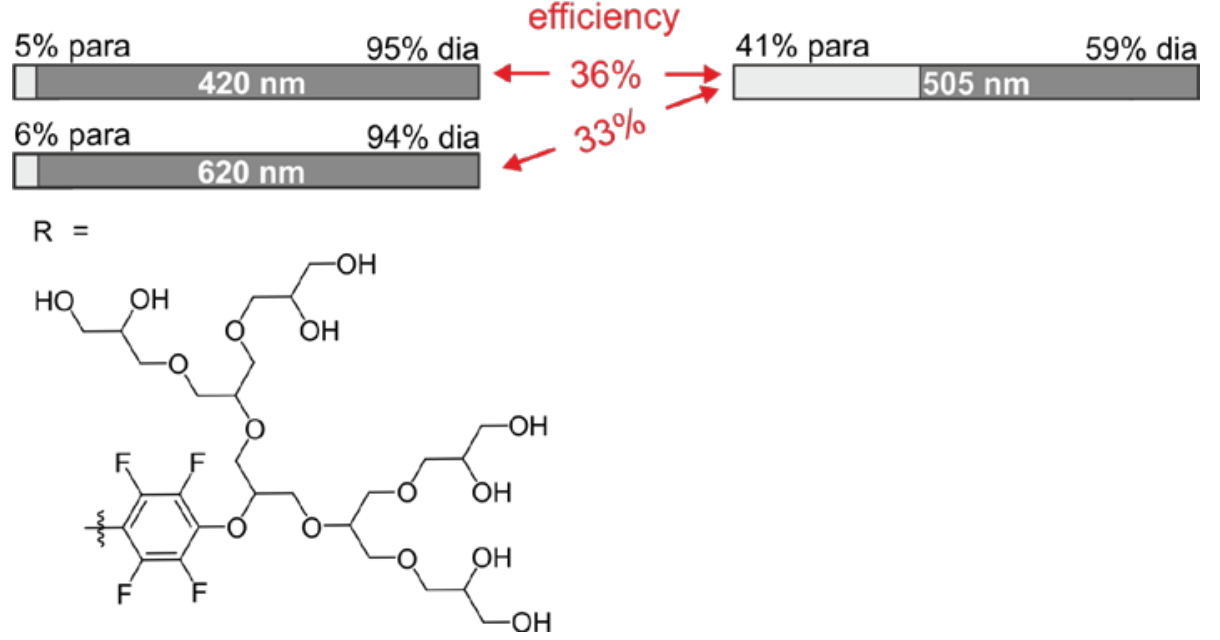

Fig. S64 Percentage of paramagnetic nickel ions upon irradiation of $\mathbf{1 2 a}(8.93 \mu \mathrm{M})$ in water at $25^{\circ} \mathrm{C}$ with 420 and $505 \mathrm{~nm}$ light. 


\section{Chlorin RP G2.0 12a in Methanol}

After irradiation with $505 \mathrm{~nm}$ at $\lambda=424 \mathrm{~nm}$ :

$\mathrm{A}_{\text {obs }}=1.88, \mathrm{~A}_{\text {para } \max }=1.90, \mathrm{~A}_{\text {dia } \max }=0.702$

$\mathrm{x}=(1.88-1.90) /(0.702-1.90)=0.01$

$1 \%$ dia- and $99 \%$ paramagnetic species
After irradiation with $420 \mathrm{~nm}$ at $\lambda=413 \mathrm{~nm}$ :

96\% dia- and 4\% paramagnetic species

After irradiation with $620 \mathrm{~nm}$ at $\lambda=419 \mathrm{~nm}$ :

98\% dia- and 2\% paramagnetic species

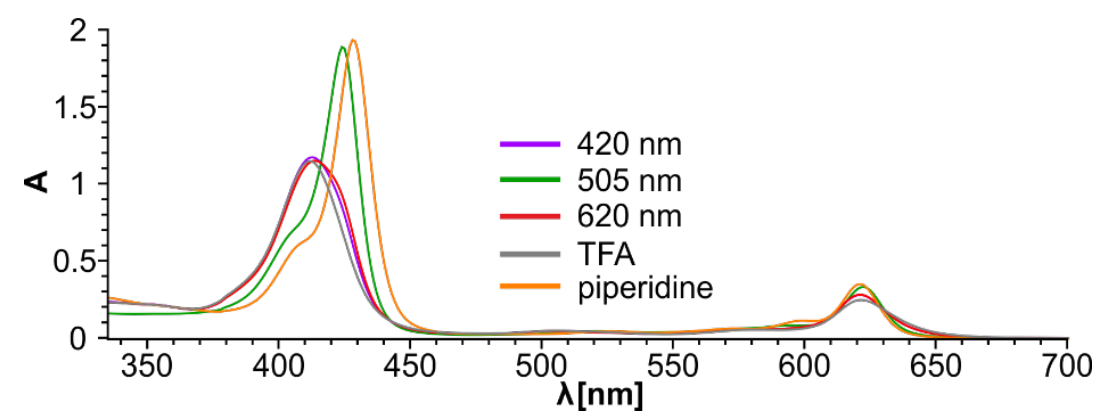

Fig. S65 UV-Vis spectra of 12a in methanol $(8.93 \mu \mathrm{M})$ after irradiation with blue ( $420 \mathrm{~nm}$ ), green (505 nm) and red (620 nm) light and after addition of piperidine and TFA. The amount of paramagnetic species after switching with green light $(505 \mathrm{~nm})$ is $99 \%$.

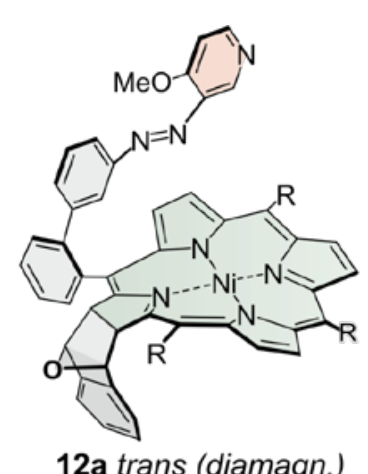

12a trans (diamagn.)
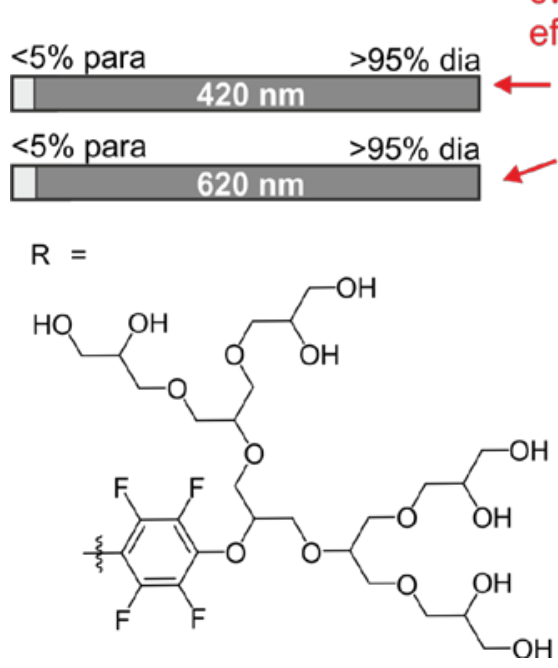

Fig. S66 Percentage of paramagnetic nickel ions upon irradiation of $12 a(8.93 \mu \mathrm{M})$ in methanol at $25^{\circ} \mathrm{C}$ with 420 and 505 nm light. 


\section{Chlorin RP G2.0 12b in Water}

After irradiation with $505 \mathrm{~nm}$ at $\lambda=421 \mathrm{~nm}$ :

$\mathrm{A}_{\text {obs }}=1.05, \mathrm{~A}_{\text {para } \max }=1.67, \mathrm{~A}_{\text {dia } \max }=0.651$

$\mathrm{x}=(1.05-1.67) /(0.651-1.67)=0.61$

61\% dia- and 39\% paramagnetic species
After irradiation with $420 \mathrm{~nm}$ at $\lambda=417 \mathrm{~nm}$ :

95\% dia- and 5\% paramagnetic species

After irradiation with $620 \mathrm{~nm}$ at $\lambda=419 \mathrm{~nm}$ :

94\% dia- and 6\% paramagnetic species

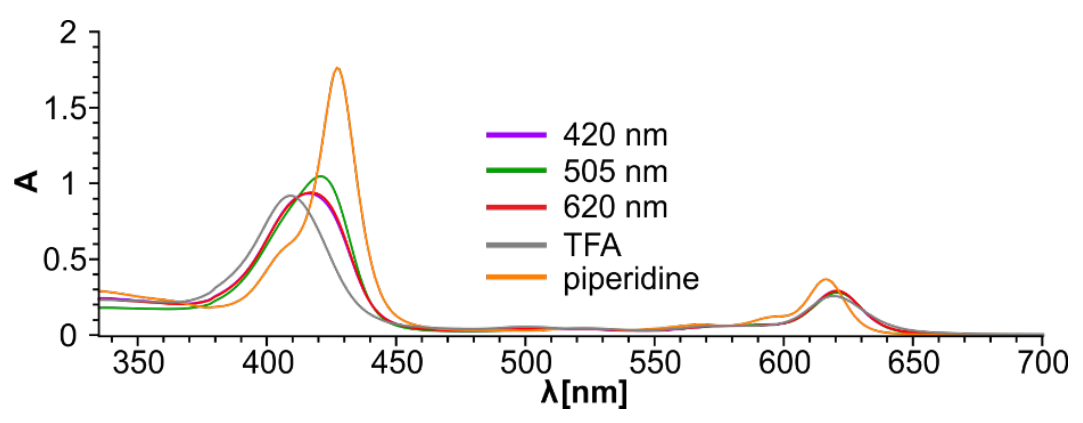

Fig. S67 UV-Vis spectra of $\mathbf{1 2 b}$ in water $(8.93 \mu \mathrm{M})$ after irradiation with blue (420 nm), green (505 nm) and red $(620 \mathrm{~nm})$ light and after addition of piperidine and TFA. The amount of paramagnetic species after switching with green light (505 nm) is 39\%.

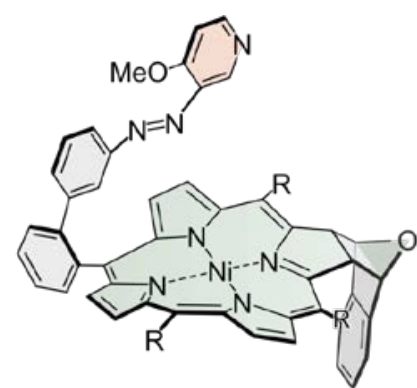

12b trans (diamagn.)

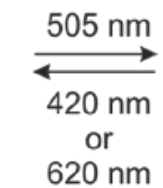

switching

efficiency

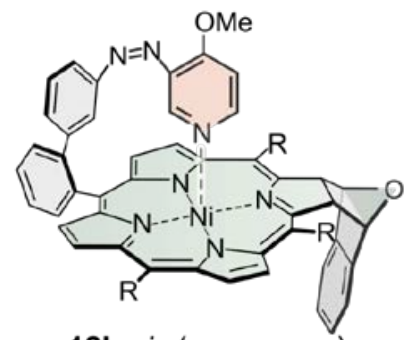

12b cis (paramagn.)
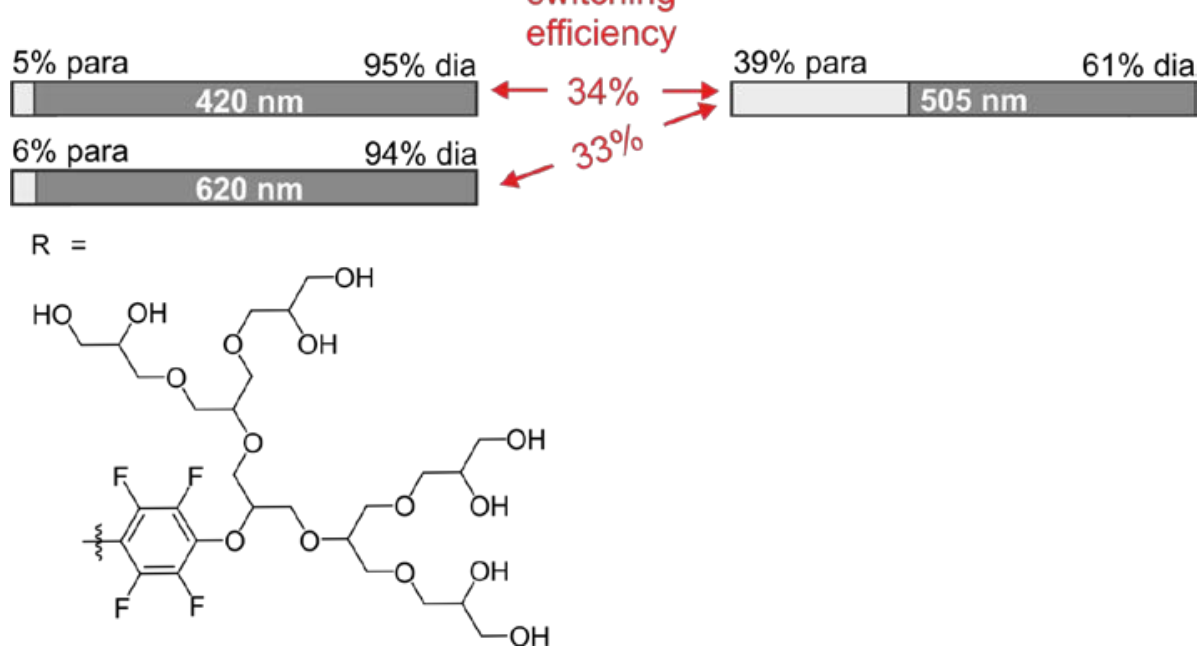

Fig. S68 Percentage of paramagnetic nickel ions after irradiation of $\mathbf{1 2 b}(8.93 \mu \mathrm{M})$ in water at $25^{\circ} \mathrm{C}$ with 420, 505 and $620 \mathrm{~nm}$ light. 


\section{Chlorin RP G2.0 12b in Methanol}

After irradiation with $505 \mathrm{~nm}$ at $\lambda=422 \mathrm{~nm}$ :

$\mathrm{A}_{\text {obs }}=1.79, \mathrm{~A}_{\text {para } \max }=1.91, \mathrm{~A}_{\text {dia } \max }=0.731$

$\mathrm{x}=(1.79-1.91) /(0.731-1.91)=0.09$

9\% dia- and 91\% paramagnetic species
After irradiation with $420 \mathrm{~nm}$ at $\lambda=410 \mathrm{~nm}$ :

98\% dia- and 2\% paramagnetic species

After irradiation with $620 \mathrm{~nm}$ at $\lambda=410 \mathrm{~nm}$ :

97\% dia- and 3\% paramagnetic species

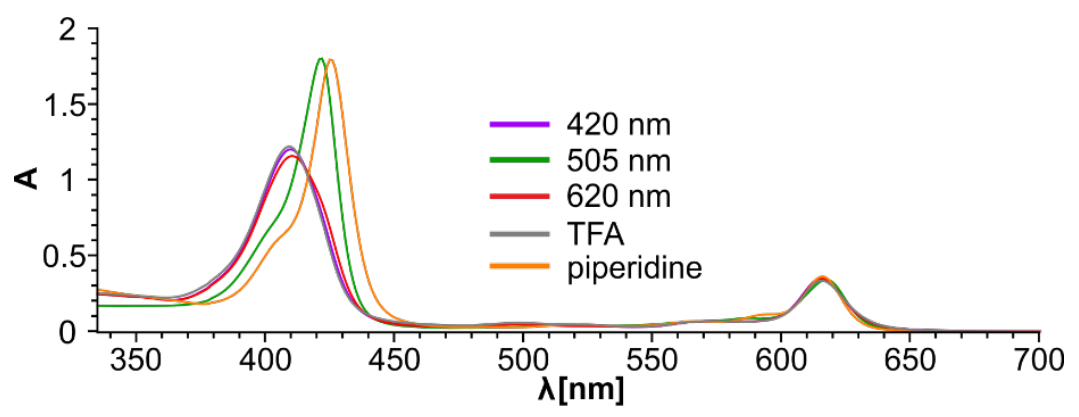

Fig. S69 UV-Vis spectra of $\mathbf{1 2 b}$ in methanol $(8.93 \mu \mathrm{M})$ after irradiation with blue $(420 \mathrm{~nm})$, green (505 nm) and red (620 nm) light and after addition of piperidine and TFA. The amount of paramagnetic species after switching with green light (505 nm) is 91\%.

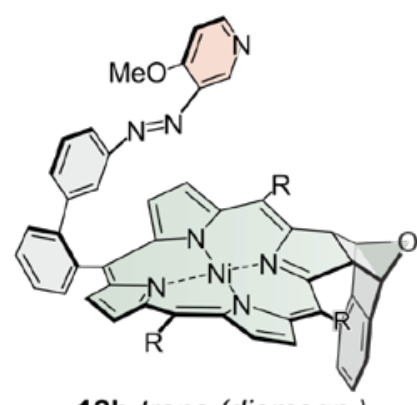

12b trans (diamagn.)

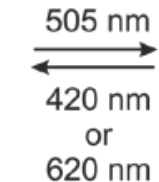

switching

efficiency

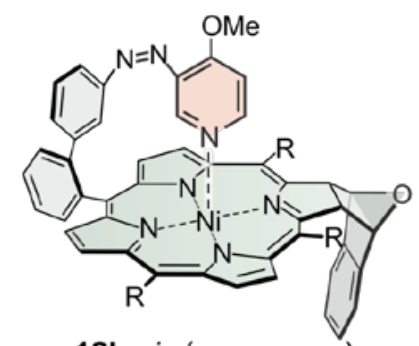

12b cis (paramagn.)
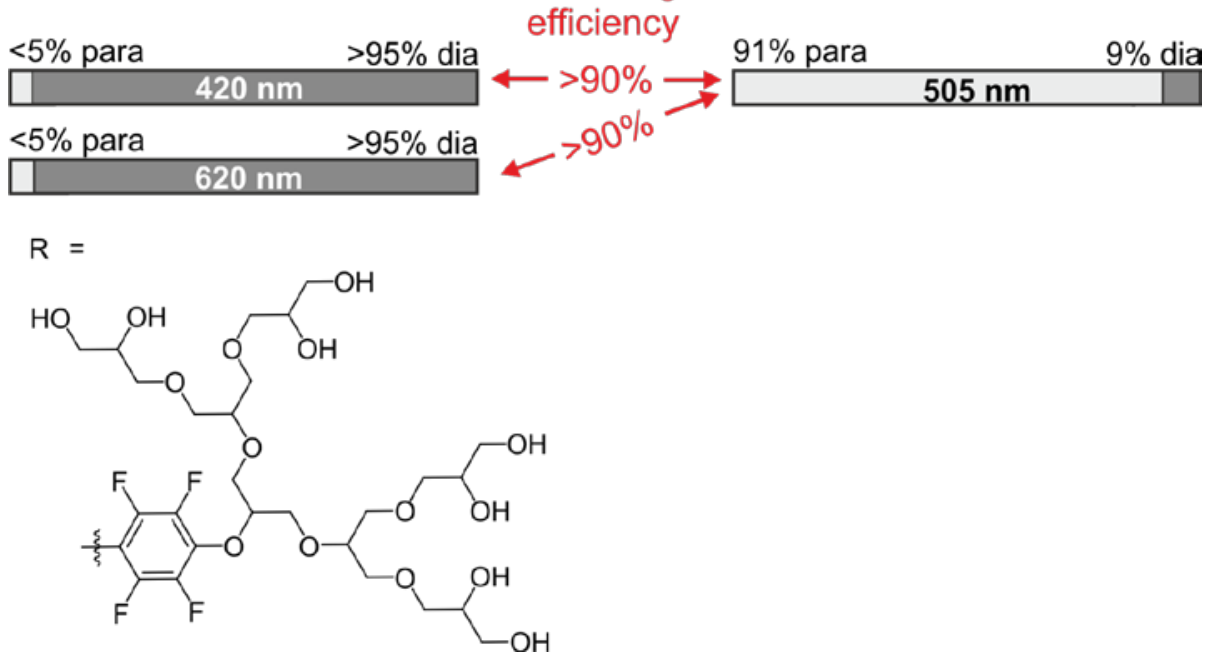

Fig. S70 Percentage of paramagnetic nickel ions after irradiation of $\mathbf{1 2 b}(8.93 \mu \mathrm{M})$ in methanol at $25^{\circ} \mathrm{C}$ with 420, 505 and $620 \mathrm{~nm}$ light. 


\section{V.3 Summary of Switching Behaviors}
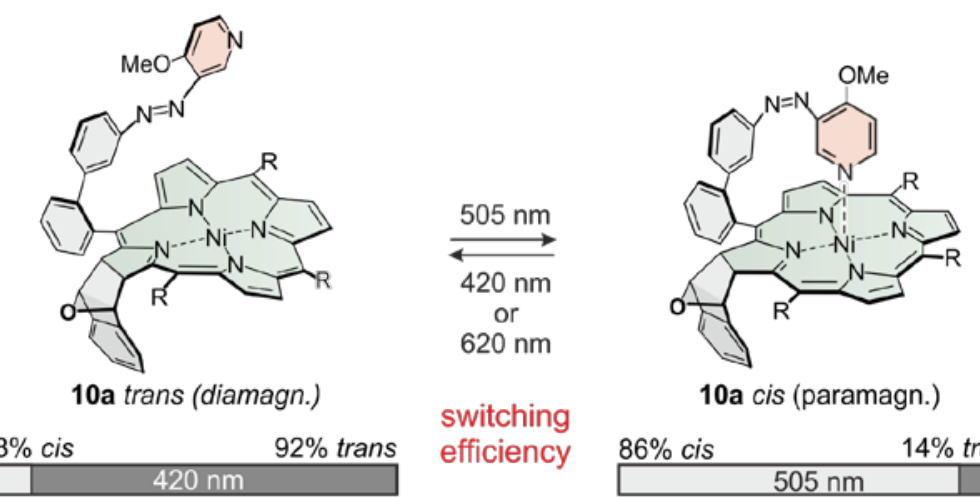

switching efficiency

$$
\text { 10a cis (paramagn.) }
$$

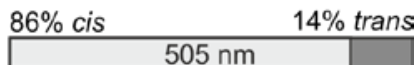

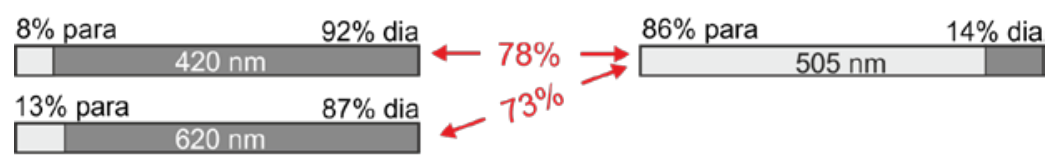
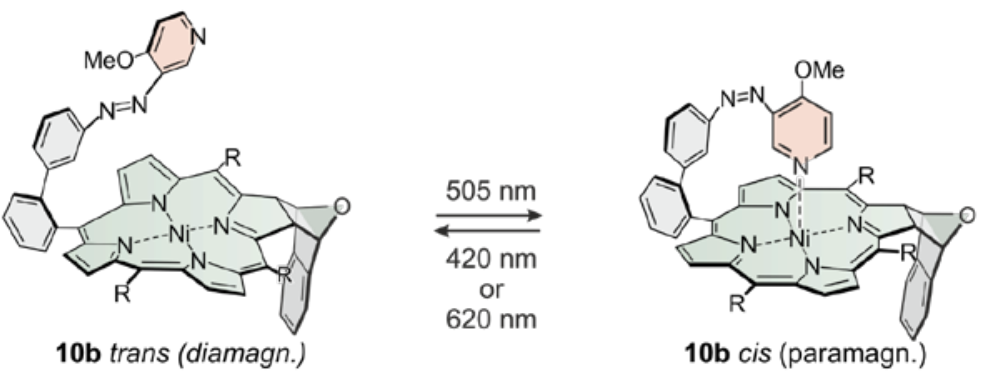

cis/trans ratio not determinable

switching efficiency

\section{cis/trans ratio not determinable}

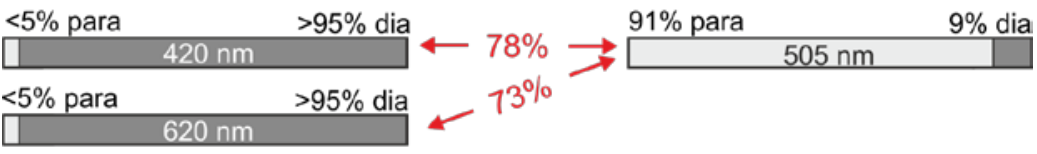
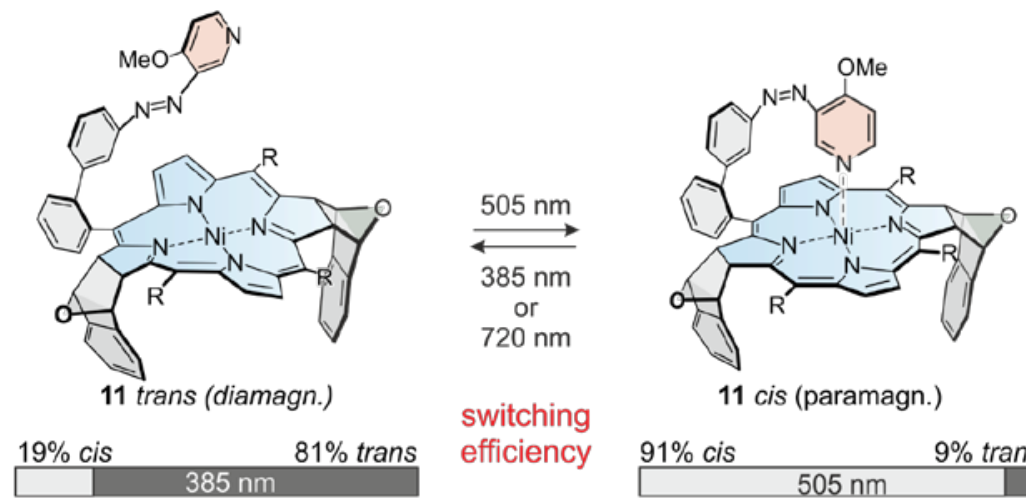

efficiency
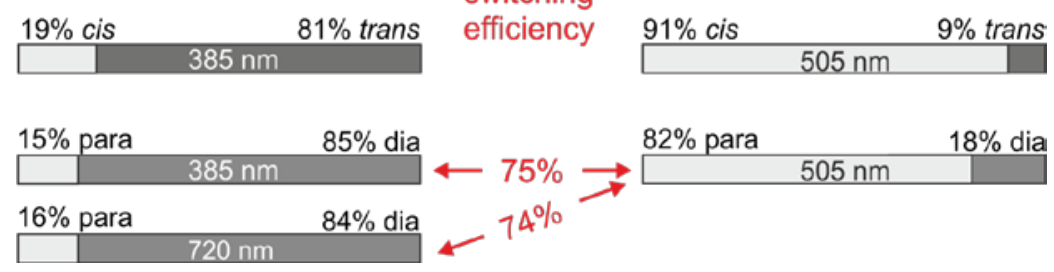

Fig. S71 Photostationary states (\% cis isomer, PSS) and switching efficiencies of RP 10a, 10b and 11 in acetone. cis/trans ratios are determined with ${ }^{1} \mathrm{H}$ NMR spectroscopy and dia/para ratios are based on $\mathrm{UV}$-vis data $\left(\mathrm{R}=\mathrm{C}_{6} \mathrm{~F}_{5}\right)$. 


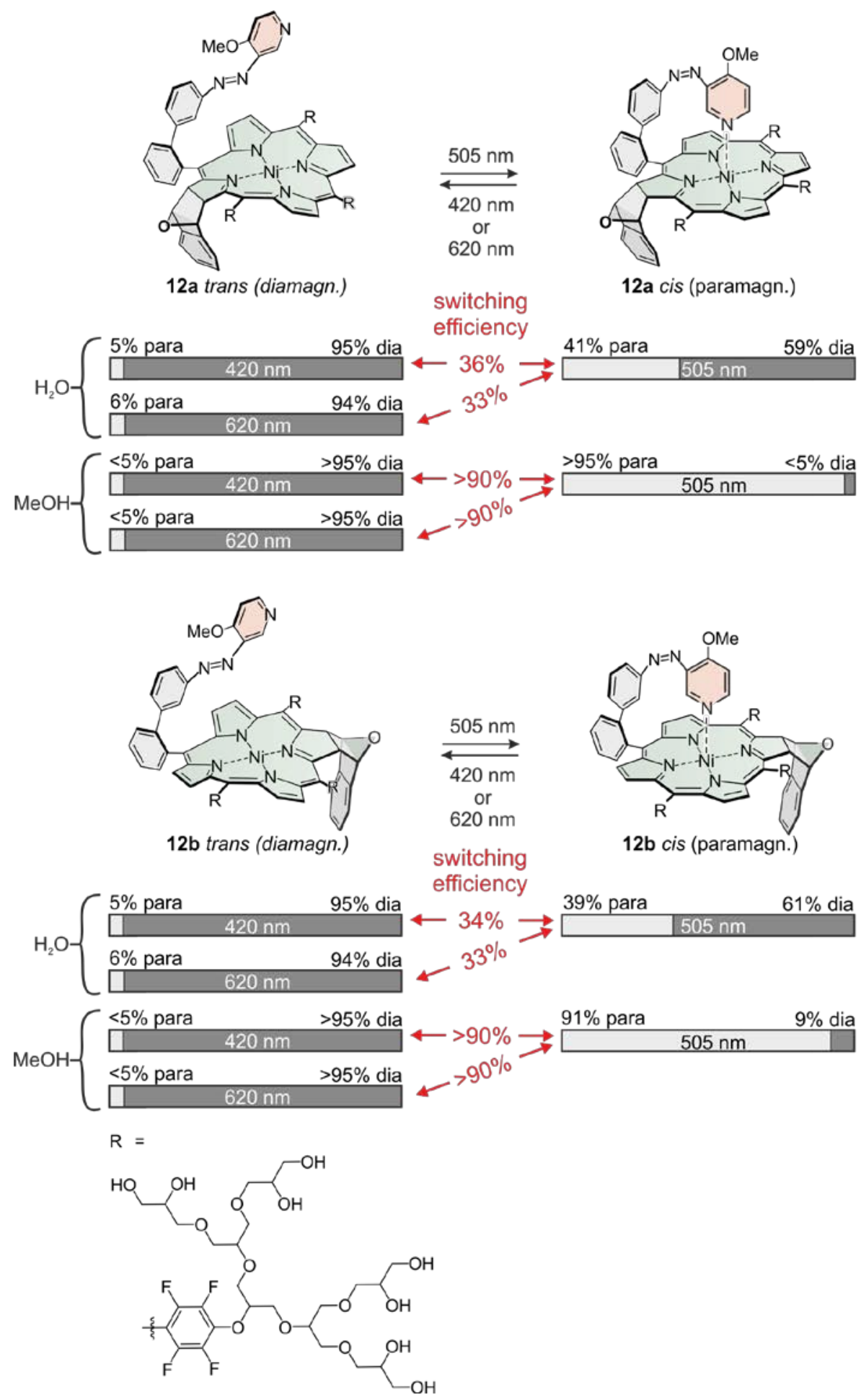

Fig. S72 Switching parameters and switching efficiencies of RP 12a (top) and 12b (bottom) in water and methanol based on UV-vis data. 


\section{NMR Spectra}

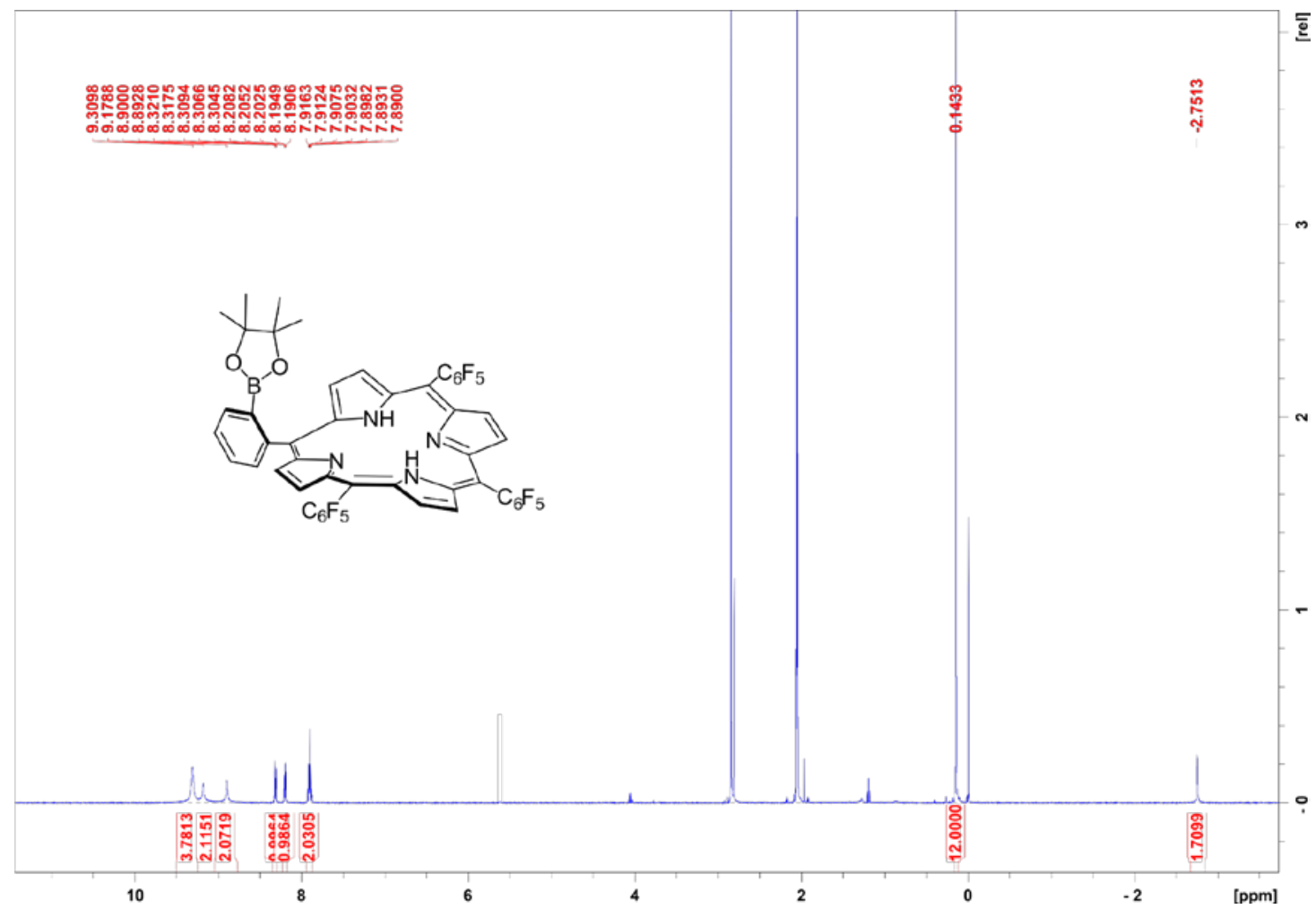

Fig. S73a ${ }^{1} \mathrm{H}$ NMR of 5-(Phenyl-2'-(boronic acid pinacol ester))-10,15,20-tris(pentafluorophenyl)porphyrin $\mathbf{4}-\mathbf{H}_{2}$ in acetone- $\mathrm{d}_{6}$.

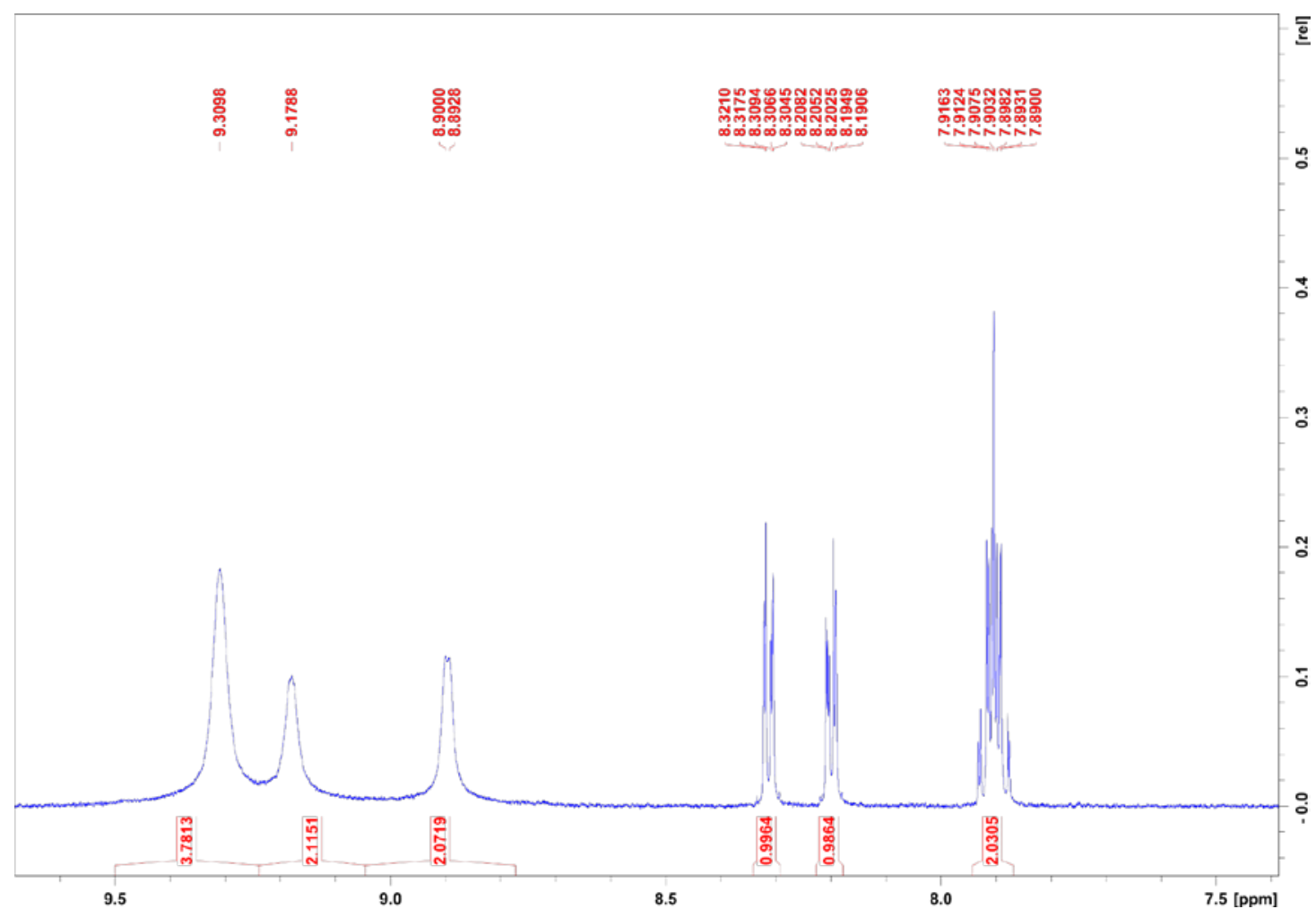

Fig. S73b Zoom of ${ }^{1} \mathrm{H} \quad$ NMR of $\quad$ 5-(Phenyl-2'-(boronic acid pinacol ester))-10,15,20tris(pentafluorophenyl)-porphyrin $\mathbf{4 - \mathbf { H } _ { 2 }}$ in acetone- $\mathrm{d}_{6}$. 


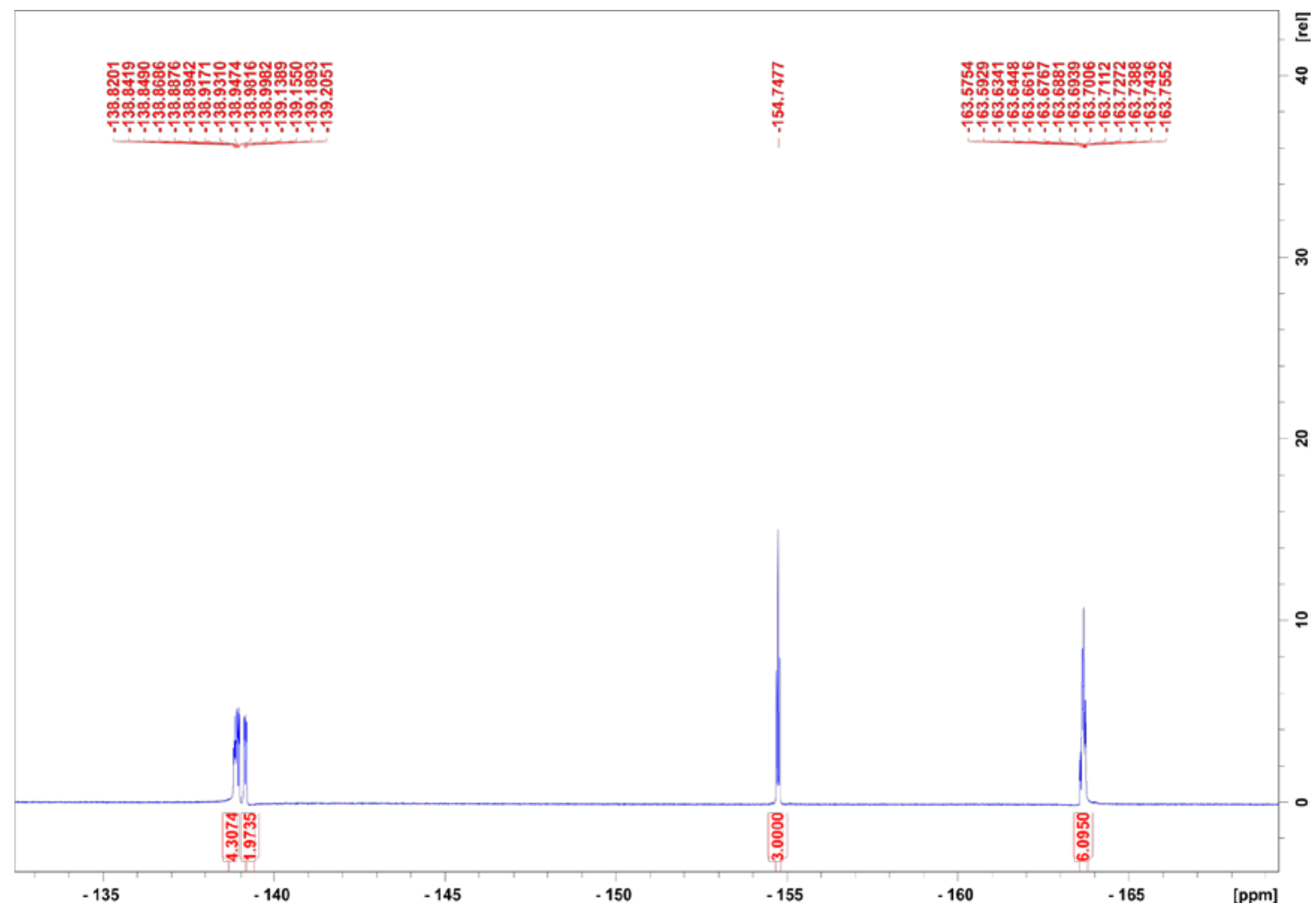

Fig. S73c ${ }^{19} \mathrm{~F}$ NMR of 5-(Phenyl-2'-(boronic acid pinacol ester))-10,15,20-tris(pentafluorophenyl)porphyrin $\mathbf{4 - \mathbf { H } _ { 2 }}$ in acetone- $\mathrm{d}_{6}$.

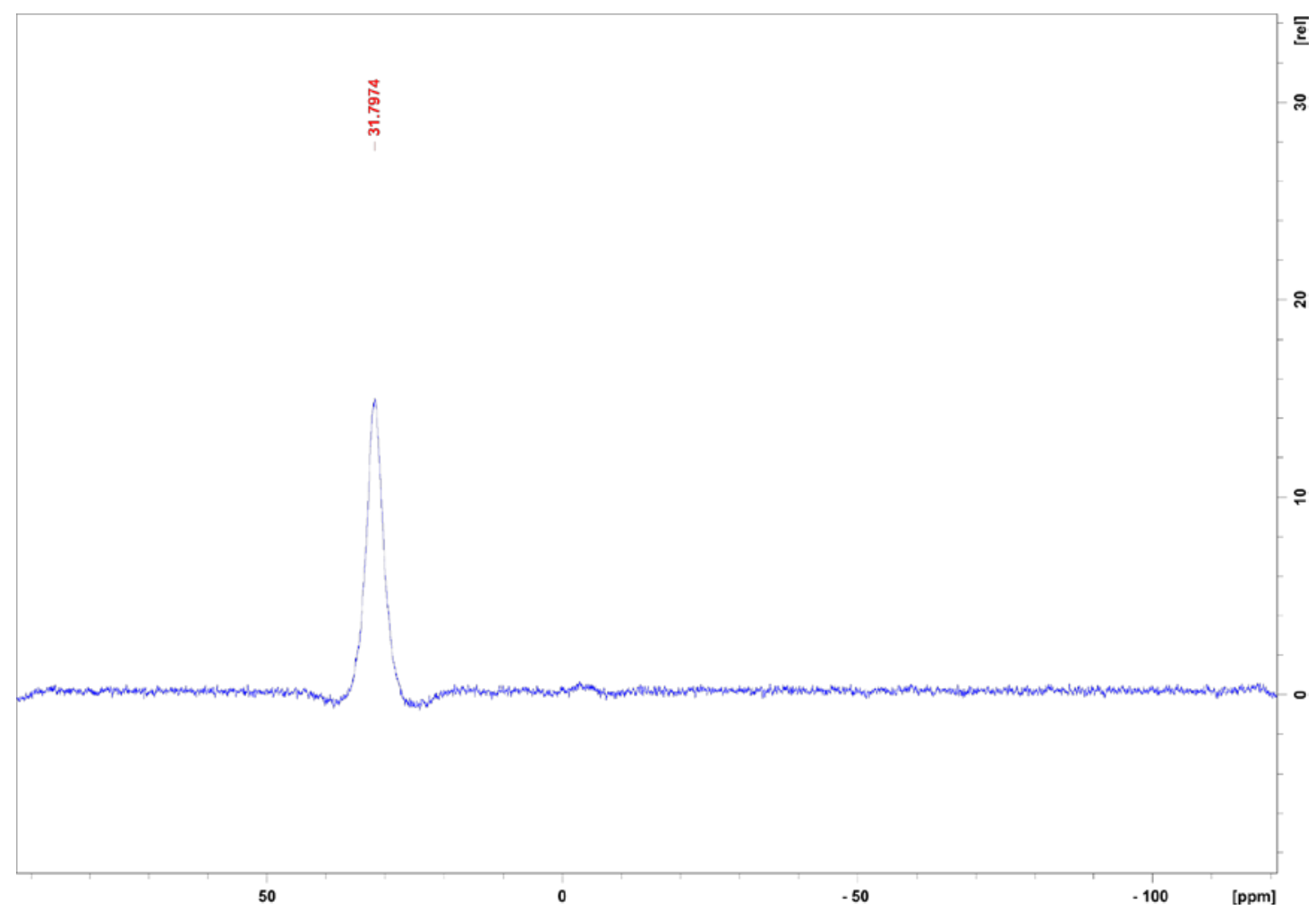

Fig. S73d ${ }^{11}$ B NMR of 5-(Phenyl-2'-(boronic acid pinacol ester))-10,15,20-tris(pentafluorophenyl)porphyrin $\mathbf{4}-\mathbf{H}_{2}$ in acetone- $\mathrm{d}_{6}$. 


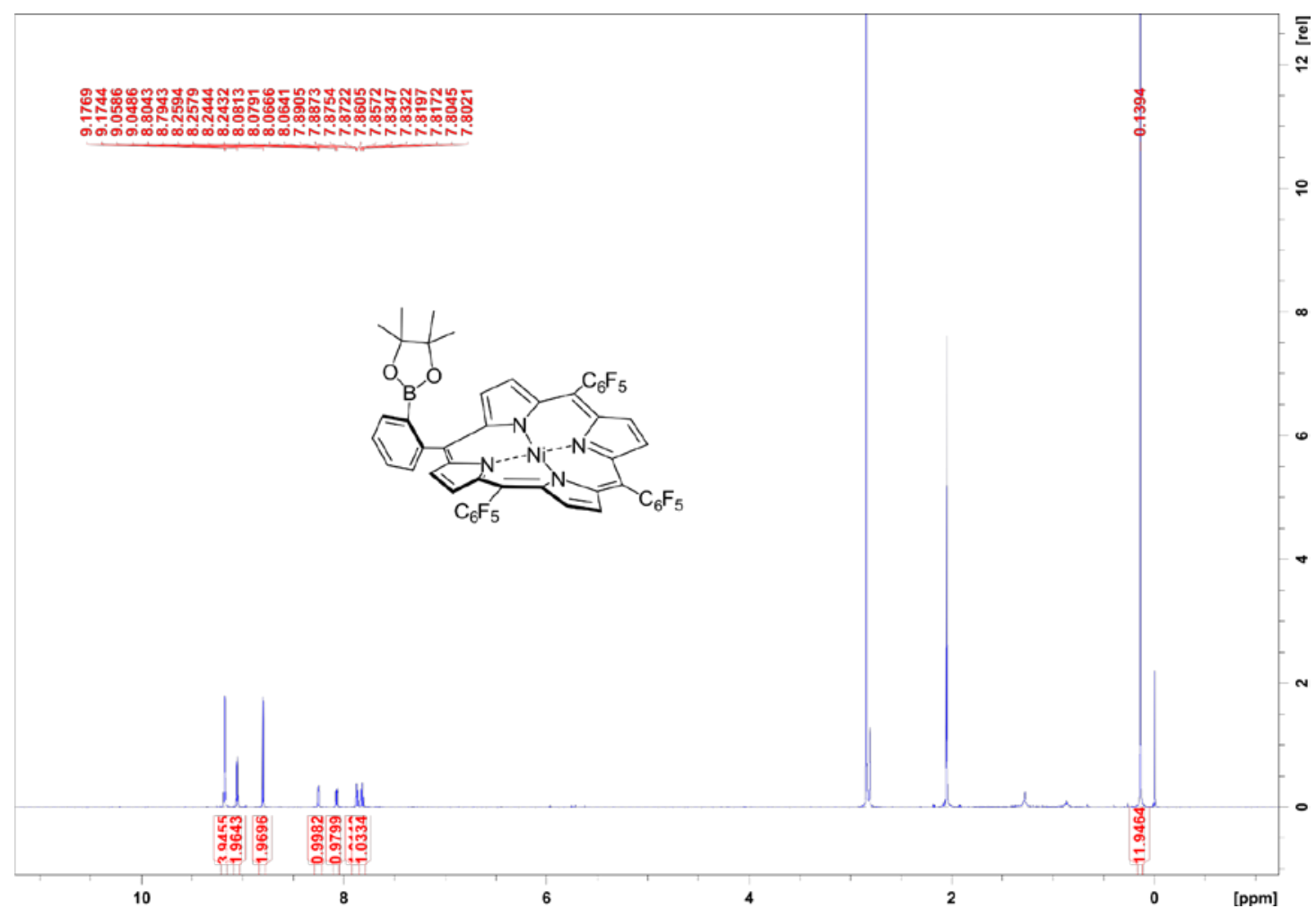

Fig. S74a ${ }^{1} \mathrm{H}$ NMR of 5-(Phenyl-2'-(boronic acid pinacol ester))-10,15,20-tris(pentafluorophenyl)$\mathrm{Ni}(\mathrm{II})$ porphyrin $4-\mathrm{Ni}$ in acetone- $\mathrm{d}_{6}$.

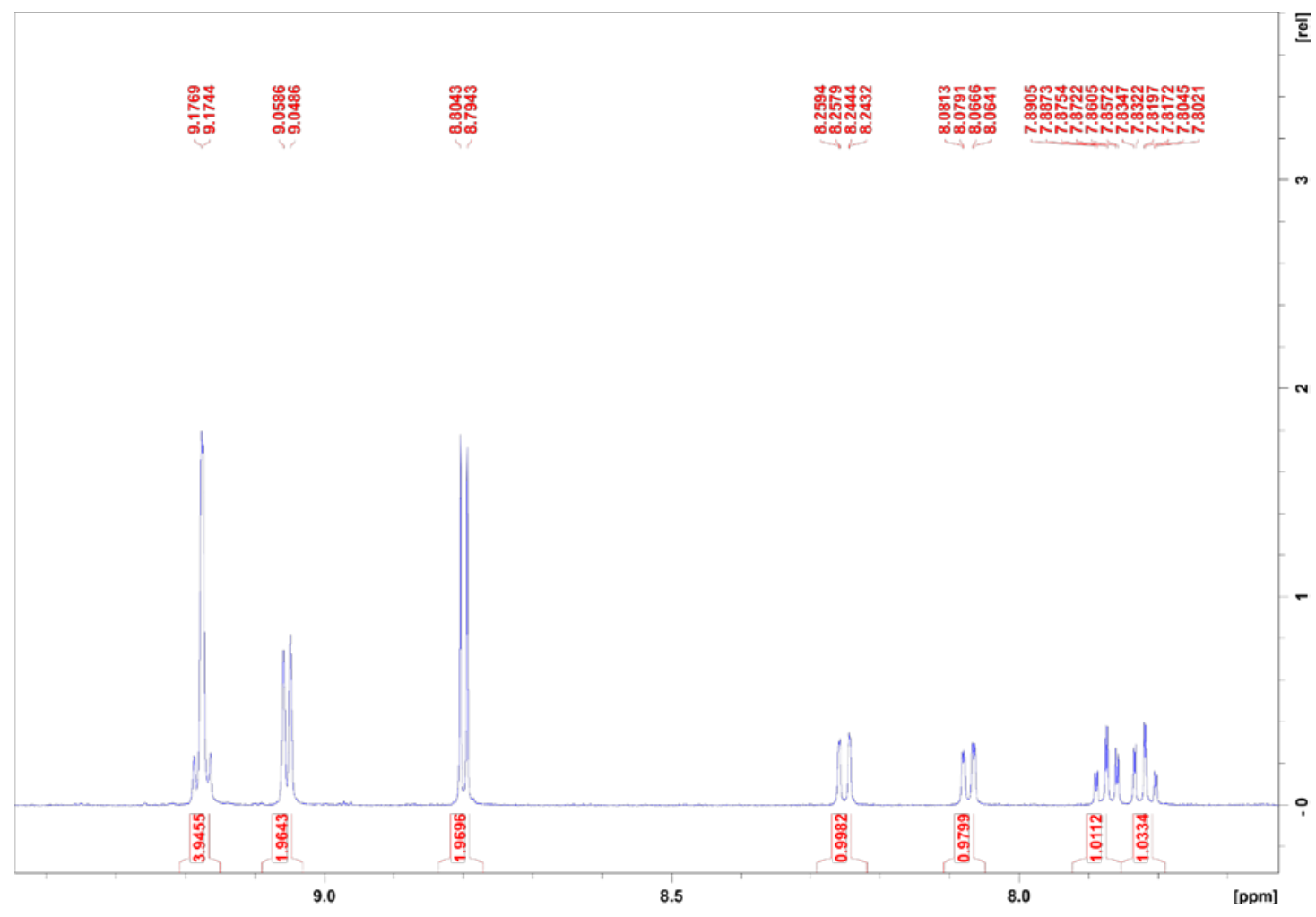

Fig. S74b Zoom of ${ }^{1} \mathrm{H} \quad$ NMR of 5-(Phenyl-2'-(boronic acid pinacol ester))-10,15,20tris(pentafluorophenyl)-Ni(II)porphyrin 4-Ni in acetone- $\mathrm{d}_{6}$. 


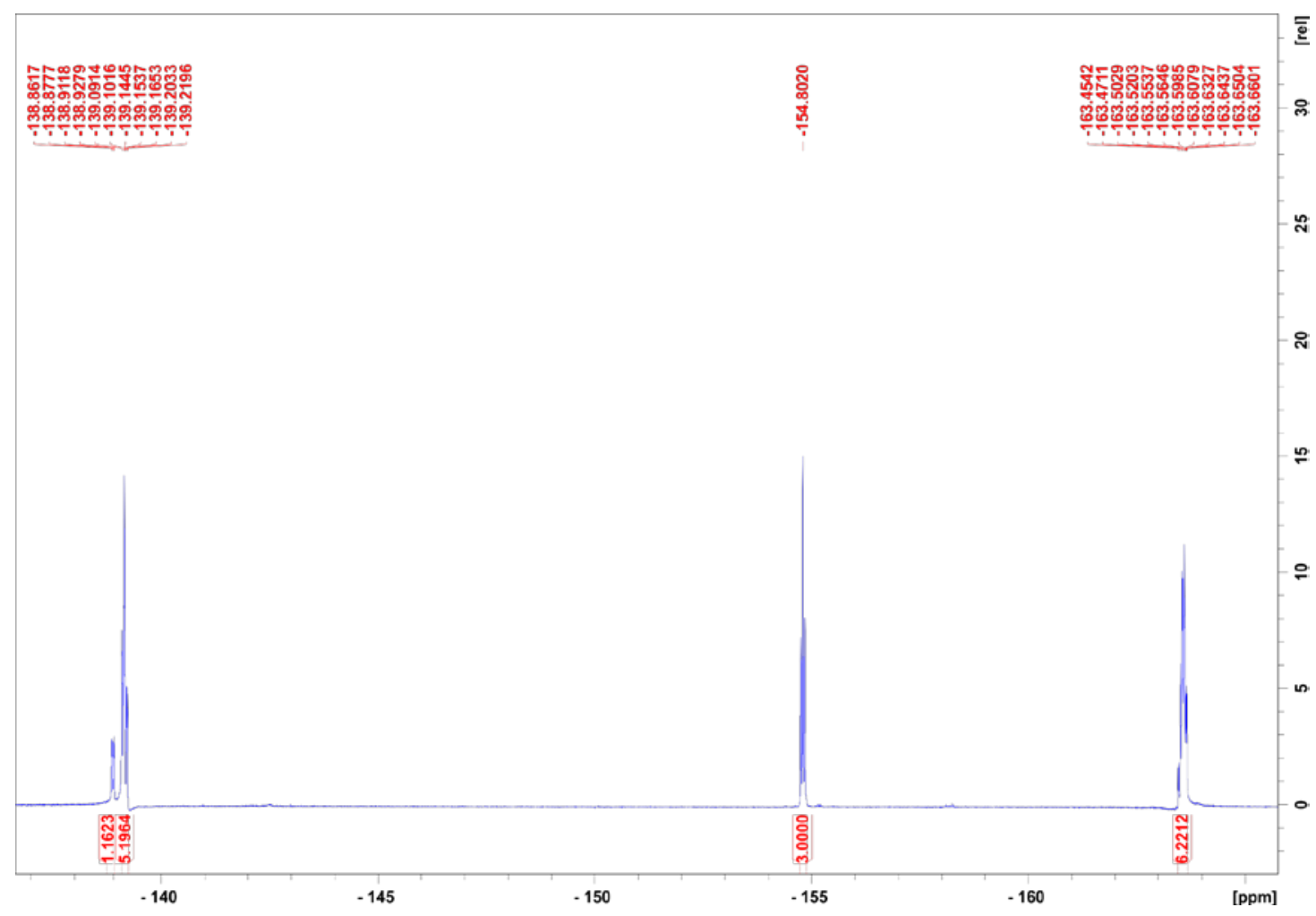

Fig. S74c ${ }^{19} \mathrm{~F}$ NMR of 5-(Phenyl-2'-(boronic acid pinacol ester))-10,15,20-tris(pentafluorophenyl)$\mathrm{Ni}(\mathrm{II})$ porphyrin $4-\mathrm{Ni}$ in acetone- $\mathrm{d}_{6}$.

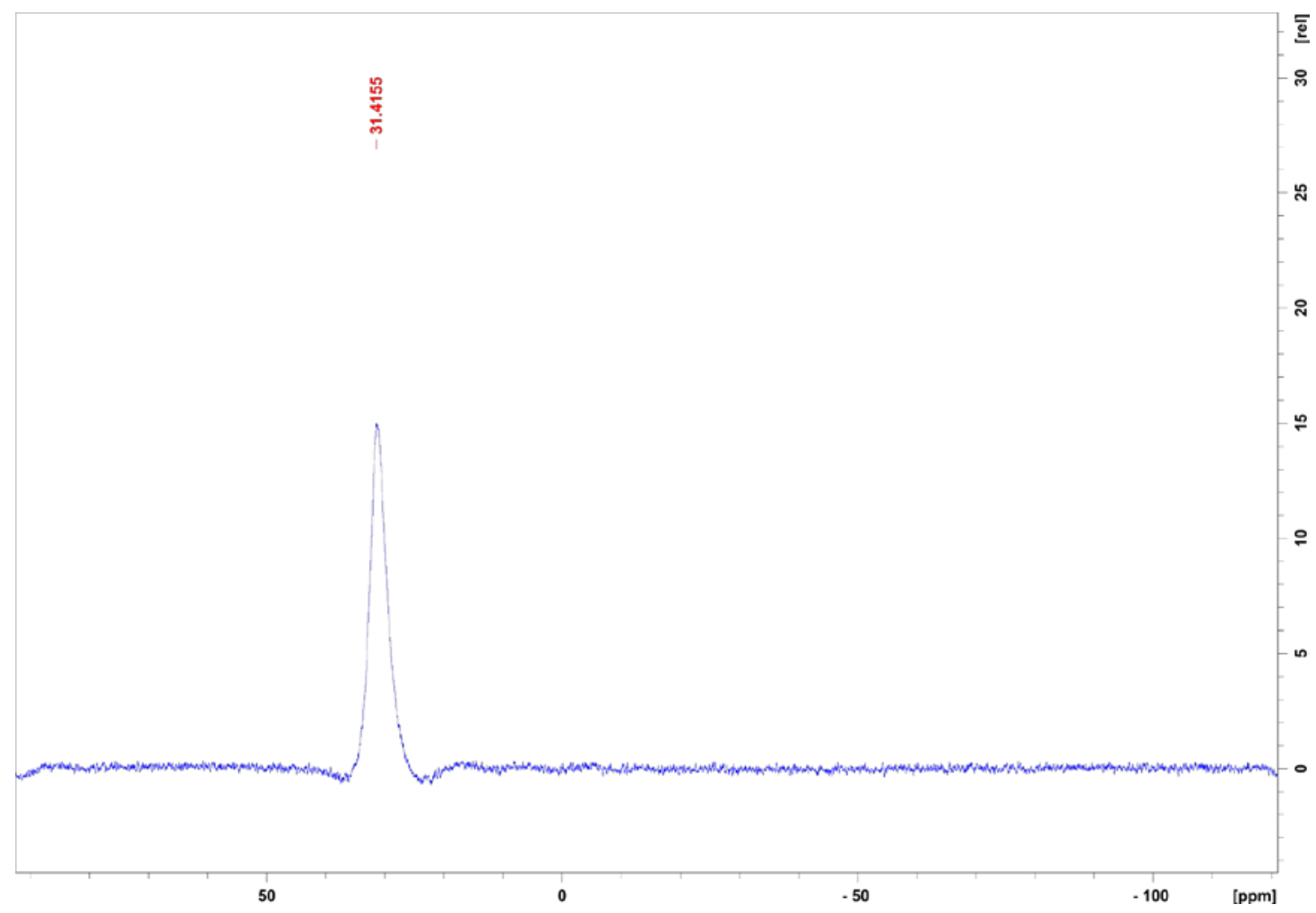

Fig. S74d ${ }^{11}$ B NMR of 5-(Phenyl-2'-(boronic acid pinacol ester))-10,15,20-tris(pentafluorophenyl)$\mathrm{Ni}(\mathrm{II})$ porphyrin 4-Ni in acetone- $\mathrm{d}_{6}$. 


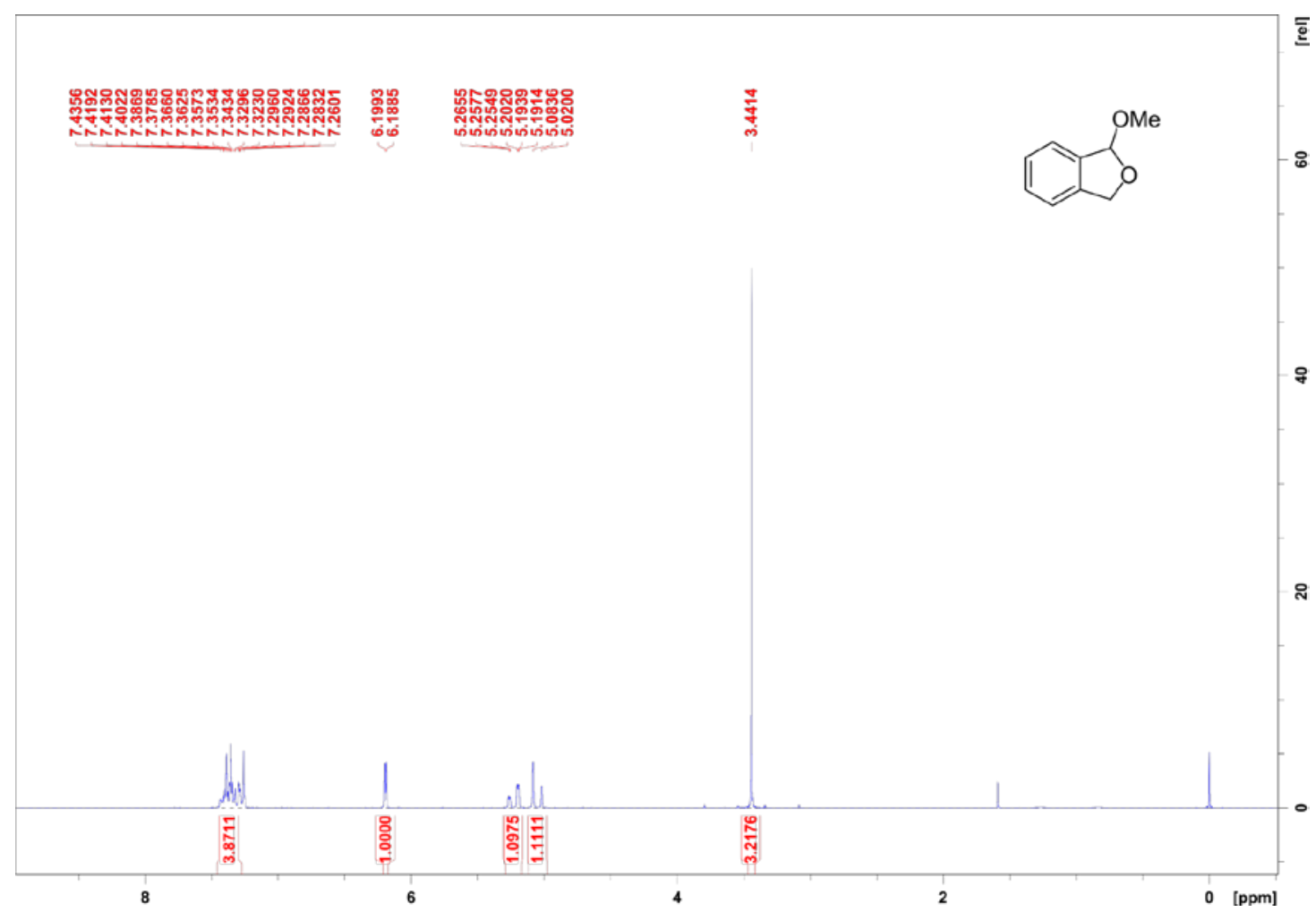

Fig. S75a ${ }^{1} \mathrm{H}$ NMR of 1,3-Dihydro-1-methoxyisobenzofuran in $\mathrm{CDCl}_{3}$.

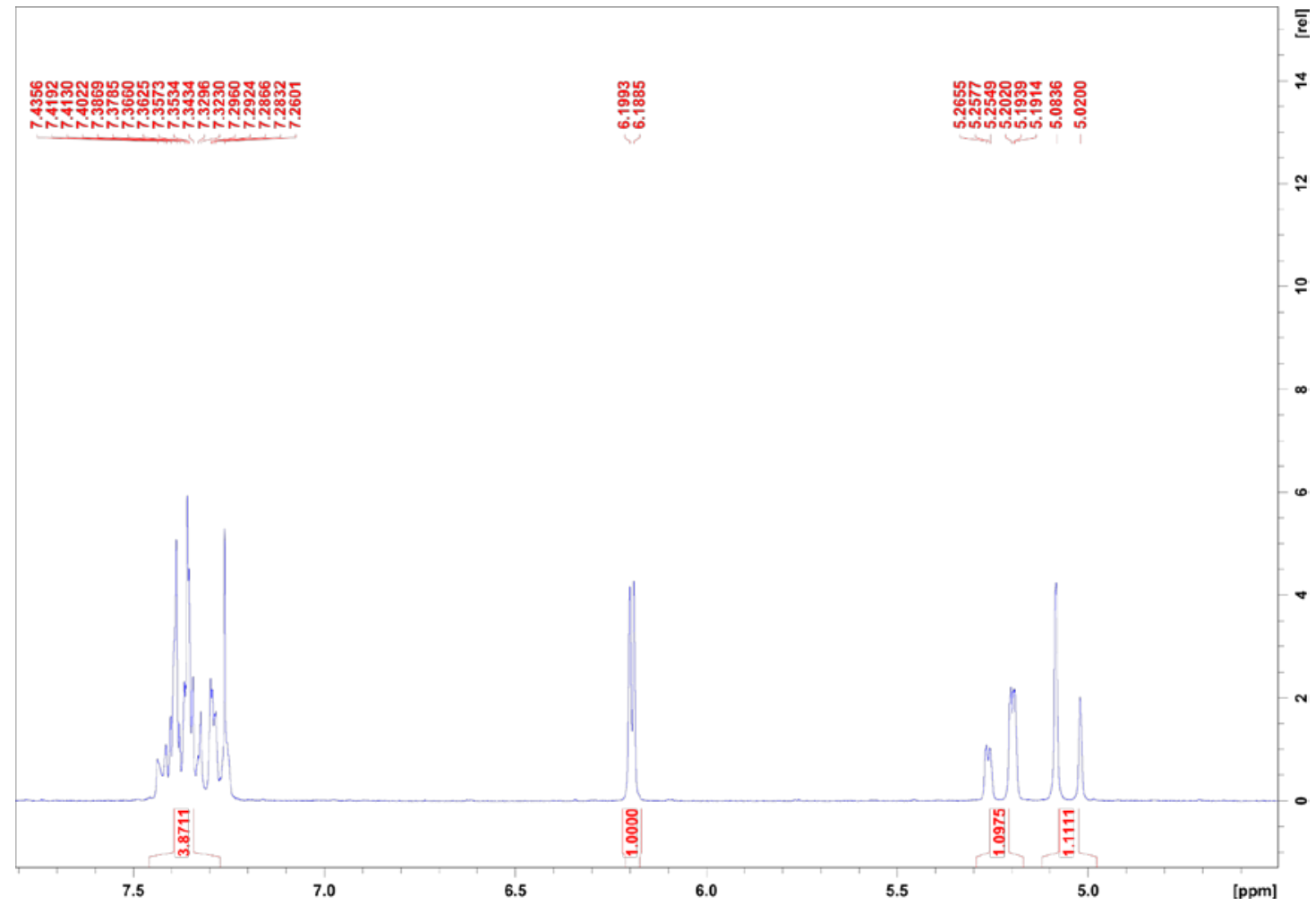

Fig. S75b Zoom of ${ }^{1} \mathrm{H}$ NMR of 1,3-Dihydro-1-methoxyisobenzofuran in $\mathrm{CDCl}_{3}$. 


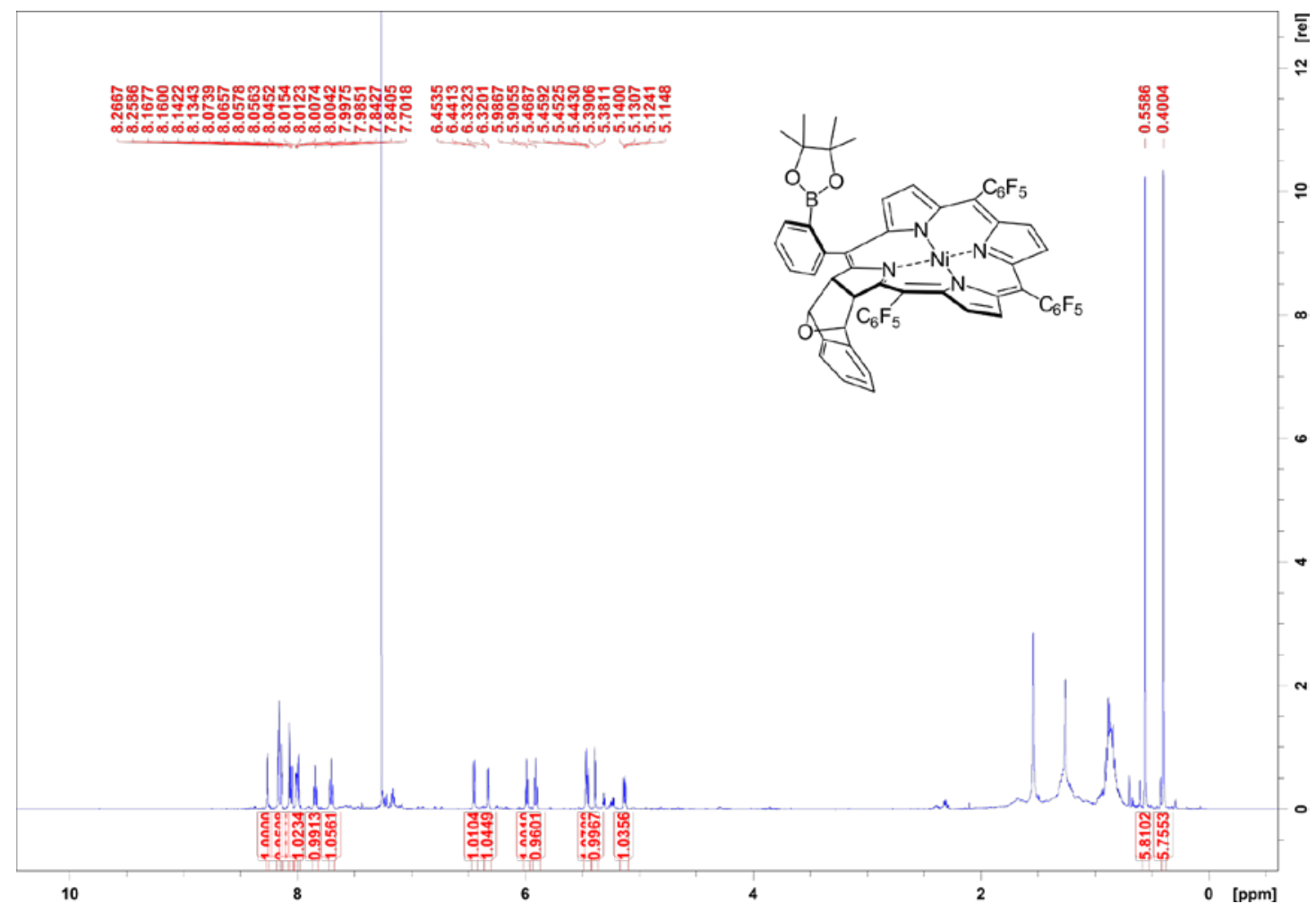

Fig. S76a ${ }^{1} \mathrm{H}$ NMR of 5-(Phenyl-2'-(boronic acid pinacol ester))-10,15,20-tris(pentafluorophenyl)$\mathrm{Ni}(\mathrm{II})$ chlorin 6a-Ni in $\mathrm{CDCl}_{3}$.

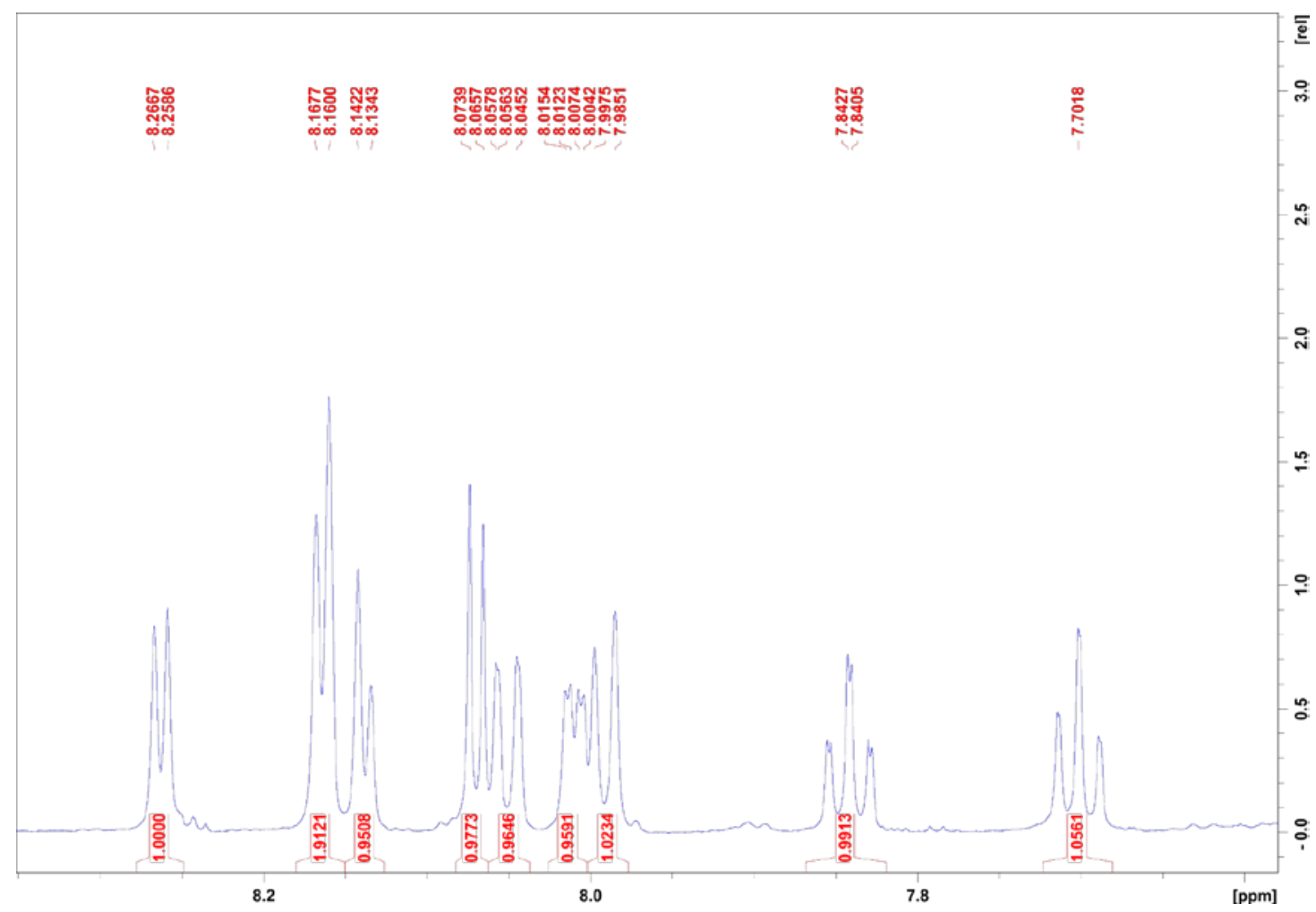

Fig. S76b Zoom of ${ }^{1} \mathrm{H} \quad$ NMR of 5-(Phenyl-2'-(boronic acid pinacol ester))-10,15,20tris(pentafluorophenyl)-Ni(II)chlorin 6a-Ni in $\mathrm{CDCl}_{3}$. 


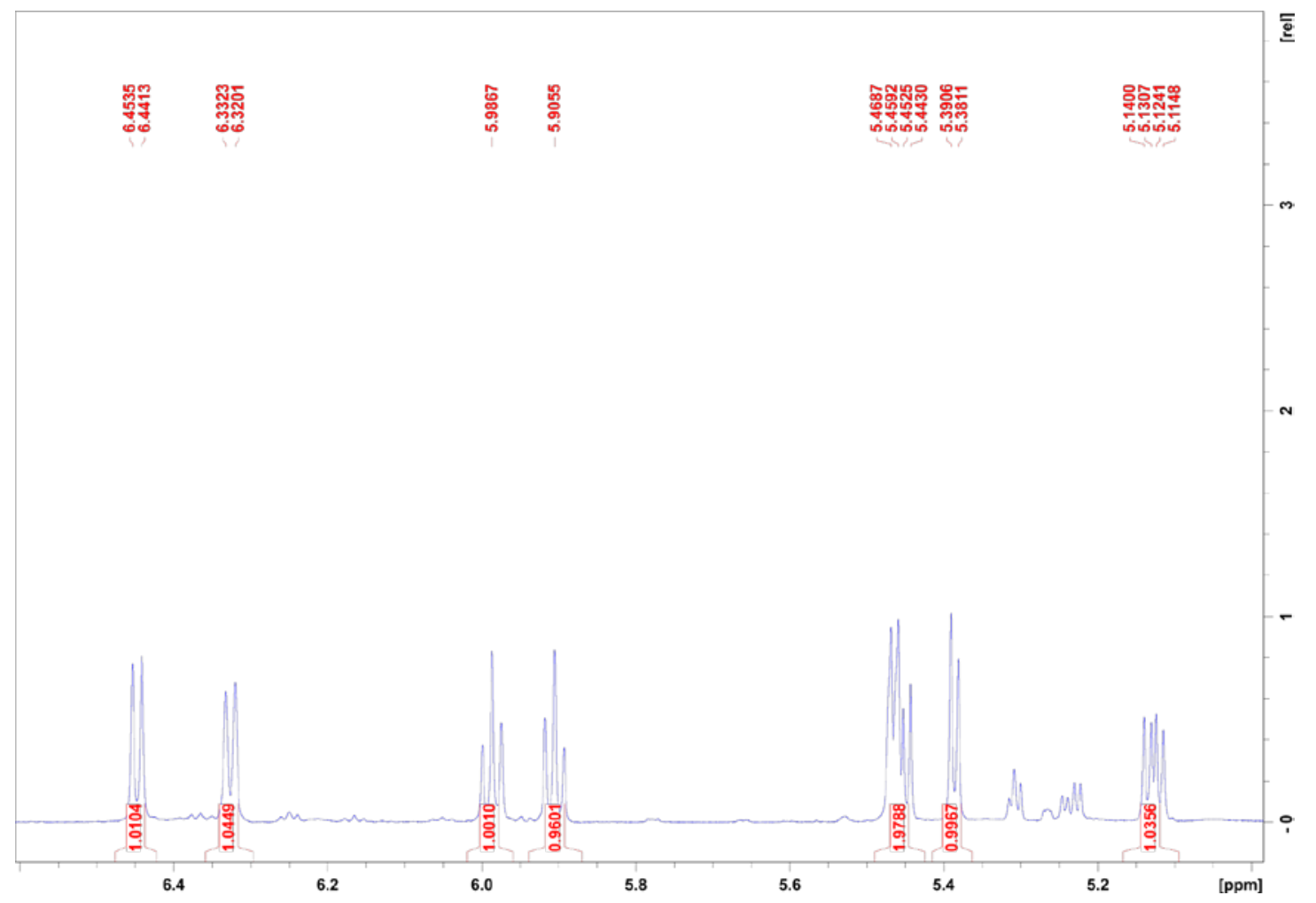

Fig. S76c Zoom of ${ }^{1} \mathrm{H} \quad$ NMR of 5-(Phenyl-2'-(boronic acid pinacol ester))-10,15,20tris(pentafluorophenyl)-Ni(II)chlorin $\mathbf{6 a - N i}$ in $\mathrm{CDCl}_{3}$.

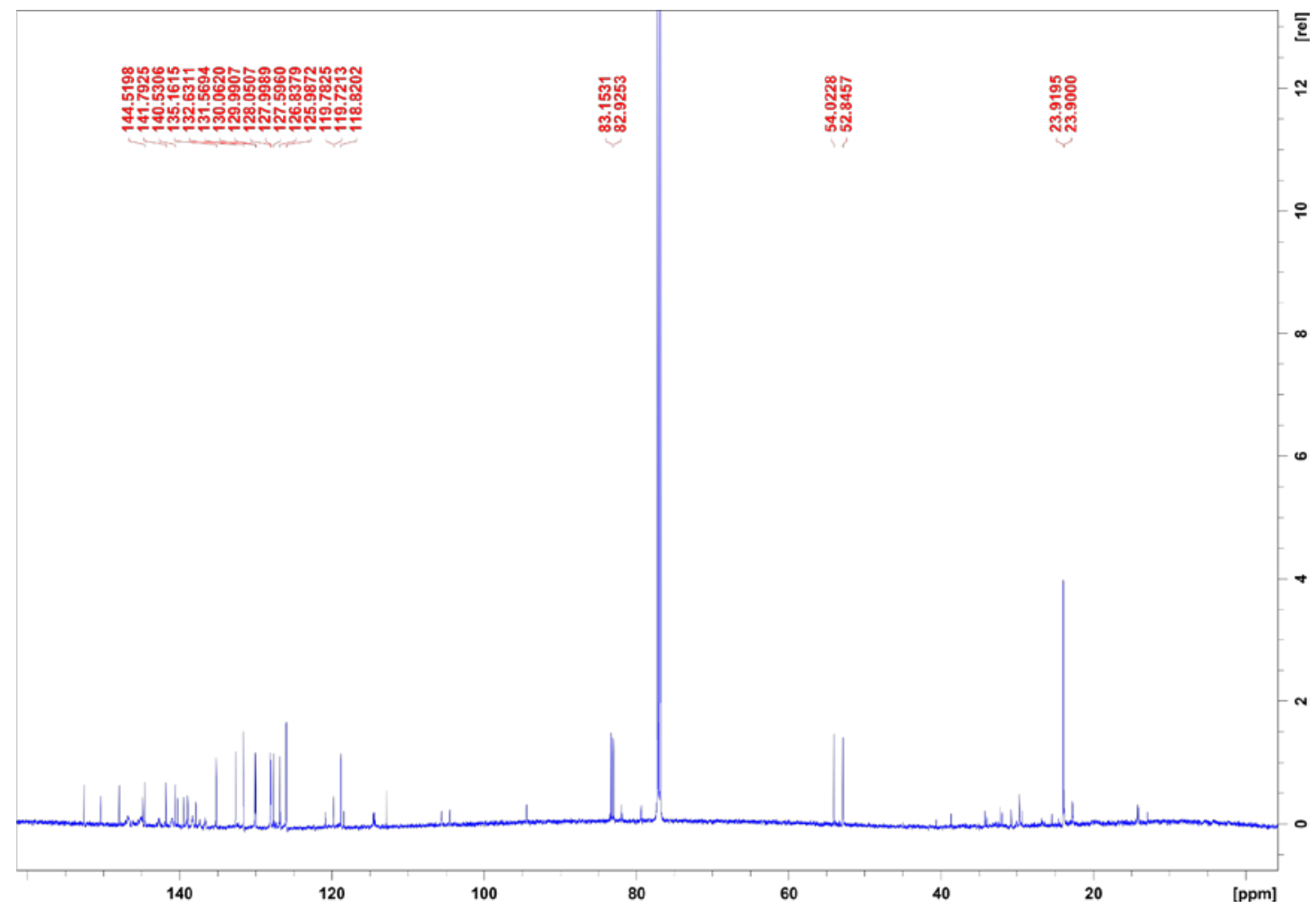

Fig. S76d ${ }^{13} \mathrm{C}$ NMR of 5-(Phenyl-2'-(boronic acid pinacol ester))-10,15,20-tris(pentafluorophenyl)$\mathrm{Ni}(\mathrm{II})$ chlorin 6a-Ni in $\mathrm{CDCl}_{3}$. 


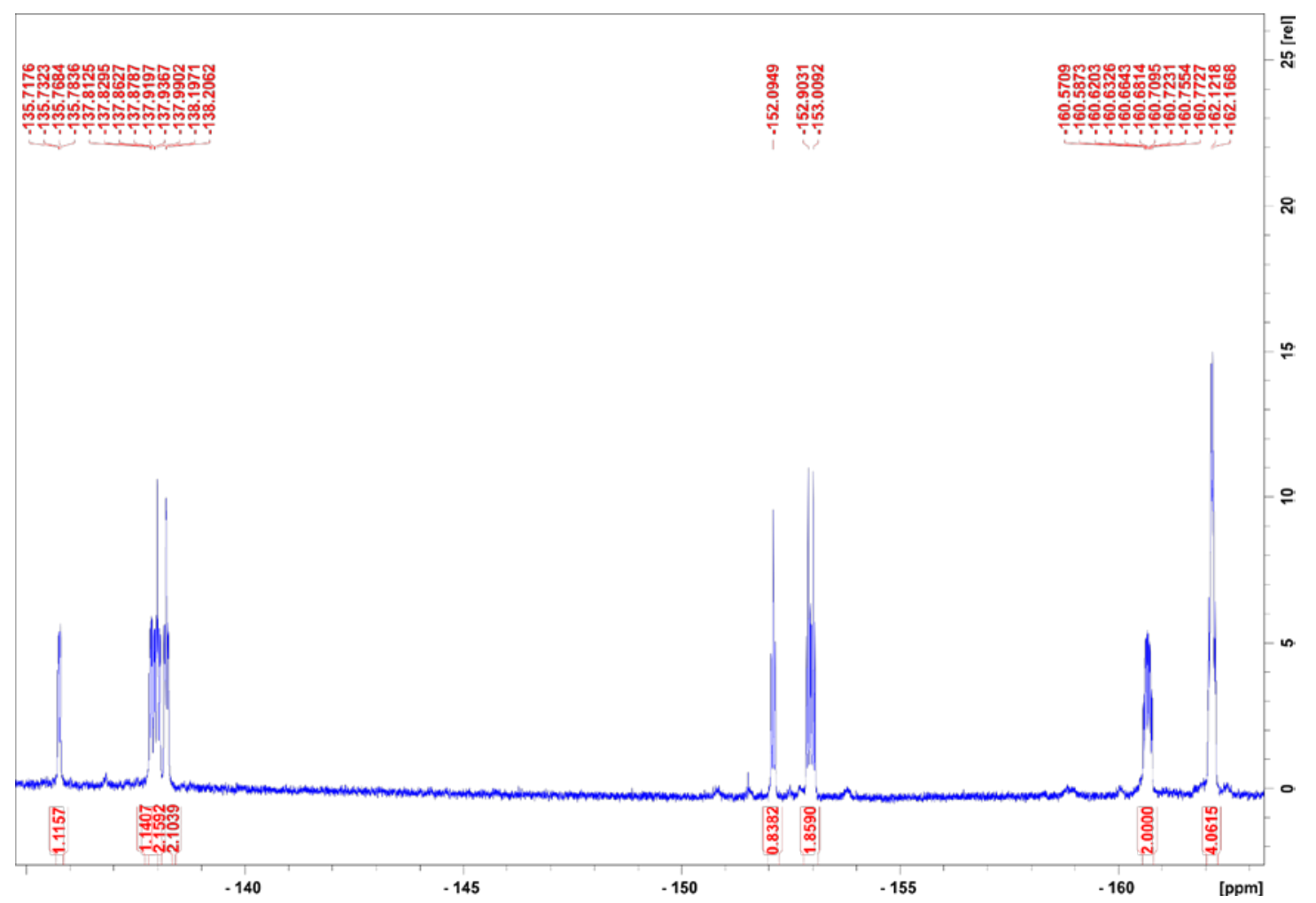

Fig. S76e ${ }^{19} \mathrm{~F}$ NMR of 5-(Phenyl-2'-(boronic acid pinacol ester))-10,15,20-tris(pentafluorophenyl)$\mathrm{Ni}(\mathrm{II})$ chlorin 6a-Ni in $\mathrm{CDCl}_{3}$.

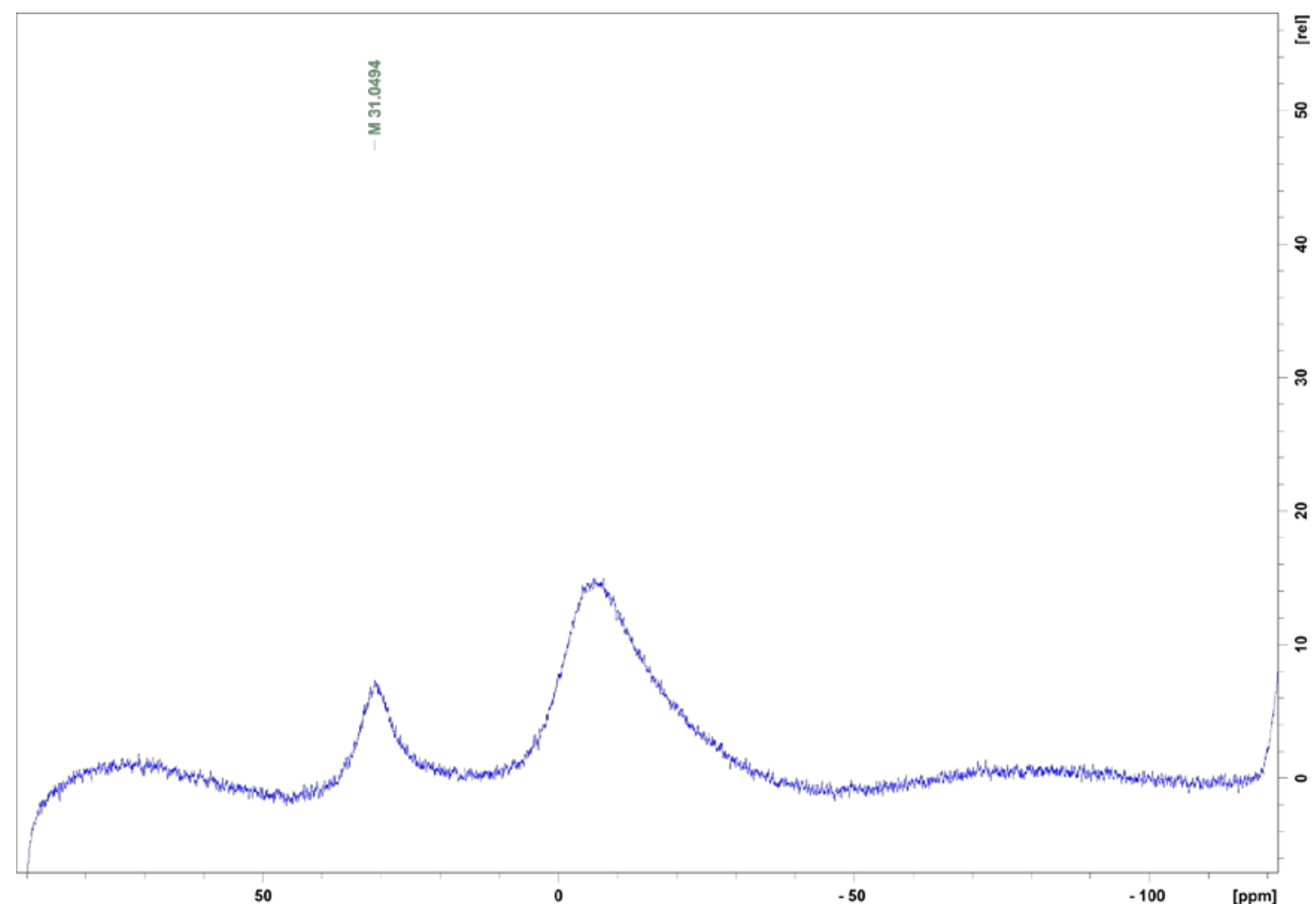

Fig. S76f ${ }^{11} \mathrm{~B}$ NMR of 5-(Phenyl-2'-(boronic acid pinacol ester))-10,15,20-tris(pentafluorophenyl)$\mathrm{Ni}(\mathrm{II})$ chlorin $\mathbf{6 a}-\mathrm{Ni}$ in $\mathrm{CDCl}_{3}$. 


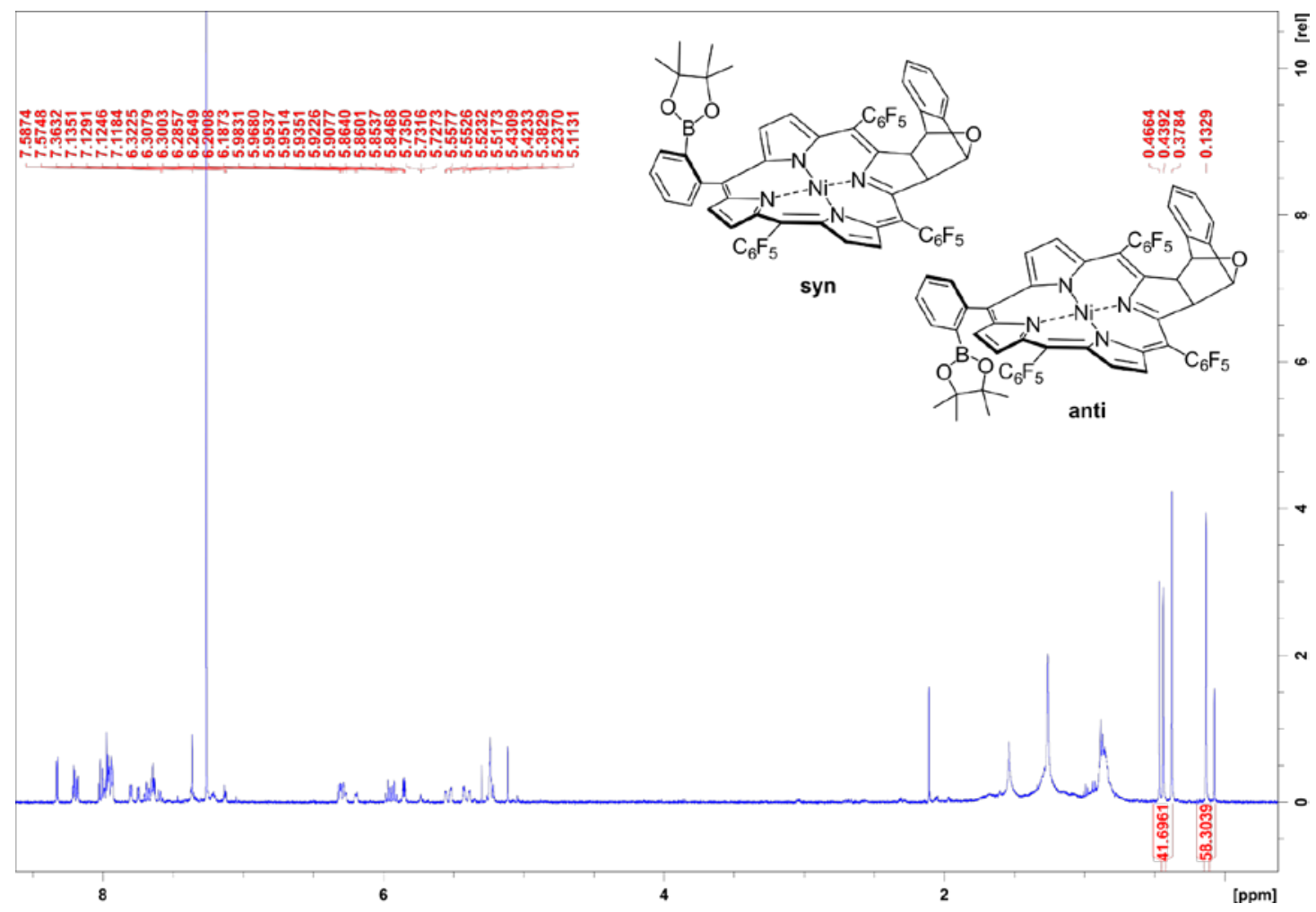

Fig. S77a ${ }^{1} \mathrm{H}$ NMR of 5-(Phenyl-2'-(boronic acid pinacol ester))-10,15,20-tris(pentafluorophenyl)$\mathrm{Ni}(\mathrm{II})$ chlorin $\mathbf{6 b}-\mathrm{Ni}$ in $\mathrm{CDCl}_{3}$ (mixture of syn and anti isomer (42:58)).

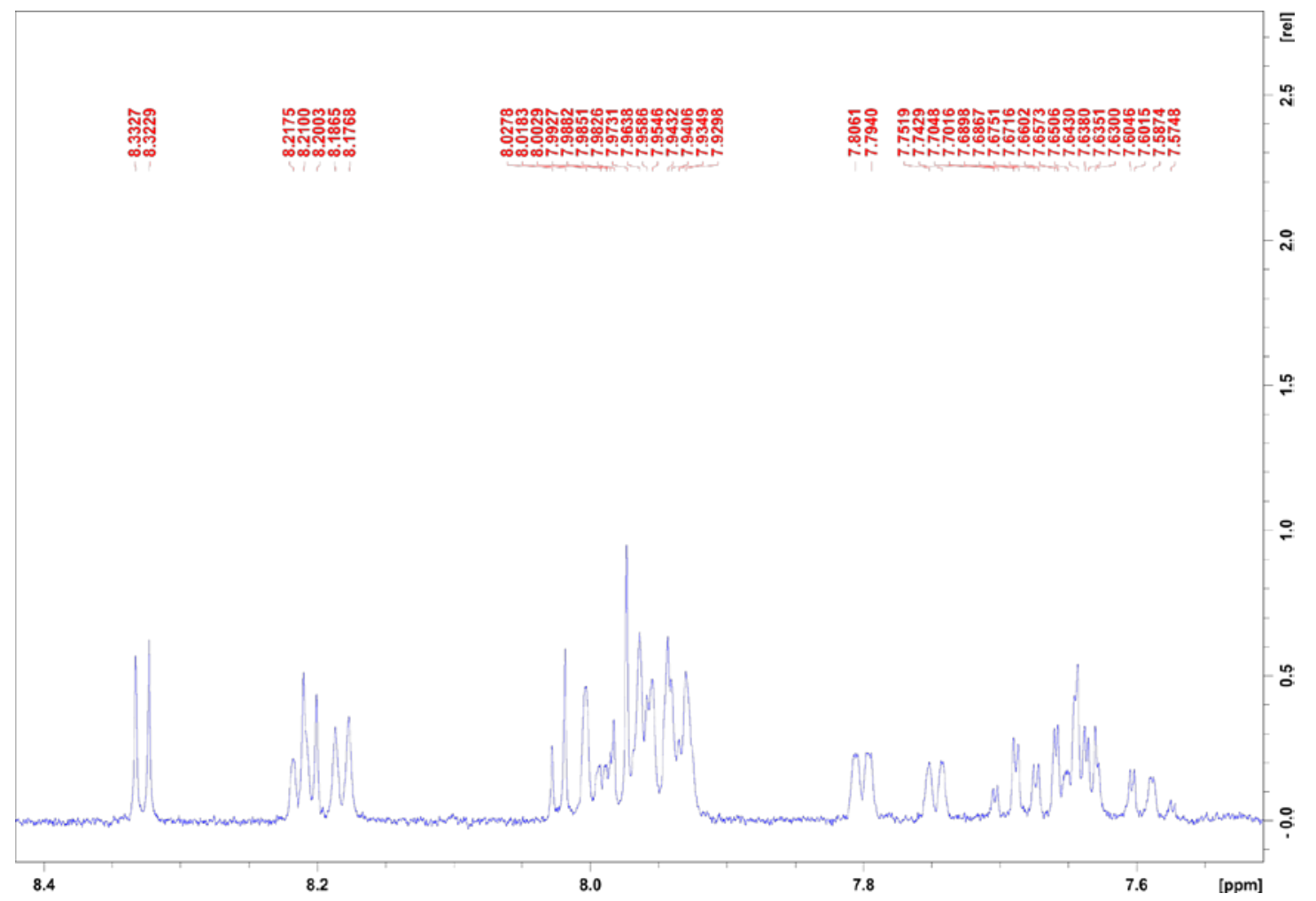

Fig. S77b Zoom of ${ }^{1} \mathrm{H} \quad$ NMR of 5 -(Phenyl-2'-(boronic acid pinacol ester))-10,15,20tris(pentafluorophenyl)-Ni(II)chlorin $\mathbf{6 b}-\mathbf{N i}$ in $\mathrm{CDCl}_{3}$ (mixture of syn and anti isomer (42:58)). 


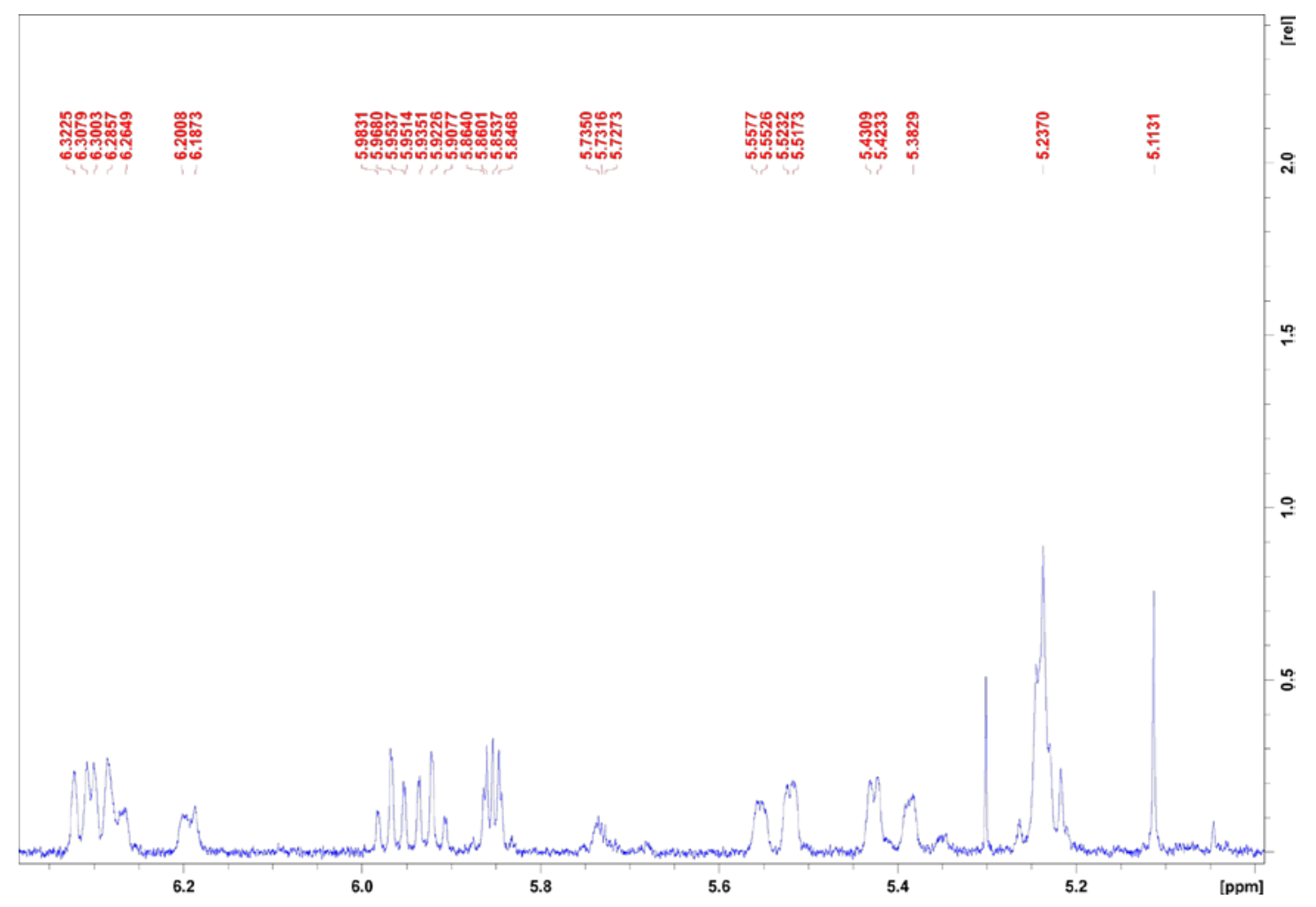

Fig. S77c Zoom of ${ }^{1} \mathrm{H} \quad$ NMR of 5-(Phenyl-2'-(boronic acid pinacol ester))-10,15,20tris(pentafluorophenyl)-Ni(II)chlorin $\mathbf{6 b}-\mathbf{N i}$ in $\mathrm{CDCl}_{3}$ (mixture of syn and anti isomer (42:58)).

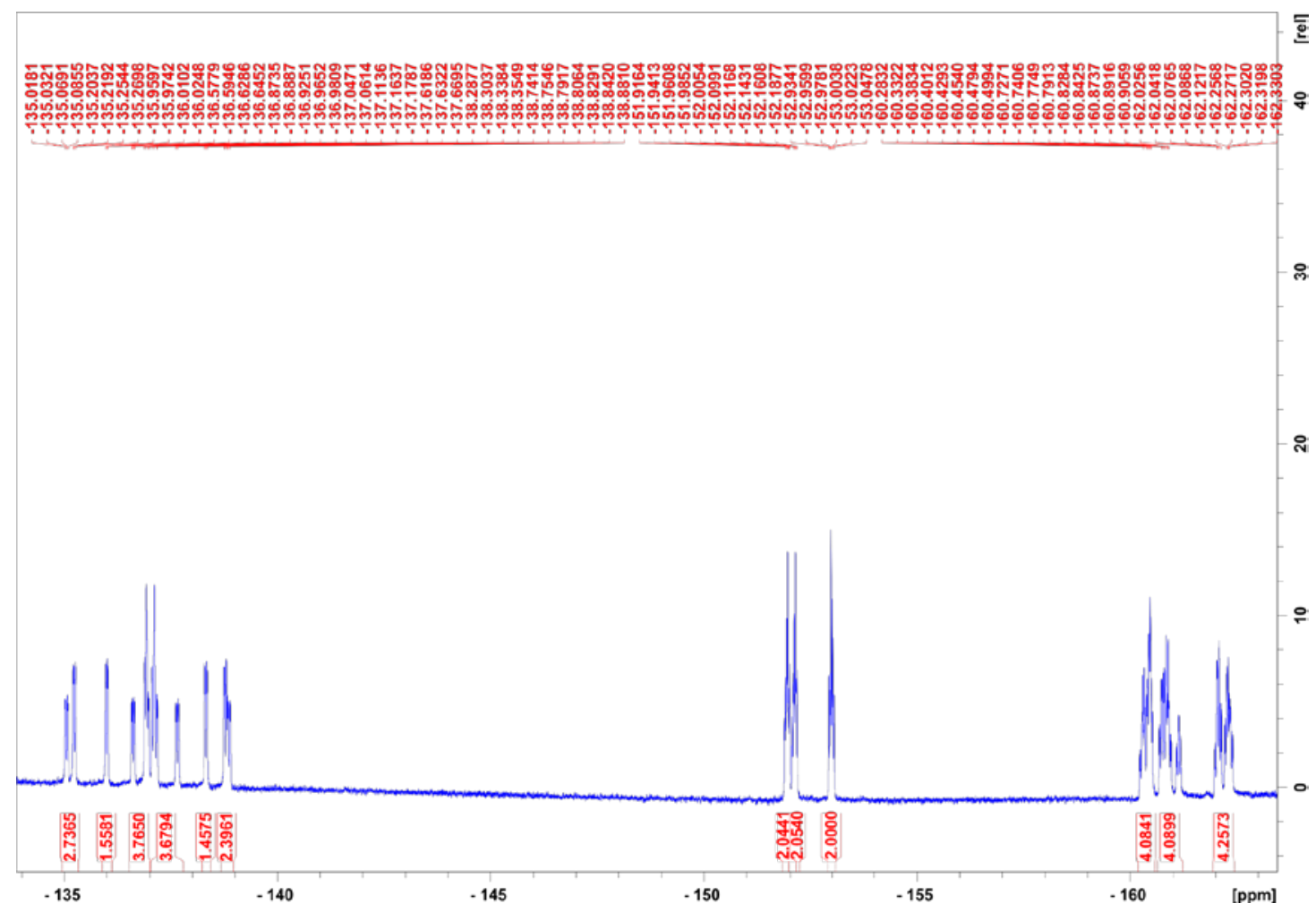

Fig. S77d ${ }^{19}$ F NMR of 5-(Phenyl-2'-(boronic acid pinacol ester))-10,15,20-tris(pentafluorophenyl)$\mathrm{Ni}(\mathrm{II})$ chlorin $\mathbf{6 b}-\mathbf{N i}$ in $\mathrm{CDCl}_{3}$ (mixture of syn and anti isomer (42:58)). 


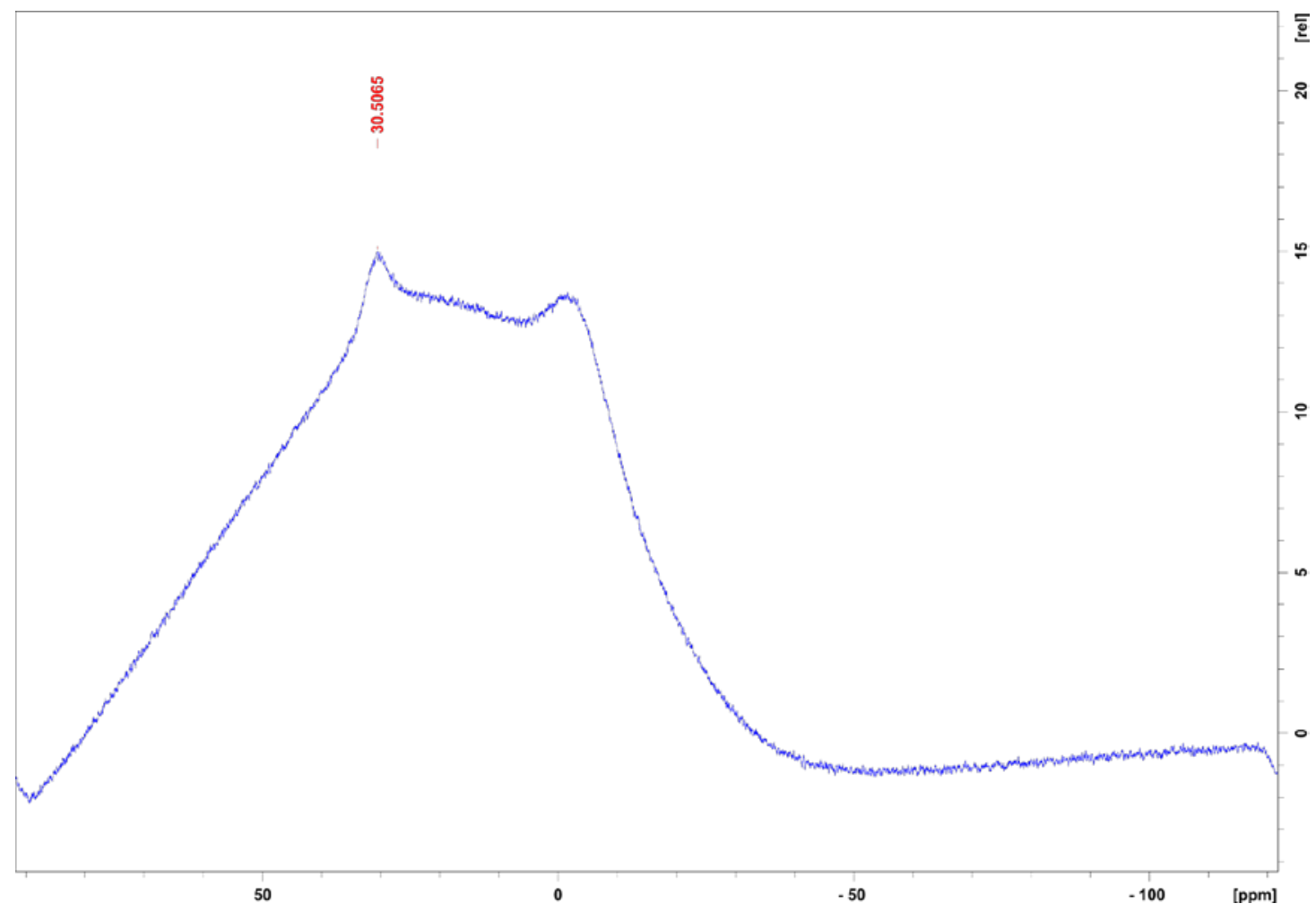

Fig. S77e ${ }^{11}$ B NMR of 5-(Phenyl-2'-(boronic acid pinacol ester))-10,15,20-tris(pentafluorophenyl)$\mathrm{Ni}(\mathrm{II})$ chlorin $\mathbf{6 b}-\mathrm{Ni}$ in $\mathrm{CDCl}_{3}$ (mixture of syn and anti isomer (42:58)).

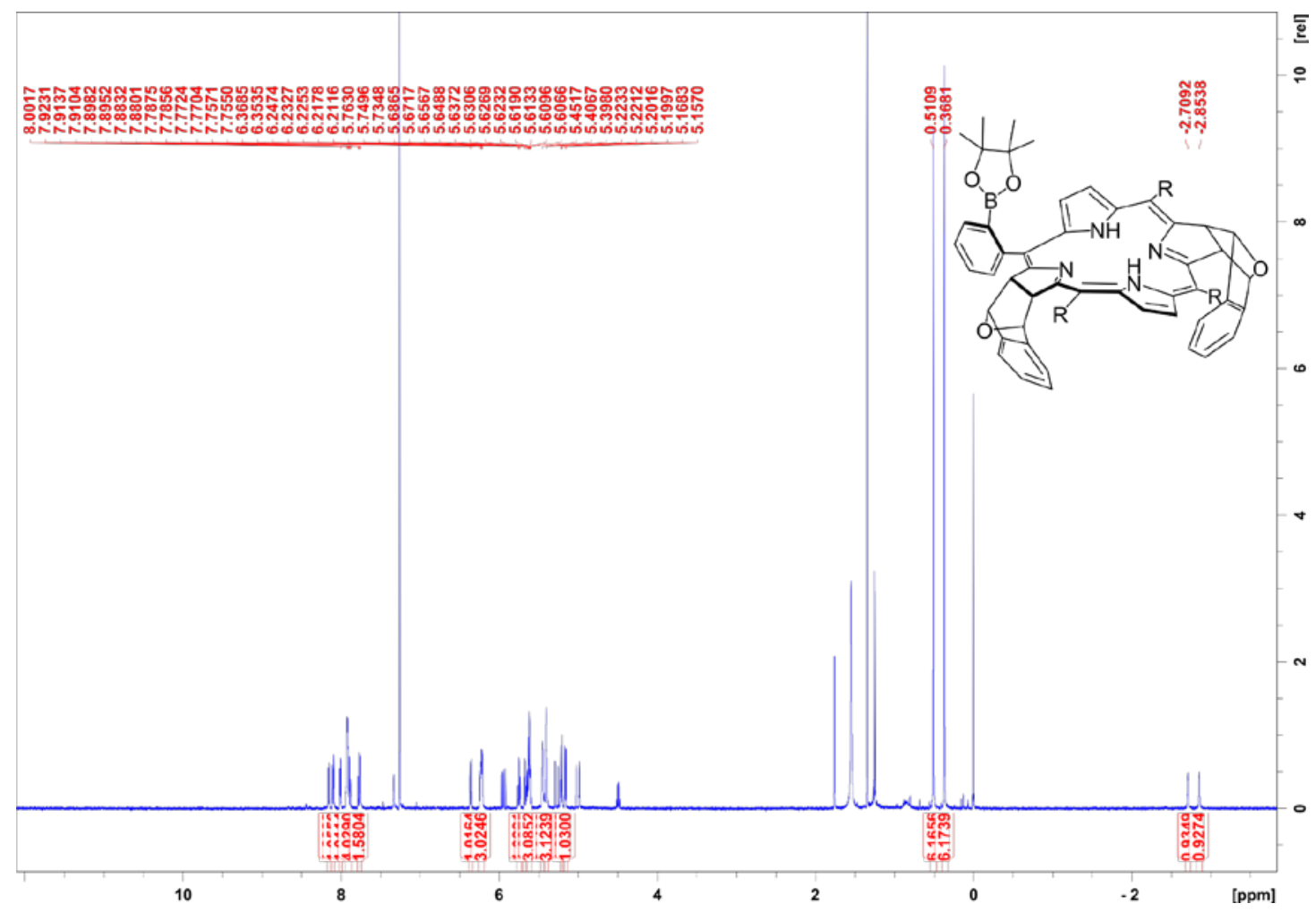

Fig. S78a ${ }^{1} \mathrm{H}$ NMR of 5-(Phenyl-2'-(boronic acid pinacol ester))-10,15,20-tris(pentafluorophenyl)bacteriochlorin 7- $\mathrm{H}_{2}$ in $\mathrm{CDCl}_{3}\left(\mathrm{R}=\mathrm{C}_{6} \mathrm{~F}_{5}\right)$. 


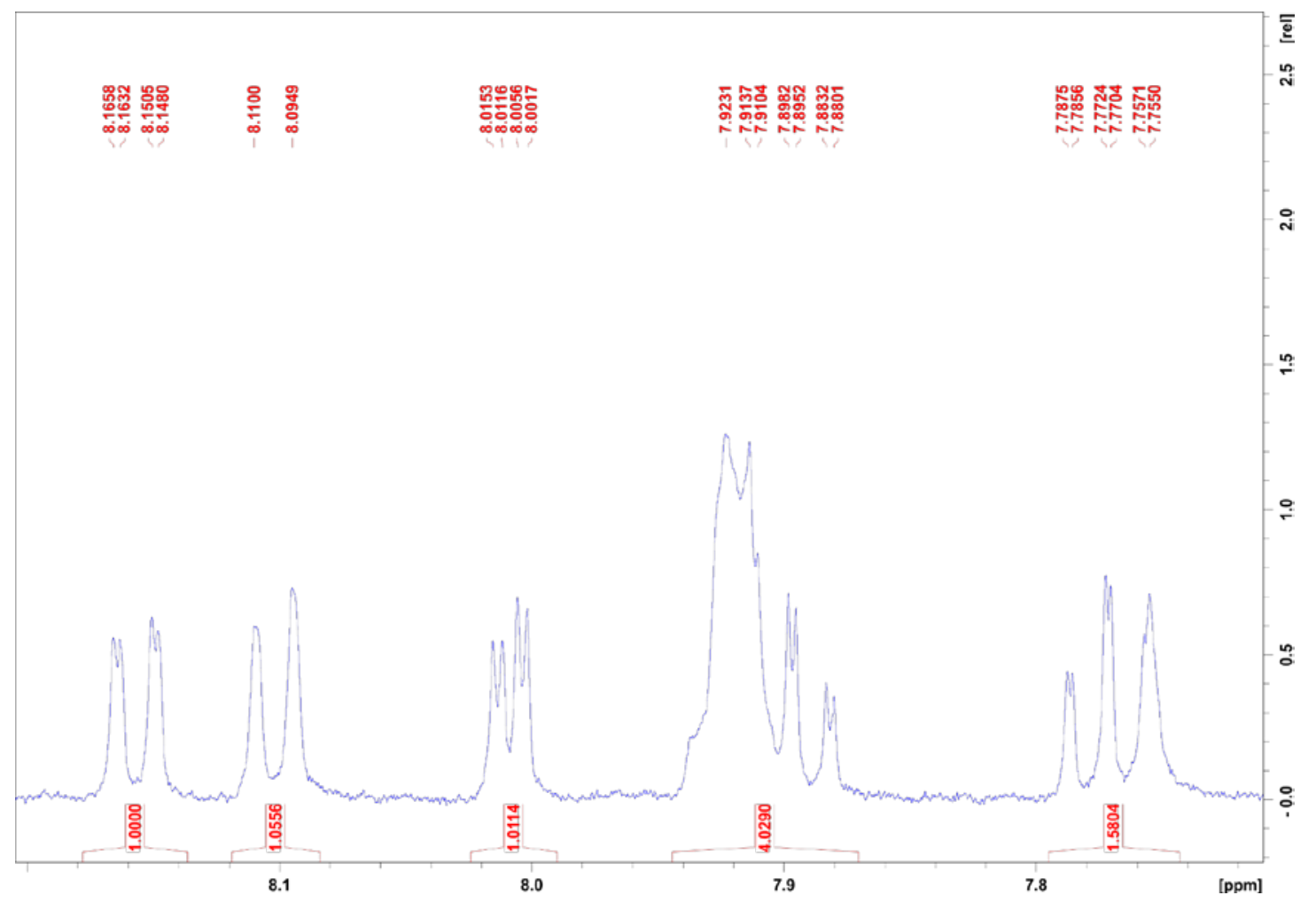

Fig. S78b Zoom of ${ }^{1} \mathrm{H} \quad$ NMR of 5-(Phenyl-2'-(boronic acid pinacol ester))-10,15,20tris(pentafluorophenyl)- bacteriochlorin $\mathbf{7}-\mathbf{H}_{2}$ in $\mathrm{CDCl}_{3}$.

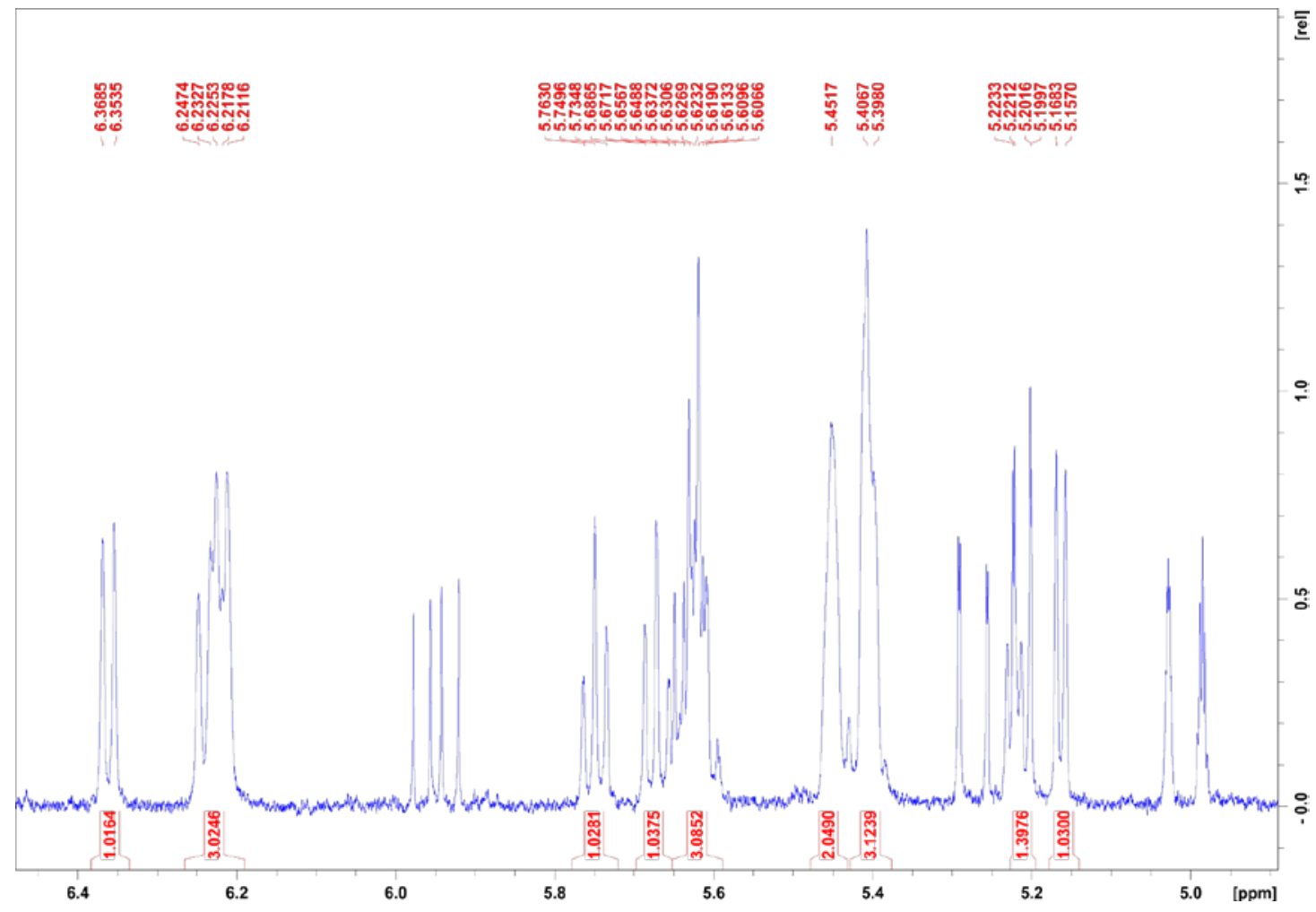

Fig. S78c Zoom of ${ }^{1} \mathrm{H} \quad$ NMR of 5-(Phenyl-2'-(boronic acid pinacol ester))-10,15,20tris(pentafluorophenyl)- bacteriochlorin $\mathbf{7 - \mathbf { H } _ { 2 }}$ in $\mathrm{CDCl}_{3}$. 


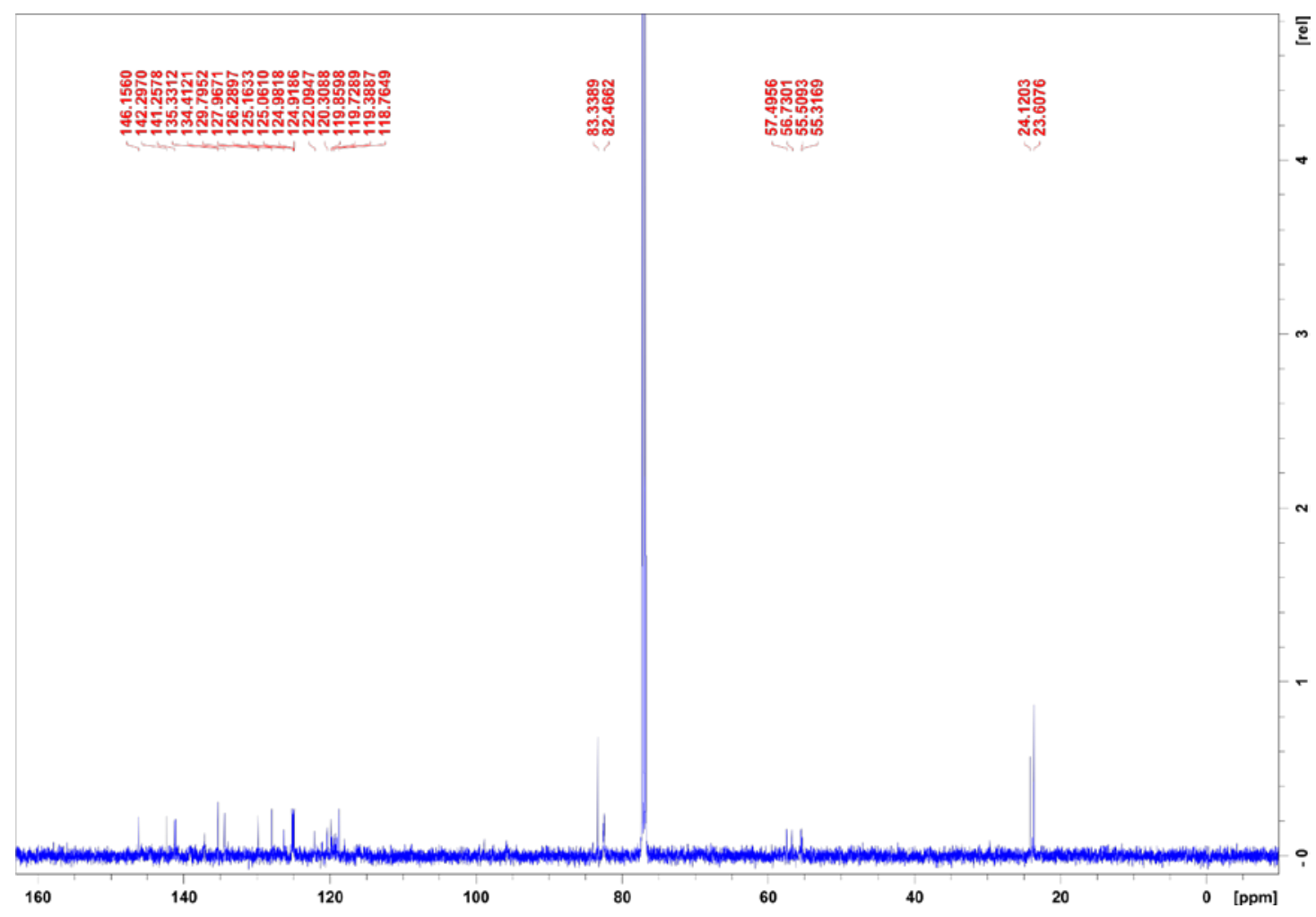

Fig. S78d ${ }^{13} \mathrm{C}$ NMR of 5-(Phenyl-2'-(boronic acid pinacol ester))-10,15,20-tris(pentafluorophenyl)bacteriochlorin $\mathbf{7}-\mathbf{H}_{2}$ in $\mathrm{CDCl}_{3}$.

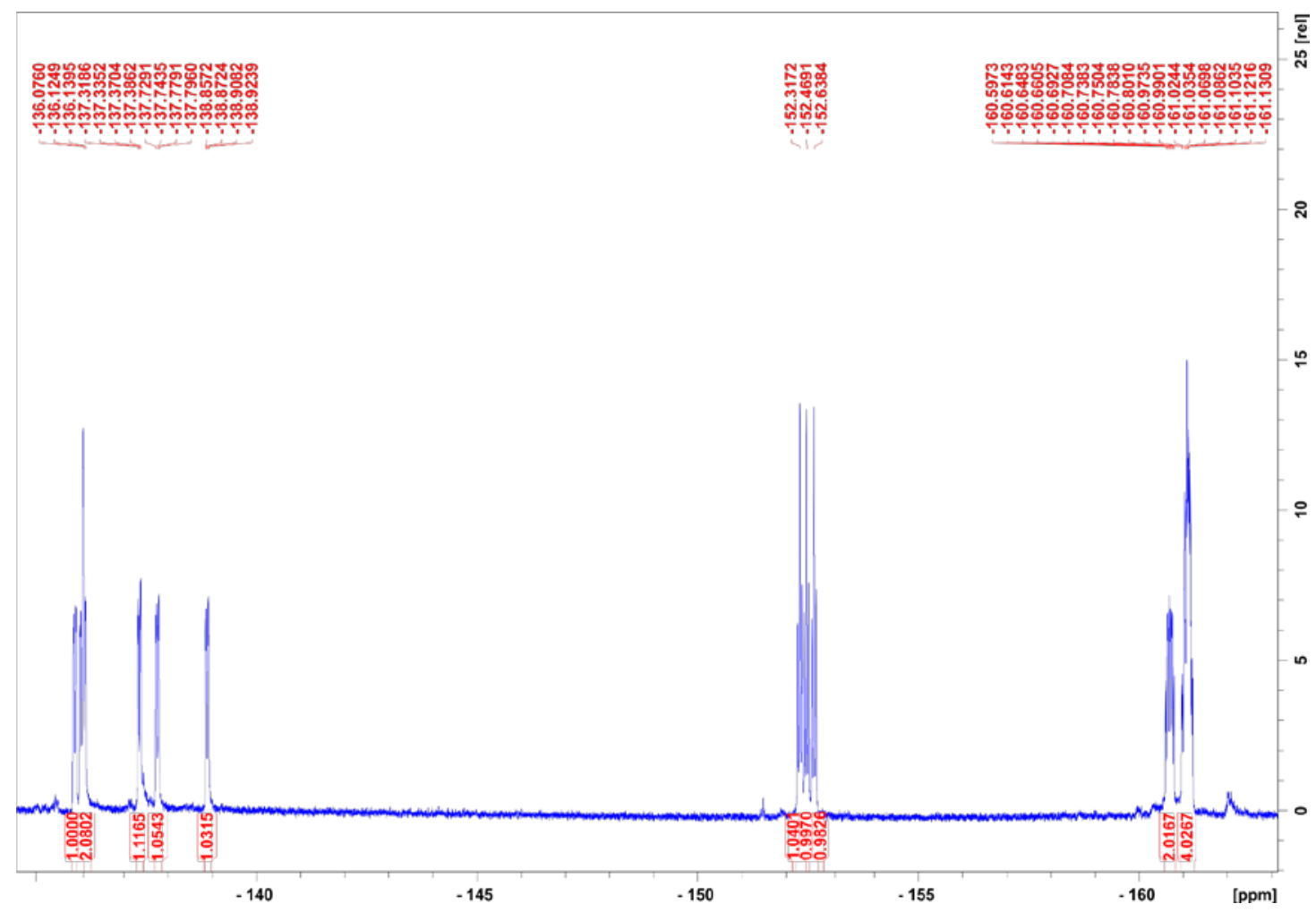

Fig. S78e ${ }^{19} \mathrm{~F}$ NMR of 5-(Phenyl-2'-(boronic acid pinacol ester))-10,15,20-tris(pentafluorophenyl)bacteriochlorin $\mathbf{7}-\mathbf{H}_{2}$ in $\mathrm{CDCl}_{3}$. 


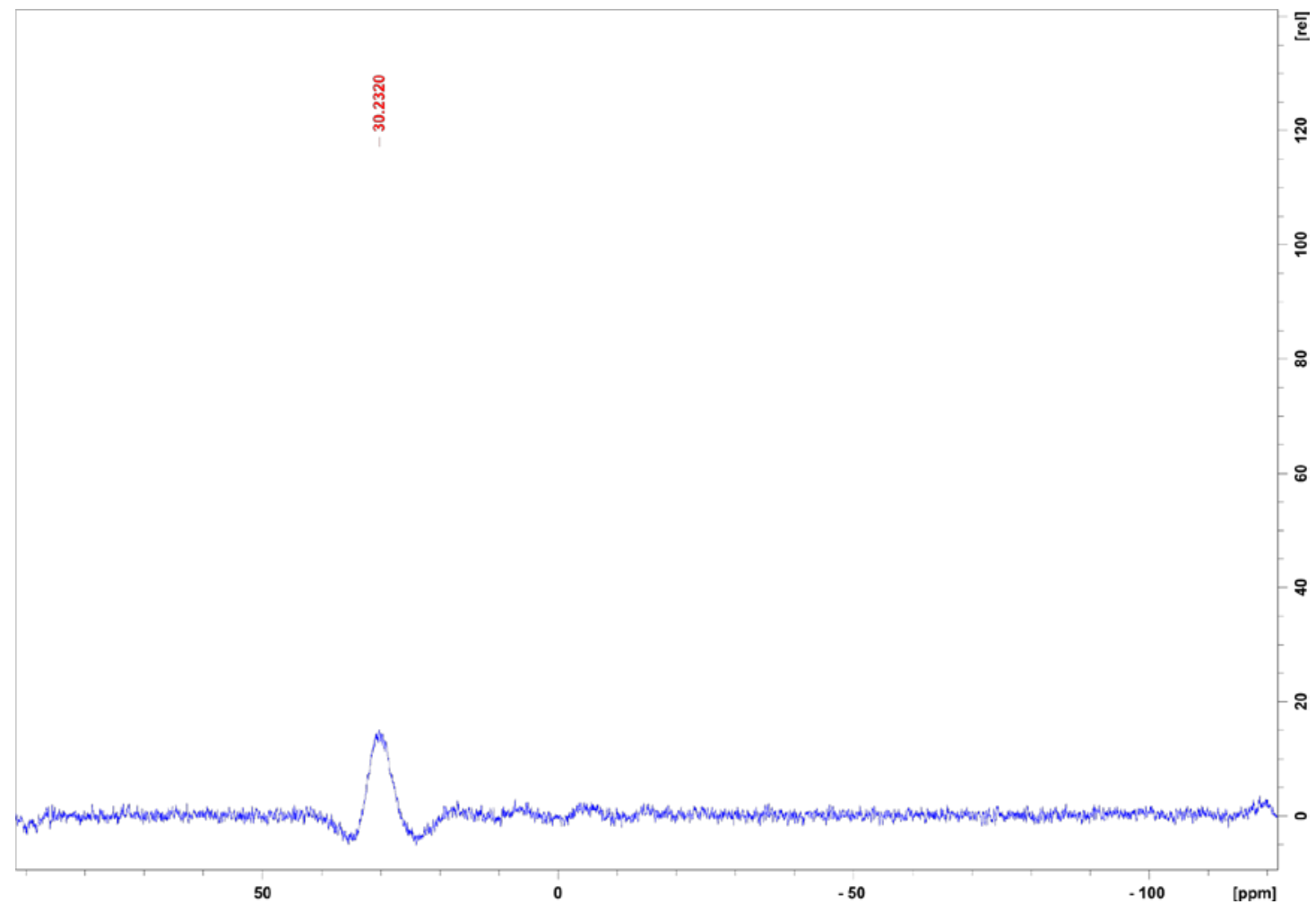

Fig. S78f ${ }^{11} \mathrm{~B}$ NMR of 5-(Phenyl-2'-(boronic acid pinacol ester))-10,15,20-tris(pentafluorophenyl)bacteriochlorin $\mathbf{7}-\mathbf{H}_{2}$ in $\mathrm{CDCl}_{3}$.

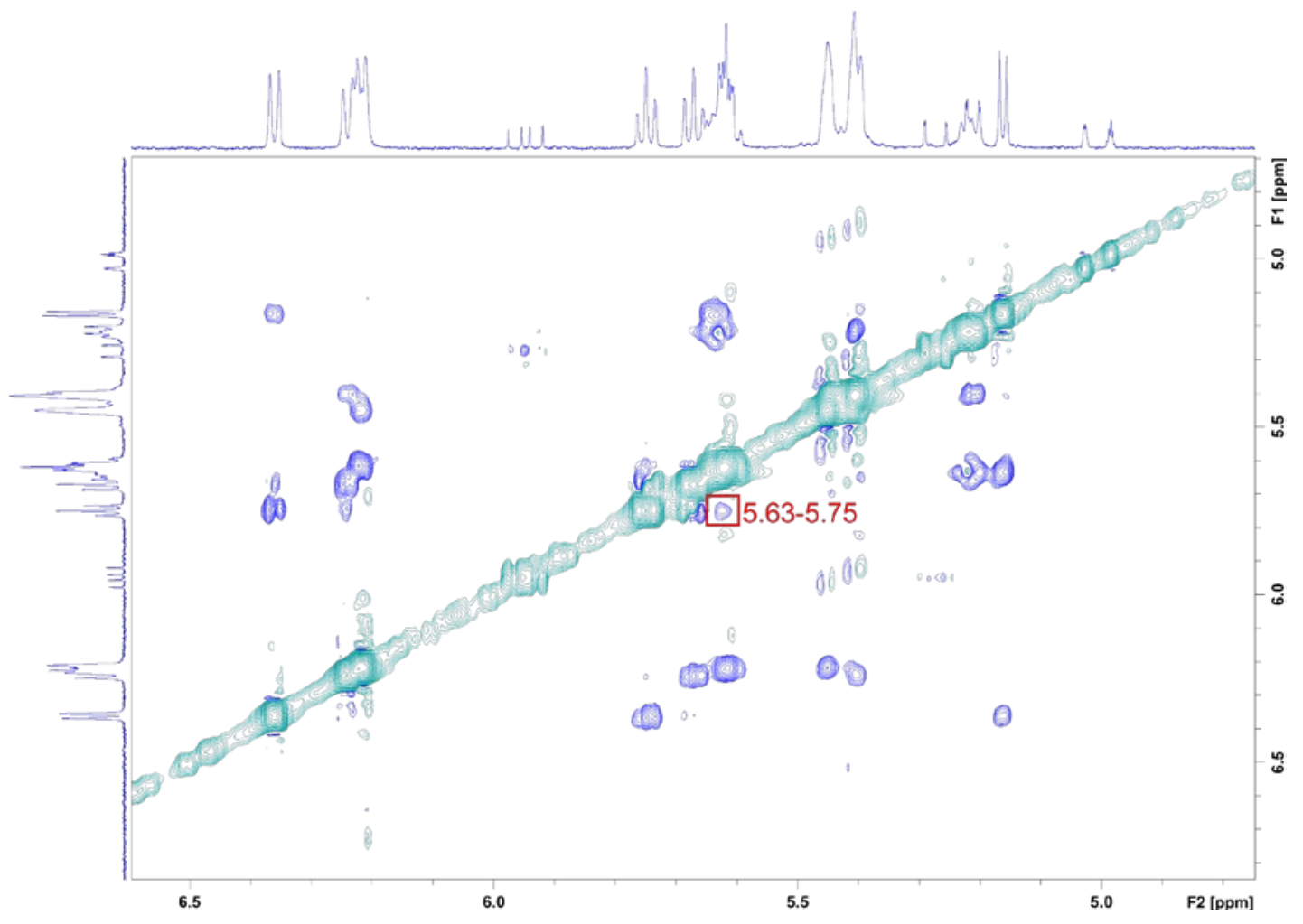

Fig. S78g $\quad{ }^{1} \mathrm{H} \quad$ NOESY NMR of 5-(Phenyl-2'-(boronic acid pinacol ester))-10,15,20tris(pentafluorophenyl)bacteriochlorin $\mathbf{7}-\mathbf{H}_{2}$ in $\mathrm{CDCl}_{3}$. The signal in the red square proves the syn orientation of the isobenzofuran rings. 


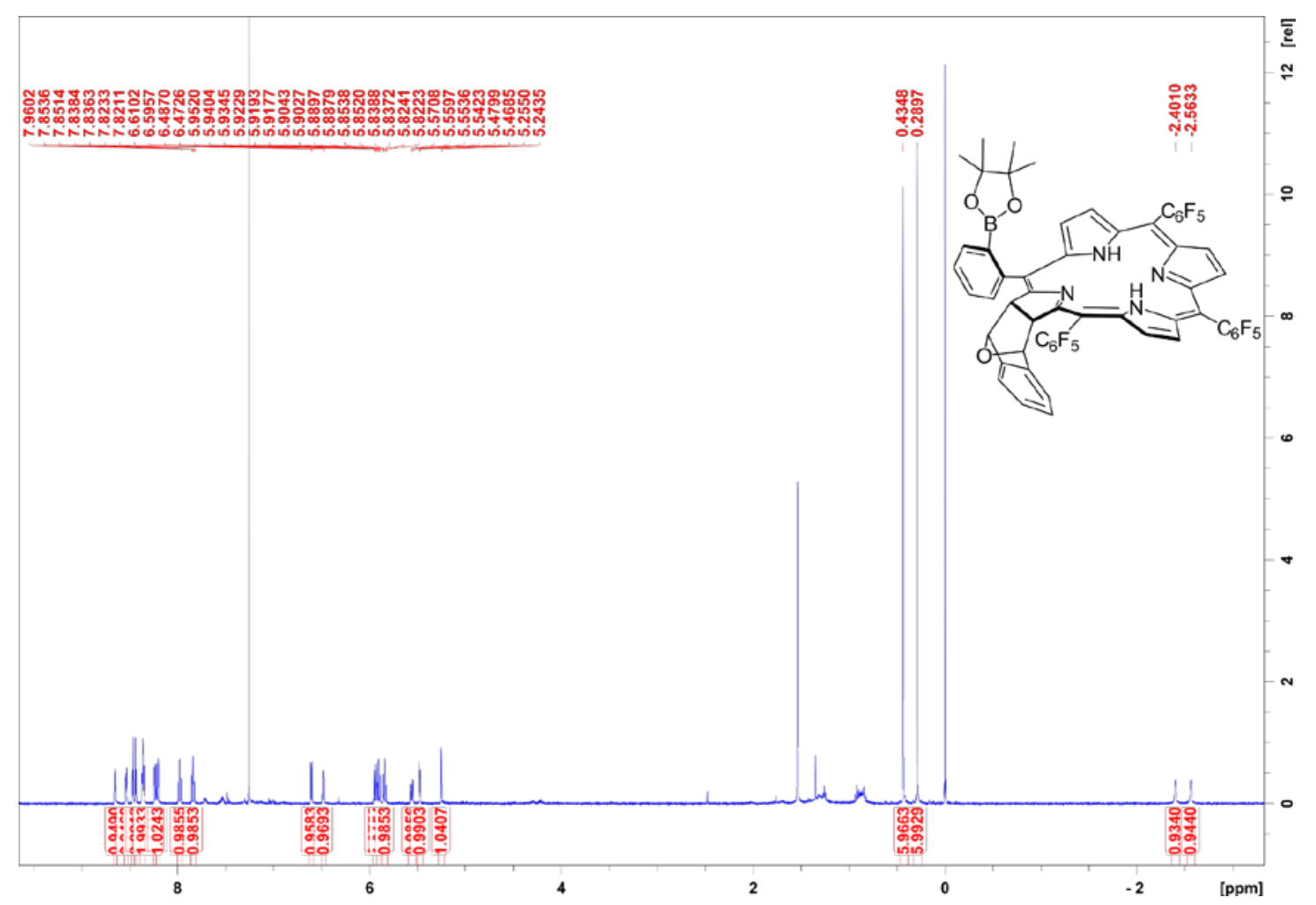

Fig. S79a ${ }^{1} \mathrm{H}$ NMR of 5-(Phenyl-2'-(boronic acid pinacol ester))-10,15,20-tris(pentafluorophenyl)chlorin $\mathbf{6 a}-\mathbf{H}_{2}$ in $\mathrm{CDCl}_{3}$.

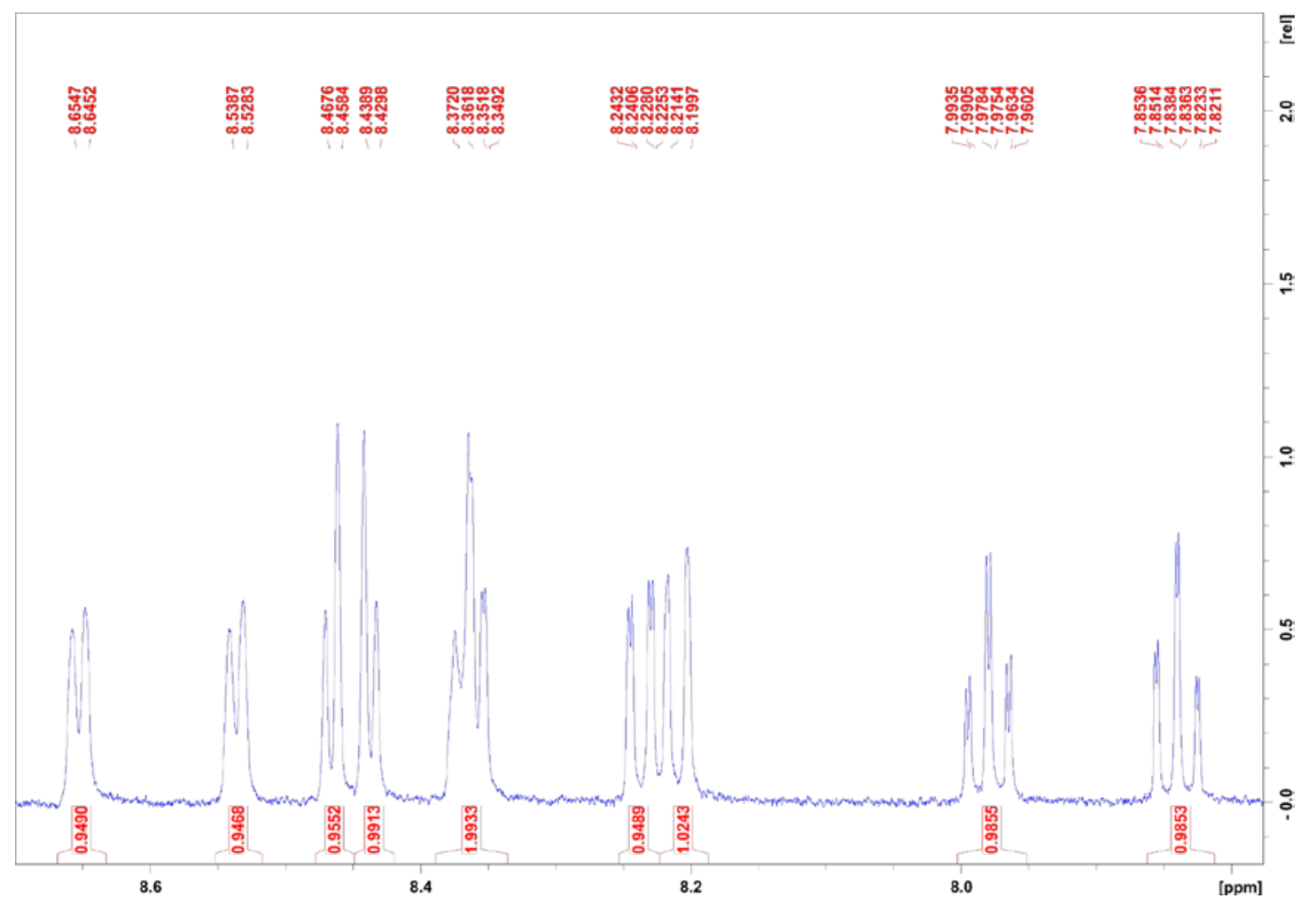

Fig. S79b Zoom of ${ }^{1} \mathrm{H} \quad$ NMR of 5-(Phenyl-2'-(boronic acid pinacol ester))-10,15,20tris(pentafluorophenyl)- chlorin $\mathbf{6 a - \mathbf { H } _ { 2 }}$ in $\mathrm{CDCl}_{3}$. 


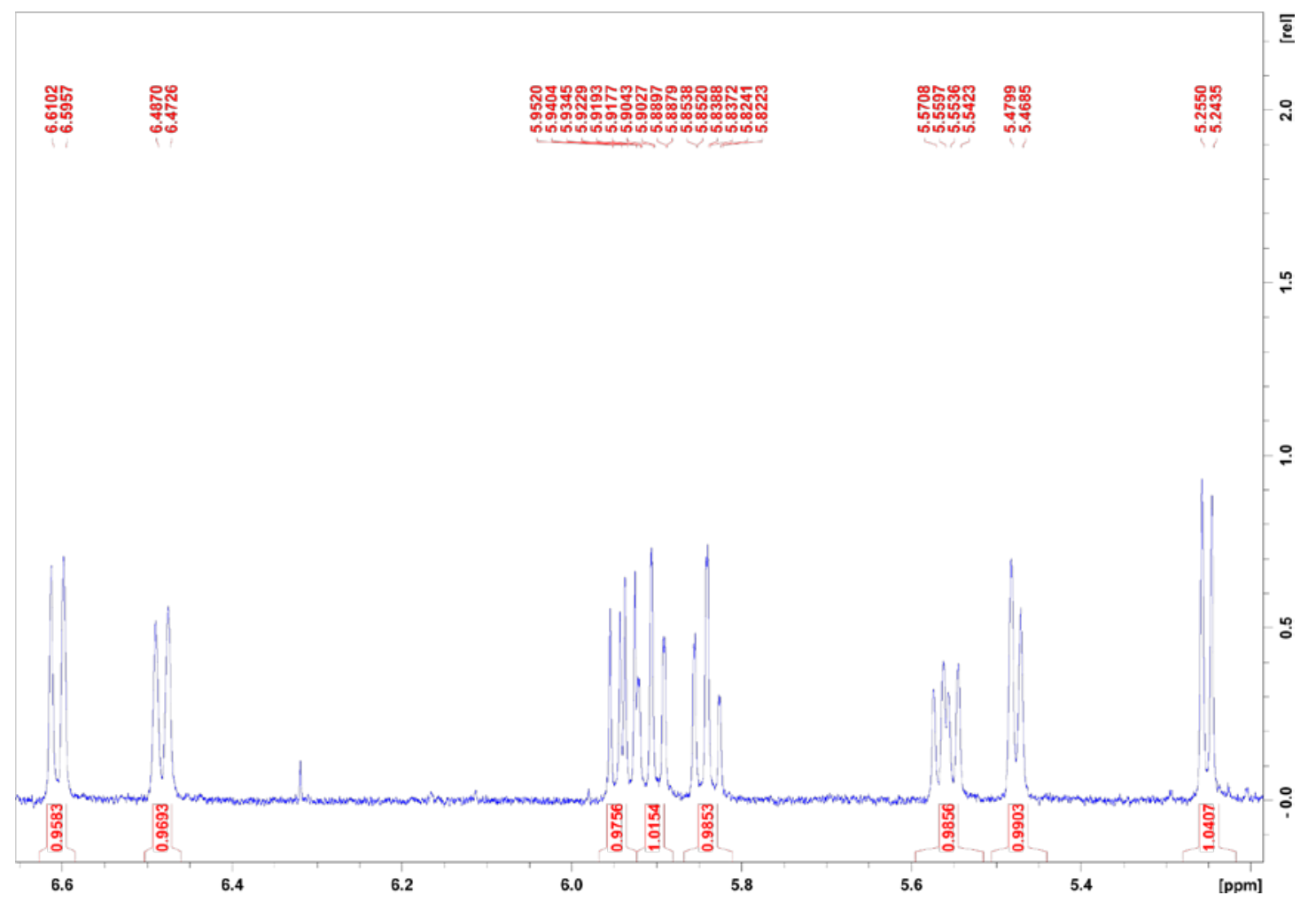

Fig. S79c Zoom of ${ }^{1} \mathrm{H} \quad$ NMR of 5-(Phenyl-2'-(boronic acid pinacol ester))-10,15,20tris(pentafluorophenyl)- chlorin $\mathbf{6 a}-\mathbf{H}_{2}$ in $\mathrm{CDCl}_{3}$.

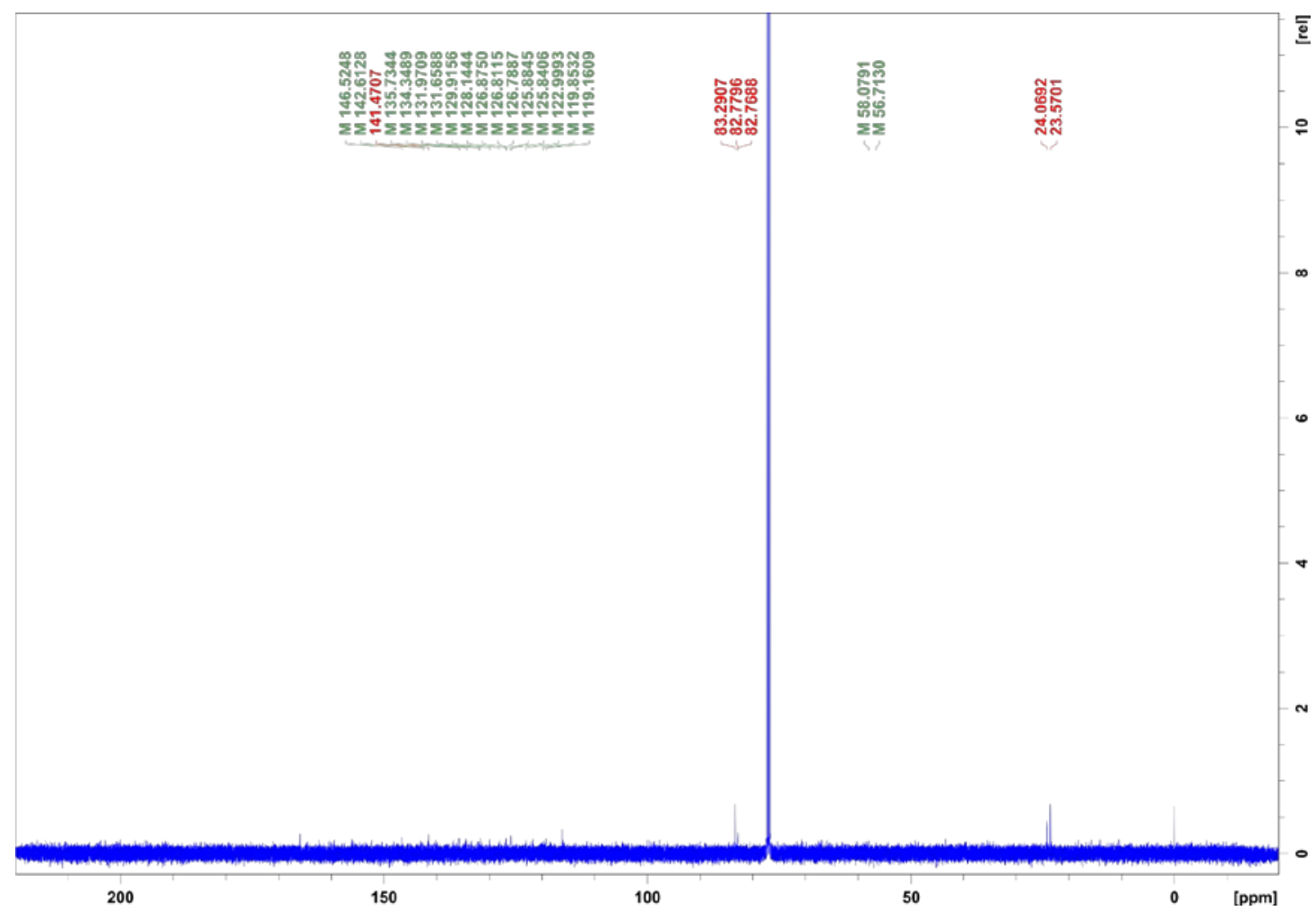

Fig. S79d ${ }^{13} \mathrm{C}$ NMR of 5-(Phenyl-2'-(boronic acid pinacol ester))-10,15,20-tris(pentafluorophenyl)chlorin $\mathbf{6 a}-\mathrm{H}_{2}$ in $\mathrm{CDCl}_{3}$. 


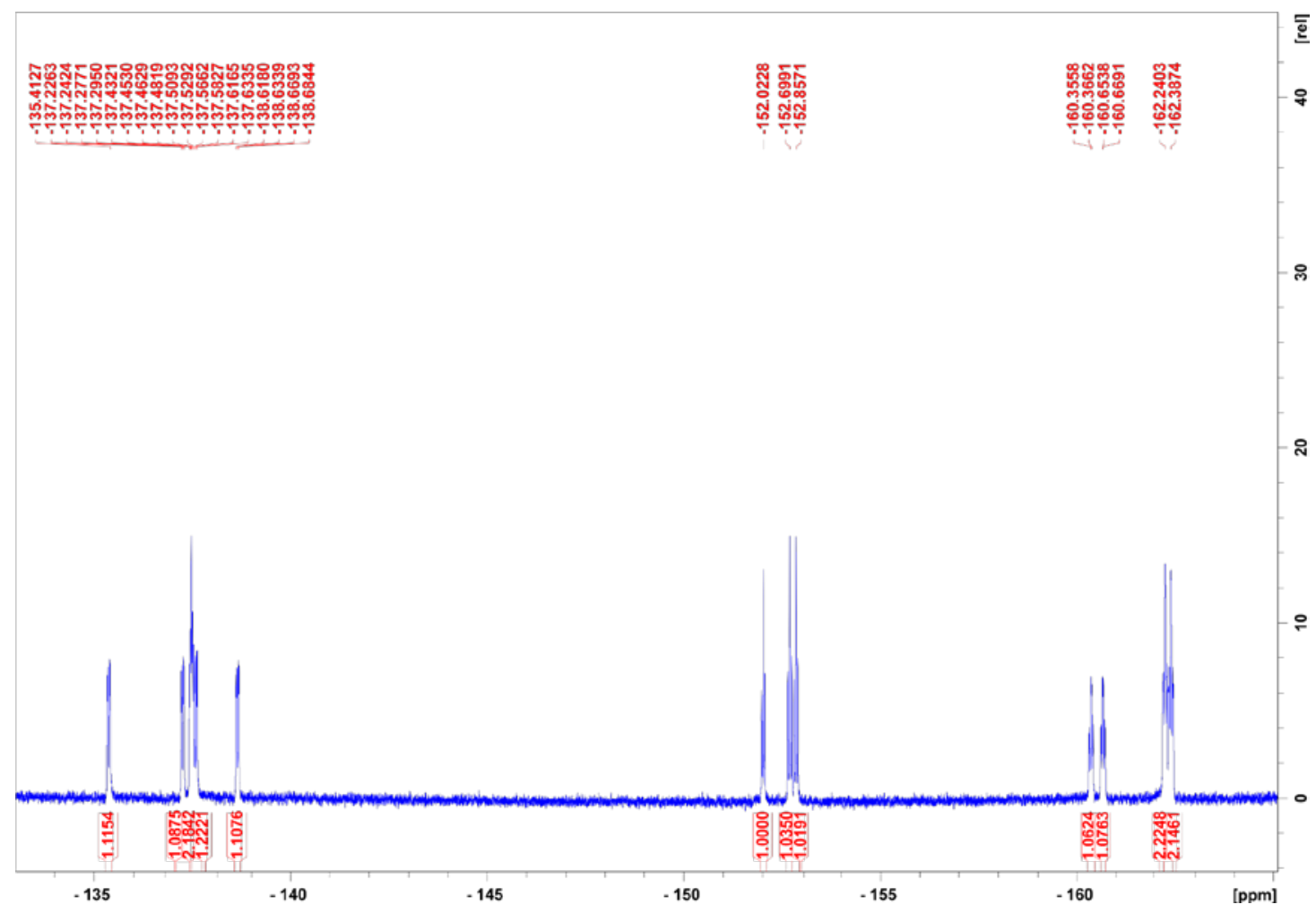

Fig. S79e ${ }^{19} \mathrm{~F}$ NMR of 5-(Phenyl-2'-(boronic acid pinacol ester))-10,15,20-tris(pentafluorophenyl)chlorin $\mathbf{6 a}-\mathbf{H}_{2}$ in $\mathrm{CDCl}_{3}$.

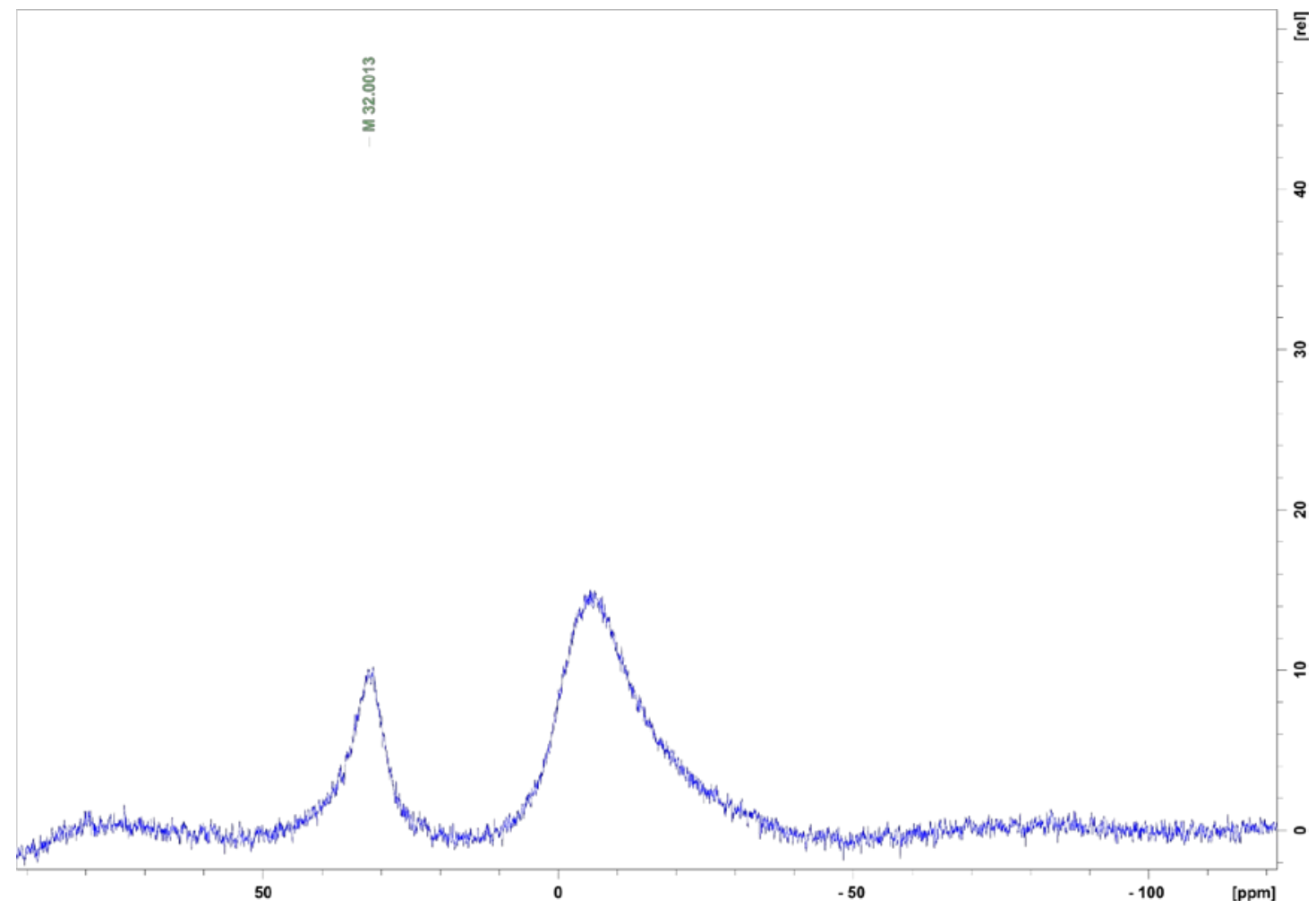

Fig. S79f ${ }^{11} \mathrm{~B}$ NMR of 5-(Phenyl-2'-(boronic acid pinacol ester))-10,15,20-tris(pentafluorophenyl)chlorin $\mathbf{6 a}-\mathbf{H}_{2}$ in $\mathrm{CDCl}_{3}$. 


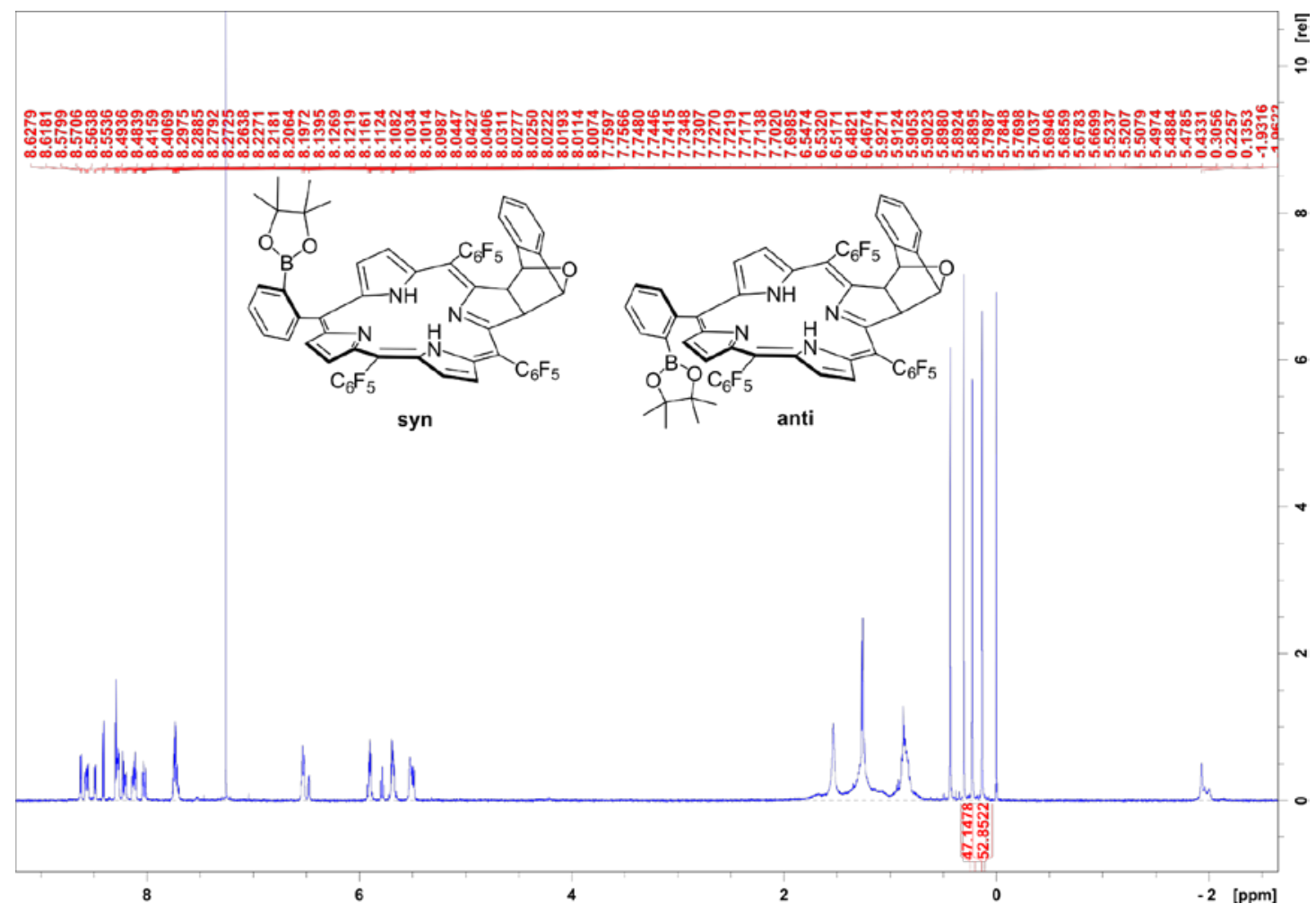

Fig. S80a ${ }^{1} \mathrm{H}$ NMR of 5-(Phenyl-2'-(boronic acid pinacol ester))-10,15,20-tris(pentafluorophenyl)chlorin $\mathbf{6 b}-\mathbf{H}_{2}$ in $\mathrm{CDCl}_{3}$ (mixture of syn and anti isomer (47:53)).

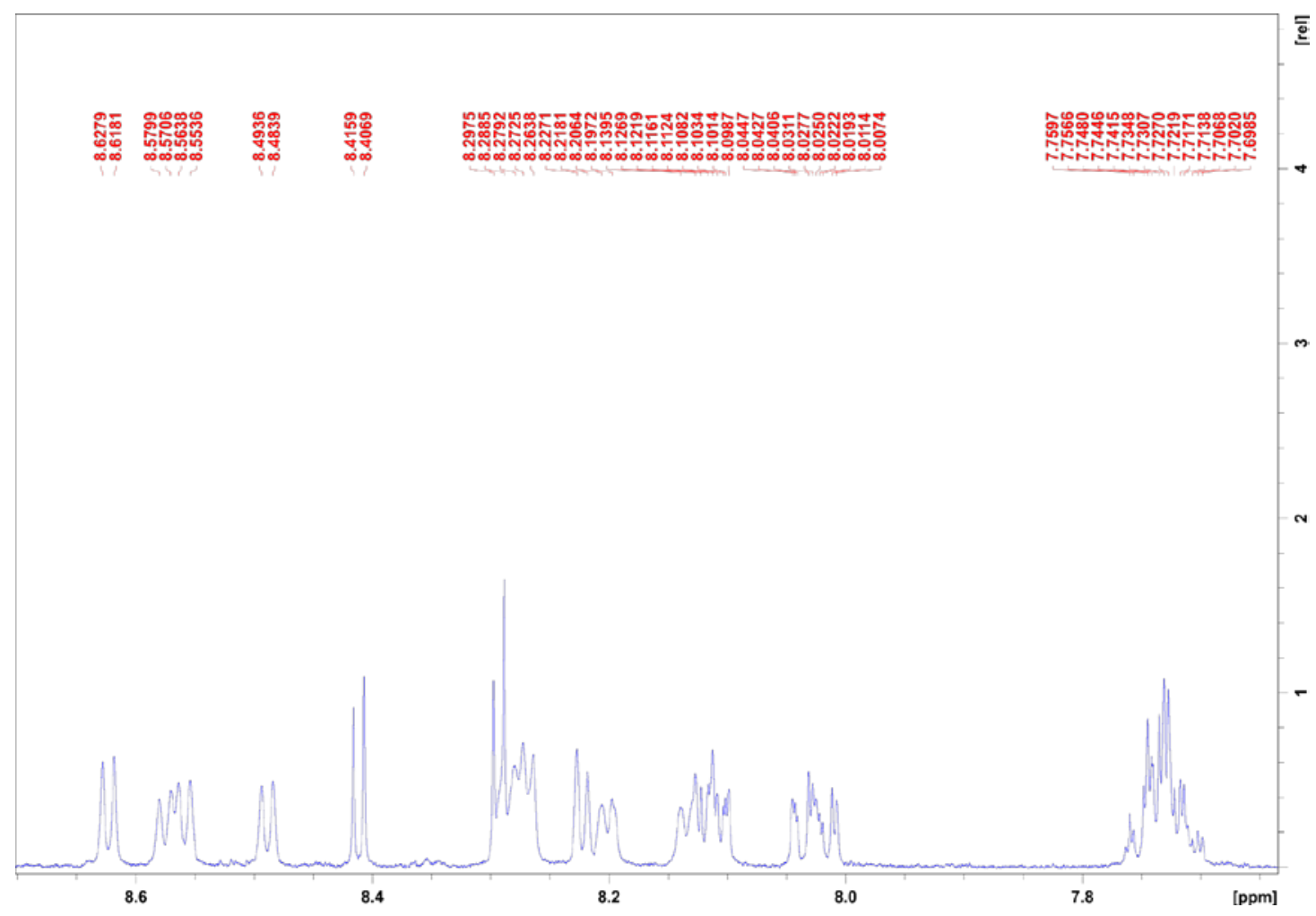

Fig. S80b Zoom of ${ }^{1} \mathrm{H}$ NMR of 5-(Phenyl-2'-(boronic acid pinacol ester))-10,15,20tris(pentafluorophenyl)- chlorin $\mathbf{6 b}-\mathbf{H}_{2}$ in $\mathrm{CDCl}_{3}$ (mixture of syn and anti isomer (47:53)). 


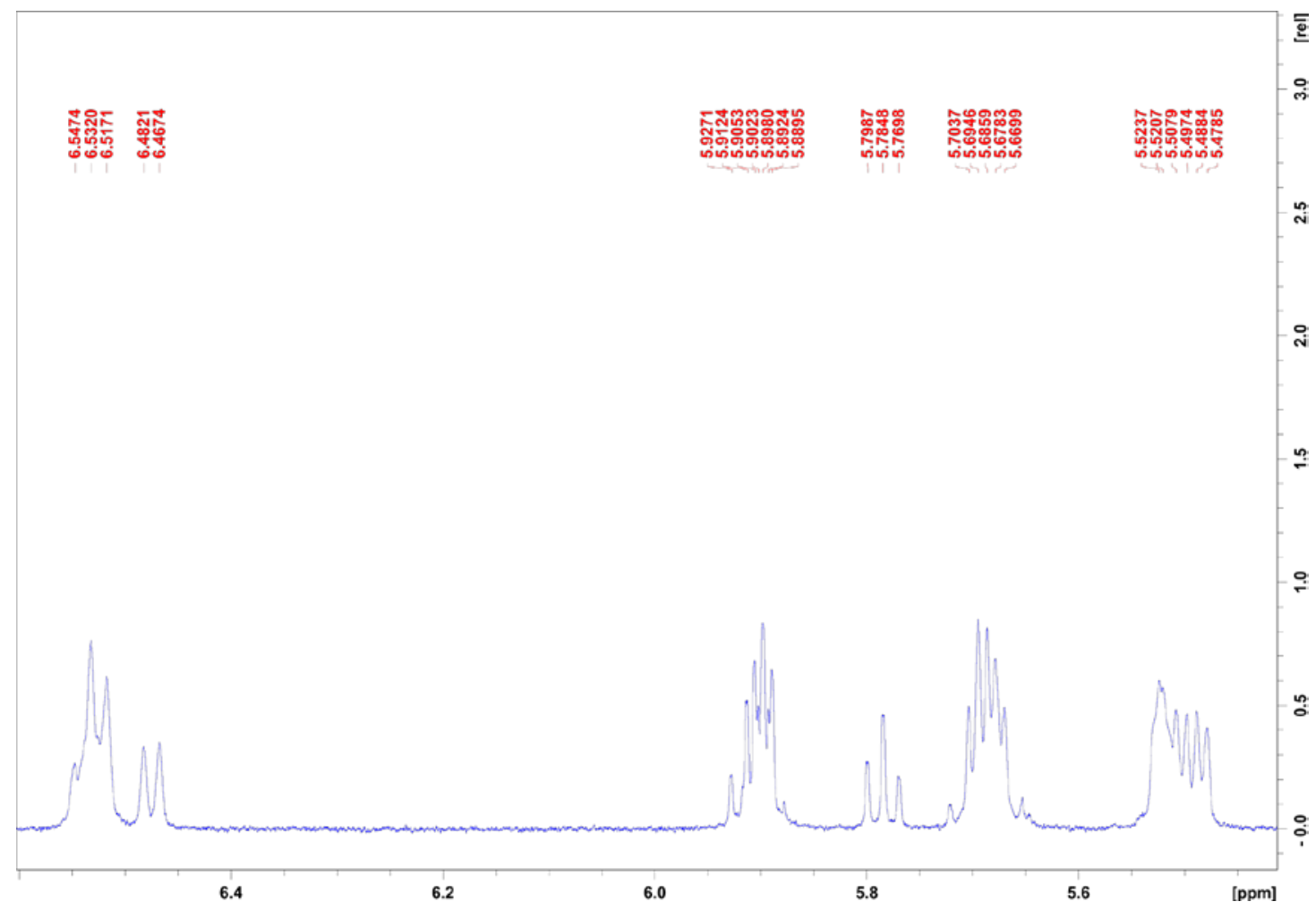

Fig. S80c Zoom of ${ }^{1} \mathrm{H}$ NMR of 5-(Phenyl-2'-(boronic acid pinacol ester))-10,15,20tris(pentafluorophenyl)- chlorin $\mathbf{6} \mathbf{b}-\mathbf{H}_{2}$ in $\mathrm{CDCl}_{3}$ (mixture of syn and anti isomer (47:53)).

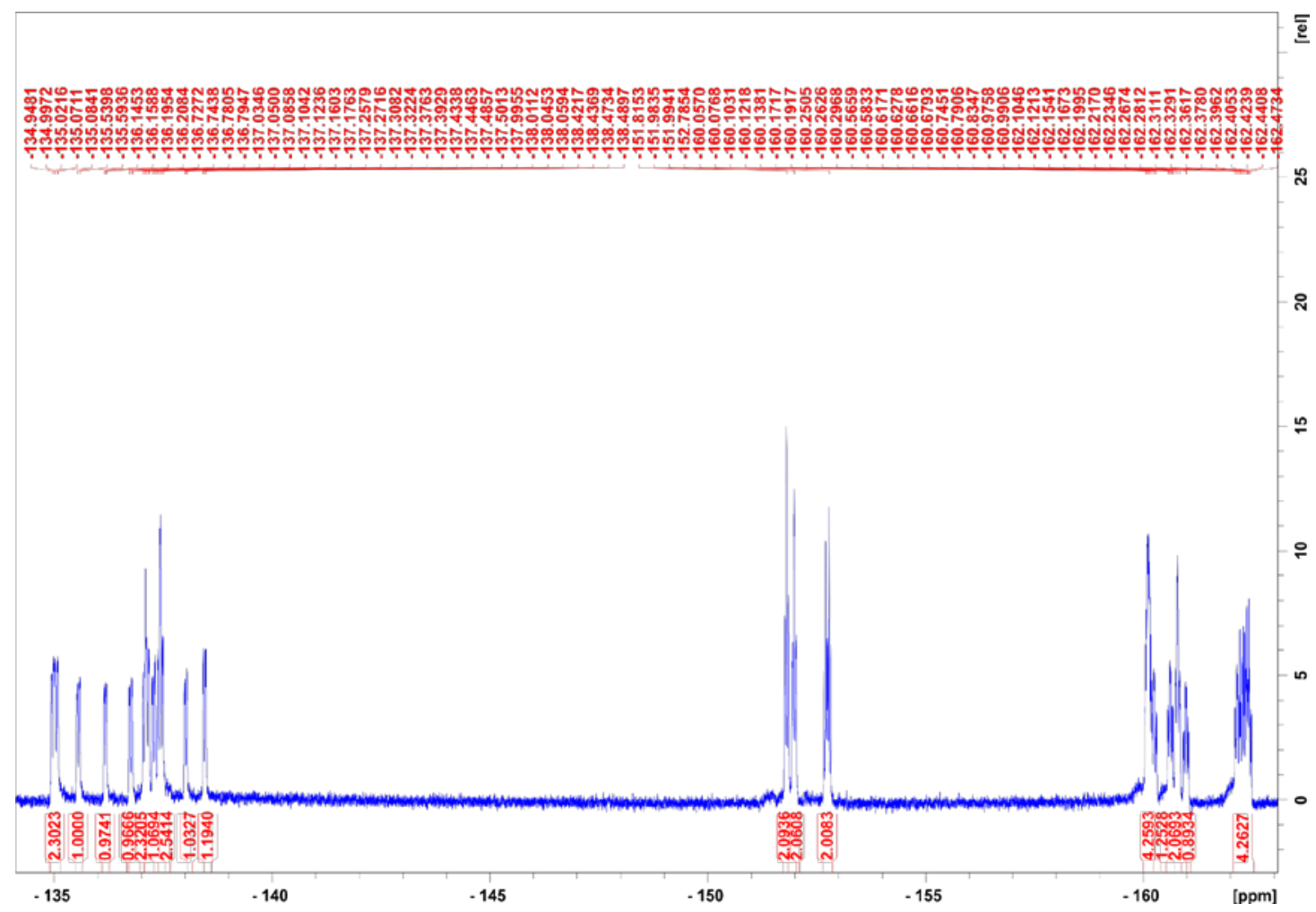

Fig. S80d ${ }^{19}$ F NMR of 5-(Phenyl-2'-(boronic acid pinacol ester))-10,15,20-tris(pentafluorophenyl)chlorin $\mathbf{6 b}-\mathbf{H}_{2}$ in $\mathrm{CDCl}_{3}$ (mixture of syn and anti isomer (47:53)). 


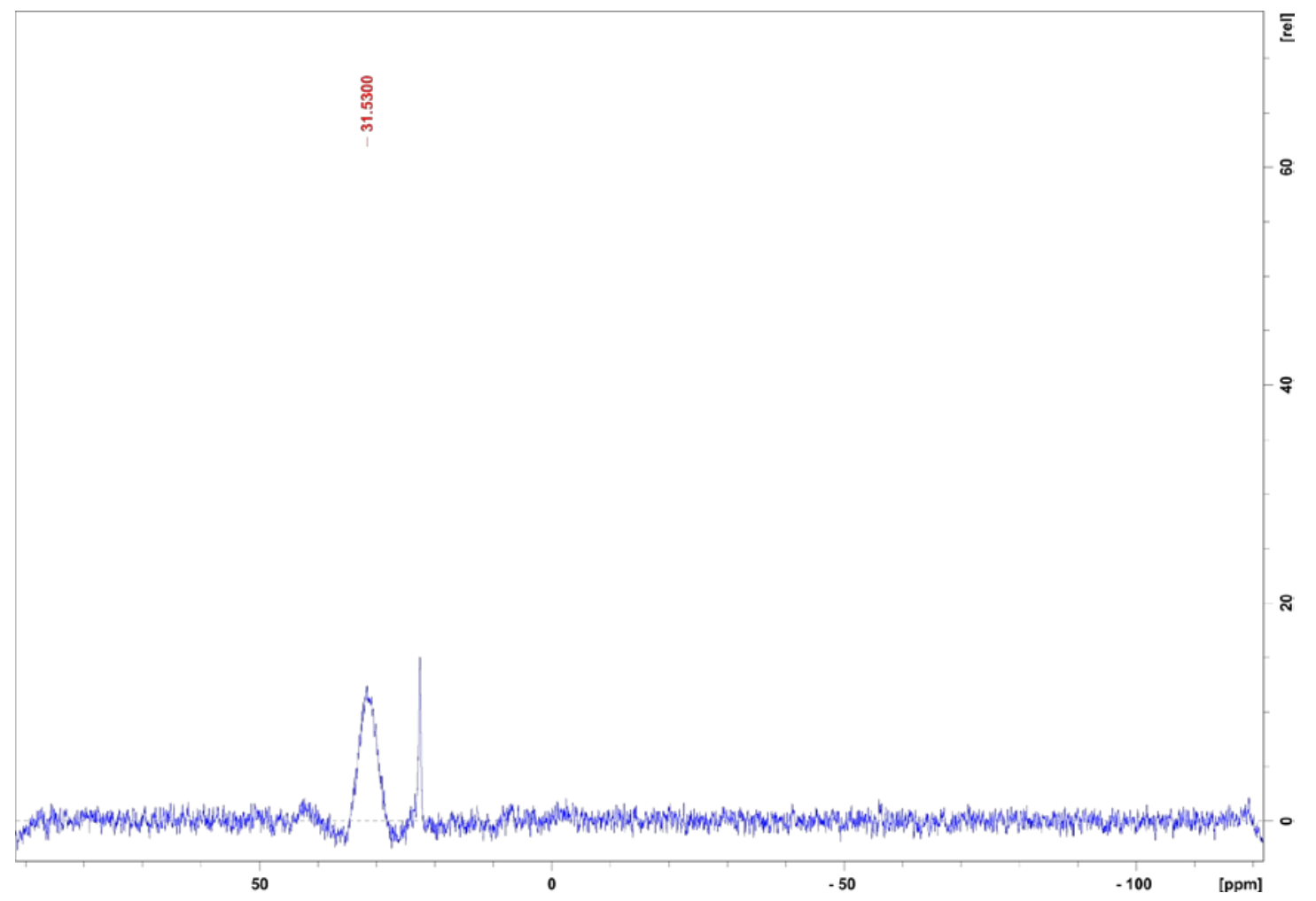

Fig. S80e ${ }^{11}$ B NMR of 5-(Phenyl-2'-(boronic acid pinacol ester))-10,15,20-tris(pentafluorophenyl)chlorin $\mathbf{6 b}-\mathbf{H}_{2}$ in $\mathrm{CDCl}_{3}$ (mixture of syn and anti isomer (47:53)).

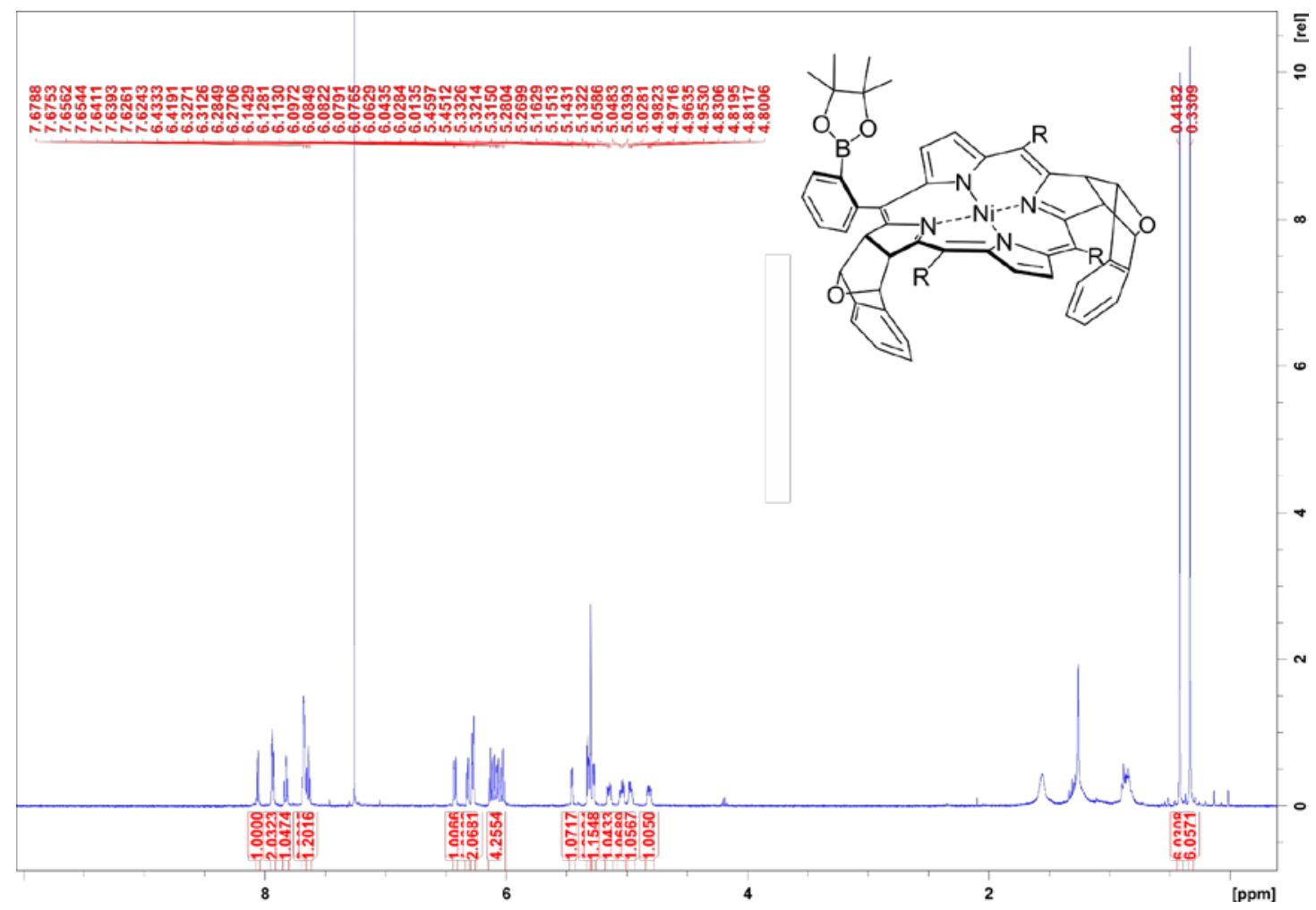

Fig. S81a ${ }^{1} \mathrm{H}-\mathrm{NMR}$ of 5-(Phenyl-2'-(boronic acid pinacol ester))-10,15,20-tris(pentafluorophenyl)$\mathrm{Ni}(\mathrm{II})$ bacteriochlorin 7-Ni in $\mathrm{CDCl}_{3}\left(\mathrm{R}=\mathrm{C}_{6} \mathrm{~F}_{5}\right)$. 


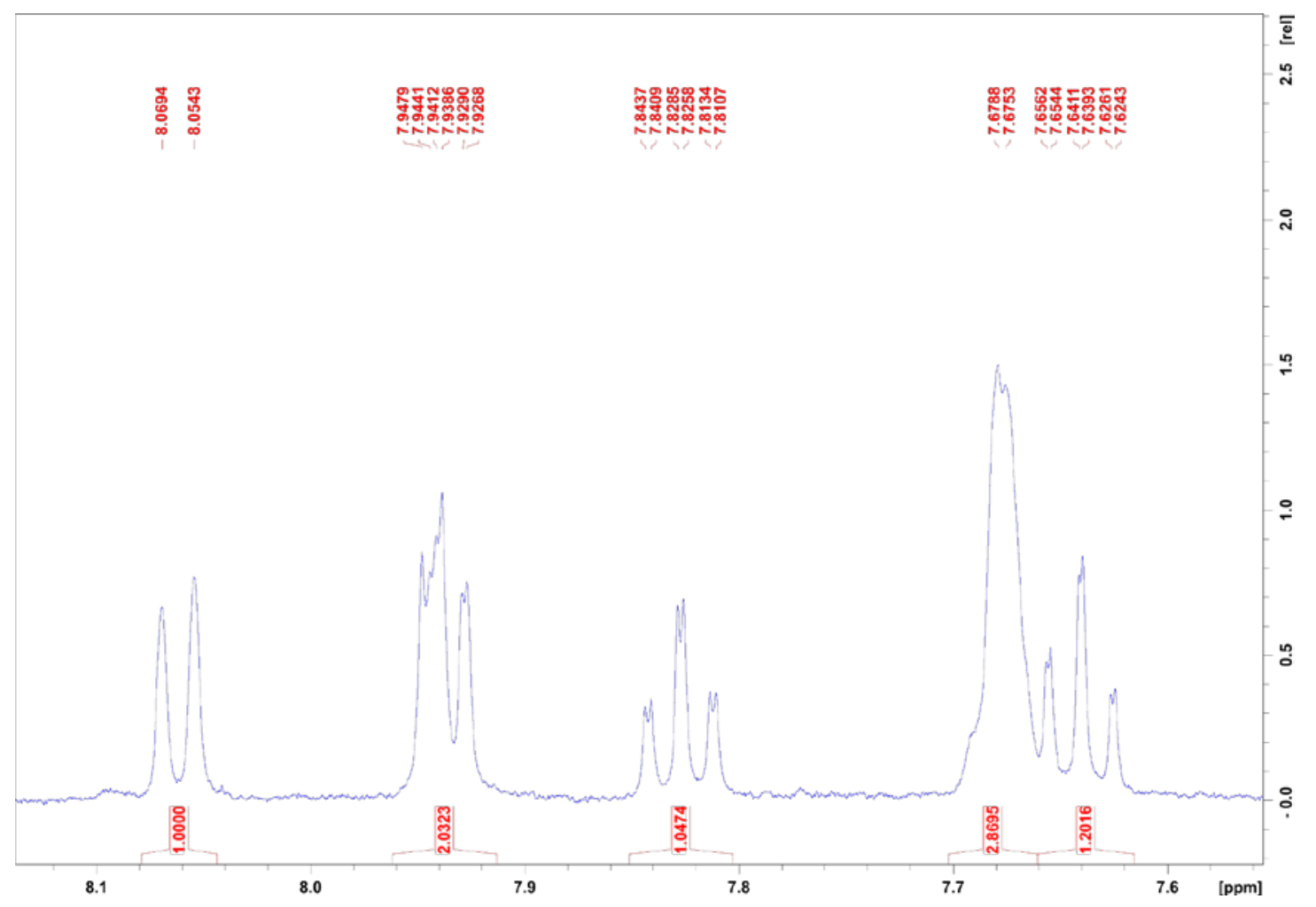

Fig. S81b Zoom of ${ }^{1}$ H-NMR of 5-(Phenyl-2'-(boronic acid pinacol ester))-10,15,20tris(pentafluorophenyl)- Ni(II)bacteriochlorin 7-Ni in $\mathrm{CDCl}_{3}\left(\mathrm{R}=\mathrm{C}_{6} \mathrm{~F}_{5}\right)$.

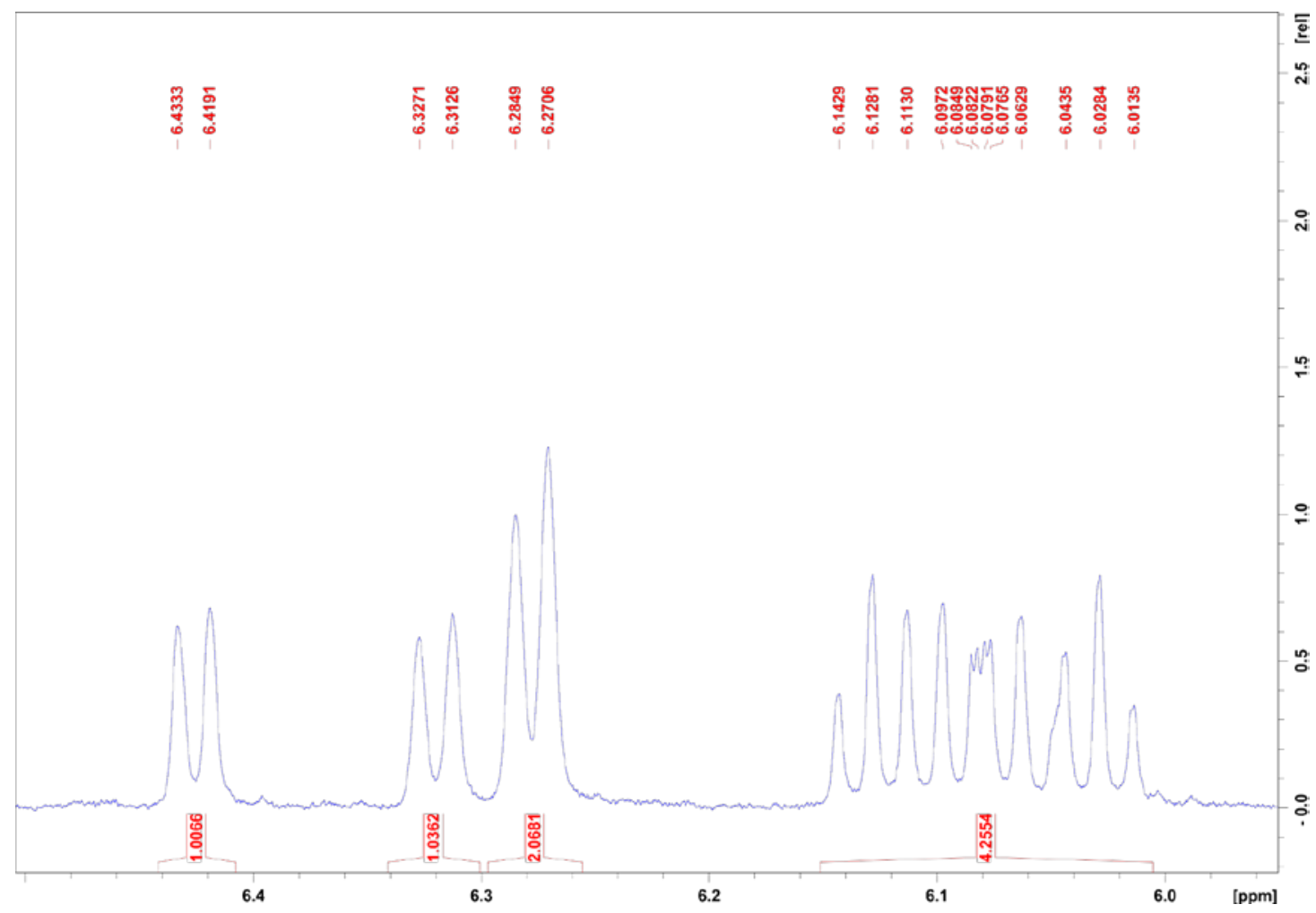

Fig. S81c Zoom of $\quad{ }^{1} \mathrm{H}-\mathrm{NMR}$ of 5-(Phenyl-2'-(boronic acid pinacol ester))-10,15,20tris(pentafluorophenyl)- Ni(II)bacteriochlorin 7-Ni in $\mathrm{CDCl}_{3}\left(\mathrm{R}=\mathrm{C}_{6} \mathrm{~F}_{5}\right)$. 


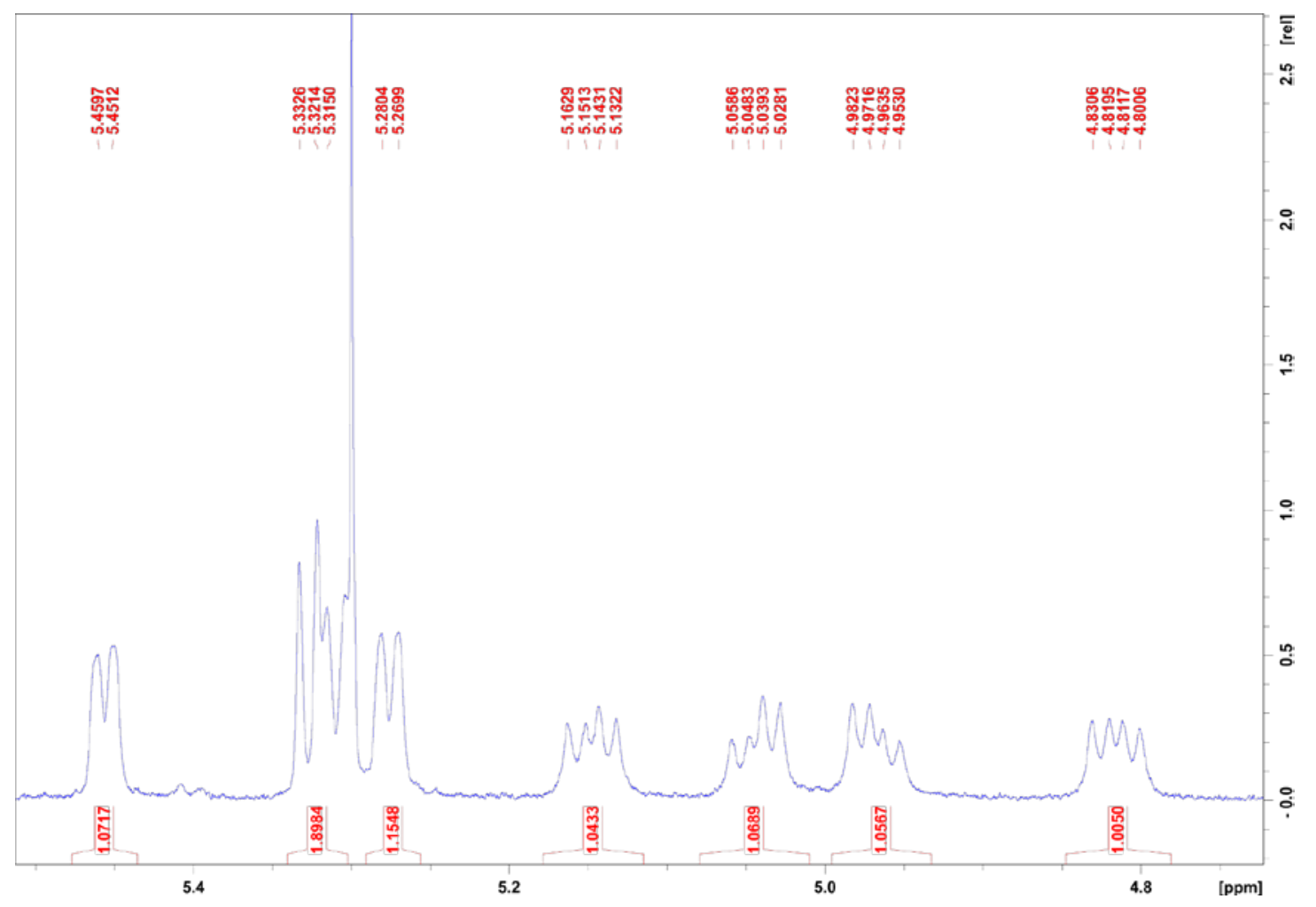

Fig. S81d Zoom of ${ }^{1}$ H-NMR of 5-(Phenyl-2'-(boronic acid pinacol ester))-10,15,20tris(pentafluorophenyl)- Ni(II)bacteriochlorin 7-Ni in $\mathrm{CDCl}_{3}\left(\mathrm{R}=\mathrm{C}_{6} \mathrm{~F}_{5}\right)$.

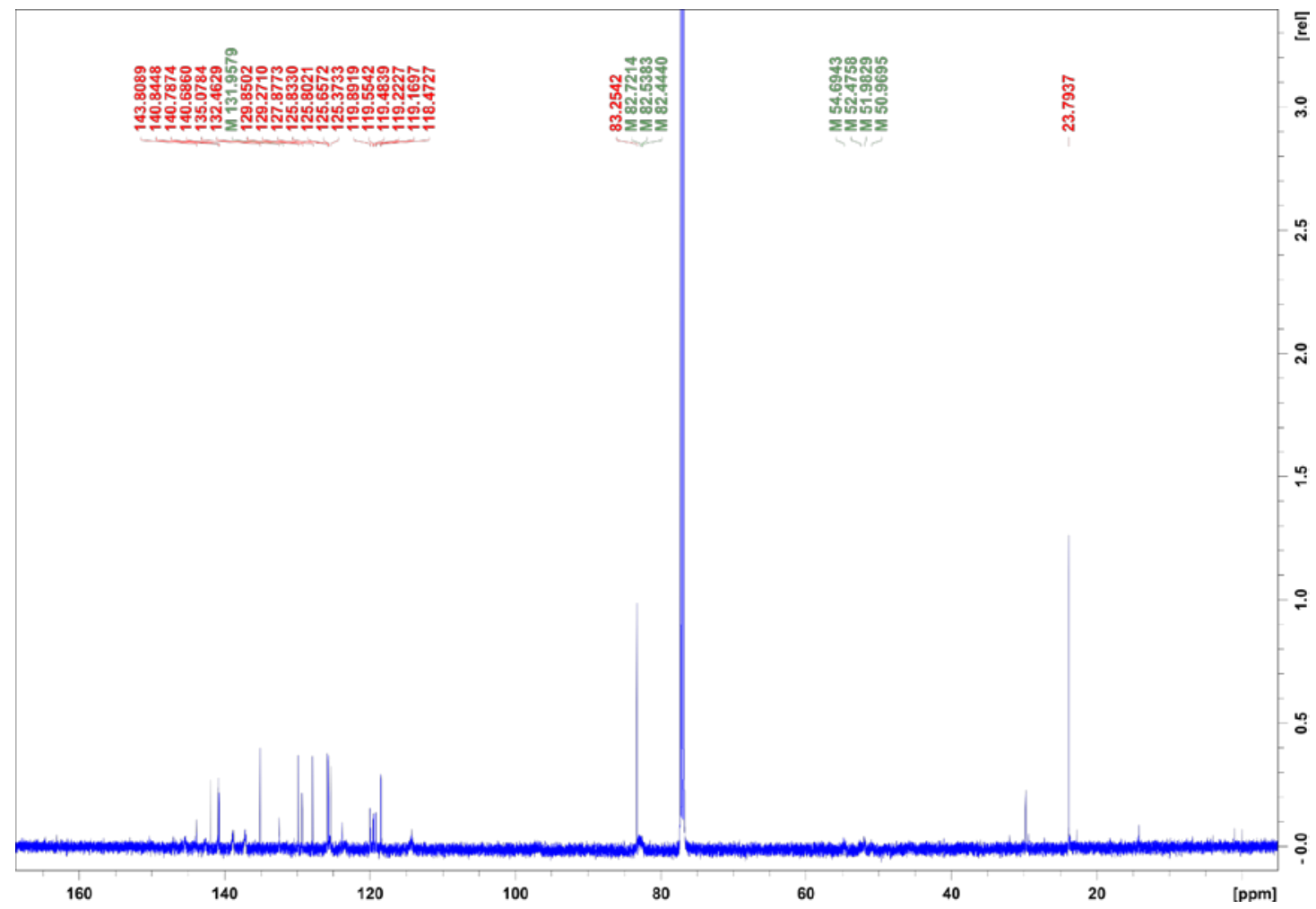

Fig. S81e ${ }^{13} \mathrm{C}$ NMR of 5-(Phenyl-2'-(boronic acid pinacol ester))-10,15,20-tris(pentafluorophenyl)$\mathrm{Ni}(\mathrm{II})$ bacteriochlorin 7-Ni in $\mathrm{CDCl}_{3}$. 


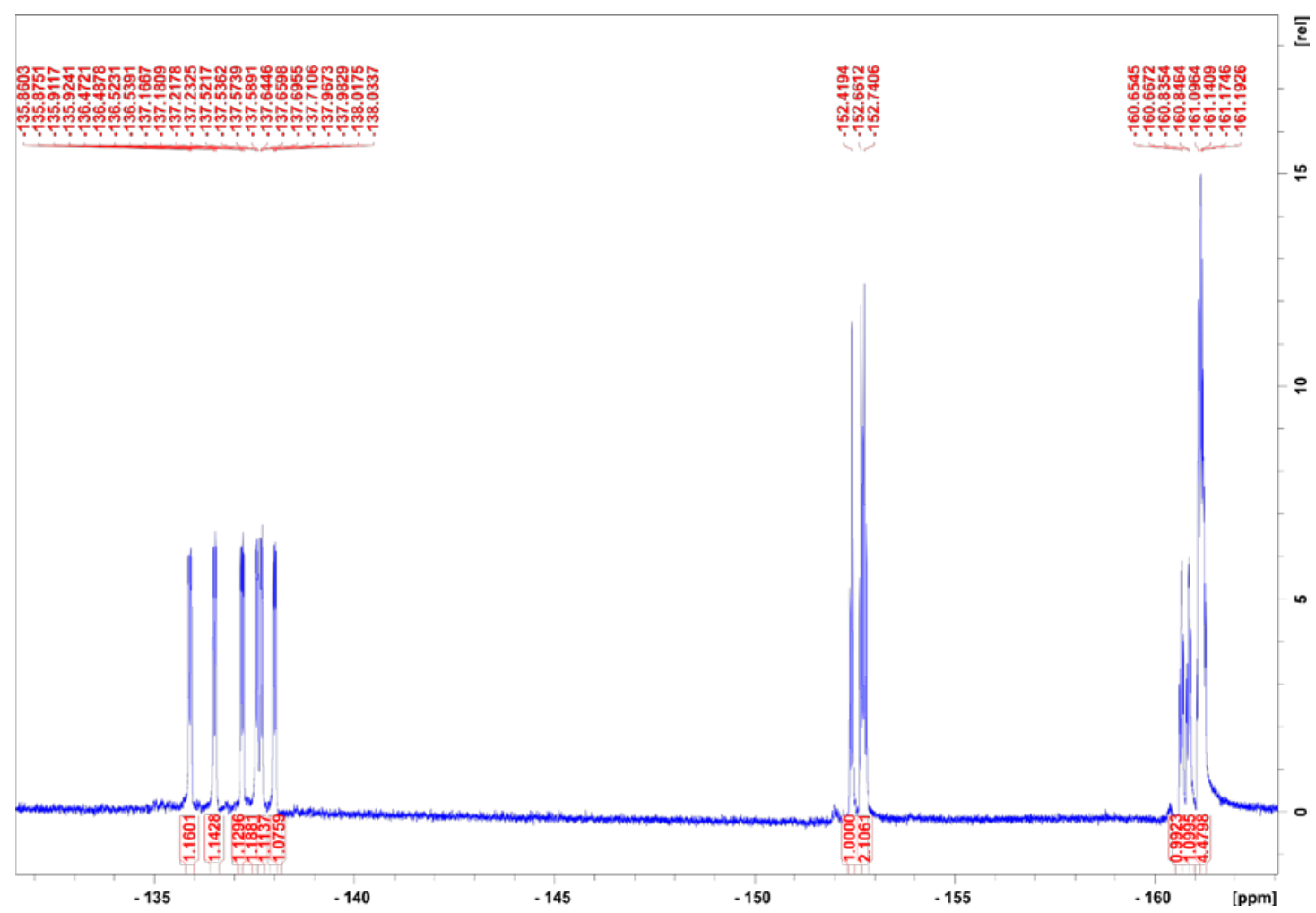

Fig. S81f ${ }^{19} \mathrm{~F}$ NMR of 5-(Phenyl-2'-(boronic acid pinacol ester))-10,15,20-tris(pentafluorophenyl)$\mathrm{Ni}(\mathrm{II})$ bacteriochlorin 7-Ni in $\mathrm{CDCl}_{3}$.

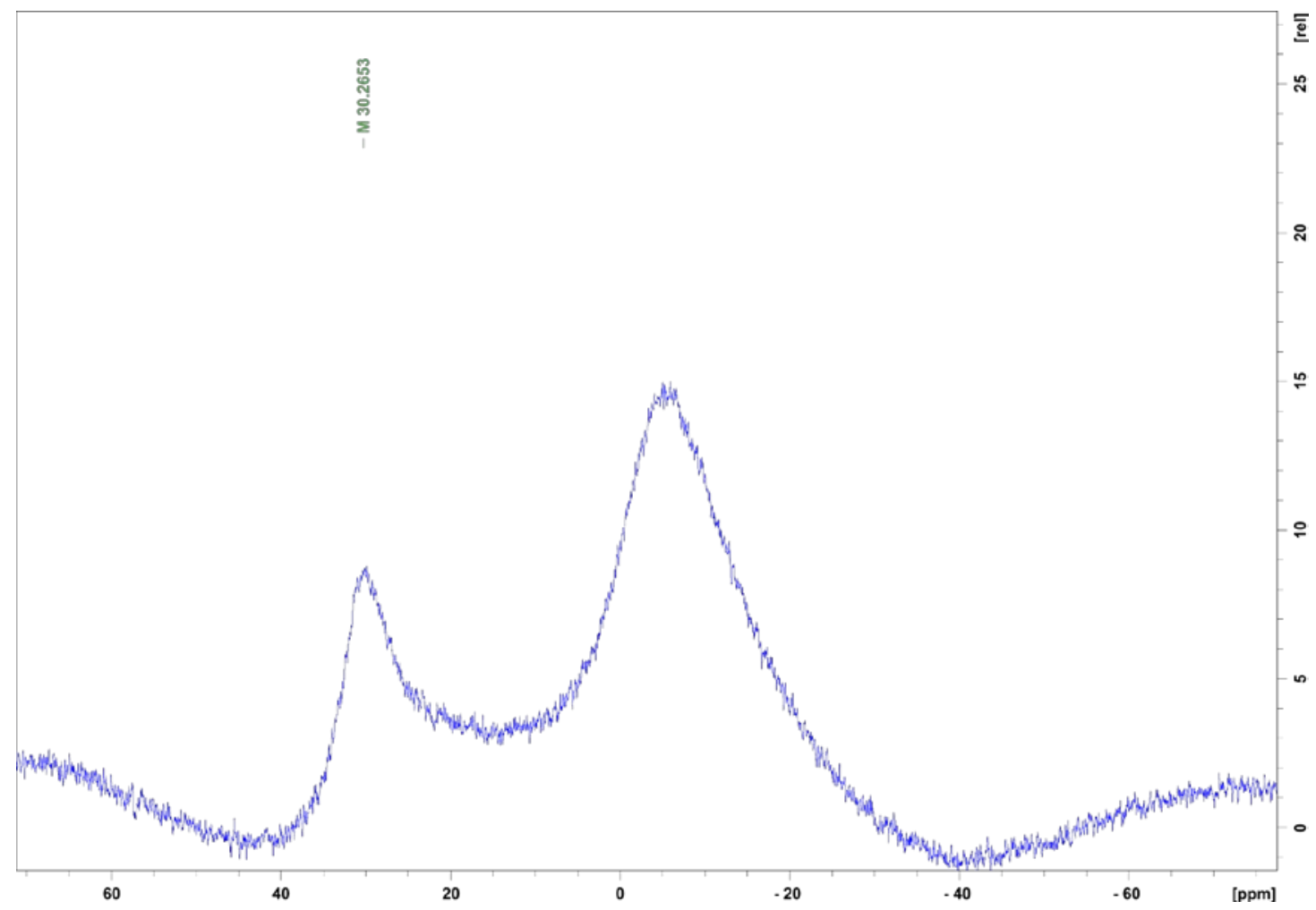

Fig. S81g ${ }^{11} \mathrm{~B}$ NMR of 5-(Phenyl-2'-(boronic acid pinacol ester))-10,15,20-tris(pentafluorophenyl)$\mathrm{Ni}(\mathrm{II})$ bacteriochlorin 7-Ni in $\mathrm{CDCl}_{3}$. 


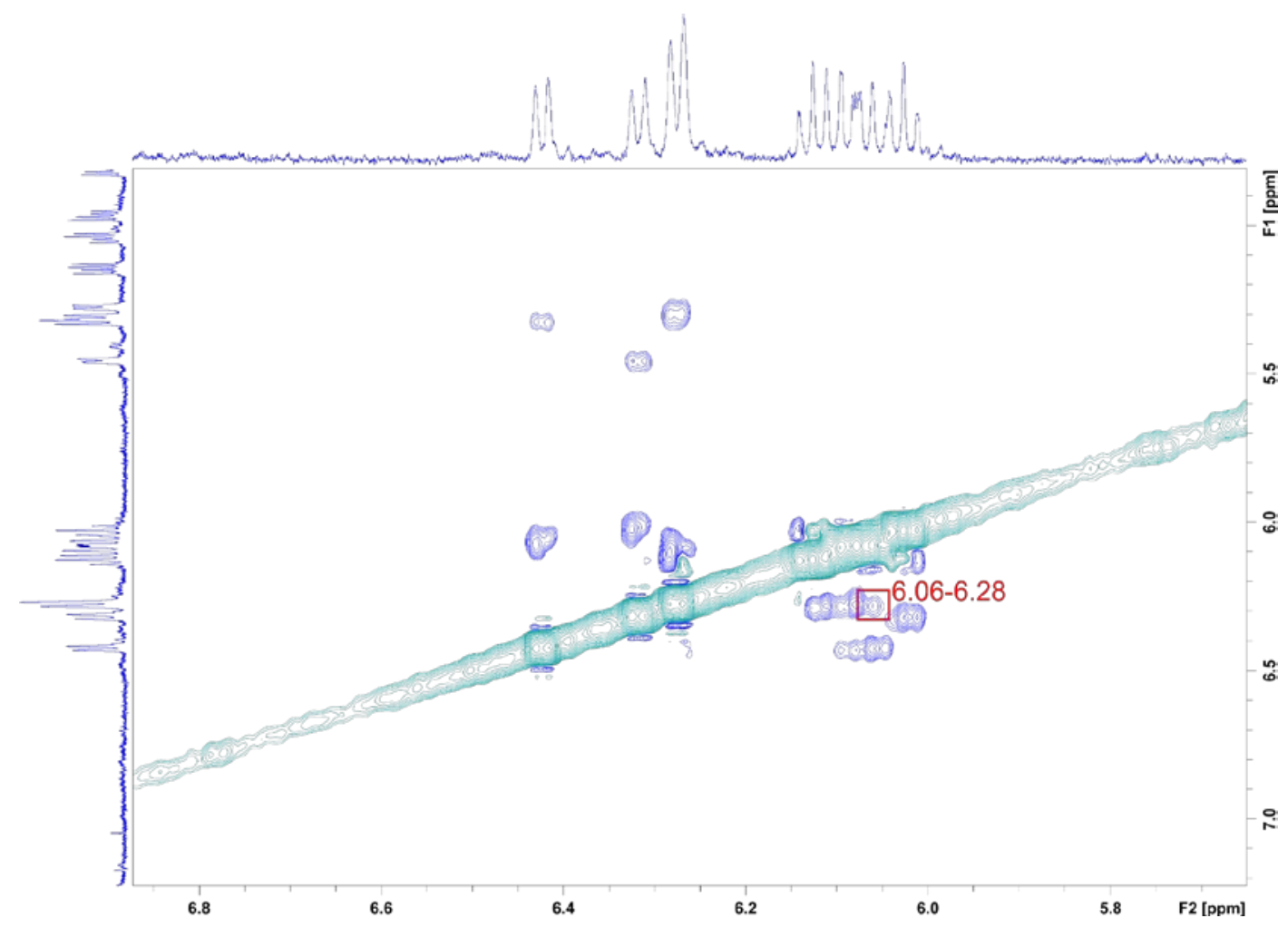

Fig. S81h $\quad{ }^{1}$ H-NOESY-NMR of 5-(Phenyl-2'-(boronic acid pinacol ester))-10,15,20tris(pentafluorophenyl)Ni(II)bacteriochlorin 7-Ni in $\mathrm{CDCl}_{3}$. The signal in the red square proves the syn orientation of the isobenzofuran rings.

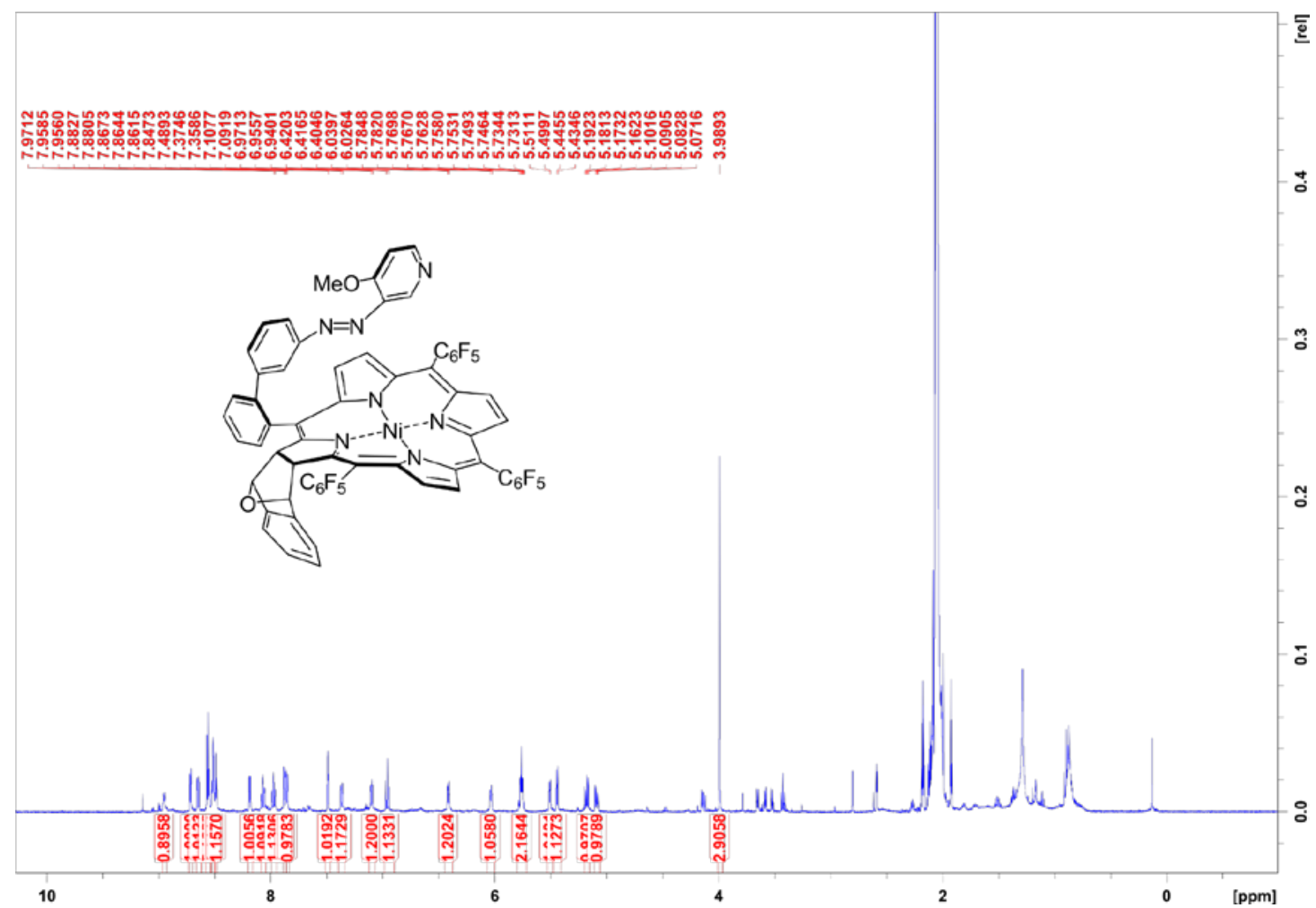

Fig. S82a ${ }^{1} \mathrm{H}$ NMR of 5-(Biphenylazo-4-methoxypyridine)-10,15,20-tris(pentafluorophenyl)nickel(II)chlorin 10a in Aceton- $\mathrm{d}_{6}+10 \mu \mathrm{L}$ TFA. 


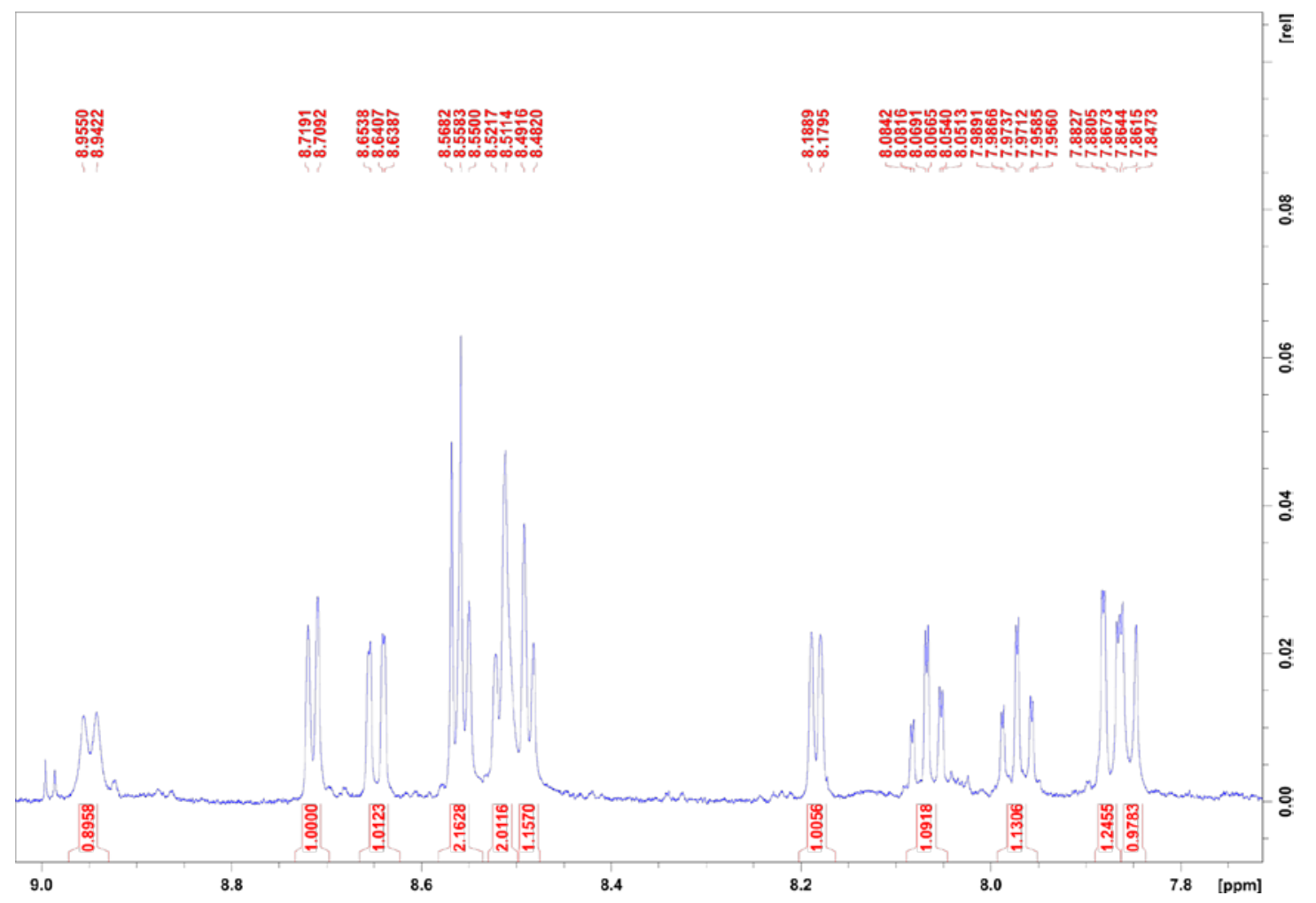

Fig. S82b Zoom of $\quad{ }^{1} \mathrm{H} \quad$ NMR of $\quad$ 5-(Biphenylazo-4-methoxypyridine)-10,15,20tris(pentafluorophenyl)nickel(II)-chlorin 10a in Aceton- $\mathrm{d}_{6}+10 \mu \mathrm{L}$ TFA.

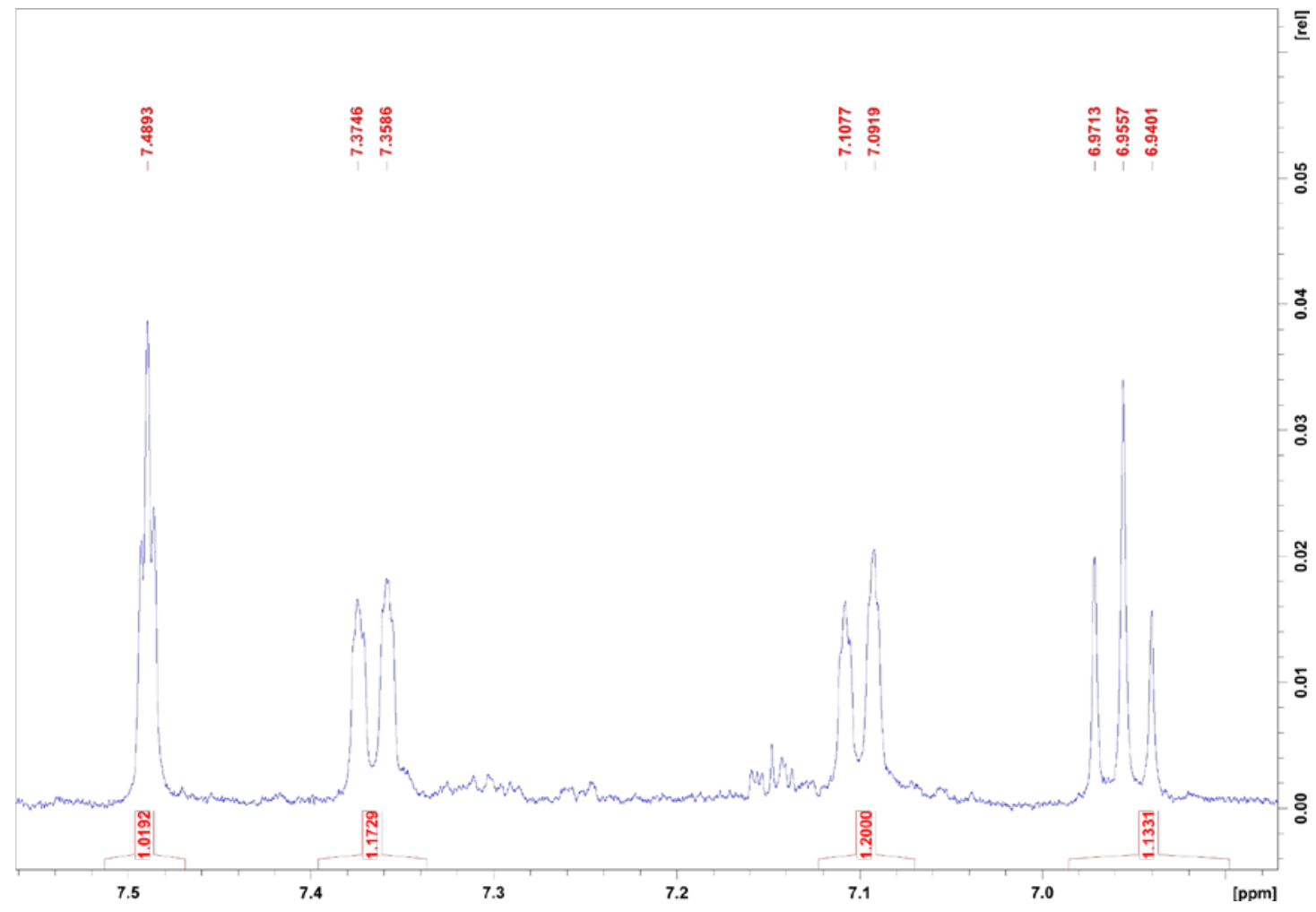

Fig. S82c Zoom of $\quad{ }^{1} \mathrm{H} \quad$ NMR of $\quad$ 5-(Biphenylazo-4-methoxypyridine)-10,15,20tris(pentafluorophenyl)nickel(II)-chlorin 10a in Aceton- $\mathrm{d}_{6}+10 \mu \mathrm{L}$ TFA. 


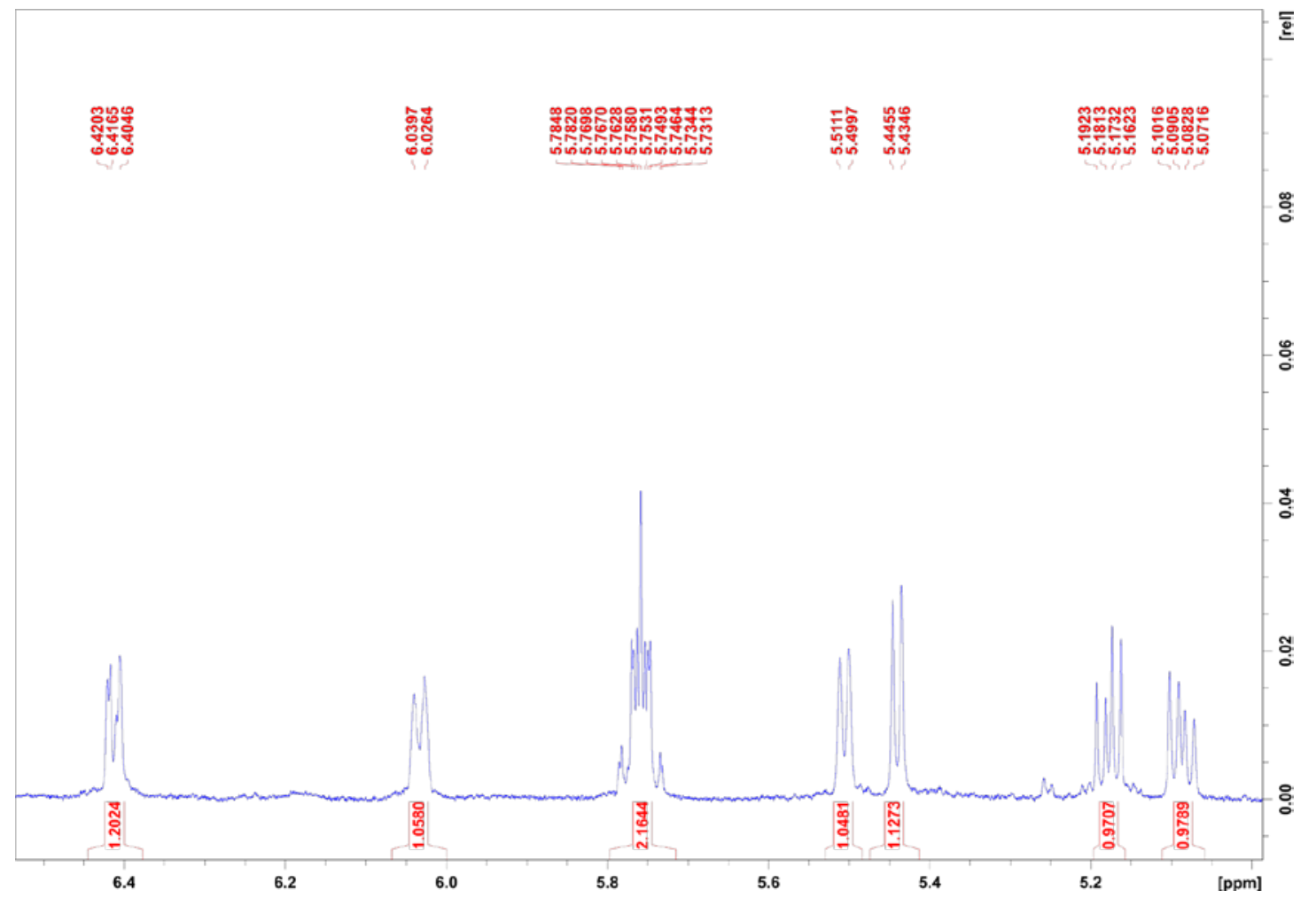

Fig. S82d Zoom of $\quad{ }^{1} \mathrm{H} \quad$ NMR of 5-(Biphenylazo-4-methoxypyridine)-10,15,20tris(pentafluorophenyl)nickel(II)-chlorin 10a in Aceton- $\mathrm{d}_{6}+10 \mu \mathrm{L}$ TFA.

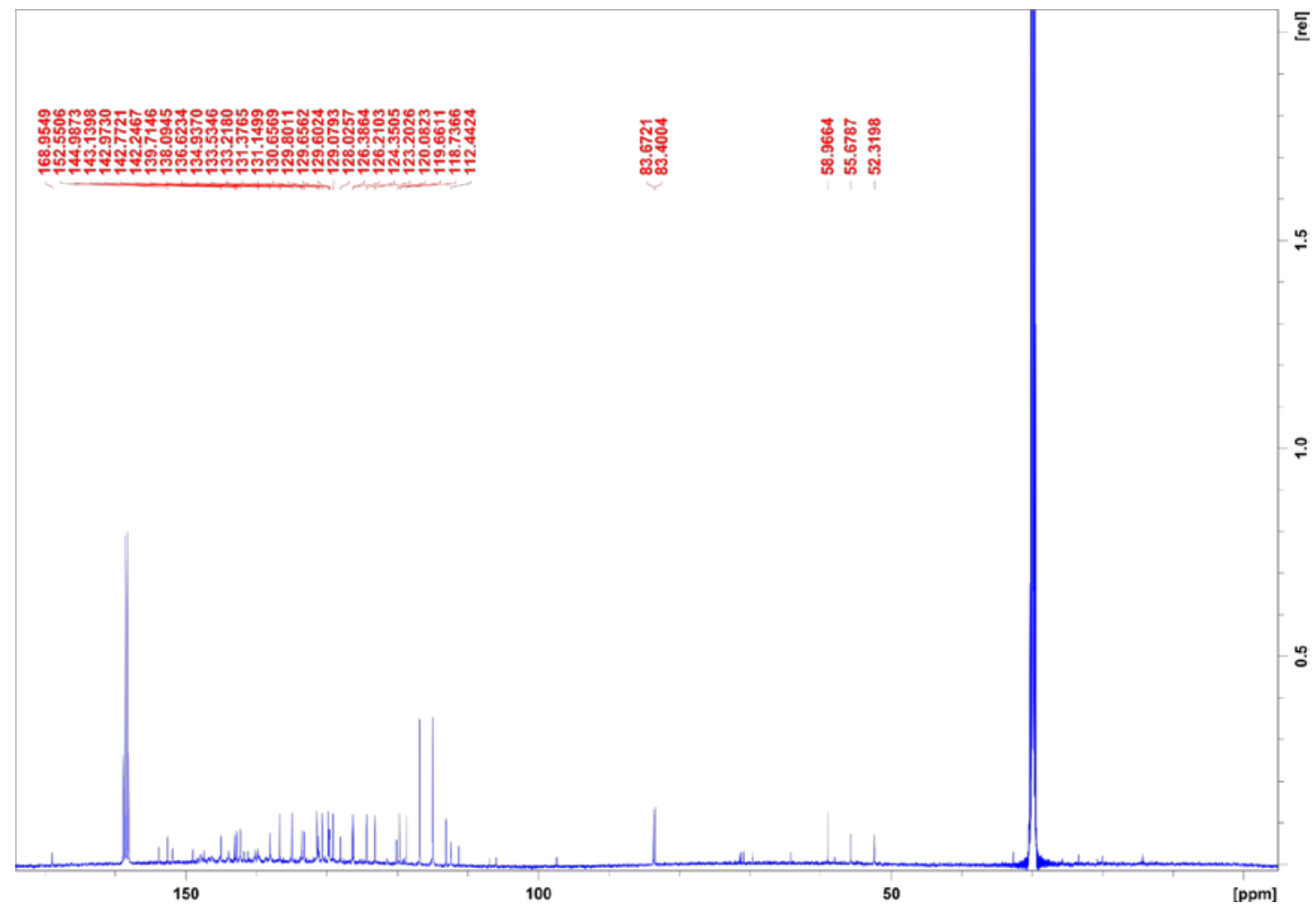

Fig. S82e ${ }^{13} \mathrm{C}$ NMR of 5-(Biphenylazo-4-methoxypyridine)-10,15,20-tris(pentafluorophenyl)-nickel(II) chlorin 10a in Aceton- $\mathrm{d}_{6}+10 \mu \mathrm{L}$ TFA. 


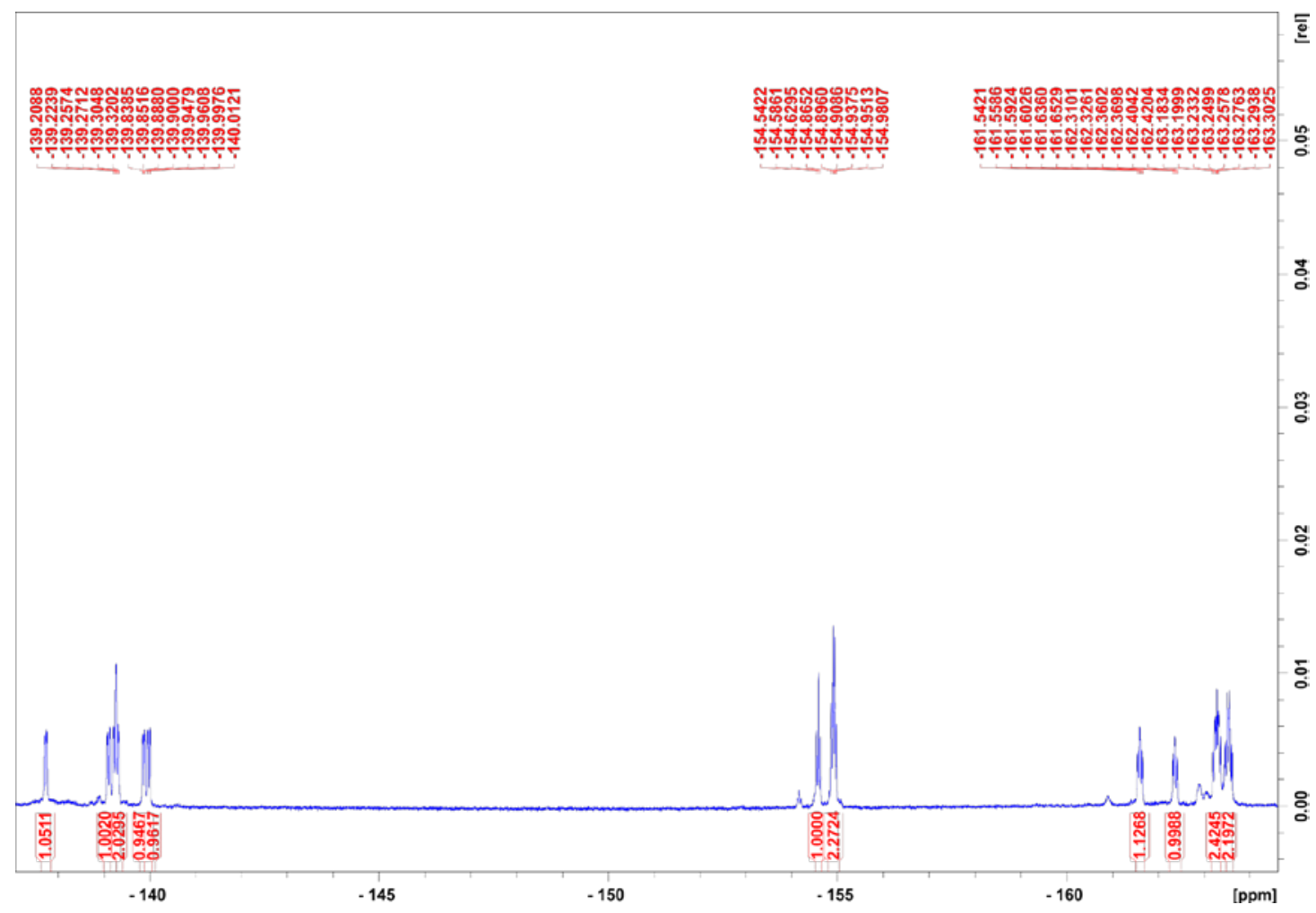

Fig. S82f ${ }^{19} \mathrm{~F} \quad$ NMR of 5-(Biphenylazo-4-methoxypyridine)-10,15,20-tris(pentafluorophenyl)nickel(II)chlorin 10a in Aceton-d $\mathrm{d}_{6}+10 \mu \mathrm{L}$ TFA.

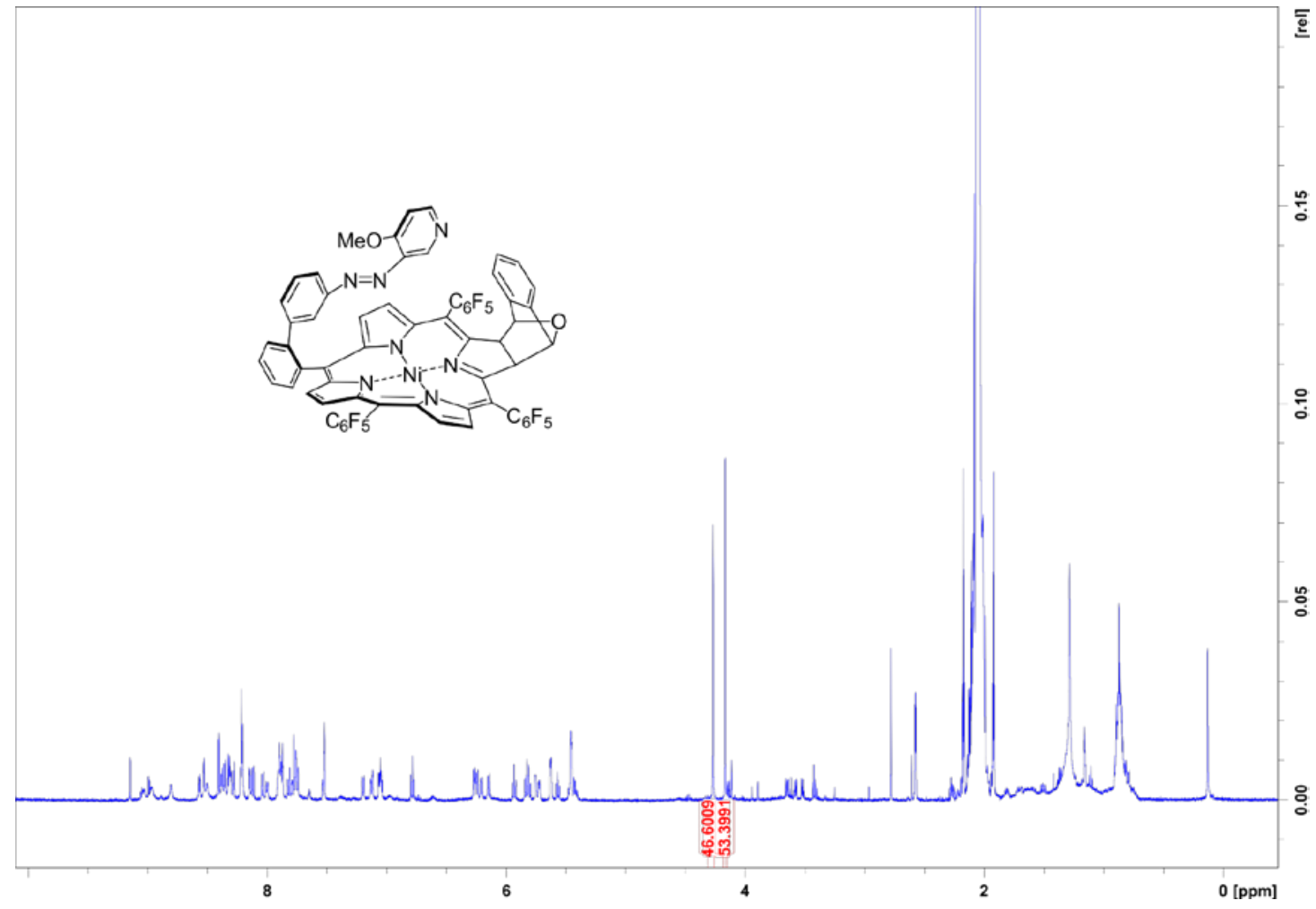

Fig. S83a $\quad{ }^{1} \mathrm{H} \quad \mathrm{NMR}$ of $\quad$ 5-(Biphenylazo-4-methoxypyridine)-10,15,20-tris(pentafluorophenyl)nickel(II)chlorin 10b in Aceton- $\mathrm{d}_{6}+10 \mu \mathrm{L}$ TFA (mixture of syn and anti isomer (47:53)). 


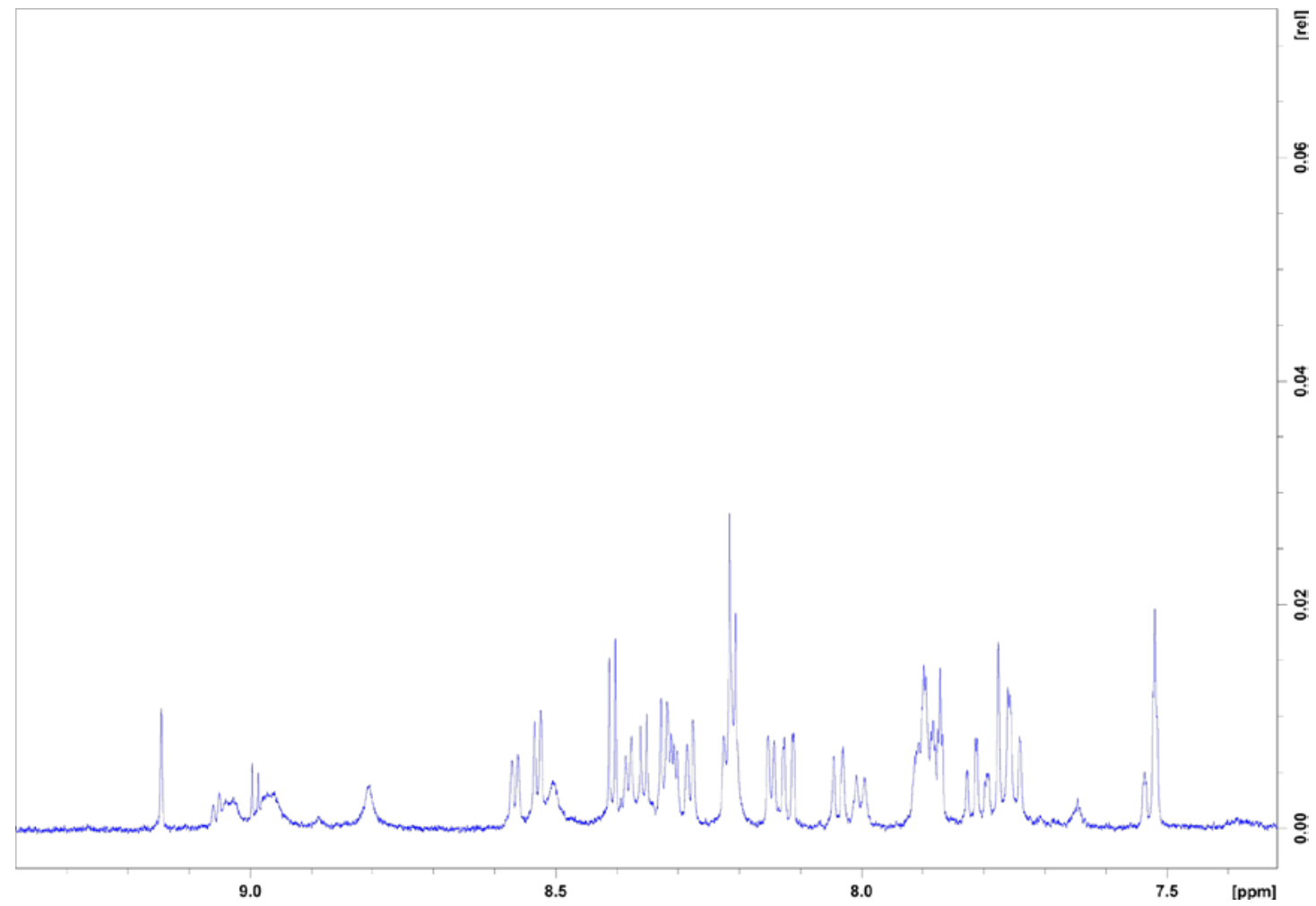

Fig. S83b $\quad{ }^{1} \mathrm{H} \quad$ NMR of $\quad$ 5-(Biphenylazo-4-methoxypyridine)-10,15,20-tris(pentafluorophenyl)nickel(II)chlorin 10b in Aceton- $\mathrm{d}_{6}+10 \mu \mathrm{L}$ TFA (mixture of syn and anti isomer (47:53)).

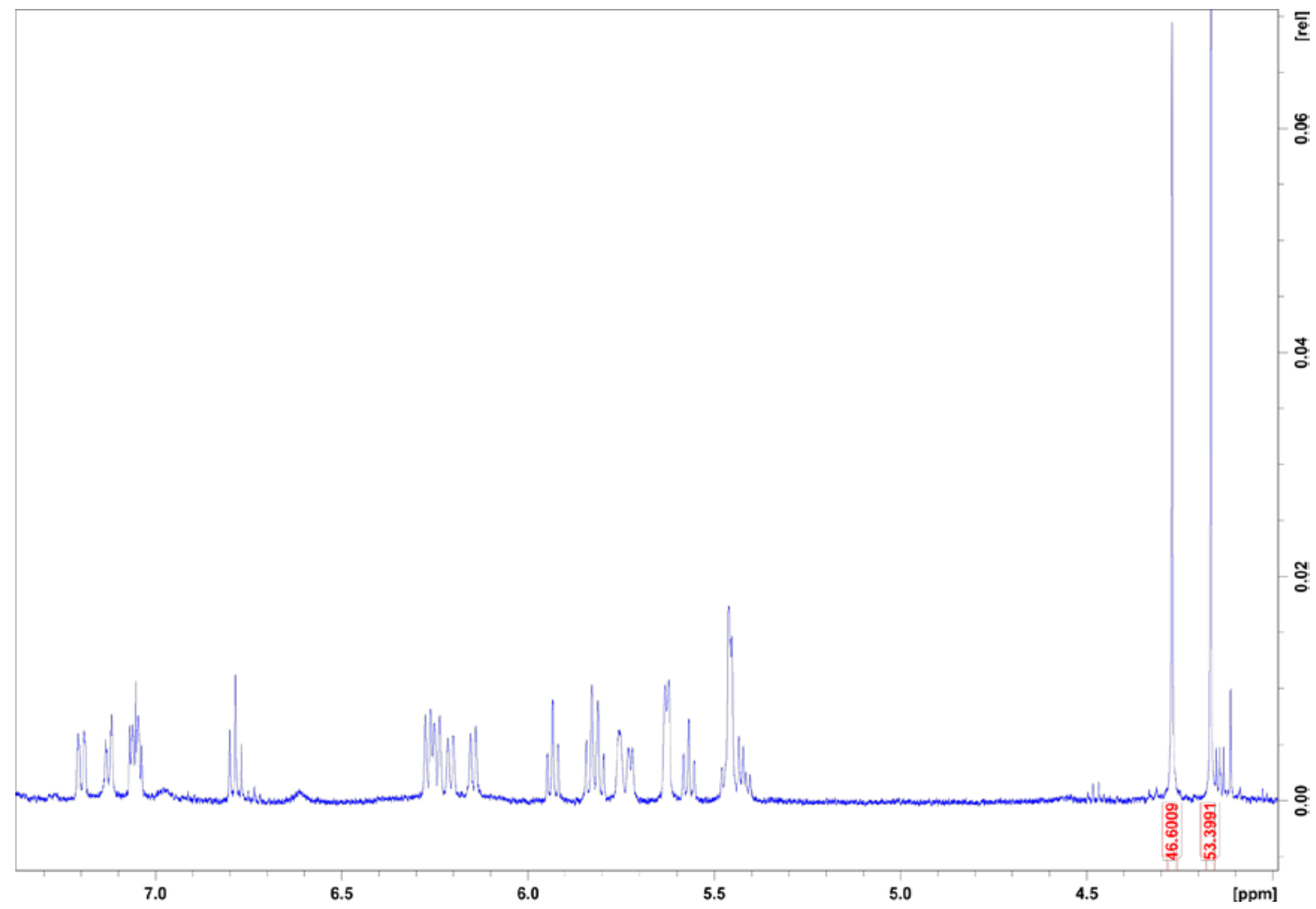

Fig. S83c $\quad{ }^{1} \mathrm{H} \quad \mathrm{NMR}$ of $\quad$ 5-(Biphenylazo-4-methoxypyridine)-10,15,20-tris(pentafluorophenyl)nickel(II)chlorin 10b in Aceton- $\mathrm{d}_{6}+10 \mu \mathrm{L}$ TFA (mixture of syn and anti isomer (47:53)). 


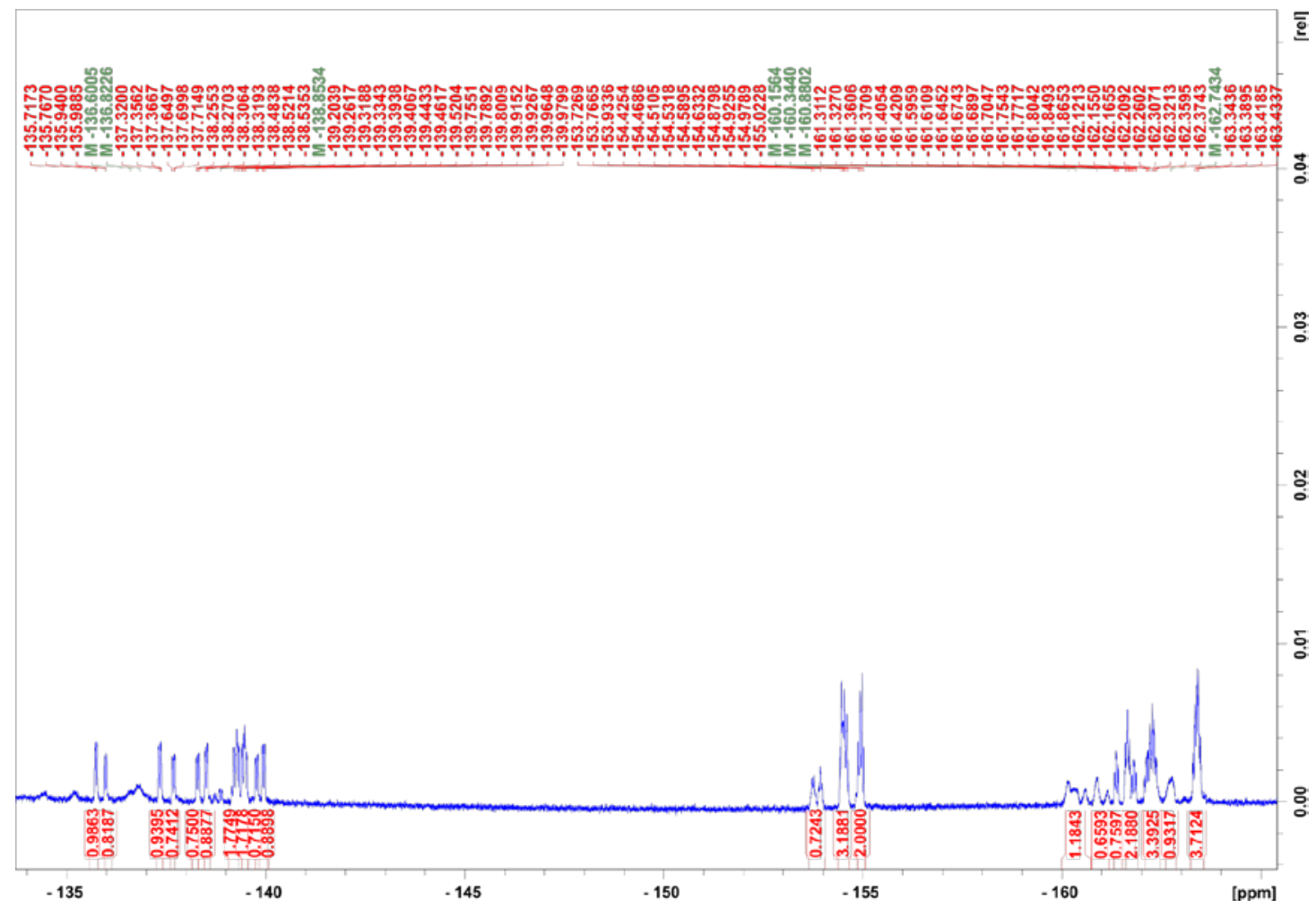

Fig. S83d ${ }^{19} \mathrm{~F} \quad$ NMR of 5-(Biphenylazo-4-methoxypyridine)-10,15,20-tris(pentafluorophenyl)nickel(II)chlorin 10b in Aceton- $\mathrm{d}_{6}+10 \mu \mathrm{L}$ TFA (mixture of syn and anti isomer (47:53)).

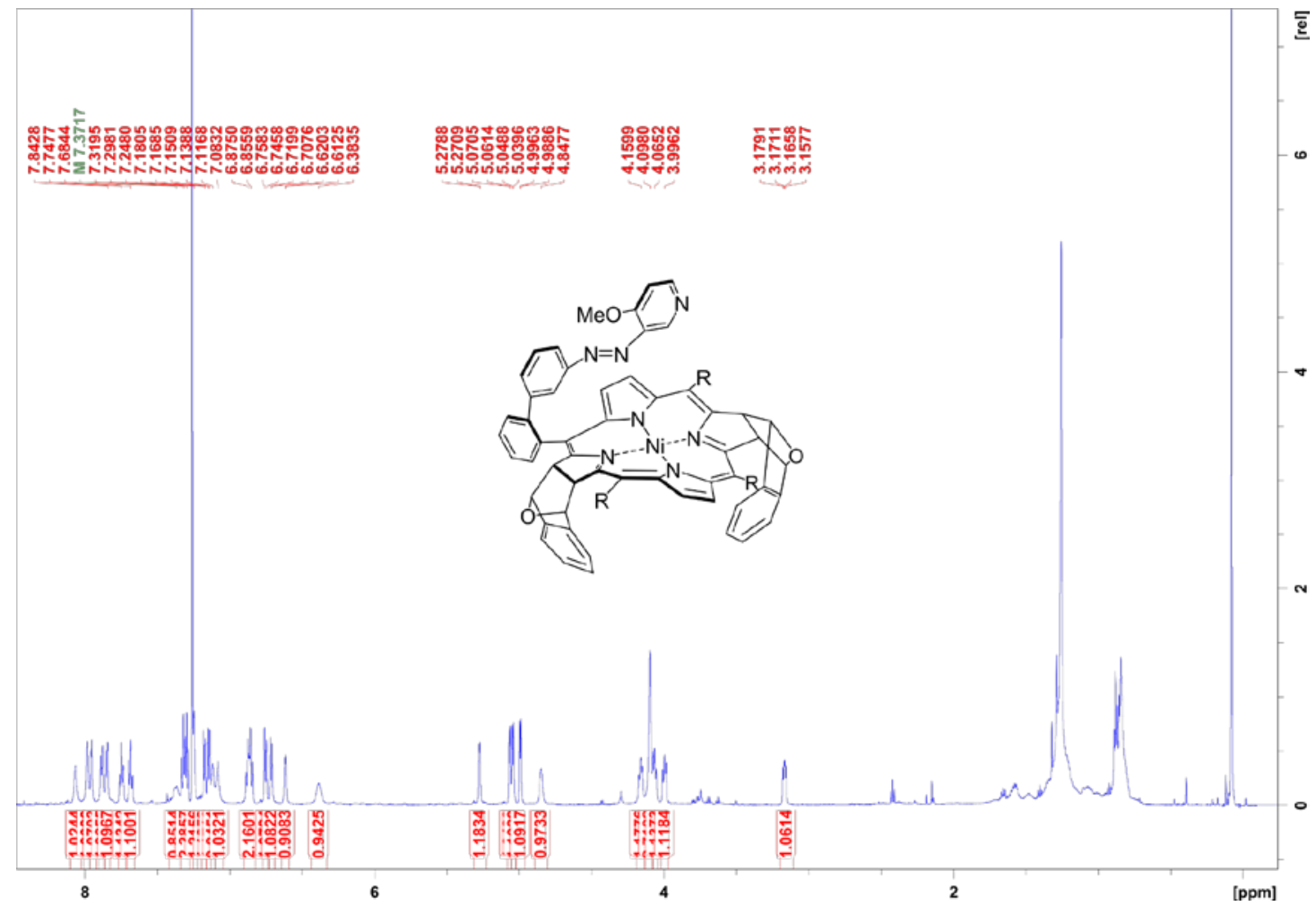

Fig. S84a $\quad{ }^{1} \mathrm{H} \quad$ NMR of $\quad$ 5-(Biphenylazo-4-methoxypyridine)-10,15,20-tris(pentafluorophenyl)nickel(II)bacteriochlorin 11 in $\mathrm{CDCl}_{3}+10 \mu \mathrm{L}$ TFA $\left(\mathrm{R}=\mathrm{C}_{6} \mathrm{~F}_{5}\right)$. 


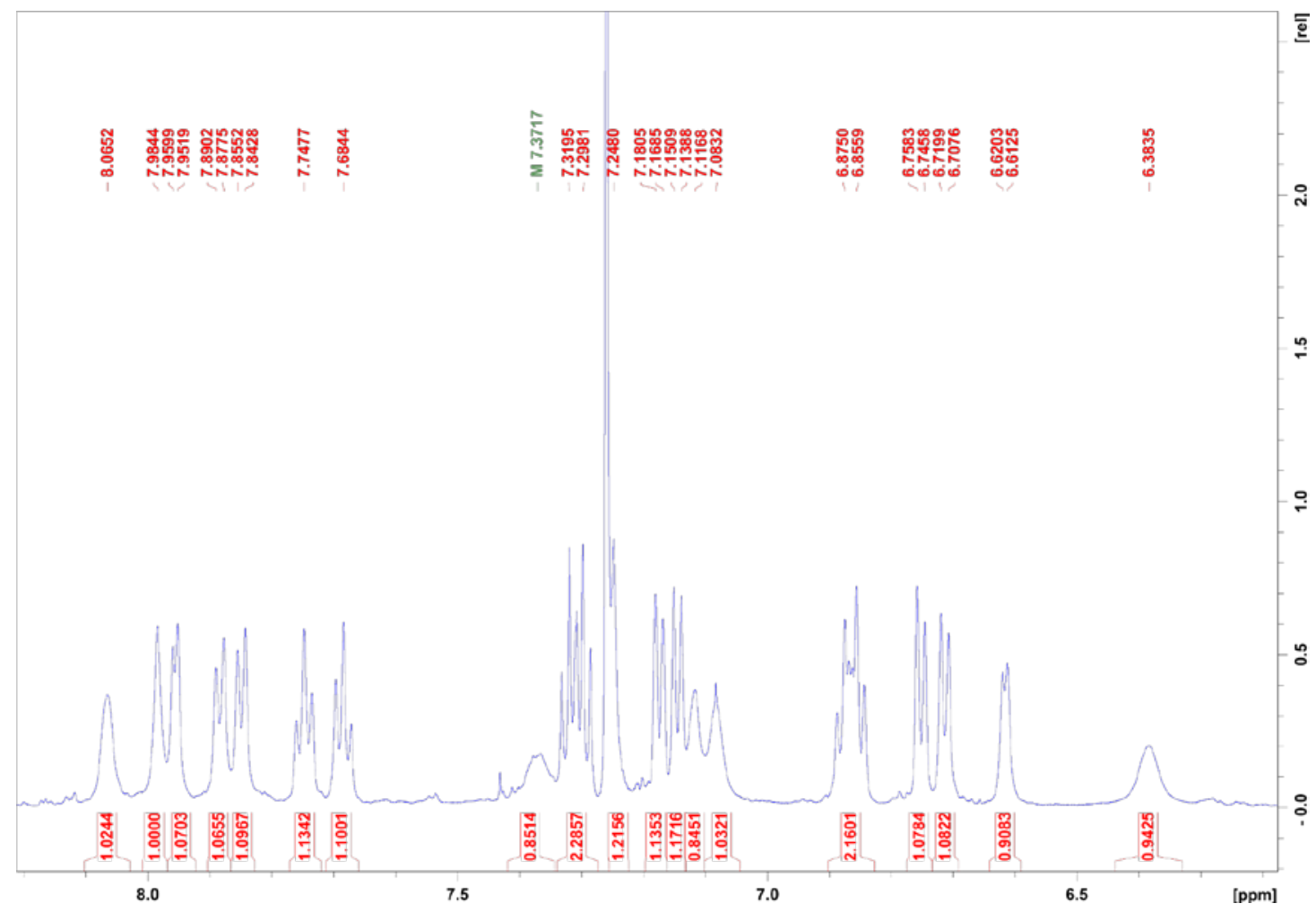

Fig. S84b Zoom of ${ }^{1} \mathrm{H}$ NMR of 5-(Biphenylazo-4-methoxypyridine)-10,15,20-tris(pentafluorophenyl)nickel(II)bacteriochlorin 11 in $\mathrm{CDCl}_{3}+10 \mu \mathrm{L}$ TFA $\left(\mathrm{R}=\mathrm{C}_{6} \mathrm{~F}_{5}\right)$.

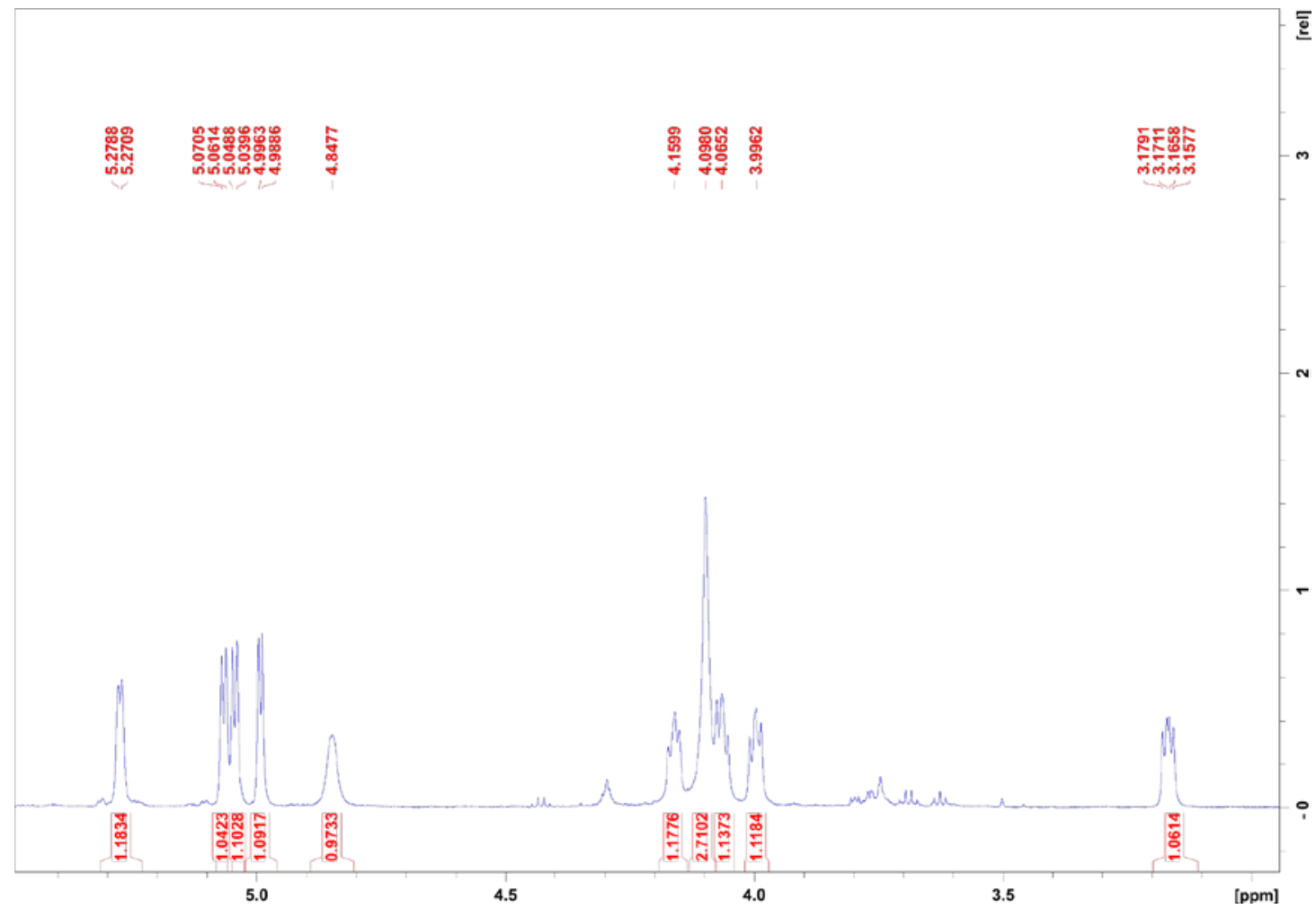

Fig. S84c Zoom of ${ }^{1} \mathrm{H}$ NMR of 5-(Biphenylazo-4-methoxypyridine)-10,15,20-tris(pentafluorophenyl)nickel(II)bacteriochlorin 11 in $\mathrm{CDCl}_{3}+10 \mu \mathrm{L}$ TFA $\left(\mathrm{R}=\mathrm{C}_{6} \mathrm{~F}_{5}\right)$. 


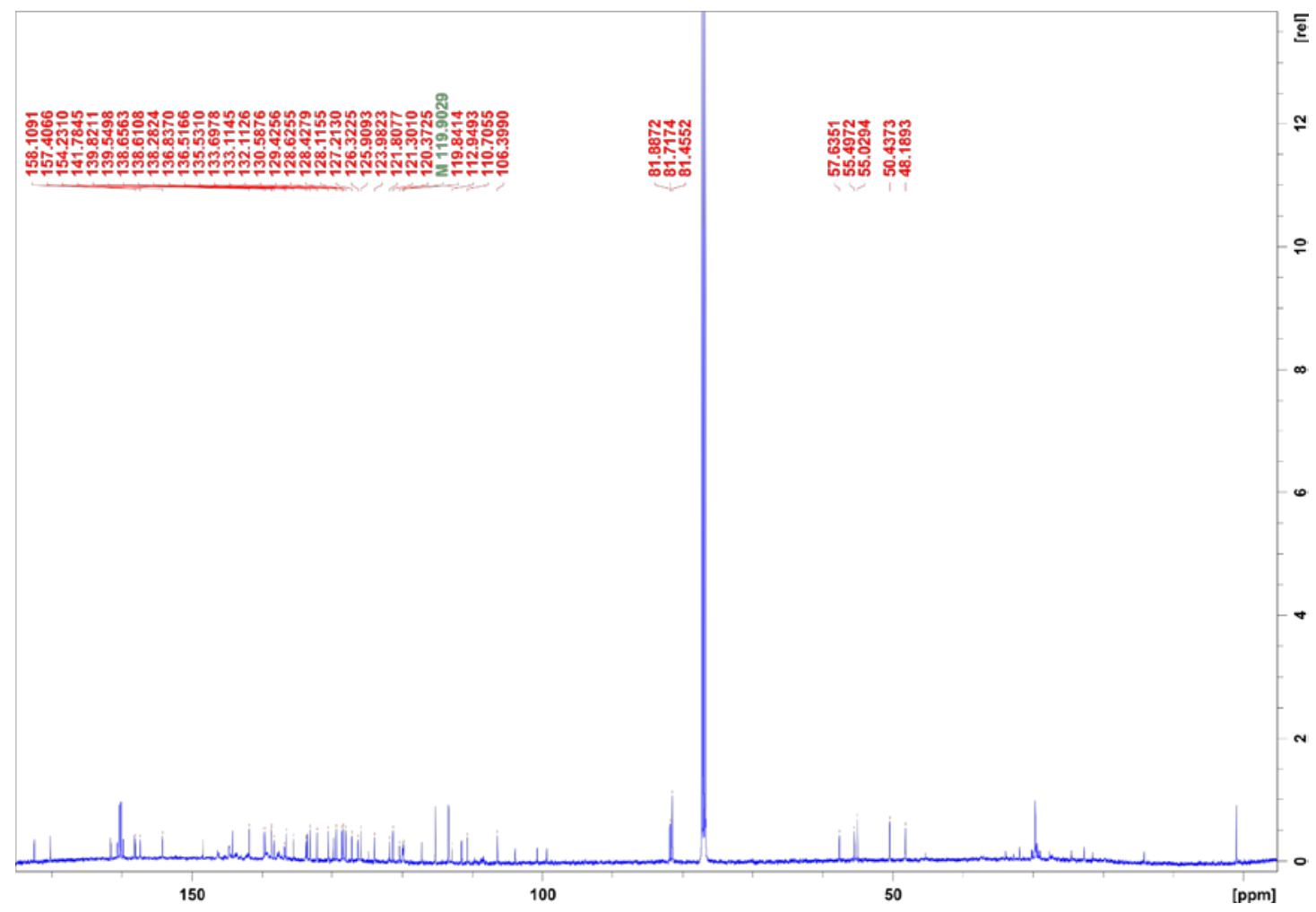

Fig. S84d ${ }^{13} \mathrm{C} \quad$ NMR of 5-(Biphenylazo-4-methoxypyridine)-10,15,20-tris(pentafluorophenyl)nickel(II)bacteriochlorin 11 in $\mathrm{CDCl}_{3}+10 \mu \mathrm{L}$ TFA.

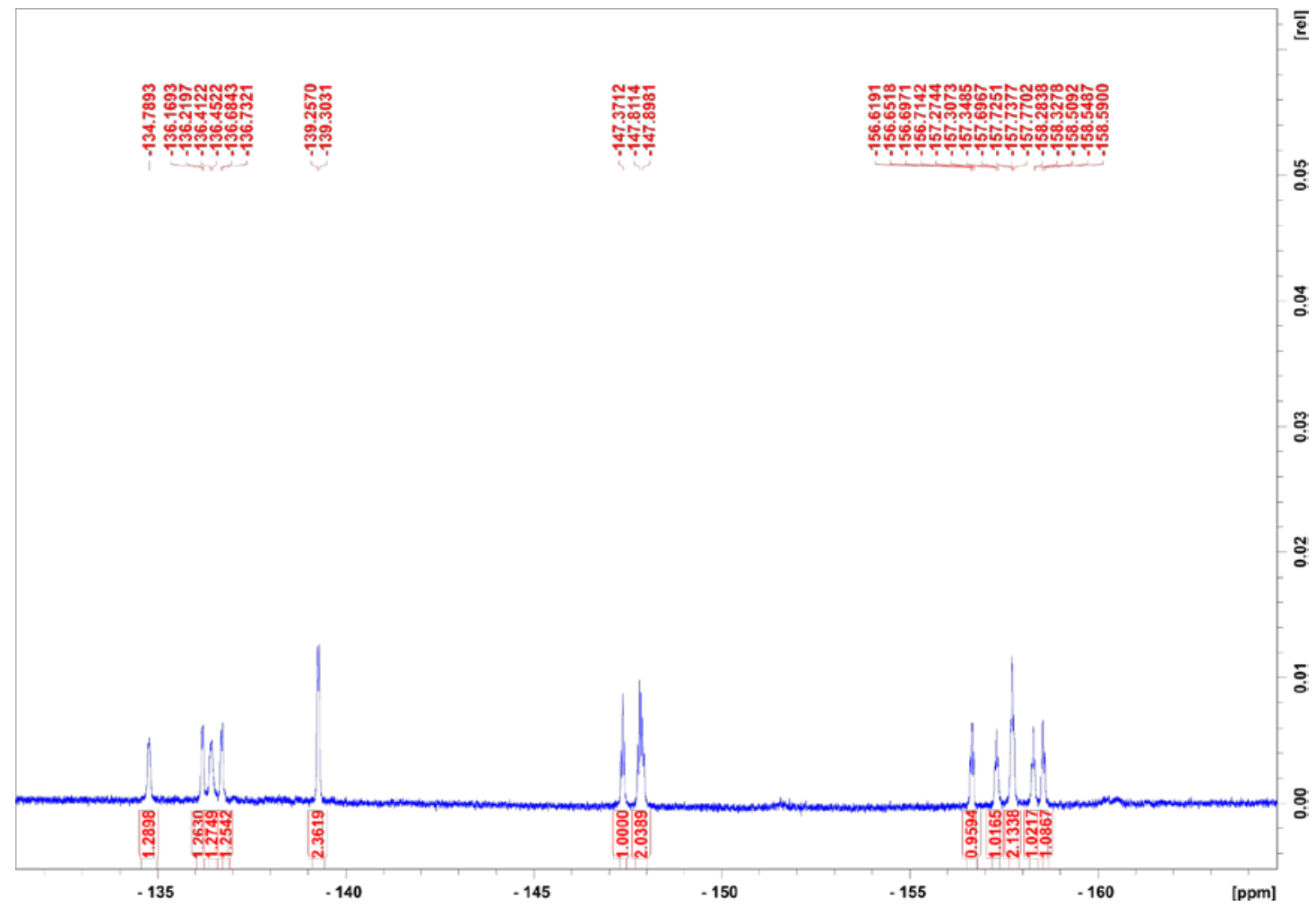

Fig. S84e $\quad{ }^{19} \mathrm{~F} \quad$ NMR of 5-(Biphenylazo-4-methoxypyridine)-10,15,20-tris(pentafluorophenyl)nickel(II)bacteriochlorin 11 in $\mathrm{CDCl}_{3}+10 \mu \mathrm{L}$ TFA. 


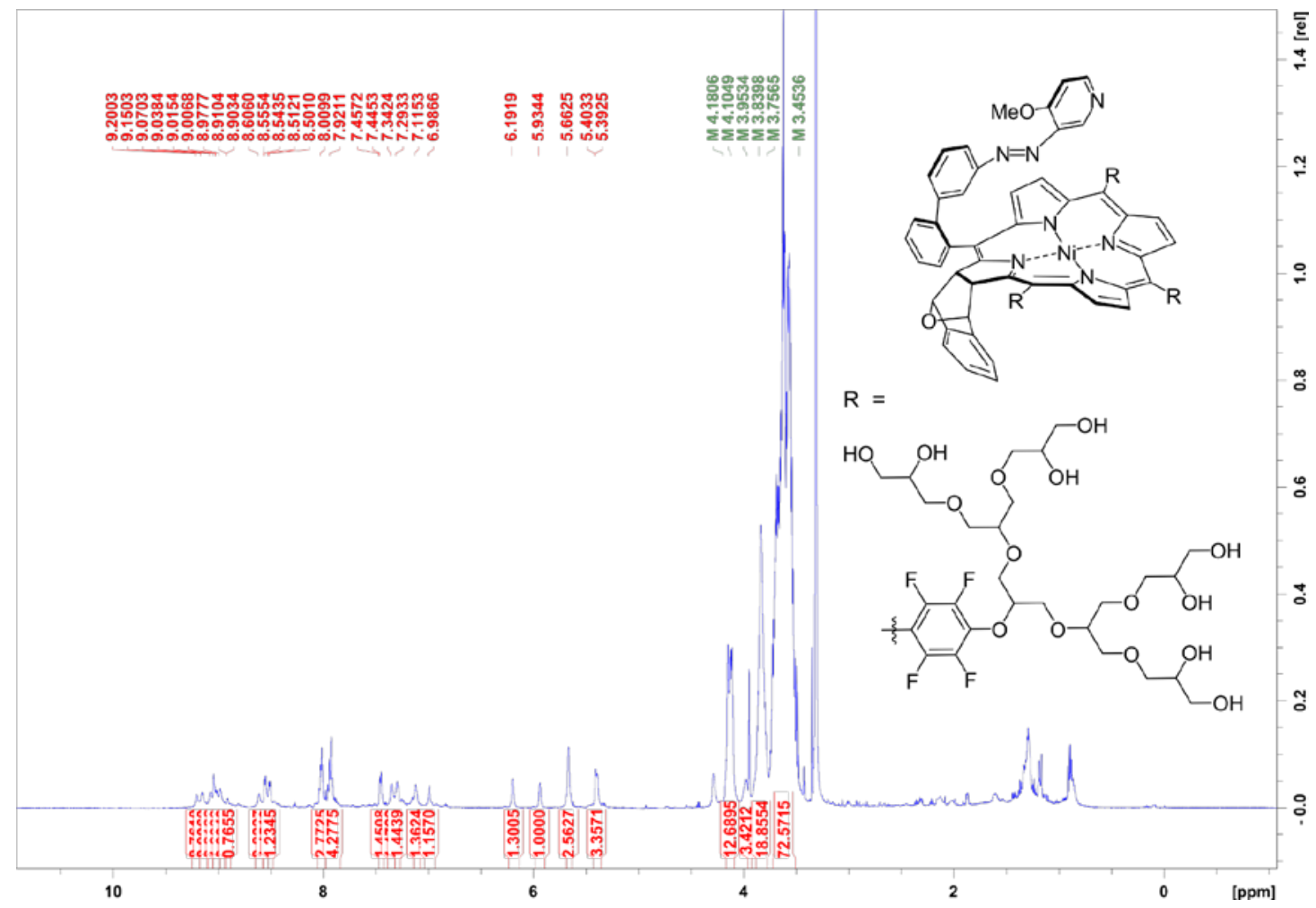

Fig. S85a ${ }^{1} \mathrm{H}$ NMR of dendronized chlorin RP 12a in MeOD $+20 \mu \mathrm{L}$ TFA.

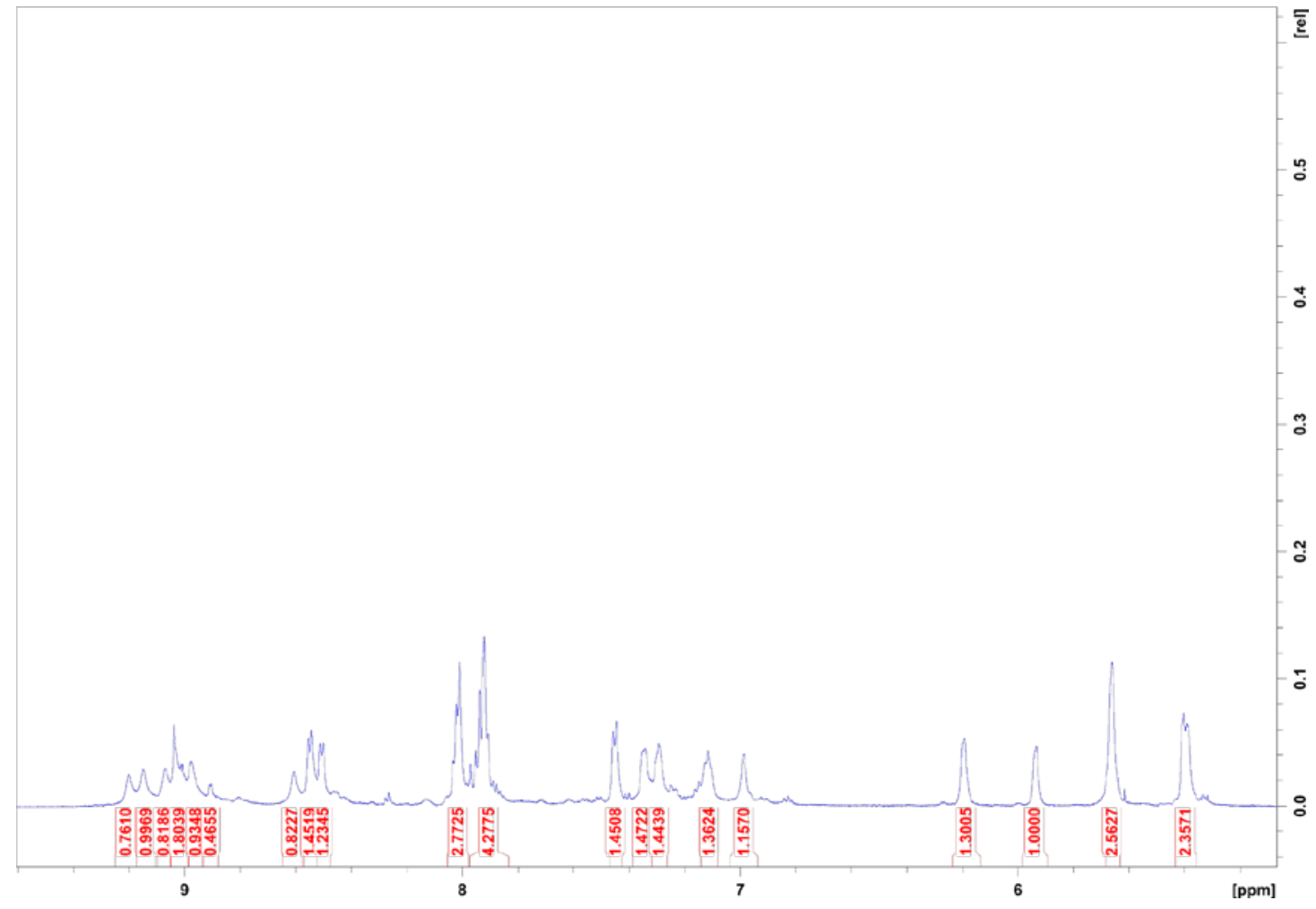

Fig. S85b Zoom of ${ }^{1} \mathrm{H}$ NMR of dendronized chlorin RP 12a in MeOD + $20 \mu \mathrm{L}$ TFA. 


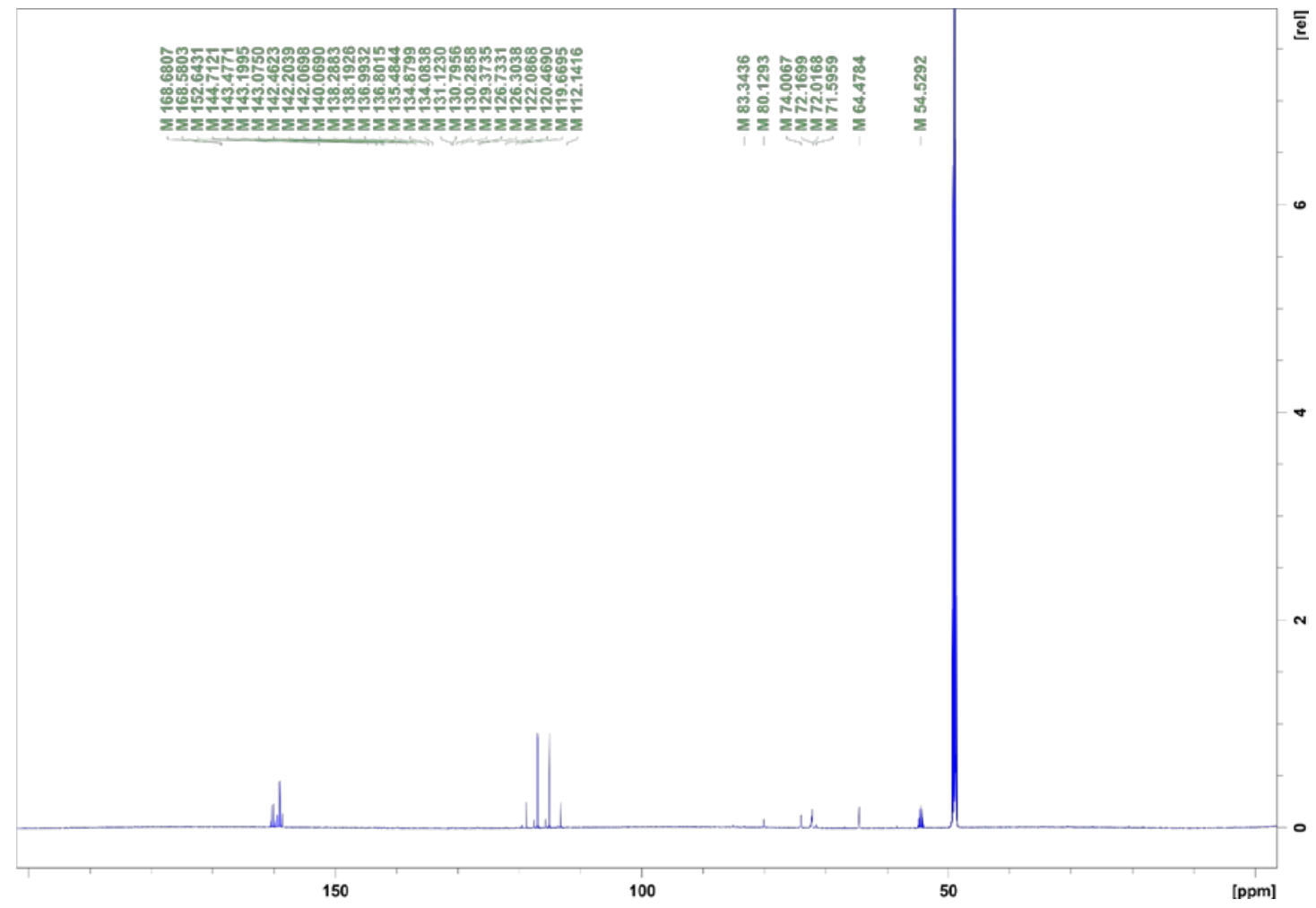

Fig. S85c ${ }^{13} \mathrm{C}$ NMR of dendronized chlorin RP 12a in MeOD + $20 \mu \mathrm{L}$ TFA.

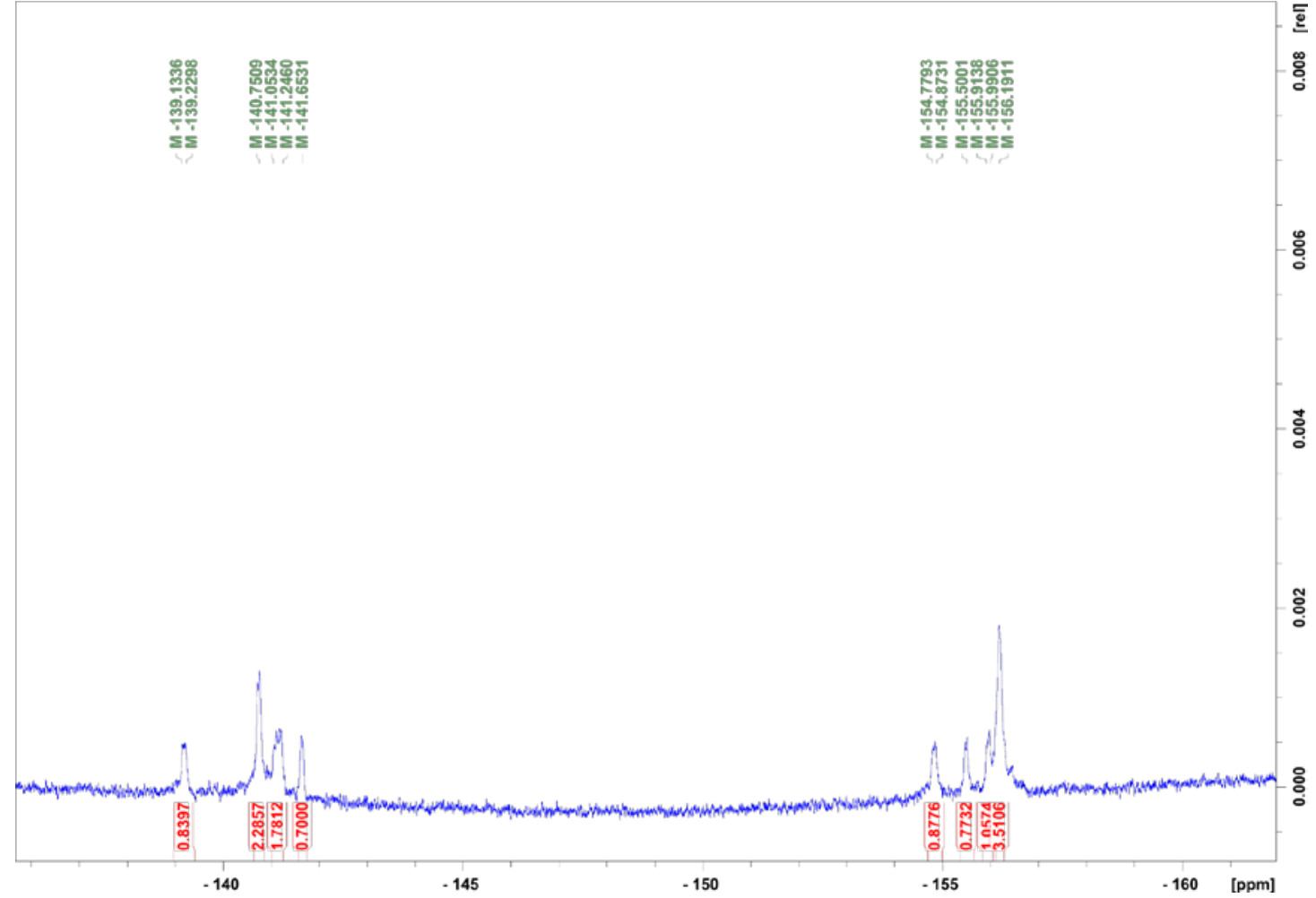

Fig. S85d ${ }^{19}$ F NMR of dendronized chlorin RP 12a in MeOD + $20 \mu \mathrm{L}$ TFA. 


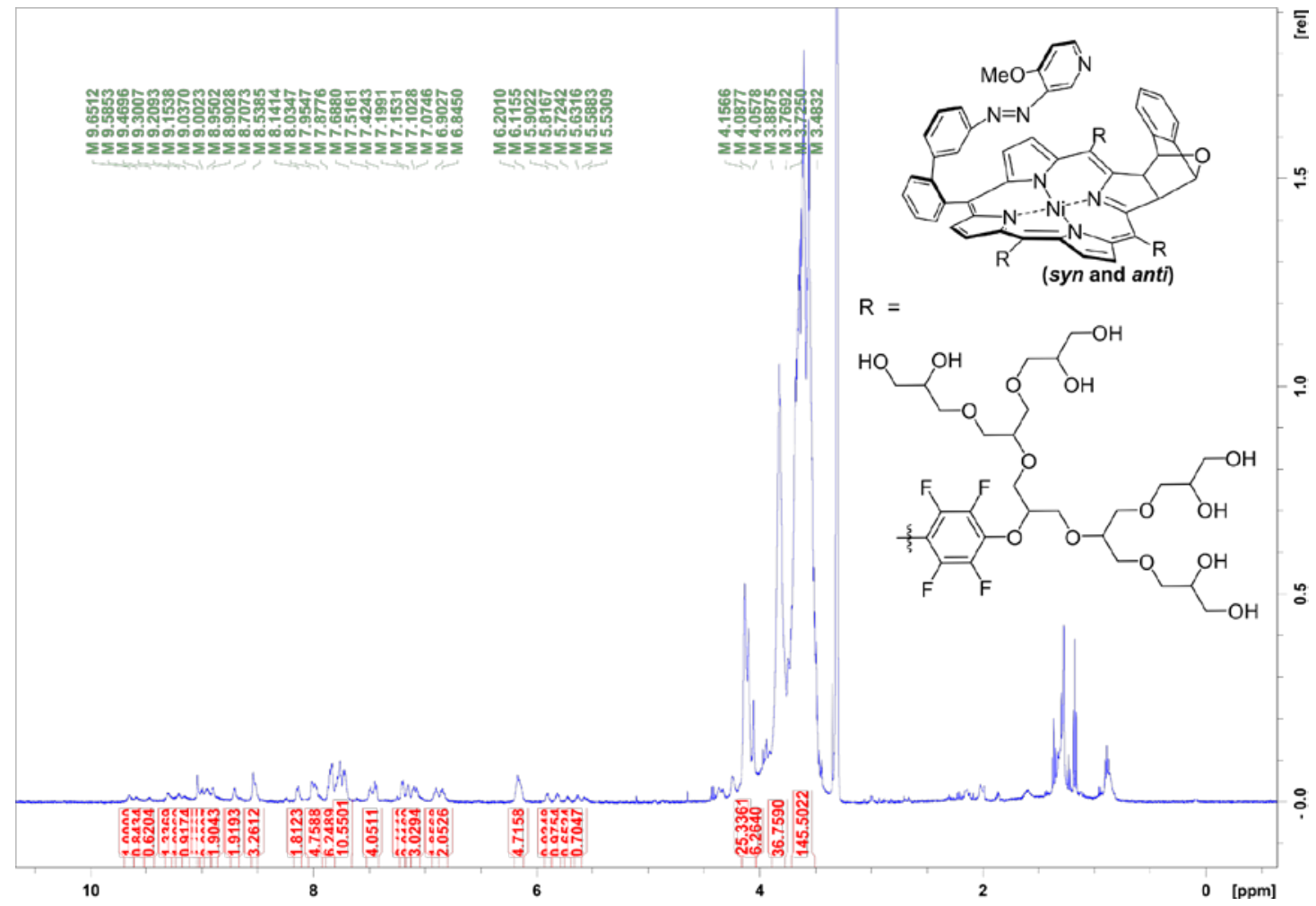

Fig. S186a ${ }^{1} \mathrm{H}$ NMR of dendronized chlorin RP 12b in MeOD $+20 \mu \mathrm{L}$ TFA.

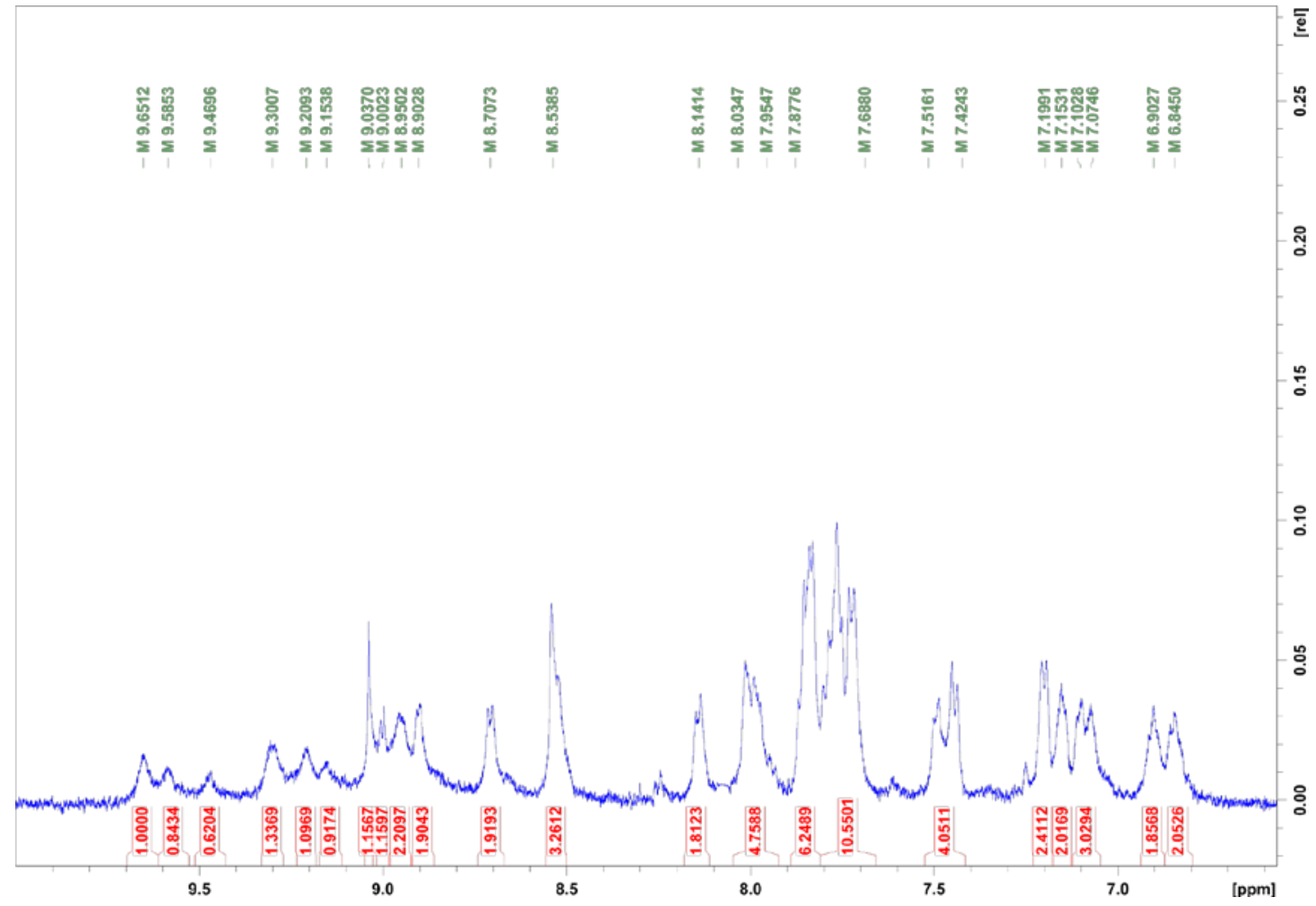

Fig. S186b Zoom of ${ }^{1} \mathrm{H}$ NMR of dendronized chlorin RP 12b in MeOD + $20 \mu \mathrm{L}$ TFA. 


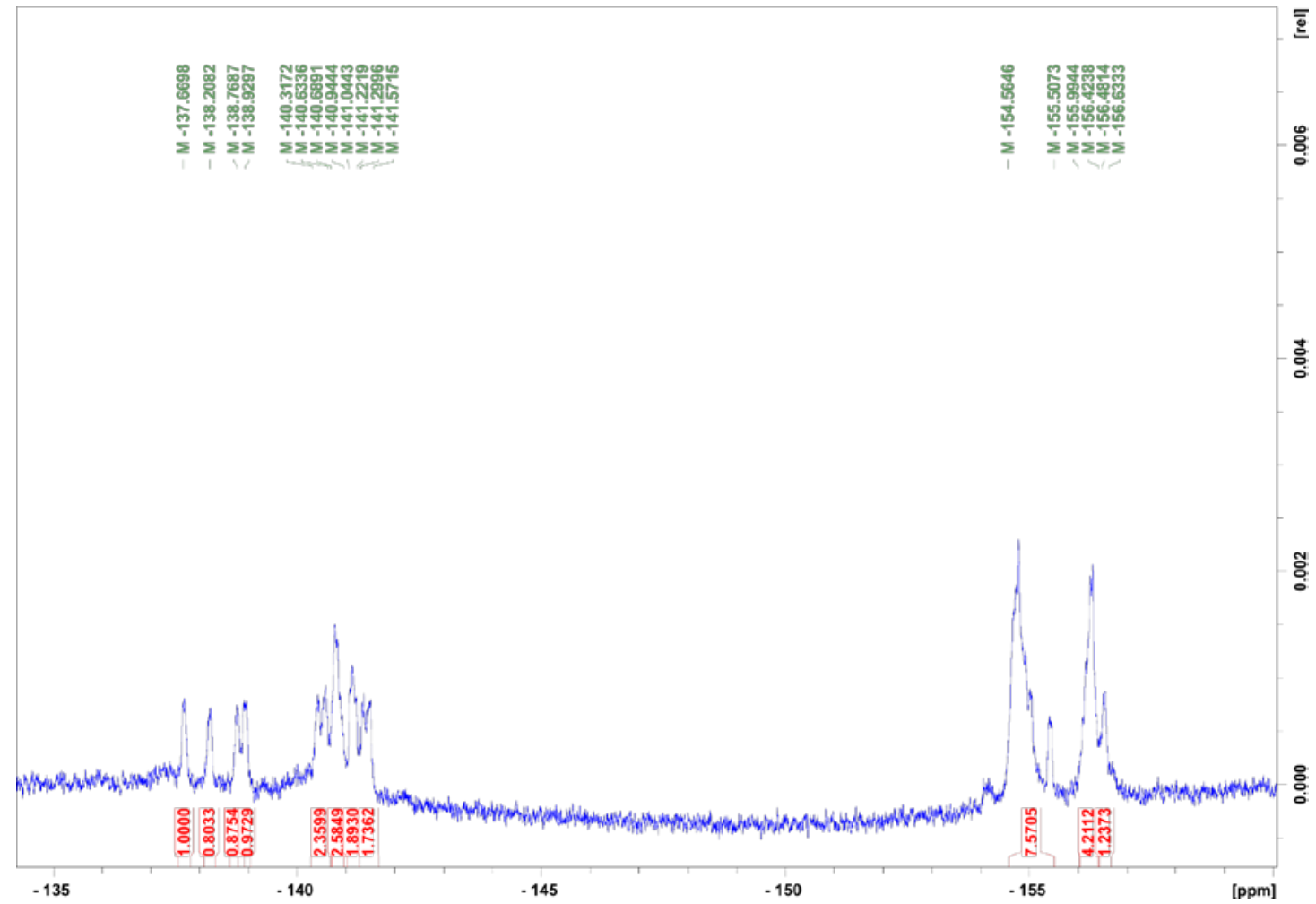

Fig. S86c ${ }^{19} \mathrm{~F}$ NMR of dendronized chlorin RP 12b in MeOD + $20 \mu \mathrm{L}$ TFA. 


\section{References}

(1) Peters, M. K.; Röhricht, F.; Näther, C.; Herges, R. One-Pot Approach to Chlorins, Isobacteriochlorins, Bacteriochlorins, and Pyrrocorphins. Org. Lett. 2018, 20, 7879.

(2) Heitmann, G.; Dommaschk, M.; Löw, R.; Herges, R. Modular Synthetic Route to Monofunctionalized Porphyrin Architectures. Org. Lett. 2016, 18, 5228.

(3) Peters, M. K.; Herges, R. Insertion of Ni(I) into Porphyrins at Room Temperature: Preparation of $\mathrm{Ni}(\mathrm{II})$ porphyrins, and $\mathrm{Ni}(\mathrm{II})$ chlorins and Observation of Hydroporphyrin Intermediates. Inorg. Chem. 2018, 57, 3177.

(4) Naito, K.; Rickborn, B. Isobenzofuran: new approaches from 1,3-dihydro-1methoxyisobenzofuran. J. Org. Chem. 1980, 45, 4061.

(5) Arendt, K. M.; Doyle, A. G. Dialkyl Ether Formation by Nickel-Catalyzed Cross-Coupling of Acetals and Aryl Iodides. Angew. Chem. Int. Ed. 2015, 54, 9876.

(6) Peters, M. K.; Herges, R. Preparation and isolation of isobenzofuran. Beilstein J. Org. Chem. 2017, 13, 2659.

(7) Dommaschk, M.; Peters, M.; Gutzeit, F.; Schütt, C.; Näther, C.; Sönnichsen, F. D.; Tiwari, S.; Riedel, C.; Boretius, S.; Herges, R. Photoswitchable Magnetic Resonance Imaging Contrast by Improved Light-Driven Coordination-Induced Spin State Switch. J. Am. Chem. Soc. 2015, 137, 7552.

(8) Wyszogrodzka, M.; Haag, R. A Convergent Approach to Biocompatible Polyglycerol "Click” Dendrons for the Synthesis of Modular Core-Shell Architectures and Their Transport Behavior. Chem. Eur. J. 2008, 14, 9202.

(9) Dommaschk, M.; Gröbner, J.; Wellm, V.; Hövener, J.-B.; Riedel, C.; Herges, R. Dendronised Ni(ii) porphyrins as photoswitchable contrast agents for MRI. Phys. Chem. Chem. Phys. 2019, 21, 24296.

(10) del Piero, S.; Melchior, A.; Polese, P.; Portanova, R.; Tolazzi, M. A Novel Multipurpose Excel Tool for Equilibrium Speciation Based on Newton-Raphson Method and on a Hybrid Genetic Algorithm. Ann. Chim. 2006, 96, 29.

(11) Dommaschk, M.; Thoms, V.; Schütt, C.; Näther, C.; Puttreddy, R.; Rissanen, K.; Herges, R. Coordination-Induced Spin-State Switching with Nickel Chlorin and Nickel Isobacteriochlorin. Inorg. Chem. 2015, 54, 9390. 